BRUNO COGLIATI

Participação das conexinas 43 e 32 no desenvolvimento da fibrose hepática: estudo em camundongos geneticamente modificados

São Paulo

2010 


\section{BRUNO COGLIATI}

\section{Participação das conexinas 43 e 32 no desenvolvimento da fibrose hepática:}

estudo em camundongos geneticamente modificados

Tese apresentada ao Programa de Pós-Graduação em Patologia Experimental e Comparada da Faculdade de Medicina Veterinária e Zootecnia da Universidade de São Paulo para obtenção do título de Doutor em Ciências

Departamento:

Patologia

Área de concentração:

Patologia Experimental e Comparada

\section{Orientador:}

Prof ${ }^{a}$ Dra. Maria Lúcia Zaidan Dagli

São Paulo 
Autorizo a reprodução parcial ou total desta obra, para fins acadêmicos, desde que citada a fonte.

DADOS INTERNACIONAIS DE CATALOGAÇÃO-NA-PUBLICAÇÃO

(Biblioteca Virginie Buff D’Ápice da Faculdade de Medicina Veterinária e Zootecnia da Universidade de São Paulo)

Participação das conexinas 43 e 32 no desenvolvimento da fibrose hepática: estudo em camundongos geneticamente modificados / Bruno Cogliati. -- 2010. 139 f. : il.

Tese (Doutorado) - Universidade de São Paulo. Faculdade de Medicina Veterinária e Zootecnia. Departamento de Patologia, São Paulo, 2010.

Programa de Pós-Graduação: Patologia Experimental e Comparada.

Área de concentração: Patologia Experimental e Comparada.

Orientador: Profa. Dra. Maria Lúcia Zaidan Dagli.

1. Comunicação intercelular. 2. Doenças hepáticas crônicas. 3. Fibrogênese hepática. 4. Fígado. 5. Células estreladas hepáticas. I. Título. 


\title{
UNIVERSIDADE DE SÃO PAULO \\ Faculdade de Medicina Veterinária e Zootecnia
}

\author{
Comissão Bioética
}

\section{CERTIFICADO}

Certificamos que o Projeto intitulado "Avaliação da influência das conexinas 32 e 43 na cirrose hepática induzida pela tiocetamida em camundongos", protocolo $\mathrm{n}^{\circ} 811 / 2005$, utilizando 180 (cento e oitenta) camundongos, sob a responsabilidade da Profa. Dra. Maria Lúcia Zaidan Dagli, está de acordo com os princípios éticos de experimentação animal da Comissão de Bioética da Faculdade de Medicina Veterinária e Zootecnia da Universidade de São Paulo e foi aprovado "ad referendun".

(We certify that the Research "Evaluation of connexins 32 and 43 influence on thioacetamide-induced hepatic cirrhosis in mice", protocol number 811/2005, under the responsibility of Profa. Dra. Maria Lúcia Zaidan Dagli, utilizing 180 (one hundred and eighty) mice, agree with Ethical Principles in Animal Research adopted by Bioethic Commission of the Faculty of Veterinary Medicine and Zootechny of University of São Paulo and was approved "ad referendun", meeting).

São Paulo, 02 de dezembro de 2005

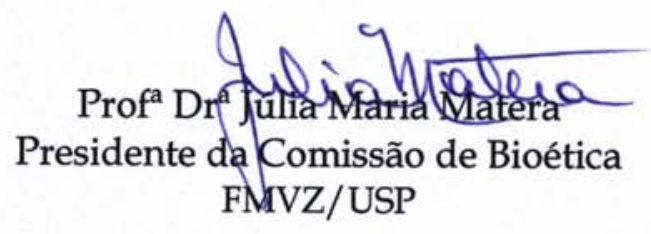

Av. Prof. Dr. Orlando Marques de Paiva, n 87 - 05508-270 - Cidade Universitária "Armando de Salles Oliveira". Fax: (11) 3032-2224 - fones: (11) 309107676/7671 - email: fmvz@edu.usp.br 


\section{FOLHA DE AVALIAÇÃO}

Nome: COGLIATI, Bruno

Título: Participação das conexinas 43 e 32 no desenvolvimento da fibrose hepática: estudo em camundongos geneticamente modificados

Tese apresentada ao Programa de Pós-Graduação em Patologia Experimental e Comparada da Faculdade de Medicina Veterinária e Zootecnia da Universidade de São Paulo para obtenção do título de Doutor em Ciências

Data:

Banca Examinadora

Prof. Dr.

Assinatura:

Instituição:

Julgamento:

Prof. Dr.

Assinatura:

Instituição:

Julgamento:

Prof. Dr.

Assinatura:

Instituição:

Julgamento:

Prof. Dr.

Assinatura:

Instituição:

Julgamento:

Prof. Dr.

Instituição:

Assinatura:

Julgamento: 


\section{DEDICATÓRIA}

À minha querida família

Por todo amor e apoio incondicional que sempre tiveram comigo

Hoje apenas sou o que sou, sei o que sei e sonho o que sonho,

Porque vocês permitiram que isso acontecesse

Aos meus pais Maria Aparecida de Lima Cogliati e Luiz Cogliati

Ao meu irmão Luciano Cogliati

À minha querida vó Neli

In Memorian de meus avós Renata e Ângelo Cogliati, meus avôs Nelson e Arnaldo, minha tia Letícia e meus bisavós Carolina e Najar 


\section{AGRADECIMENTOS ESPECIAIS}

À minha grande amiga e irmã Tereza, pela amizade incondicional em todos os momentos, pela alegria contagiante, senso de justiça, humildade e solidariedade sem precedentes. E por toda ajuda em meus dilemas profissionais e pessoais. Devo muito a você!

Ao meu fiel escudeiro e grande amigo Edson, por toda sua compreensão, disponibilidade, amizade e ajuda em todos os momentos. Obrigado por estar sempre presente e pelas alegrias constantes!

Ao grande amigo Thiago, por sua constante amizade, ajuda, alegria e disponibilidade, além de nossas aventuras acadêmico-científicas pelos congressos mundo afora.

À minha grande amiga Mirela, por sua doçura, amizade, serenidade e atenção, sempre disposta a tornar nossa estada na faculdade mais alegre e divertida.

À minha grande amiga Patrícia, que sempre pude confiar e contar em todos os momentos, sempre com muita atenção, alegria e entusiasmo.

Aos grandes amigos Lucas e Daniel, pela amizade, ajuda e longas discussões científicas que sempre me engrandeceram.

Aos meus eternos amigos de longa data Joyce, Daniel, Felipe e Daygo, por todos os nossos anos de convivência, alegrias e amizade incondicional. Muito obrigado a todos vocês pelo apoio, confiança e por fazerem parte de minha vida! 


\section{AGRADECIMENTOS}

À minha orientadora Prof ${ }^{a}$ Dra. Maria Lúcia Zaidan Dagli, pela oportunidade de trabalhar em seu laboratório e pela liberdade e confiança sempre depositada em mim.

Ao meu orientador da iniciação científica Prof ${ }^{0}$ Dr. Francisco Javier Hernandez Blazquez, por ter me aberto as portas ao maravilhoso mundo da pesquisa científica.

Ao grande entusiasta Prof ${ }^{\circ}$ Dr. Venâncio Avancini Ferreira Alves, por seu inimaginável apoio e participação em minha formação profissional como pesquisador e pensador científico. Seus desafios sempre me fizeram crescer e me tornaram um apaixonado pelo fígado.

Aos professores e alunos participantes da Reunião de Pesquisas em Andamento do Grupo de Fígado da Divisão de Anatomia Patológica do Hospital das Clínicas, por terem me recebido de maneira tão acolhedora e pelos ensinamentos que foram muito valiosos.

À Sociedade Brasileira de Hepatologia, pela oportunidade de participação no XX Congresso Brasileiro de Hepatologia e pelo importantíssimo prêmio jovem pesquisador "Luis Carlos Gayotto” concedido em reconhecimento a este trabalho.

Aos amigos da anatomia Elisângela, Fernanda, Camila, Tânia, Paula, Diogo, Alex, Maurício, Rose e Janaína, pelo companheiro e ajuda em diversos momentos.

Aos amigos Priscilla e Prof ${ }^{\circ}$ Nilson, do Departamento de Medicina Veterinária Preventiva, pelos ensinamentos durante meu estágio acadêmico, pela amizade, serenidade e grandes lições de vida e paz.

Aos colegas de laboratório Juliana, Tarso, Márcia, Marcelo, Krishna, Rafael, Kátia, pelos momentos que passamos juntos.

Aos amigos Luciana e Greg, pelas conversas e discussões sobre patologia hepática e ciência. 
Às queridas técnicas do laboratório Cyntia e Marguiti, por todos os ensinamentos, amizade e demonstrações de amor à vida.

À médica veterinária responsável pelo biotério Claudia Mori, pelos inestimáveis ensinamentos em relação ao manejo dos animais de laboratório.

Aos funcionários do biotério Herculano, Mauro, Rosiris e Idalina, pelo precioso auxílio no manejo com os camundongos.

Aos técnicos do laboratório de histopatologia do VPT Cláudio e Luciano, pela cordialidade e ensinamentos que sempre me dispensaram.

À querida técnica da microscopia eletrônica Shirlei, pela alegria e inestimável ajuda.

Às secretárias da Pós-Graduação Claúdia, Deise e Joana, por todo o auxílio oferecido.

Às secretárias do Departamento de Patologia Cris, Claúdia e Adriana, pelos auxílios e presença em todos os momentos.

Às bibliotecárias da FMVZ-USP pelo empenho e competência com os quais avaliaram este trabalho e pela amizade desde a época da graduação.

À Fundação de Amparo à Pesquisa do Estado de São Paulo (FAPESP), pelo apoio financeiro que permitiu a realização deste trabalho e minha formação profisssional.

À Faculdade de Medicina Veterinária e Zootecnia (USP), que permitiu minha formação acadêmica e profissional, da qual serei sempre grato e orgulhoso.

A todos que direta ou indiretamente auxiliaram na realização deste trabalho. 


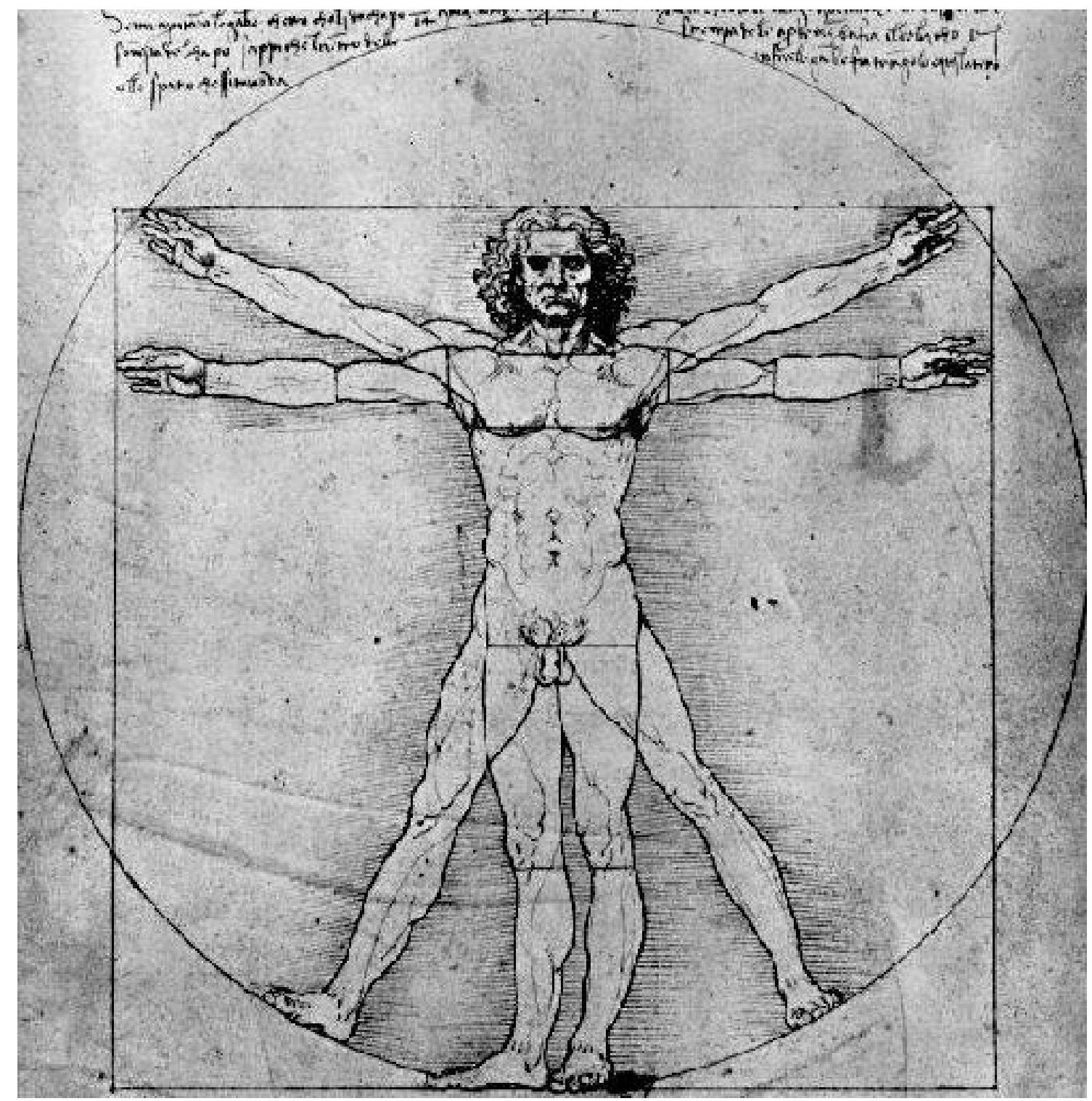

“Não é a experiência, a mãe de todas as artes e ciências, que engana as pessoas, mas, sim, a imaginação que lhes promete o que a experiência não lhes pode dar. A experiência é inocente; os nossos desejos vãos e insanos é que são criminosos. Distinguindo a mentira da verdade, a experiência nos ensina a perseverar em direção do que é possível, e não esperar, pela ignorância, atingir o que é inatingível, a fim de que não sejamos compelidos, vendo a nossa esperança por terra, a entregar-nos ao desespero.” 


\section{RESUMO}

COGLIATI, B. Participação das conexinas 43 e 32 no desenvolvimento da fibrose hepática: estudo em camundongos geneticamente modificados. [Role of connexins 43 and 32 on the development of hepatic fibrosis: a study in genetically modified mice]. 2010. $139 \mathrm{f}$. Tese (Doutorado em Ciências) - Faculdade de Medicina Veterinária e Zootecnia, Universidade de São Paulo, São Paulo, 2010.

A fibrose hepática resulta da cronicidade da injúria celular, ocasionando acúmulo dos componentes da matriz extracelular (MEC) pela ativação, principalmente, de células estreladas e fibroblastos portais em miofibroblastos. Estas células se conectam através de junções comunicantes do tipo gap, formadas por proteínas denominadas conexinas $(\mathrm{Cx})$. As junções gap são responsáveis pelo fluxo de moléculas e íons entre as células, desempenhando importante função no controle da homeostasia tecidual. Diversos tipos de conexinas foram descritas nas células hepáticas. Os hepatócitos expressam Cx32 e Cx26, enquanto as demais células não-parenquimatosas expressam Cx43. Alguns estudos analisaram a expressão das conexinas e das junções gap em processos de reparação e fibrogênese em diferentes tecidos, no entanto, poucos avaliaram seu papel na fibrogênese hepática. Sendo assim, o objetivo deste estudo foi avaliar os aspectos morfológicos, histopatológicos e moleculares da fibrose hepática, induzida por tetracloreto de carbono $\left(\mathrm{CCl}_{4}\right)$, em animais deficientes para as conexinas $43\left(\mathrm{Cx} 43^{+/-}\right)$ou $32\left(\mathrm{Cx} 32^{-/-}\right)$. Foram analisados dados biométricos, histopatológicos, ultra-estruturais, imuno-histoquímicos e bioquímicos, além da expressão gênica e protéica das conexinas. Os aspectos moleculares da fibrose hepática foram analisados pela expressão de genes relacionados com a deposição e degradação da matriz extracelular por PCR em tempo real. As análises macroscópicas e de varredura demonstraram um processo de micronodulação da superfície hepática mais acentuado nos camundongos $\mathrm{Cx} 43^{+/-}$fibróticos em relação aos animais wild-type $\left(\mathrm{Cx} 43^{+/+}\right)$fibróticos. Adicionalmente, estes animais apresentaram maior proporção volumétrica de colágeno no tecido hepático; redução na atividade necroinflamatória tecidual; redução nas concentrações séricas de AST e ALT; redução na proliferação celular dos hepatócitos e redução na expressão dos genes: colágeno tipo I, TGFß1, MMP-2, MMP-13 e TIMP-1. Por sua vez, os camundongos Cx32/- fibróticos apresentaram aumento na deposição de colágeno no parênquima hepático; aumento na atividade necroinflamatória tecidual e aumento nos níveis séricos das enzimas hepáticas AST, ALT e fosfatase alcalina em comparação aos animais wild-type $\left(\mathrm{C} \times 32^{+/+}\right)$fibróticos. Também foram 
observadas redução na proliferação hepatocelular e maior quantidade de corpúsculos apoptóticos no tecido hepático. Baseando-se em todos os resultados obtidos, observou-se que ambos os modelos animais apresentaram aumento da fibrose hepática, aparentemente ocasionada por diferentes modos de ação. Os animais deficientes em Cx43 apresentaram menor capacidade de degradação do colágeno, ocasionando seu acúmulo no tecido hepático. Por outro lado, os animais deficientes em Cx32 apresentaram maior deposição de colágeno em resposta à injúria hepatocelular mais acentuada, aliada ao desequilíbrio entre as taxas de proliferação celular e apoptose. Em conclusão, os resultados obtidos neste trabalho demonstraram a importante participação das conexinas no controle da fibrogênese hepática, e que podem representar potenciais alvos terapêuticos para o tratamento das doenças hepáticas crônicas em humanos e animais.

Palavras-chave: Comunicação intercelular. Doenças hepáticas crônicas. Fibrogênese hepática. Fígado. Células estreladas hepáticas. 


\begin{abstract}
COGLIATI, B. Role of connexins 43 and 32 on the development of hepatic fibrosis: a study in genetically modified mice. [Participação das conexinas 43 e 32 no desenvolvimento da fibrose hepática: estudo em camundongos geneticamente modificados]. 2010. $139 \mathrm{f}$. Tese (Doutorado em Ciências) - Faculdade de Medicina Veterinária e Zootecnia, Universidade de São Paulo, São Paulo, 2010.
\end{abstract}

Hepatic fibrosis results from chronic cell injury, leading to accumulation of components of extracellular matrix (ECM) through activation mainly of hepatic stellate cells and portal fibroblasts into myofibroblasts. These cells communicate through intercellular gap junctions composed of proteins known as connexins $(\mathrm{Cx})$. Gap junctions are responsible for the exchange of molecules and ions among cells, playing an important role in the control of tissue homeostasis. Several subtypes of connexins were described among hepatic cells. Hepatocytes express $\mathrm{Cx} 32$ and $\mathrm{Cx} 26$, while the other non-parenchymal cells express $\mathrm{Cx} 43$. Some studies analyzed the expression of connexins and gap junctions on processes of healing and fibrogenesis in different tissues; however, few studies evaluated its role on hepatic fibrogenesis. Thus, the objective of this study was to evaluate morphological, histopathological and molecular aspects of hepatic fibrosis induced by carbon tetrachloride $\left(\mathrm{CCl}_{4}\right)$ in animals with connexin $43\left(\mathrm{Cx}_{4} 3^{+/-}\right)$or $32\left(\mathrm{Cx} 32^{-/-}\right)$deficiency. We analyzed biometric, histopathological, ultrastructural, immunohistochemical and biochemical data, besides gene and protein expression of connexins. Molecular aspects of hepatic fibrosis were analyzed with the expression of genes related to deposition and degradation of extracellular matrix by real time PCR. Macroscopic and Scanning Electron Microscopy analyses showed a process of micronodulation of hepatic surface more accentuated on $\mathrm{Cx} 43^{+/}$fibrotic mice when compared to fibrotic wild-type $\left(\mathrm{Cx} 43^{+/+}\right)$animals. Additionally, these animals presented a higher collagen volumetric proportion on hepatic tissue; reduction of tissue necroinflammatory activity; reduction of serum AST and ALT; reduction of hepatocytes proliferation and reduction of expression type I collagen, TGF $\beta-1$, MMP-2, MMP-13 and TIMP-1 genes. Fibrotic Cx $32^{-/-}$mice presented an increase of collagen deposition in hepatic parenchyma; increase of tissue necro-inflammatory activity and increase of liver enzymes AST, ALT and alkaline phosphatase when compared to fibrotic wild-type $\left(\mathrm{C} \times 32^{+/+}\right)$animals. Reduction of hepatocellular proliferation and a higher amount of apoptotic bodies on hepatic tissue were also observed. Based on the results obtained, we observed that both animal 
models showed an increase of hepatic fibrosis, apparently caused by different modes of action. $\mathrm{Cx} 43$ deficient animals showed a reduced capacity to degrade collagen, causing its accumulation in the hepatic tissue. Cx32 deficient animals showed an increased collagen deposition in response to accentuated hepatocellular injury, together to an unbalance between rates of cellular proliferation and apoptosis. In conclusion, results obtained on this study demonstrate an important role of connexins on the control of hepatic fibrogenesis, which could represent potential therapeutical targets for the treatment of chronic liver diseases in humans and animals.

Key-words: Intercellular communication. Chronic liver diseases. Liver fibrogenesis. Liver. Hepatic stellate cells. 


\section{SUMÁRIO}

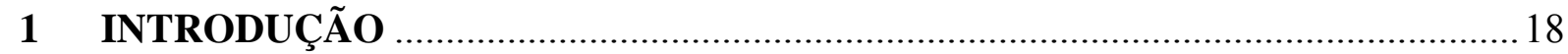

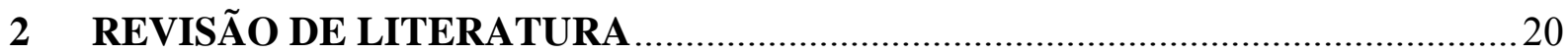

2.1 FIBROSE E DOENÇAS FIBROPROLIFERATIVAS: UMA VISÃO GERAL .............20

2.2 FIBROSE E CIRROSE HEPÁTICAS: DEFINIÇÃO E DADOS EPIDEMIOLÓGICOS ....22

2.3 ASPECTOS HISTOPATOLÓGICOS DAS HEPATITES CRÔNICAS .........................26

2.4 MECANISMOS DE FIBROGÊNESE HEPÁTICA ...................................................29

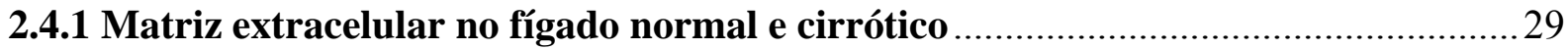

2.4.2 Células envolvidas na fibrogênese hepática .......................................................... 31

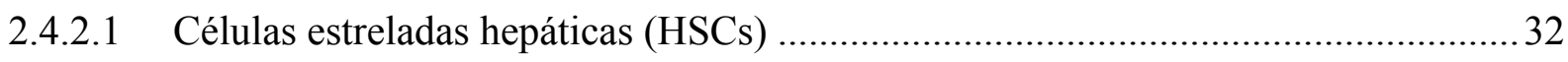

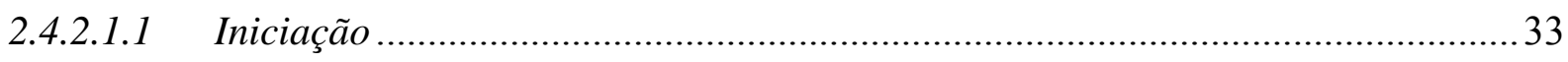

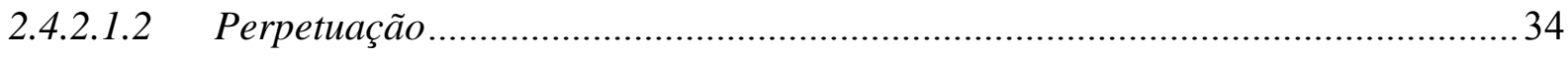

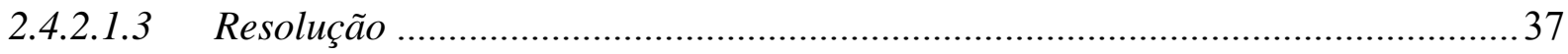

2.4.3 Degradação da matriz extracelular e resolução da fibrose .................................... 37

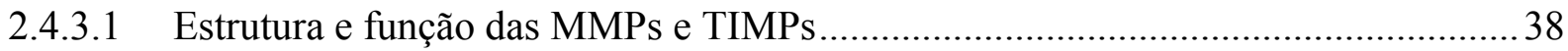

2.4.3.2 Mecanismos de fibrólise nas doenças hepáticas crônicas ...................................... 40

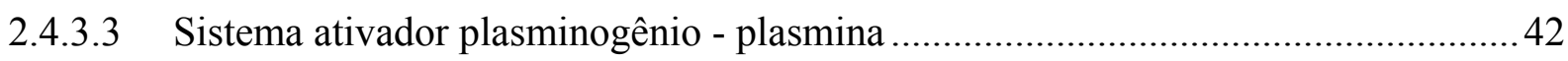

2.5 COMUNICAÇÃO INTERCELULAR E CONEXINAS ...............................................42

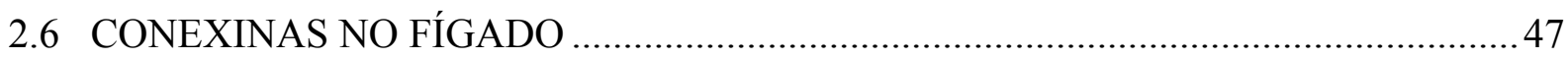

2.7 CONEXINAS NAS DOENÇAS HEPÁTICAS CRÔNICAS .......................................... 49

2.8 CONEXINAS E CÉLULAS ESTRELADAS HEPÁTICAS ......................................... 51

2.9 EXPRESSÃO DE CONEXINAS EM FIBROBLASTOS DÉRMICOS NA

CICATRIZAÇÃO E REPARAÇÃO TECIDUAL ......................................................... 52

2.10 EXPRESSÃO DE CONEXINAS EM FIBROBLASTOS NÃO-DÉRMICOS E OUTRAS

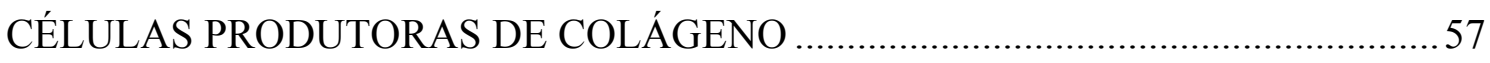

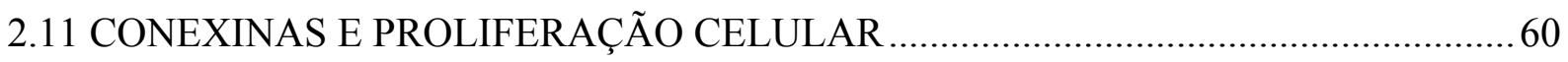

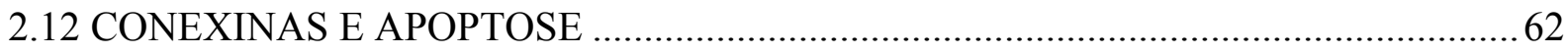

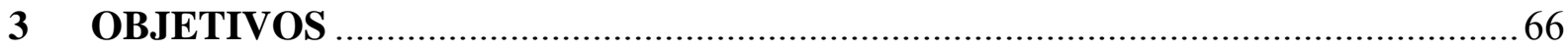

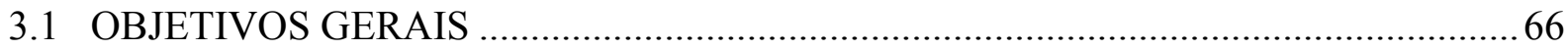

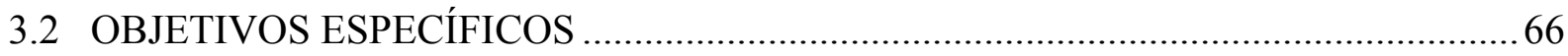

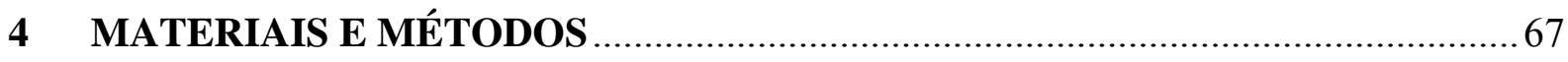

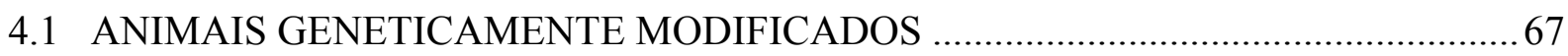


4.1.1 Camundongos deficientes em $\mathrm{Cx} 43\left(\mathrm{Cx}^{4} 3^{+/-}\right)$

4.1.2 Camundongos Knockout para $\mathrm{Cx} 32\left(\mathrm{Cx} 32^{-/-}\right)$.

4.2 CERTIFICADO DE BIOSSEGURANÇA E NORMAS PARA A MANUTENÇÃO E TRABALHOS COM ANIMAIS GENETICAMENTE MODIFICADOS 68

4.3 GENOTIPAGEM ...... 68

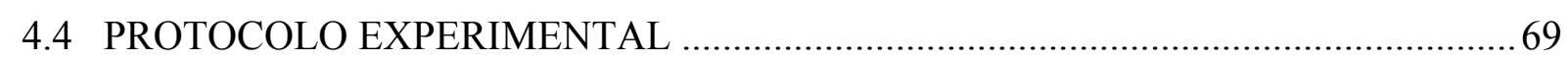

4.5 BIOMETRIA E ANÁLISE ANÁTOMOPATOLÓGICA …......................................... 70

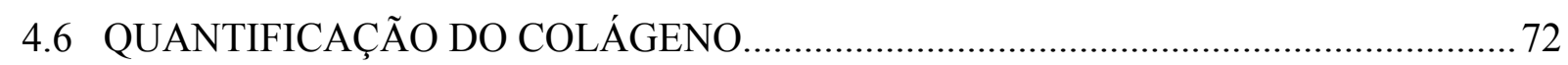

4.7 MICROSCOPIA ELETRÔNICA DE TRANSMISSÃO ................................................. 73

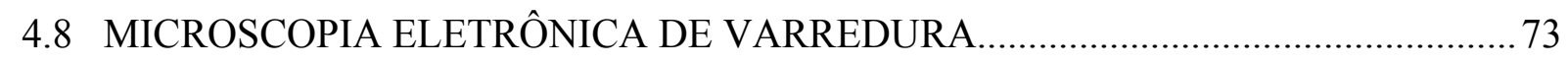

4.9 ANÁLISE BIOQUÍMICA DA FUNÇÃO HEPÁTICA................................................... 73

4.10 IMUNOFLUORESCÊNCIA PARA CONEXINAS E COLÁGENO TIPO I ................74

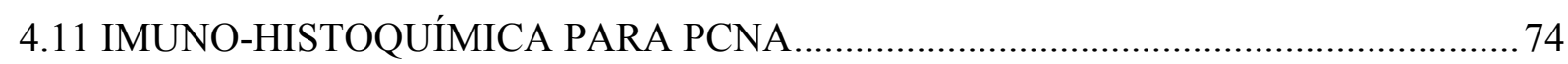

4.12 AVALIAÇÃO FUNCIONAL DA COMUNICAÇÃO INTERCELULAR PELA

TÉCNICA DE TRANSFERÊNCIA DE LUCIFER YELLOW (CUT-END) IN SITU .... 75

4.13 EXTRAÇÃO DE PROTEÍNAS E QUANTIFICAÇÃO................................................. 76

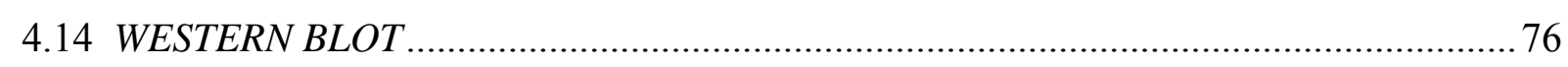

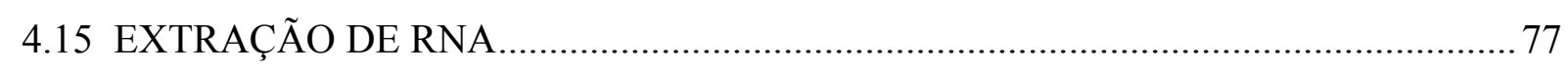

4.16 QUANTIFICAÇÃO E DETERMINAÇÃO DA INTEGRIDADE DO RNA TOTAL... 77

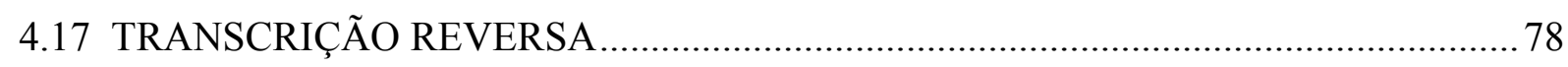

4.18 QUANTIFICAÇÃO DA EXPRESSÃO GÊNICA POR PCR EM TEMPO REAL ....... 78

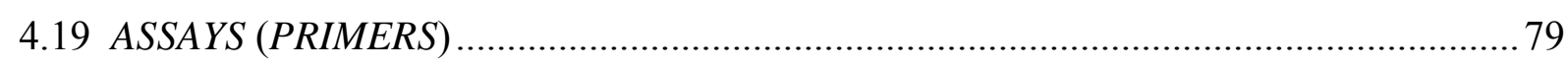

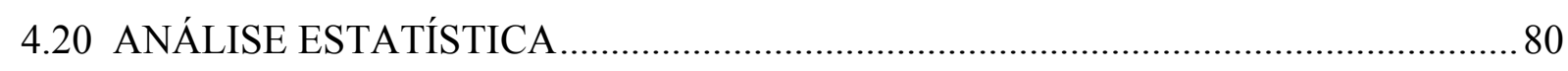

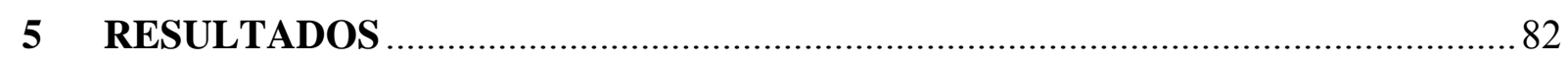

5.1 DEFICIÊNCIA DE Cx43 AUMENTA FIBROSE HEPÁTICA ....................................... 82

5.2 DEFICIÊNCIA DE Cx43 ATENUA A INJÚRIA HEPATOCELULAR .........................85

5.3 APENAS A Cx43 É ALTERADA NA FIBROSE HEPÁTICA MURINA ......................87

5.4 DEFICIÊNCIA DE Cx43 ALTERA OS MECANISMOS MOLECULARES RELACIONADOS À FIBROGÊNESE E FIBRÓLISE DA MEC HEPÁTICA ............. 91

5.5 AUSÊNCIA DE Cx32 AUMENTA DEPOSIÇÃO DE COLÁGENO ............................. 94

5.6 AUSÊNCIA DE Cx32 EXACERBA INJÚRIA HEPÁTICA E ALTERA BALANÇO ENTRE PROLIFERAÇÃO CELULAR E APOPTOSE ................................................. 98

5.5 AUSÊNCIA DE Cx32 REDUZ A COMUNICAÇÃO INTERCELULAR PELAS JUNÇÕES DO TIPO GAP. 


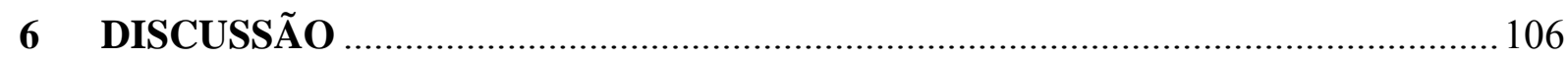

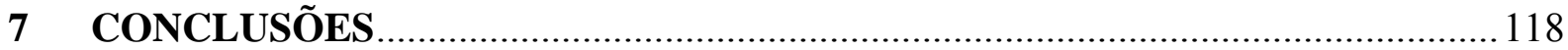

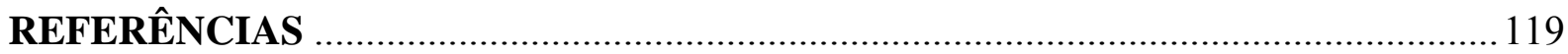




\section{INTRODUÇÃO}

“Quem não se comunica, se trumbica."

Esta famosa frase proferida pelo grande comunicador da televisão brasileira Chacrinha, entre as décadas de 50 e 80 , faz parte da cultura popular e resume perfeitamente a importância de uma comunicação efetiva nos diversos níveis sociais e interpessoais.

Desde a antiguidade, onde a comunicação era baseada em gestos e pinturas rupestres, o homem continua em uma constante busca por novas formas de comunicação. Este fervoroso instinto comunicativo relaciona-se diretamente à própria evolução da sociedade, seja por melhorias políticas, sociais ou econômicas. No entanto, sistemas de comunicação não são exclusividades dos seres humanos, como pode ser observado no complexo canto das baleias, no rígido controle existente em colméias e formigueiros ou ainda no ataque coordenado de leoas nas savanas africanas, entre outros milhares de exemplos. $O$ fato é: nenhuma sociedade progride ou se estabelece se não houver um sistema de comunicação eficiente, que seja capaz de transmitir informações e de se fazer entender pelos membros de um determinado grupo social. Seja ele qual for!

Agora faço uma provocação: seria possível esta mesma realidade ser verídica ao nível celular? Os tecidos animais podem ser considerados modelos de complexas sociedades, compostas por tipos celulares heterogêneos, que desempenham funções diversas e necessitam de um rígido controle para a manutenção da homeostasia tecidual. Estes 'indivíduos' celulares deflagram batalhas constantes contra os inimigos invasores, ou mesmo os próprios residentes enlouquecidos, que requerem uma refinada estratégia militar, utilizando todas as munições imunológicas, celulares e moleculares disponíveis. Nesse ínterim, muitos processos tornam-se interdependentes e necessitam de substâncias produzidas por células aliadas e pertencentes ou não à mesma sociedade. Sendo assim, estes sistemas necessitam de um rígido controle, sem possibilidade de barganhas ou falhas de comunicação, para se manterem funcionando e não sucumbirem.

Os símbolos utilizados na comunicação verbal ou escrita, por exemplo, são capturados por diversos sistemas sensoriais e são rapidamente decodificados e transformados em sinais químicos e/ou elétricos, sendo então compreendidos pelo órgãos responsáveis pela interpretação e análise dos dados. Ou seja, a comunicação direta entre os indivíduos representa apenas o início de uma complexa cascata de sinais celulares, sejam estes extra, intra ou intercelulares. Na comunicação humana, quando existe a necessidade de algum 
aparelho ou estrutura específica, como telefone ou internet, é denominada de comunicação mediada. Da mesma forma, a comunicação nas células depende de uma estrutura que as conecte formando canais, permitindo a transmissão de informações. Esta estrutura de mediação é formada por dois hemicanais ou conexons, que por sua vez são constituídos por proteínas chamadas conexinas. Assim, quando estes hemicanais se conectam, formam os canais comunicantes (gap junctions), permitindo o intercâmbio de moléculas e íons.

Entre todos os órgãos, o fígado apresenta uma destacada posição hierárquica devido sua enorme capacidade de realizar processos metabólicos e físiológicos. Neste contexto, diferentes células trabalham ativamente para que todos os processos sejam realizados no prazo pré-determinado, e para isso, necessitam de um sistema gerencial altamente 'conectado' para informar os feedbacks positivos e/ou negativos. Essa interação ocorre tanto nos hepatócitos, através da comunicação intercelular mediada por conexinas 32 e 26, quanto nas células não-parenquimatosas mediadas, principalmente, por conexina 43. Por outro lado, as alterações patológicas agudas ou crônicas que acometem o fígado promovem o desequilíbrio na expressão destas conexinas e, consequentemente, no sistema de comunicação celular. Com a falência do sistema de comunicação, a transmissão correta de informações aos membros envolvidos é prejudicada, e os 'indivíduos' celulares deixam de se entender.

A fibrose hepática representa uma das principais conseqüências da injúria crônica no fígado de humanos e animais, sendo ocasionada por diferentes etiologias. O controle da matriz extracelular no fígado normal pode ser comparado a um grande balé, onde as células atuam graciosamente na degradação e renovação dos diferentes componentes da matriz, em um ritmo lento e coordenado. Quando ocorre algum distúrbio, as cortinas se fecham, as luzes se apagam e um novo cenário contemporâneo, quase caótico, se instala no ambiente hepático. Começa uma revolução, com recrutamento e ativação de novas células guardiãs dos portais hepáticos, forma-se assim um exército, comandado por células estrelares e seus subalternos das destemidas regiões de Disse e redondezas. Soldados e generais atuam de forma conjunta no combate do inimigo, e principalmente, no reparo das instalações atingidas. Caso o inimigo não seja eliminado em tempo hábil, existem sérias possibilidades das forças aliadas sucumbirem, levando à morte e extinção total da vida hepática, restando apenas cicatrizes de guerra.

Agora, como em toda batalha, o sistema de comunicação efetiva entre generais e soldados é imprescindível para o avanço das tropas e a vitória final. Se a fibrose já se instala em um ambiente com comunicação prejudicada, como será seu desfecho na ausência ou diminuição das principais ferramentas responsáveis pela comunicação? 


\section{REVISÃO DE LITERATURA}

\subsection{FIBROSE E DOENÇAS FIBROPROLIFERATIVAS: UMA VISÃO GERAL}

Os mecanismos de reparação, cicatrização e remodelação tecidual são extremamente importantes para a manutenção da funcionalidade e integridade dos tecidos e órgãos após injúria celular. Por outro lado, a desregulação da cicatrização normal, aliada à continuidade do estímulo agressor, resulta na deposição excessiva de matriz extracelular (MEC). A fibrose é geralmente resultado final de um processo inflamatório crônico induzido por diversos estímulos, incluindo infecções persistentes, reações alérgicas ou auto-imunes, insultos químicos e injúria tecidual. Ainda, pode ser resultante de causas metabólicas, imunológicas, genéticas ou iatrogênicas As doenças fibroproliferativas incluem fibrose pulmonar, esclerose sistêmica, fibrose e cirrose hepática, doenças cardiovasculares, doença renal progressiva, degeneração macular, cicatrizes cutâneas hipertróficas e quelóides, dentre outras, e estão relacionadas a altas taxas de morbidade e mortalidade. Estima-se que $45 \%$ de todas as mortes registradas em países desenvolvidos sejam atribuídos a doenças crônicas fibroproliferativas (VARGAS; BRENNER; PHAN, 2005).

Apesar da diversidade de etiologias, existem muitas características celulares e moleculares em comum nas diferentes doenças crônicas. Na figura 1 estão descritos os principais eventos presentes no processo de reparação e cicatrização tecidual. A célula-chave mediadora do processo fibrogênico e comum em todas as doenças são os fibroblastos, que podem ser ativados em miofibroblastos, e são a fonte primária na produção de colágeno e outros componentes da MEC. Além dos fibroblastos, outras células participam da fibrogênese e podem dar origem aos miofibroblastos, como os fibrócitos circulantes derivados de célulastronco da medula óssea, células mesenquimais residentes ou ainda células endoteliais e epiteliais após sofrerem um processo conhecido como transição epitelial ou endotelialmesenquimal (VARGAS; BRENNER; PHAN, 2005; WYNN, 2007).

Em relação aos aspectos moleculares, as células epiteliais e/ou endoteliais liberam mediadores inflamatórios após injúria celular que iniciam a cascata antifibrinolíticacoagulativa. Nas fases seguintes de inflamação e proliferação, leucócitos são recrutados e ativados, iniciando a secreção de citocinas pró-fibróticas, tais como interleucina 13 (IL-13) e fator de crescimento transformador beta 1 (TGF $\beta-1)$. Células endoteliais, epiteliais e 
miofibroblastos estimulados no processo de reparação tecidual produzem metaloproteinases da matriz (MMPs), as quais rompem a membrana basal, além de produzirem outras citocinas e quimiocinas que recrutam neutrófilos, macrófagos, células $\mathrm{B}$ e $\mathrm{T}$ e eosinófilos. Os macrófagos e neutrófilos ativados removem os debris celulares e microrganismos invasores. Lentamente, após a fase inflamatória inicial, os miofibroblastos produzem componentes da MEC e células endoteliais formam novos vasos sanguíneos. Nas fases subseqüentes de remodelamento e maturação, os miofibroblastos ativados estimulam a contração da ferida, fibras colágenas começam a se organizar, vasos sanguíneos são restaurados e o tecido cicatricial é eliminado. Células epiteliais ou endoteliais dividem-se e migram sobre as camadas basais para regenerarem o epitélio ou endotélio, restaurando o dano tecidual até sua aparência normal. No entanto, em cicatrizes crônicas, o processo normal de cicatrização é interrompido: inflamação persistente, necrose tecidual e infecções promovem ativação crônica dos miofibroblastos e excessiva produção e deposição de MEC, formando uma cicatriz permanente (WYNN, 2007).

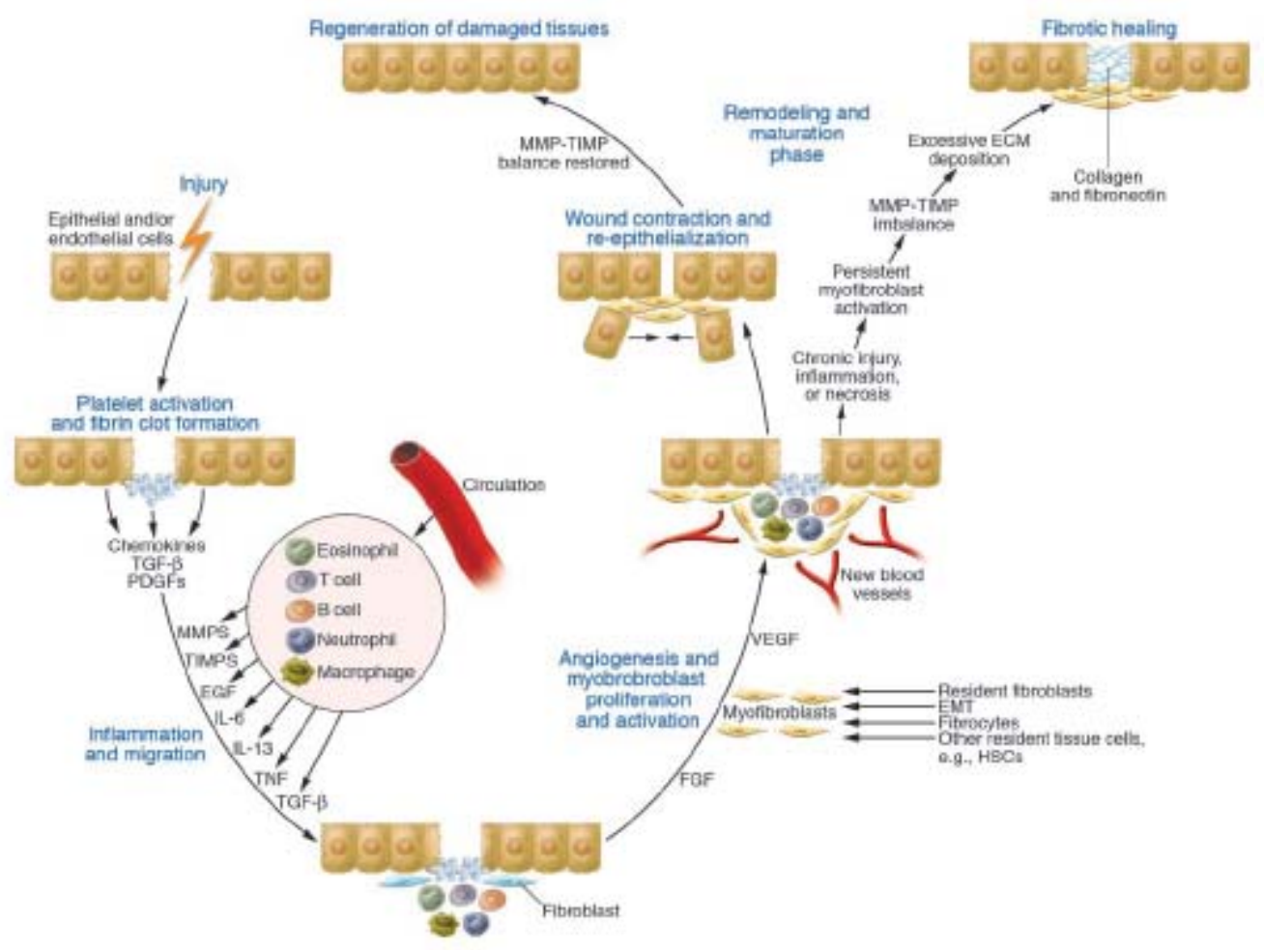

Fonte: (WYNN, 2007)

Figura 1 - Modelos dos mecanismos de reparação e cicatrização tecidual 
A participação dos fibroblastos na fibrogênese tecidual requer a modulação seqüencial de diversos comportamentos celulares, como migração, proliferação, síntese de matriz extracelular, remodelamento tecidual, transdiferenciação em miofibroblastos e finalmente apoptose. Estas células são ativadas por diversos estímulos, e necessitam de um complexo sistema de comunicação intercelular para que estes sinais sejam recebidos e transmitidos, evitando alterações patológicas no processo de reparação tecidual (ERLICH; DIEZ, 2003).

Atualmente, um dos maiores desafios na prática clínica está relacionado ao controle e regulação do processo fibrogênico, impedindo que ocorra uma excessiva deposição de matriz extracelular. Ao mesmo tempo, diversas terapias estão sendo investigadas em relação a sua capacidade de reverter um quadro de fibrose tecidual previamente instalado. No entanto, apesar do enorme impacto na saúde pública, ainda não existe um tratamento específico e eficaz para a fibrose. Sendo assim, a compreensão dos mecanismos celulares e moleculares envolvidos na fibrogênese tecidual representa uma importante ferramenta na busca de novas e eficientes terapias anti-fibróticas.

\subsection{FIBROSE E CIRROSE HEPÁTICAS: DEFINIÇÃO E DADOS EPIDEMIOLÓGICOS}

A doença hepática crônica é caracterizada como uma lesão persistente, de natureza inflamatória, associada a elevados níveis séricos das aminotransferases (AST e ALT) por mais de seis meses (SILVA, 2001). A cirrose é o resultado final de muitas destas doenças, que consiste em fibrose e regeneração nodular, e está intimamente relacionada ao desenvolvimento do carcinoma hepatocelular (CHC) (CRAWFORD, 2000).

Segundo estudos em autópsias, estima-se que entre 4,5 e 9,5\% da população mundial seja vítima da cirrose hepática e atualmente, é considerada a $14^{\mathrm{a}}$ causa de morte no mundo. No entanto, ainda existem algumas dificuldades para estabelecer a precisa incidência ou prevalência da cirrose hepática, principalmente devido seu desenvolvimento clínico silencioso e a ausência de marcadores não invasivos eficientes para screening populacional. Em 2001, a cirrose hepática foi considerada a sexta causa mais comum de morte em indivíduos adultos em países desenvolvidos, e a nona causa em países pobres ou em desenvolvimento (Figura 2) Mundialmente, estima-se que a cirrose representará a $12^{\mathrm{a}}$ causa de morte em 2020 (LIM; KIM, 2008). No Brasil, a cirrose foi responsável por cerca de 40 mil internações hospitalares no ano de 1997, demonstrando sua relevância na saúde pública (LIDA et al., 2005). 


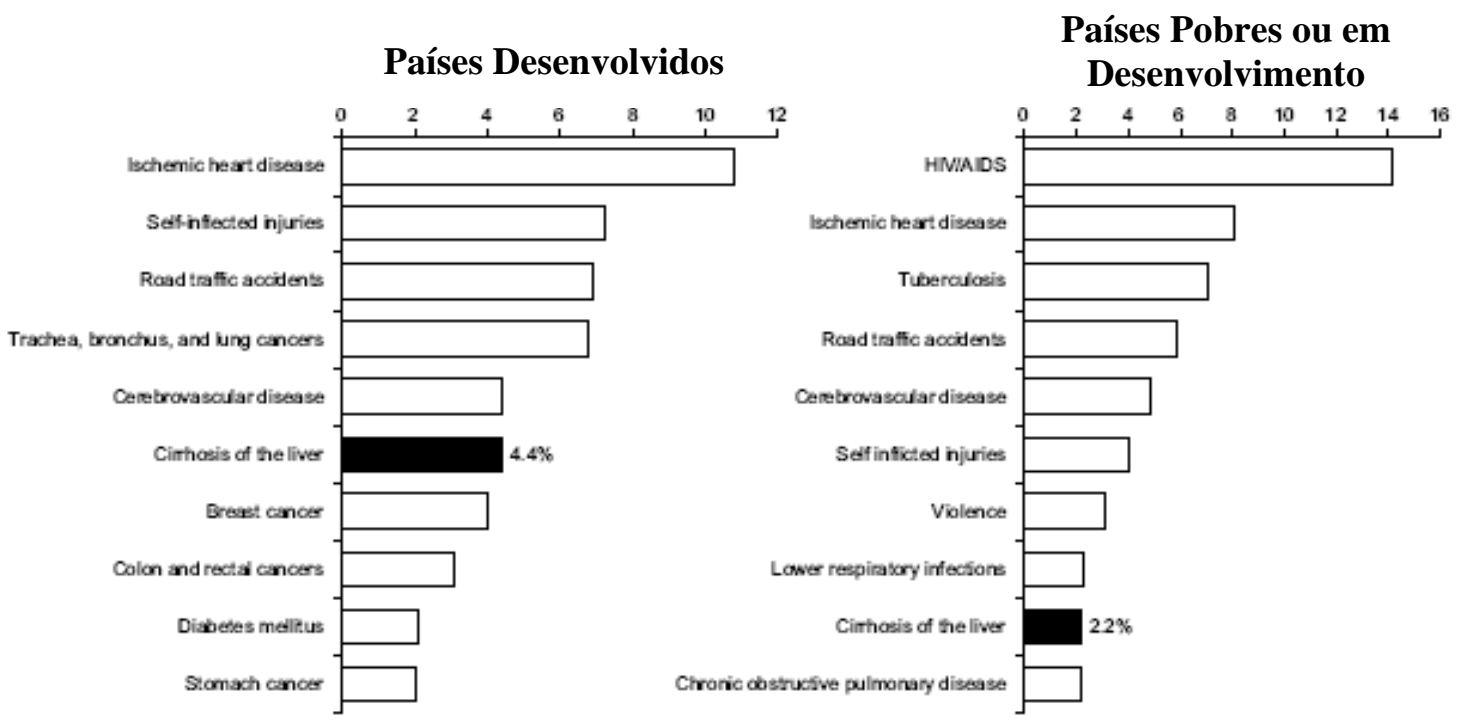

Fonte: (adaptado de LIM; KIM, 2008)

Figura 2 - Distribuição das principais causas de morte e prevalência da cirrose hepática (barra marcada em preto) em países desenvolvidos $\left(6^{\circ}\right.$ lugar $)$ e em países pobres ou em desenvolvimento $\left(9^{\circ}\right.$ lugar $)$

A etiologia da cirrose refere-se aos processos agressivos e contínuos de diversas naturezas, promovendo inflamação, necrose hepatocelular e reação de cicatrização crônica (CHEVILLE, 1999). De maneira geral, qualquer doença crônica no fígado pode ocasionar a fibrose e cirrose. Sendo assim, as principais causas estão relacionadas com infecções virais (vírus B e C), alcoolismo, hepatites imuno-mediadas, drogas hepatotóxicas, doenças colestáticas, anormalidades genéticas (hemocromatose, doença de Wilson e deficiência de $\alpha$ 1-antitripsina) e esteato-hepatite não-alcoólica (NASH) (LIM; KIM, 2008; LEFTON; ROSA; COHEN, 2009). A fibrose e cirrose hepáticas ocorrem nas diferentes regiões do mundo, independentemente da idade, sexo ou etnia, porém com algumas variações geográficas. Alcoolismo e infecção pelo vírus da hepatite C (VHC) são as causas mais comuns de cirrose nos países desenvolvidos, com atual crescimento na participação da esteato-hepatite nãoalcoólica devido a distúrbios do metabolismo relacionados à obesidade. Por outro lado, a infecção pelo vírus da hepatite B (VHB) é a causa prevalente em maior parte da Ásia e África subsariana (LIM; KIM, 2008; SCHUPPAN; AFDHAL, 2008; LEFTON; ROSA; COHEN, 2009). Na tabela 1 são apresentados dados da distribuição das hepatites crônicas em relação a sua etiologia, segundo estudo realizado em pacientes atendido no Hospital das Clinicas de São Paulo (SILVA, 2001). 
Tabela 1 - Distribuição das hepatites crônicas em pacientes atendido no Hospital das Clinicas de São Paulo. A grande maioria dos casos está relacionada com infecções virais

\begin{tabular}{ccc}
\hline Etiologia & $\mathbf{N}$ & $\mathbf{\%}$ \\
\hline Viral (VHB/VHC/VHD) & 281 & 78,5 \\
Hepatite auto-imune & 11 & 3,1 \\
Cirrose biliar primária & 11 & 3,1 \\
Colangite esclerosante primária & 3 & 0,8 \\
Cirrose criptogênica & 19 & 5,3 \\
Alcoólica & 14 & 3,9 \\
Drogas & 6 & 1,7 \\
Esteato-hepatite não-alcoólica & 13 & 3,6 \\
Doença de Wilson & 1 & 0,3 \\
\hline TOTAL & $\mathbf{3 5 8}$ & $\mathbf{1 0 0}$ \\
\hline
\end{tabular}

Fonte: (SILVA, 2001)

VHB (Vírus da Hepatite B); VHC (Vírus da Hepatite C); VHD (Vírus da Hepatite D). Cirrose criptogênica $=$ sem etiologia conhecida

$\mathrm{Na}$ medicina veterinária, a incidência da cirrose em cães e gatos não é bem estabelecida, porém relata-se que $15 \%$ das enfermidades hepáticas em cães sejam atribuídas a esta enfermidade (TWEDT, 1985). Corroborando estes dados, Sevelius (1995) considerou a cirrose como a manifestação mais comum entre as doenças inflamatórias crônicas no fígado de cães, apresentando maior taxa de mortalidade e pior prognóstico. Cavalos e suínos também são acometidos, porém em menor freqüência (SANTOS, 1986). Em gatos, as hepatites crônicas e cirrose são raramente observadas, ao contrário dos distúrbios colangiocelulares e de vesícula biliar (CULLEN, 2009).

A nomenclatura das hepatites crônicas em cães e gatos era baseada na classificação das doenças humanas e largamente utilizada pelos veterinários (DILL-MACKY, 1995; BOISCLAIR et al., 2001; CULLEN; MACLACHLAN, 2001). No entanto, recentemente foi publicado um livro pela Associação Mundial de Médicos Veterinários de Pequenos Animais (WSAVA), o qual normaliza a nomenclatura das doenças hepáticas em cães e gatos (CHARLES et al., 2006). Diversas causas foram descritas como causadoras das hepatites 
crônicas em cães, incluindo microrganismos, toxinas e drogas, reações imuno-mediadas e alterações metabólicas associadas a determinadas raças (FAVIER, 2009). Mas de maneira geral, o entendimento da etiologia das hepatites crônicas tem evoluído muito pouco nos últimos anos, sendo assim, a maioria dos casos na medicina veterinária permanecem como idiopáticos, sem tratamento específico e com prognóstico impreciso (WATSON, 2004).

A hepatite crônica associada a desordens metabólicas no metabolismo do cobre em cães é uma das causas mais estudadas nas últimas décadas (FAVIER, 2009). Em cães da raça Bedlington terrier, esta hepatite é muito bem descrita e está associada à deleção do exon 2 do gene COMMD1 (antigamente conhecido como MURR1), responsável pelo transporte do cobre. Outras raças caninas podem ser acometidas pelo acúmulo anormal de cobre, como por exemplo, as raças Dálmata, Doberman pinscher, Labrador, Skye terrier e West Highland white terrier (Figura 3). No entanto, não existe comprovação do envolvimento genético nestas raças. Esta hepatopatia canina encontra uma correspondente humana na doença de Wilson, a qual apresenta algumas diferenças como, por exemplo, o gene mutado e a sintomatologia clínica e laboratorial. Na doença de Wilson, a mutação ocorre no gene ATP7B, e ao contrário dos humanos, cães afetados pela hepatite por cobre não apresentam alterações nos níveis séricos de ceruloplasmina e $\mathrm{Cu}^{2+}$ ou alterações em outros órgãos (HOFFMANN, 2009).
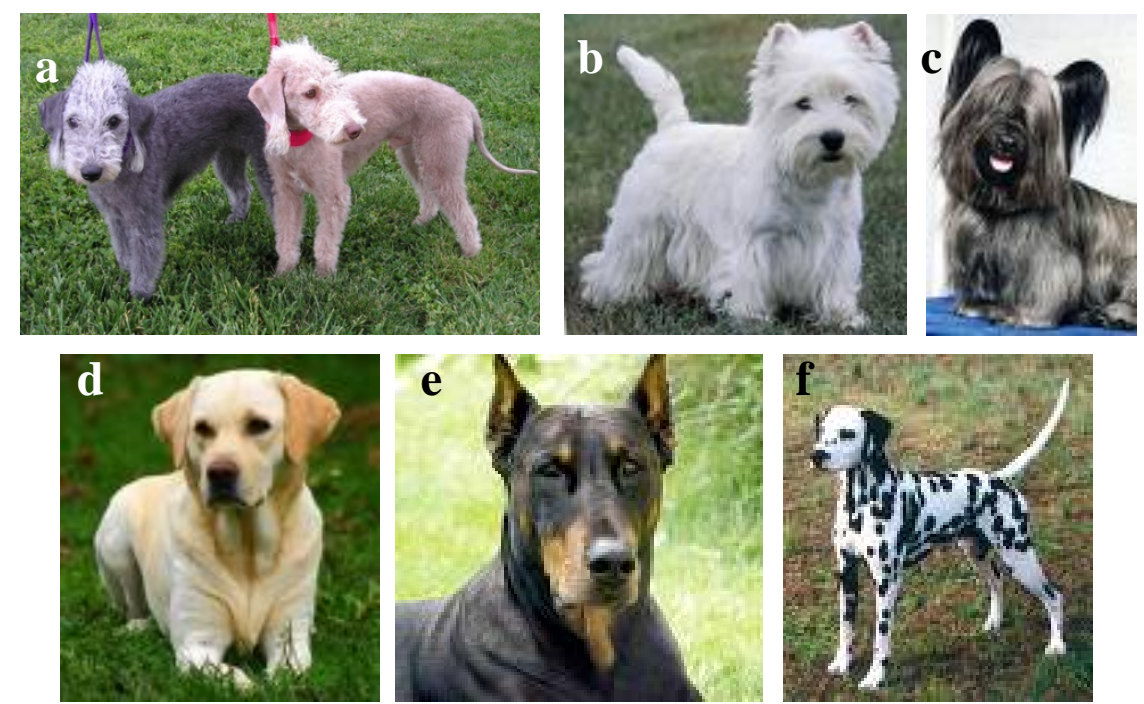

Figura 3 - Raças caninas acometidas pela hepatite associada ao acúmulo de cobre. a) Bedlington terrier, com conhecida mutação do gene COMMD1, responsável pelo transporte do cobre; b) West Highland white terrier; c) Skye terrier; d) Labrador; e) Doberman pinscher; f) Dálmata 


\subsection{ASPECTOS HISTOPATOLÓGICOS DAS HEPATITES CRÔNICAS}

O parâmetro básico para avaliação e classificação das hepatites crônicas baseia-se em seus aspectos anatomopatológicos. Sendo assim, a biopsia hepática ainda é considerada o "gold standard” no diagnóstico, assim como na avaliação prognóstica e monitoramento terapêutico das hepatites crônicas. O achado histológico mais importante presente no fígado é o infiltrado inflamatório, composto principalmente por linfócitos e variável quantidade de histiócitos e plasmócitos. A inflamação pode estar restrita aos espaços portais ou, como ocorre nas hepatites crônicas ativas, as células inflamatórias podem atacar os hepatócitos presentes na placa limitante. Esta atividade é conhecida como hepatite de interface e ocasiona a morte celular destes hepatócitos, também chamada de necrose em saca-bocados (piece meal necrosis). Ainda, podem ocorre focos inflamatórios dispersos no parênquima hepático. Juntamente com a inflamação, são observadas lesões parenquimatosas como tumefação e apoptose de hepatócitos, formando necroses focais ou extensas/em ponte (GAYOTTO; ALVES, 2001). Com a cronicidade da agressão hepática, ocorre a ativação das células estreladas e fibroblastos em miofibroblastos, promovendo intensa deposição de colágeno nos espaços periportais ou/e perissinusoidais (BATALLER; BRENNER, 2001; FRIEDMAN, 2000, 2003).

A fibrose resulta da perpetuação anormal do processo de reparação e cicatrização tecidual após injúria hepática crônica. Nesse contexto, a cirrose é considerada o estágio avançado da fibrose hepática, resultando na doença do fígado 'terminal' (SCHUPPAN; AFDHAL, 2008). Modificações na arquitetura histológica hepática caracterizam o processo patológico da cirrose, com formação de nódulos regenerativos circundados por extensas faixas de tecido conjuntivo (Figura 4A) (CRAWFORD, 2000).

No início do processo fibrogênico ocorre deposição de colágeno promovendo uma expansão fibrosa ao redor dos espaços porta, os quais formam septos fibrosos (Figura 4B) que os unem entre si (septos porta-porta). Com a cronicidade do processo, também ocorre formação de septos fibrosos ligando os espaços porta e as veias centrolobulares (septos portacentro). E dependendo da etiologia, também é possível a formação de septos ligando as veias centrolobulares (septos centro-centro) (Figura 4B). Os diferentes padrões de fibrose hepática indicam a presença de mecanismos específicos para as diferentes etiologias das doenças hepáticas crônicas (DI BONZO et al., 2009) Em algumas doenças, como na esteato-hepatite não-alcoólica em humanos ou na hepatite lobular dissecante em cães, a deposição de colágeno 
ocorre preferencialmente nos espaços perissinusoidais, caracterizando a fibrose pericelular (GAYOTTO, 2001; CULLEN; MACLACHLAN, 2001; CULLEN, 2009).

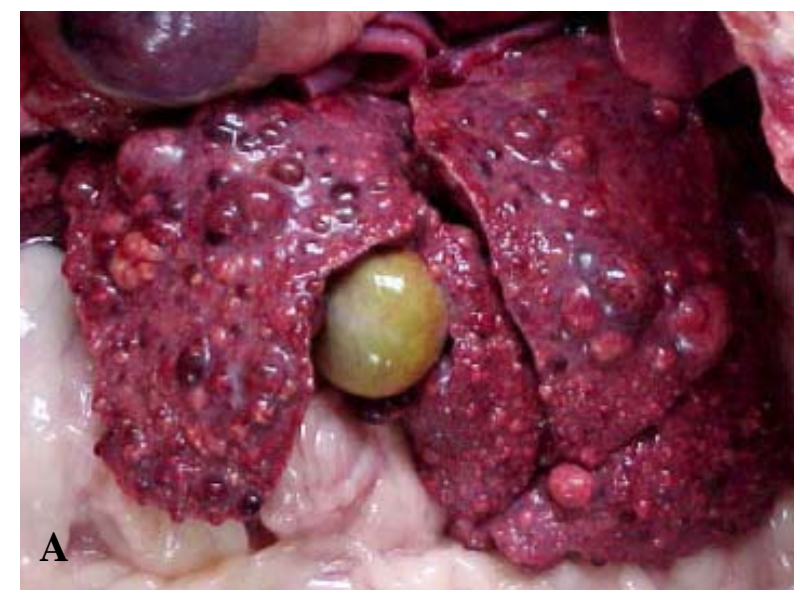

Fonte: (CULLEN; MACLACHLAN, 2001)

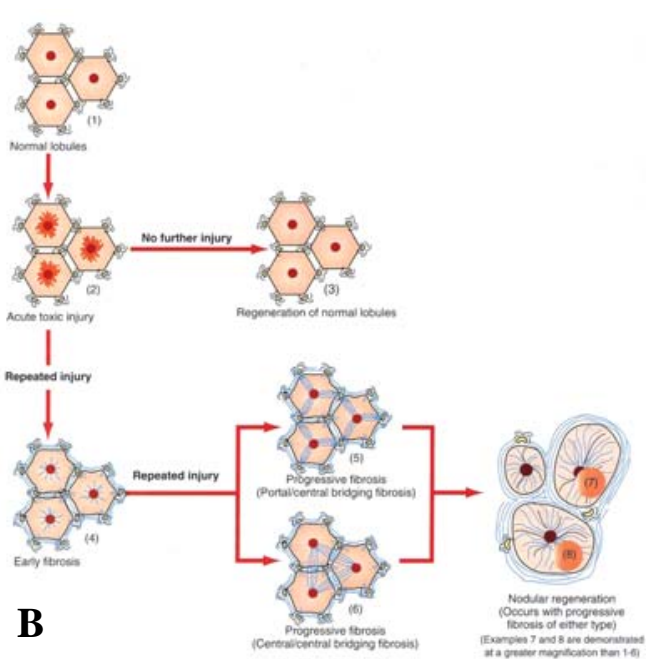

B

Figura 4 - Aspectos histopatológicos da cirrose hepática. A) Fígado cirrótico canino. Observe a grande quantidade de nódulos regenerativos na superfície hepática, indicando intensa atividade de morte celular e regeneração. B) Esquema demonstrando o padrão morfológico da deposição de colágeno perivascular após injúria celular, formando pontes de colágeno porta-porta, centro-porta e centro-centro. O resultado final é o isolamento de grandes nódulos regenerativos, circundados por extensas faixas de tecido conjuntivo

As mudanças na arquitetura hepática são acompanhadas por anormalidades na vascularização, resultando em desvios (shunts) vasculares e redução na disponibilidade de nutrientes para as células hepáticas (SCHUPPAN; AFDHAL, 2008). As células endoteliais formadoras dos sinusóides hepáticos apresentam fenestrações (Figura 5A) que permitem a passagem direta de nutrientes e oxigênio para os hepatócitos (JUNQUEIRA; CARNEIRO, 2004). Durante o desenvolvimento da doença crônica, ocorre deposição de colágeno no espaço de Disse (perissinusoidal - Figura 5C), o que promove a capilarização dos vasos sinusoidais (Figura 5B), aumentando a resistência ao fluxo sanguíneo e reduzindo a disponibilidade de oxigenação celular, induzindo a hipóxia local e subseqüente angiogênese (DI BONZO et al., 2009). Todo este processo de remodelação da arquitetura vascular, com capilarização dos sinusóides e desvios (shunts) intra-hepáticos, pode levar a hipertensão portal e falência hepática. A hipertensão portal é considerada a complicação clínica mais importante 
da cirrose, sendo diretamente responsável pela formação de varizes esofágicas e gástricas, além de desvios do sangue portal na circulação sistêmica. Estas alterações podem ocasionar, respectivamente, sangramentos varicosos (associados com alta taxa de mortalidade) e aumento na circulação sistêmica de drogas, toxinas e bactérias, contribuindo para a encefalopatia hepática e sepsis (FERNÁNDEZ et al., 2009).

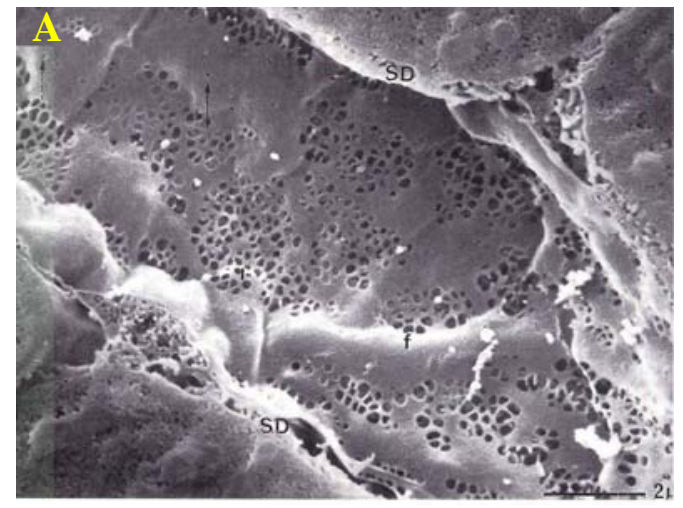

Fígado Normal

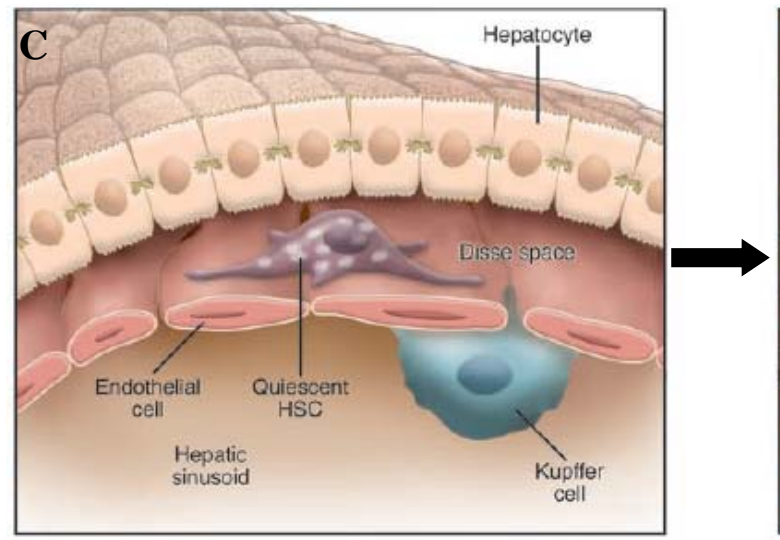

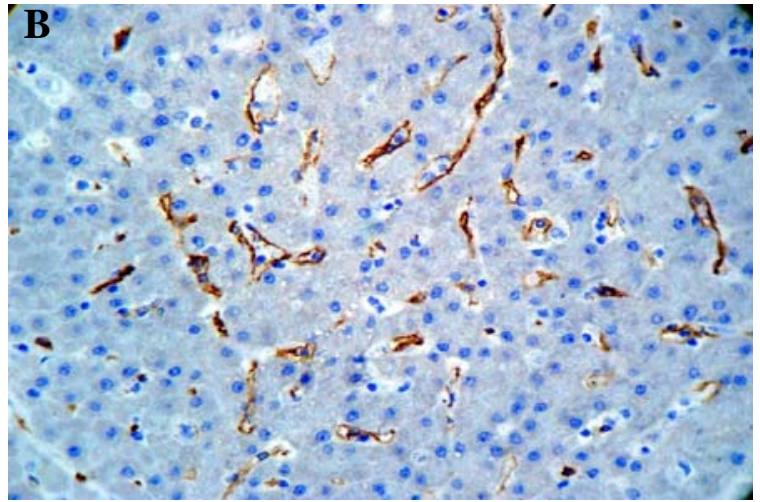

Injúria Hepática Crônica

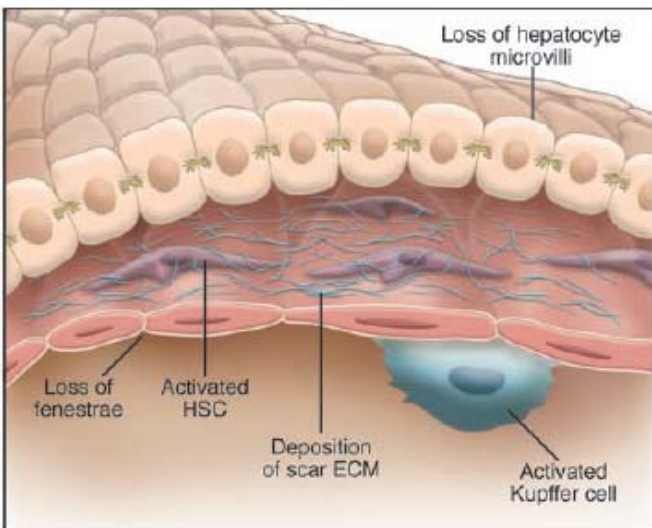

Fonte: (JUNQUEIRA; CARNEIRO, 2004; LIDA et al., 2005; IREDALE, 2007)

Figura 5 - Capilarização dos sinusóides na cirrose hepática. A) Microscopia eletrônica de varredura mostrando as fenestrações das células endoteliais sinusoidais; B) Imunohistoquímica para CD34, marcador específico de células endoteliais de capilares sanguíneos, comprovando a capilarização dos vasos sinusoidais na cirrose hepática. C) Esquema demonstrando a deposição de colágeno no espaço perissinusoidal após injúria hepática, pela ativação das células estreladas e células de Kupffer. Observe a perda das fenestrações das células endoteliais sinusoidais e dos microvilos dos hepatócitos 


\subsection{MECANISMOS DE FIBROGÊNESE HEPÁTICA}

A fibrose é o grande marcador tecidual da cirrose hepática e, antigamente, era considerada como um processo passivo resultante do colapso do estroma pré-existente, formando os septos fibrosos. Após duas décadas de estudos experimentais e clínicos, atualmente sabe-se que a deposição e remoção de matriz extracelular são controladas por um mecanismo ativo de cicatrização e reparação tecidual, que envolve diversos tipos celulares, citocinas e fatores de crescimentos (GRESSNER; WEISKIRCHEN, 2006). Muitos destes avanços foram relatados pelo pesquisador Scott L. Friedman, que iniciou seus trabalhos com as células de Ito ou lipócitos, atualmente conhecidas como células estreladas e diretamente envolvidas no controle da fibrogênese hepática (FRIEDMAN; ROLL, 1987; FRIEDMAN et al., 1992; FRIEDMAN, 2008a,b). Como muitos mecanismos celulares e moleculares foram descobertos e relacionados com a progressão e/ou resolução da fibrose hepática, será apresentada nos próximos itens uma visão condensada destes mecanismos.

\subsubsection{Matriz extracelular no fígado normal e cirrótico}

No fígado normal, a matriz extracelular (MEC) ocupa menos de 3\% da área total e é composta por diferentes tipos de colágeno, fibronectina e proteoglicanas, que variam em sua localização dentro da MEC. Os colágenos fibrilares I, III e IV estão distribuídos, principalmente, na cápsula hepática e ao redor dos tratos portais e ductos biliares. Os espaços perissinusoidais não possuem membrana basal típica, no entanto, apresentam uma estrutura semelhante composta pelos colágenos fibrilares tipo I, III e V, colágeno microfibrilar IV e colágeno da membrana basal IV e XVIII, além de lamina, fibronectina e proteoglicanos (SCHUPPAN et al., 2001; OKASAKI et al., 2003). No fígado cirrótico, os componentes da MEC aumentam sua concentração tecidual, principalmente, pela deposição de colágenos tipo I e III nos espaços perissinusoidais, levando a capilarização dos sinusóides. Os septos fibrosos também são marcados pelo aumento dos colágenos tipo I, III e IV. Outros componentes, como laminina, fibronectina e outras glicoproteínas também se encontram aumentadas no fígado cirrótico (BEDOSSA; PARADIS, 2003; OKASAKI et al., 2003). A distribuição dos componentes da MEC no fígado normal e cirrótico está representada na figura 6 . 


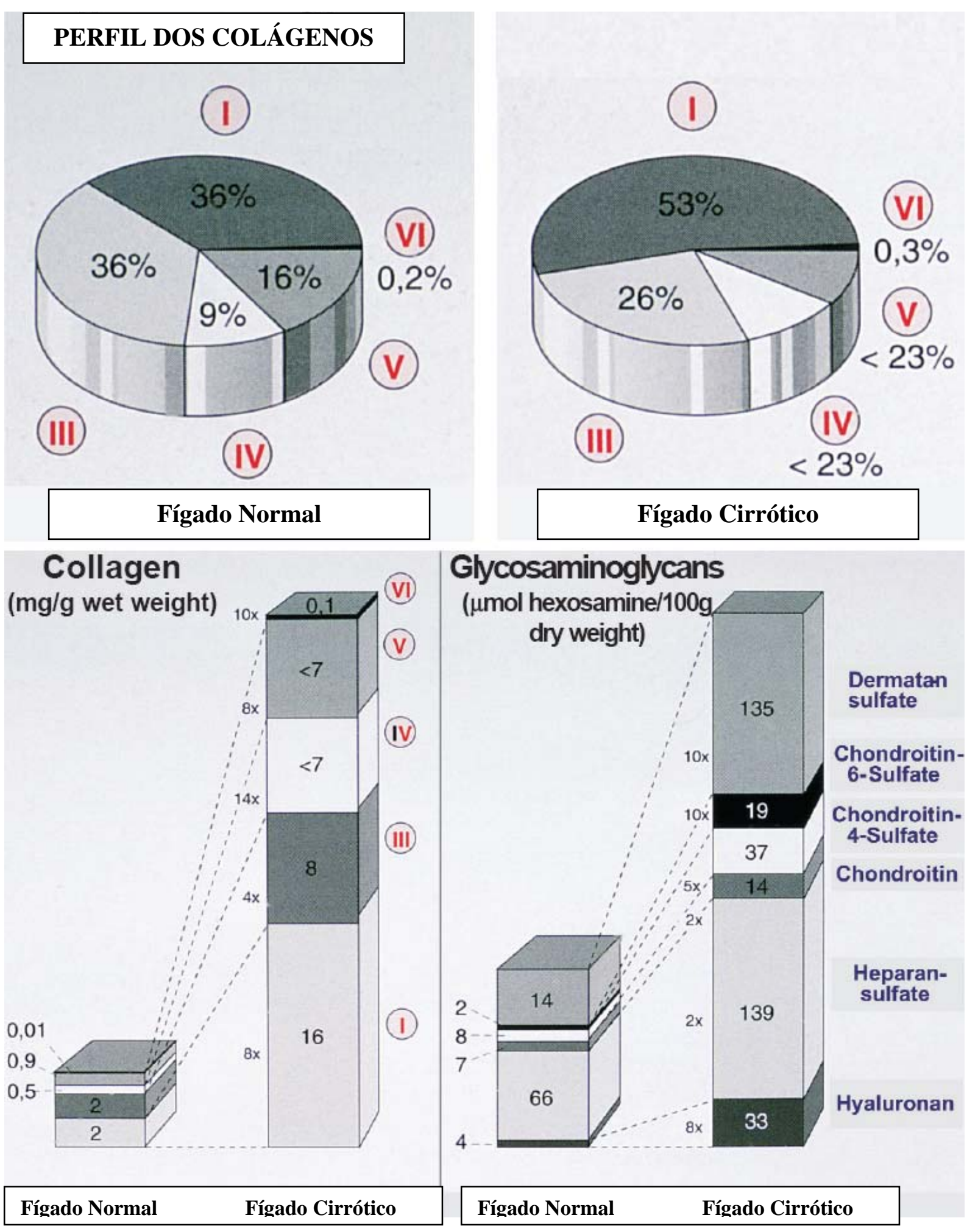

Fonte: (modificado de GRESSNER; WEISKIRCHEN, 2006)

Figura 6 - Demonstração gráfica da composição dos componentes da matriz extracelular no fígado normal e seu aumento no fígado cirrótico, apresentando a \% e a relação por peso, além de quantas vezes ocorre o aumento de cada componente 


\subsubsection{Células envolvidas na fibrogênese hepática}

Os miofibroblastos hepáticos são as principais células envolvidas no mecanismo de fibrogênese e constituem uma população celular heterogênea, a qual apresenta expressão de $\alpha$-actina de músculo liso ( $\alpha$-SMA) e grande capacidade proliferativa, pró-fibrogênica, próinflamatória e pró-angiogênica (NOVO et al., 2009). Normalmente, estas células são derivadas de outras através de mecanismos de ativação e transdiferenciação, como ocorre com as células estreladas hepáticas e os fibroblastos portais (GUYOT et al., 2006; FRIEDMAN, 2008b). No entanto, evidências sugerem que os miofibroblastos também podem ser originados a partir de células tronco mesenquimais ou fibrócitos circulantes derivados da medula-óssea (FORBES et al., 2004; KISSELEVA et al., 2006) ou pela transição epitelial-mesenquimal (EMT) dos hepatócitos e colangiócitos (ZEISBERG et al., 2007) (Figura 7).

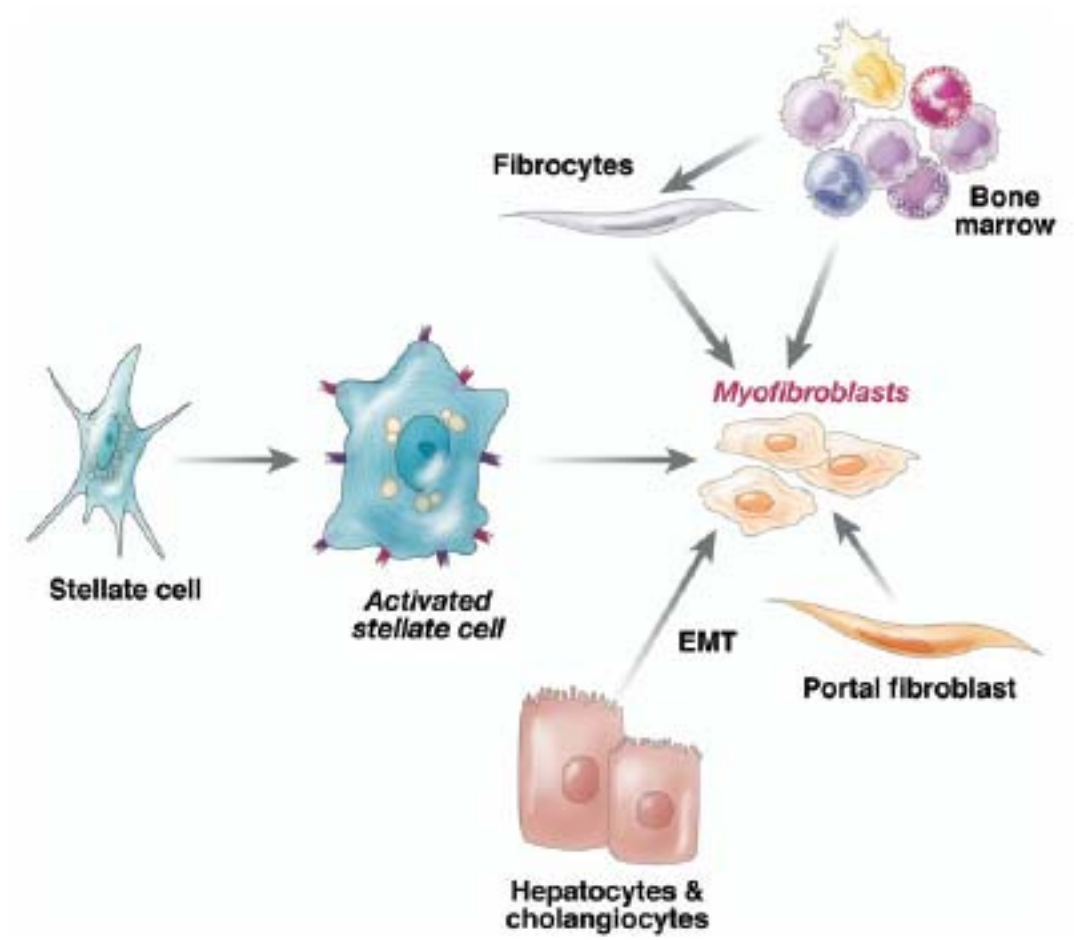

Fonte: (FRIEDMAN, 2008a)

Figura 7 - Representação dos principais tipos celulares com reconhecida capacidade de originar miofibroblastos hepáticos, responsáveis pela produção e deposição de matriz extracelular na fibrose hepática. A principal célula envolvida é representada pelas células estreladas, seguida pelos fibroblastos portais. A participação de células da medula-óssea é relativamente pequena, assim como a transição epitelial-mesenquimal (EMT) de hepatócitos e colangiócitos 


\subsubsection{Células estreladas hepáticas (HSCs)}

Historicamente, as células estreladas foram relatadas pela primeira vez por Karl Wilhelm von Kupffer, no ano de 1876, identificando-as pelos vacúolos lipídicos contendo vitamina A. Estas células receberam muitas denominações durante sua história, como lipócitos, células armazenadoras de gordura (fat-storing cells), células intersticiais, células perissinusoidais e células de Ito. Esta falta de definição causou algumas confusões, no entanto, a nomenclatura dessas células foi oficialmente padronizada no ano de 1996, sendo a partir de então chamadas células estreladas hepática (FRIEDMAN, 2008b).

Estudos pioneiros realizados por De Leeuw et al. (1984) e Friedman et al. (1992) demonstraram a grande versatilidade das células estreladas isoladas de animais e humanos. A partir de então, houve um crescimento exponencial no número de trabalhos publicados sobre o assunto (FRIEDMAN, 2008b). No fígado normal, as HSC correspondem a 1,4\% do volume total do fígado ou $\approx 15 \%$ do número total de células hepáticas, e estão presentes na proporção de 1:20 em relação aos hepatócitos. As HSC estão localizadas no espaço perissinusoidal (espaço de Disse), entre os hepatócitos e as células endoteliais sinusoidais (Figura 8A). Em seu estado quiescente, as HSCs apresentam diversos vacúolos lipídicos localizados ao redor do núcleo (Figura 8B), com função primordial de armazenamento de vitamina A (MOREIRA, 2007; FRIEDMAN, 2008b). Estes vacúolos são perdidos quando as HSCs são ativadas e se diferenciam em miofibroblastos hepáticos (LI; FRIEDMAN, 2003).

Após injúria hepática, células inflamatórias são mobilizadas e direcionadas para a área afetada, formando um infiltrado composto por linfócitos, neutrófilos, plaquetas e monócitos, incluindo as células de Kupffer. Na fase inicial da lesão, as células de Kupffer são importantes para a sinalização da perda dos vacúolos lipídicos e conseqüente ativação das HSCs, e juntamente com a plaquetas, estimulam sua proliferação através da secreção dos fatores de crescimento TGF- $\alpha$, EGF e PDGF (UENO; SATA; TANIKAWA, 2003). A ativação das células estreladas é marcada pela expressão de $\alpha$-SMA, aumento na migração, contratilidade e proliferação celular, produção de citocinas capazes de recrutar células inflamatórias e outras HSCs, e principalmente, capacidade pró-fibrogênica (MOREIRA, 2007). O comportamento das HSCs pode ser dividido em três estágios didáticos: iniciação, onde ocorrem as mudanças iniciais na expressão gênica e fenótipo celular; perpetuação, correspondente a manutenção do fenótipo ativado e estabelecimento da fibrose; e resolução, onde ocorre indução da apoptose ou reversão do fenótipo de miofibroblastos (FRIEDMAN, 2008a,b,c) (Figura 9). 

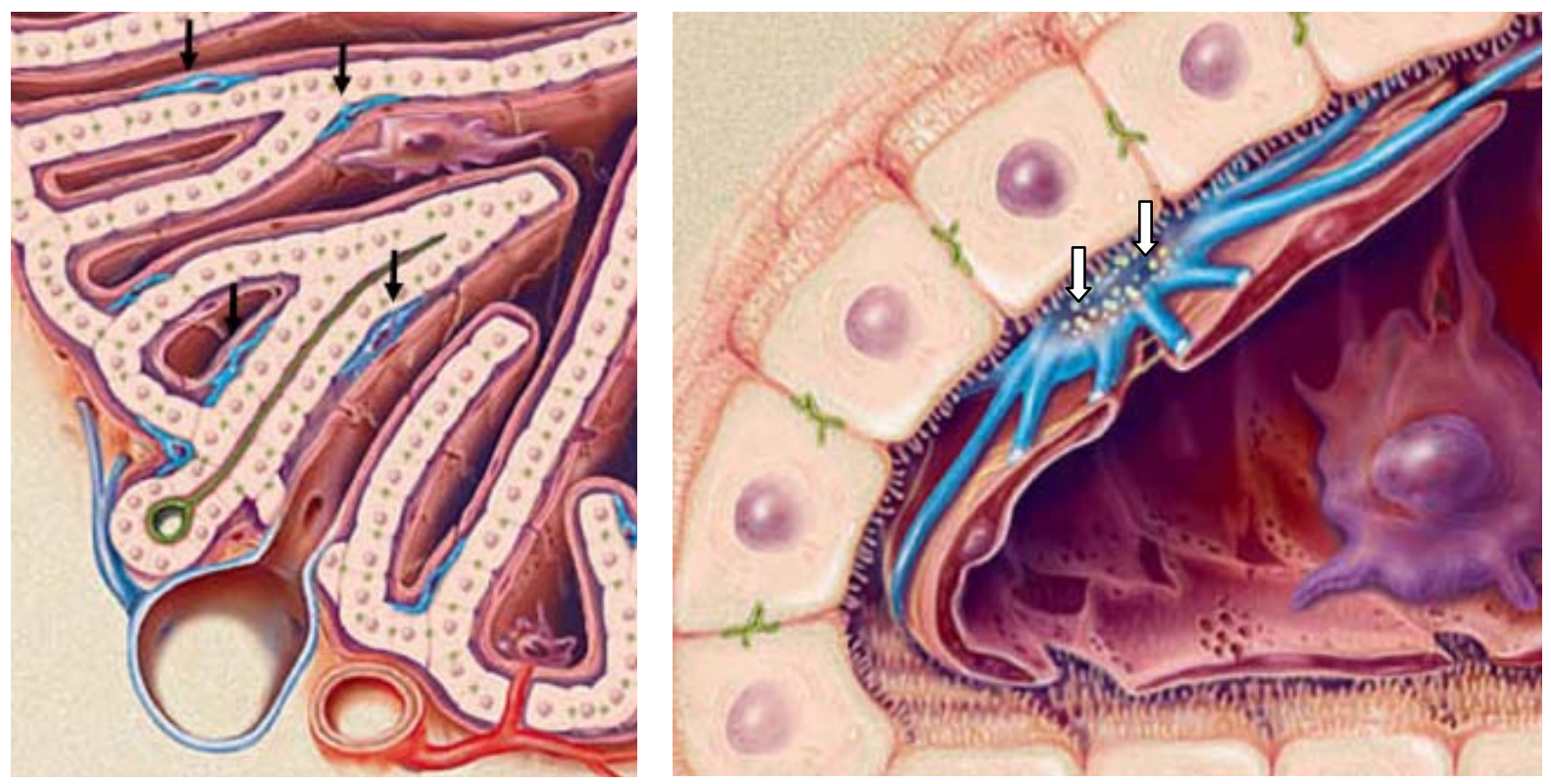

Fonte: (modificado de FRIEDMAN, 2008b)

Figura 8 - Desenho esquemático da morfologia das células estreladas quiescentes no fígado normal. (A) As HSCs estão localizadas no espaço perissinusoidal (setas pretas) e (B) possuem vacúolos lipídicos perinucleares com vitamina A (setas brancas)

\subsection{Iniciação}

A fase de iniciação (ativação) das células estreladas hepáticas ocorre após a liberação de mediadores químicos por células lesadas, que podem ser hepatócitos, células endoteliais, células de Kupffer, colangiócitos, plaquetas, assim como células tumorais de neoplasias primárias ou metastáticas (LI; FRIEDMAN, 2003). Esta fase também é conhecida como estágio pré-inflamatório. Dentre os principais fatores de iniciação, os hepatócitos ou colangiócitos são responsáveis pela liberação de espécies reativas de oxigênio e fragmentos apoptóticos, além do clássico estímulo via necrose associada à peroxidação lipídica (FRIEDMAN, 2008b). Acredita-se que a liberação de TGFb-1 pelos hepatócitos necróticos seja um dos primeiros sinais para ativação das HSCs quiescentes (LIU; HU; YIN, 2006). Por sua vez, as células de Kupffer também contribuem na iniciação por ação do TGF $\beta-1$ e espécies reativas de oxigênio. Células endoteliais participam na conversão da forma latente do TGF $\beta$-1 em sua forma ativa e pró-fibrogênica, enquanto as plaquetas produzem PDGF, TGFß-1 e EGF (FRIEDMAN, 2008c). Nesta fase também ocorre rápida indução do receptor $\beta$ do PDGF (rßPDGF) e da expressão gênica de colágeno tipo I (FRIEDMAN, 2008a). 


\subsection{Perpetuação}

Após iniciação, as HSCs sofrem diversas alterações fenotípicas e metabólicas que levam à secreção e acúmulo da MEC. Nesta fase, são observados diferentes comportamentos celulares: proliferação, quimiotaxia, fibrogênese, contratilidade e degradação da MEC.

Proliferação: O fator de crescimento derivado de plaquetas (PDGF), é considerado o mais potente ativador da proliferação celular das HSCs, e seus efeitos são otimizados devido aumento na expressão de seus receptores (rßPDGF) na fase de iniciação. Outros compostos estão diretamente relacionados com a proliferação celular, como os fatores de crescimento do endotélio vascular (VEGF), fibroblastos (bFGF), epidermal (EGF), transformador alfa (TGF$\alpha$ ), trombina e seus respectivos receptores (LI; FRIEDMAN, 2003).

Quimiotaxia: O aumento local de HSCs não ocorre apenas por proliferação, mas também por migração devido sinais quimioatrativos de células inflamatórias e das próprias HSCs. Dentre os principais quimioatrativos, pode-se citar: PDGF, MCP-1 (proteína quimiotática de monócitos) e CXCR3 (receptor 3 de quimiocina) (FRIEDMAN, 2008c).

Fibrogênese: Nesta fase as HSCs ativadas iniciam a síntese e deposição de colágeno no tecido hepático. Diversos fatores fibrogênicos foram identificados, como interleucina $1 \beta$ (IL-1 $\beta$ ), fator de necrose tumoral (TNF), peróxidos lipídicos e acetaldeído. No entanto, o fator fibrogênico considerado mais potente na produção de colágeno tipo I e outros componentes da MEC é o TGF $\beta$-1 (LI; FRIEDMAN, 2003; FRIEDMAN, 2008b). A superfamília do TGF $\beta$ consiste de mais de 40 ligantes, incluindo três isoformas do TGF $\beta(-1,-2$ e -3$)$, proteínas morfogenéticas óssea (BMPs), entre outros. Os efeitos do TGF $\beta-1$ são classicamente mediados pela sinalização nuclear via proteínas da família Smad, principalmente pela indução da fosforilação em Smad2/3 (PARSONS; TAKASHIMA; RIPPE, 2007). Por outro lado, a BMP-7 é considerada o mais importante fator de oposição aos efeitos biológicos do TGF $\beta$-1 (ZEISBERG et al., 2003).

Outro potente fator fibrogênico hepático é o fator de crescimento do tecido conjuntivo $(\mathrm{CTGF}=\mathrm{CCN} 2)$, produzido por hepatócitos, colangiócitos e células estreladas em tecidos fibróticos (GRESSNER; GRESSNER, 2008). O grande aumento em sua expressão ocorre ao 
nível transcricional, sendo estimulado por fatores de crescimento específicos, como pelo TGF $\beta$-1 ou endotelina-1, mas também por diversas influências do microambiente, como estresse biomecânico e hipóxia (RACHFAL; BRIGSTOCK, 2003; LEASK; ABRAHAM, 2006). Ainda, o aumento da expressão de CTGF em células estreladas está relacionado com altas taxas de glicose e hiperinsulinemia, e pode ser um mecanismo envolvido na progressão da fibrose na esteato-hepatite não-alcoólica (PARADIS et al., 2001).

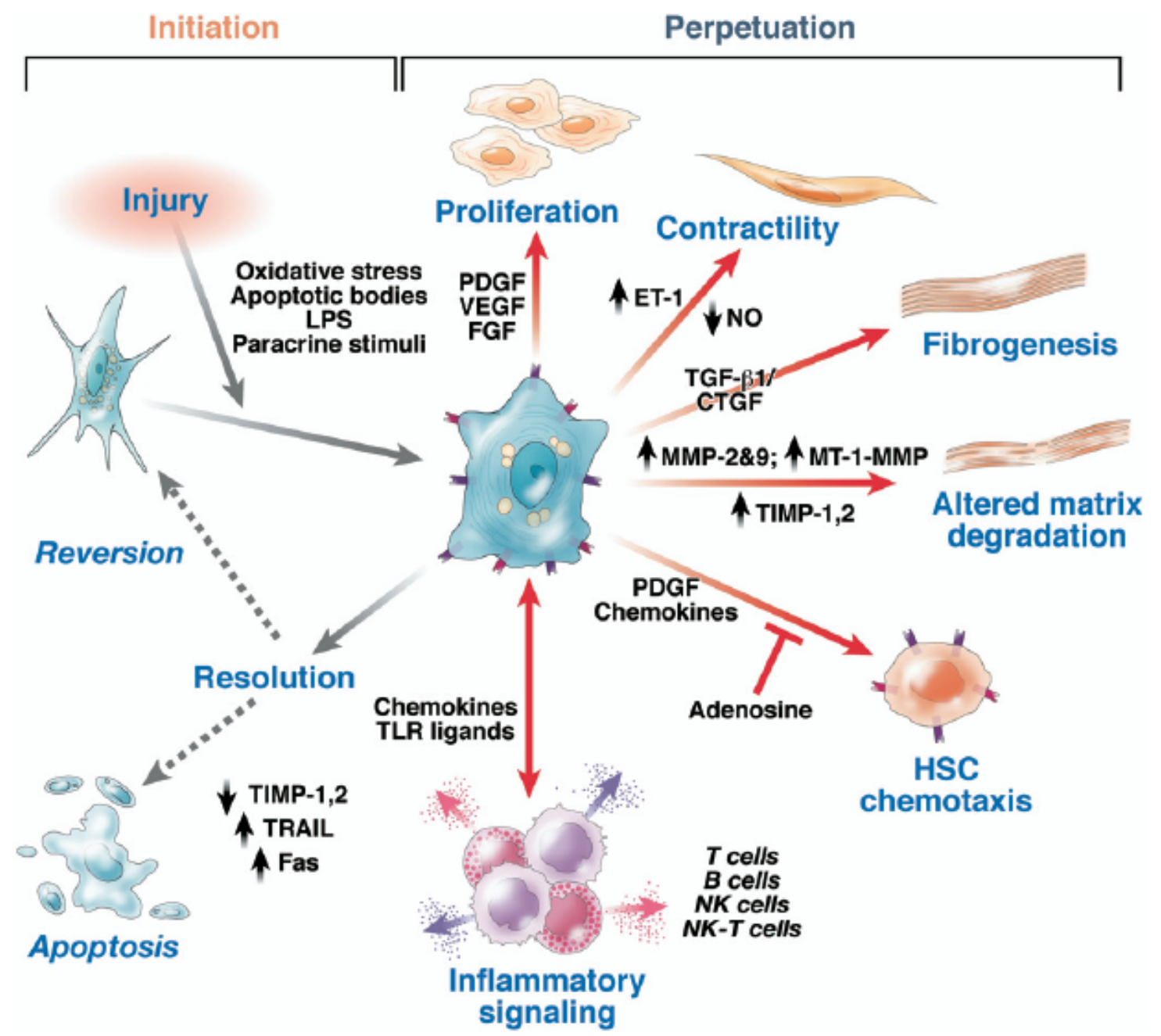

Fonte: (FRIEDMAN, 2008b)

Figura 9 - Representação esquemática das fases de iniciação, perpetuação e resolução das células estreladas hepáticas. A ativação das HSCs ocorre após injúria celular por diferentes causas: estresse oxidativo, corpos apoptóticos, lipopolisacarídeos (LPS) ou estímulos parácrinos de células adjacentes, tais como hepatócitos, células de Kupffer e células endoteliais. A fase de perpetuação ocorre com a participação de diversas citocinas e fatores de crescimento 
Contractilidade: A contração das HSCs é um dos principais determinantes do aumento na resistência portal existente na fibrose/cirrose hepáticas, prejudicando o fluxo de sangue portal pela constrição dos sinusóides e contração do fígado cirrótico. A endotelina-1 (ET-1) e óxido nítrico (NO) são os principais reguladores da contractilidade das HSCs, no entanto, outros mediadores estão envolvidos no processo, como por exemplo, angiotensina II, eicosanóides, somatostina e outros (FRIEDMAN, 2008b). O principal marcador celular é a proteína de citoesqueleto alfa-actina de músculo liso ( $\alpha$-SMA) (NOVO et al., 2009).

Degradação da matriz extracelular: A fibrose é resultante do desequilíbrio entre produção e degradação da MEC pelos miofibroblastos. A degradação de componentes da matriz também ocorre durante a invasão tumoral, sendo considerada patológica. No entanto, este mesmo mecanismo possui uma grande importância terapêutica em pacientes portadores de hepatites crônicas, reduzindo o colágeno depositado no fígado (FRIEDMAN, 2008c). O elemento crítico nesse processo são as enzimas chamadas metaloproteinases da matriz (MMPs), que degradam moléculas específicas de colágeno e outros componentes da MEC. Por sua vez, estas enzimas são reguladas pelos inibidores teciduais das metaloproteinases (TIMPs) (Figura 10) (HAN, 2006). Estes mecanismos serão detalhados a seguir.

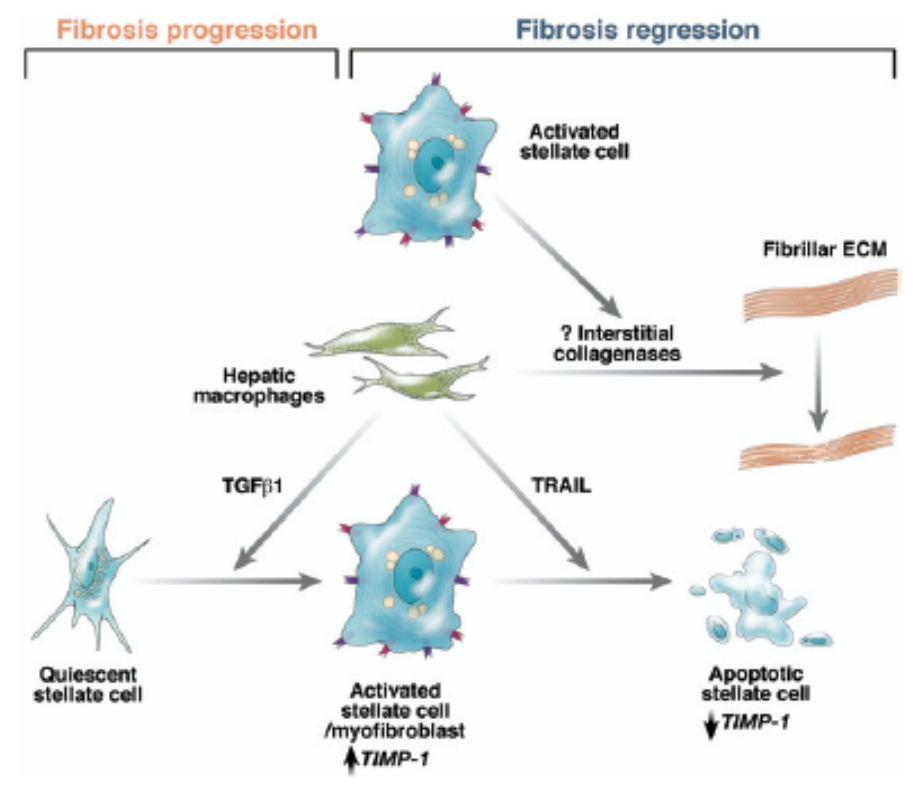

Fonte: (FRIEDMAN, 2008a)

Figura 10 - Ilustração demonstrando a produção de colagenases (MMPs) pelas células estreladas ativadas e células de Kupffer, degradando a MEC. Ao mesmo tempo, as HSCs também são responsáveis pela produção do inibidor da metaloproteinase, TIMP-1, que também é considerada um fator pró-apoptótico 


\subsection{Resolução}

A fase de resolução das células estreladas hepáticas ativadas do tecido hepático tem sido pesquisada como um possível alvo terapêutico na redução da fibrose hepática. Atualmente, acredita-se que este processo seja realizado por dois mecanismos principais: reversão do fenótipo ativado em miofibroblastos para o estado quiescente ou indução à apoptose (LI; FRIEDMAN, 2003). No entanto, a reversão do fenótipo das HSCs pode ser comprovado apenas em estudo in vitro (GACA et al., 2003). Durante a resolução da fibrose em modelos experimentais, ocorre um aumento do índice apoptótico nas HSCs, com aumento na expressão do inibidor tecidual de metaloproteinases, TIMP-1 (IREDALE et al., 1998; IREDALE, 2001). Ainda, evidências sugerem que as citocinas pró-fibrogênicas TGFß-1 e TNF- $\alpha$ inibem a apoptose nas HSCs, podendo ser caracterizados como mediadores de sobrevivência e/ou resistência ao estímulo apoptótico, contribuindo ainda mais para a fibrose hepática (SAILE et al., 1999). No entanto, apenas a apoptose das HSCs não é suficiente para a resolução da fibrose, sendo necessário acionar os mecanismos de degradação da matriz extracelular (RODERFELD; HEMMANN; ROEB, 2007).

\subsubsection{Degradação da matriz extracelular e resolução da fibrose}

Diversas evidências demonstram que a fibrose hepática pode ser revertida em modelos experimentais e em algumas doenças humanas. Apesar de não ser um conceito exatamente novo, estas evidências geraram um novo paradigma de que a matriz extracelular não é uma estrutura estática e imutável, alavancando uma série de estudos sobre os principais mecanismos envolvidos na manutenção e remoção da MEC no tecido hepático (ISMAIL; PINZANI, 2009). No fígado normal, a homeostasia da matriz extracelular é mantida por um preciso e permanente sistema de renovação de seus componentes (HEMMANN et al., 2007). Basicamente, os elementos chaves na regulação deste processo são as metaloproteinases (MMPs) e seus inibidores teciduais (TIMPs) (FRIEDMAN, 2008a). Nas doenças hepáticas crônicas, as células estreladas ativadas em miofibroblastos são as principais produtoras dos componentes da MEC (Figura 10), assim como das enzimas e proteínas reguladoras (TAKAHARA et al., 2003). 


\subsubsection{Estrutura e função das MMPs e TIMPs}

A MMPs fazem parte de uma grande família de endopeptidases dependentes de cálcio e zinco. Assim como outras proteases, as MMPs são produzidas em sua forma inativa (zimogênio), onde o sítio catalítico da enzima é ocupado por um pró-peptídeo, tornando-o inacessível para o substrato. Durante a ativação, este pró-peptídeo é clivado, tornando o sítio catalítico novamente disponível para o substrato (Figura 11) (CONSOLO et al., 2009). Até hoje, foram detectadas 29 tipos diferentes de MMPs, sendo classificadas em solúveis ou tipo membrana (MT-MMPs) de acordo com sua estrutura molecular. Basicamente, todas as MMPs solúveis são secretadas na forma inativa de pró-MMPs, enquanto as MT-MMPs são expressas na membrana celular como enzimas ativas. As MMPs solúveis podem ser divididas em colagenases, estromelisinas, gelatinases, matrilisinas e outras de acordo com o substrato alvo da matriz extracelular (Quadro 1) (NABESHIMA et al., 2003).

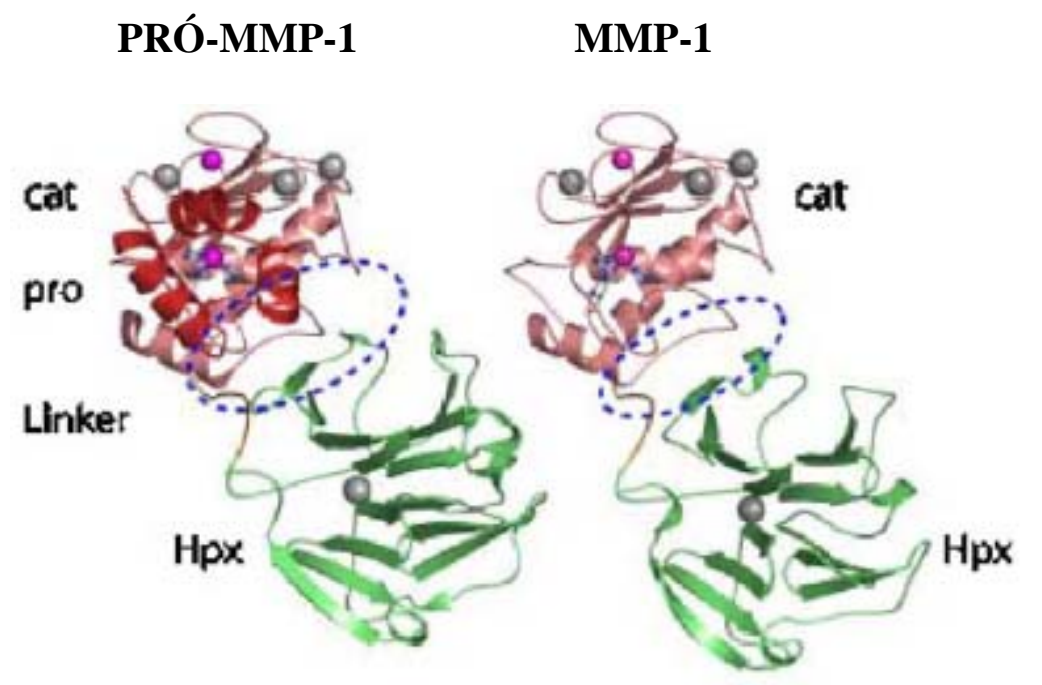

Fonte: (NAGASE; VISSE; MURPHY, 2006)

Figura 11 - Representação esquemática da estrutura da molécula da metaloproteinase de matriz 1 (MMP-1) em sua forma latente (pró-MMP1) ou ativa (MMP-1). Após ativação, a molécula de MMP-1 apresenta uma configuração 'aberta' em comparação à forma latente 
As TIMPs (inibidores teciduais das metaloproteinases) são proteínas secretadas para o controle da integridade da matriz extracelular através de sua atividade inibidora sobre as MMPs. Atualmente, são descritas quatro membros da família das TIMPs (TIMP-1, -2, -3 e 4), com características estruturais semelhantes. A molécula é composta por dois domínios, um domínio grande N-terminal e um pequeno C-terminal. Sabe-se que o sítio inibitório das MMPs está situado no domínio N-terminal. A principal função das TIMPs é regular a degradação da membrana basal e da matriz extracelular pelas MMPs durante o desenvolvimento e remodelamento tecidual. As TIMPs-1 e -3 são mais efetivas na inibição da MMP-13 do que a TIMP-2, que por sua vez é mais efetiva na inibição da MMP-9. Não existe diferença no potencial de inibição entre as TIMP-1 e -3 em relação às MMPs-1, -2, -3 e -9 (NABESHIMA et al., 2003). De maneira geral, a TIMP-1 apresenta maior importância na regulação do processo fibrótico (IREDALE et al., 1997), além de apresentar ação antiapoptótica nas células estreladas hepáticas (MURPHY et al., 2002).

\begin{tabular}{|c|c|c|}
\hline Proteínas & MMP & Substrato \\
\hline Colagenase 1 & MMP-1 & $\begin{array}{c}\text { Colágenos I, II, III, VII, X, gelatinas, agrecan e } \\
\text { entactina }\end{array}$ \\
\hline Colagenase 2 & MMP-8 & Colágenos I, II, III, agrecan, proteína ligadora \\
\hline Colagenase 3 & MMP-13 & Colágeno I, II e III \\
\hline Gelatinase A & MMP-2 & $\begin{array}{l}\text { Gelatinas, colágeno I, IV, V, XIV, elastina, } \\
\text { agrecan e vitronectina }\end{array}$ \\
\hline Gelatinase B & MMP-9 & $\begin{array}{c}\text { Colágeno IV, gelatinas, agrecan, fibronectina, } \\
\text { elastina, laminina e pró-MMP-1 }\end{array}$ \\
\hline Estromelisina 1 & MMP-3 & $\begin{array}{l}\text { Colágeno III, IV, IX, gelatinas, agrecan, } \\
\text { fibronectina, laminina, pró-MMP-1 }\end{array}$ \\
\hline Estromelisina 2 & MMP-10 & $\begin{array}{c}\text { Colágeno IV, agrecan, fibronectina, elastina e } \\
\text { laminina }\end{array}$ \\
\hline Estromelisina 3 & MMP-11 & $\begin{array}{l}\text { Colágeno I, IV, V, VII, X, gelatinas, agrecan, } \\
\text { fibronectina, elastina, laminina e vitronectina }\end{array}$ \\
\hline Matrilisina 1 & MMP-7 & Gelatinas, fibronectina e pró-MMP-1 \\
\hline MT1-MMP & MMP-14 & Colágeno I, II, III, fibronectina e gelatinas \\
\hline МТ2-MMP & MMP-15 & Pró-MMP-2 \\
\hline МT3-MMP & MMP-16 & Pró-MMP-2 \\
\hline
\end{tabular}

Fonte: (modificado de CONSOLO et al., 2009)

Quadro 1 - Resumo das principais metaloproteinases da matriz e seus principais substratos alvos-específicos da MEC 
2.4.3.2 Mecanismos de fibrólise nas doenças hepáticas crônicas

No fígado, foram detectadas as MMPs-1, -2, -3, -7, -8, 9, -10, -13, -14, -15 e -16 (TAKAHARA et al., 2003). As MMPs -2, -13 e -3 são secretadas, principalmente, pelas HSCs ativadas e a MMP-9 pelas células de Kupffer (ARTHUR, 2000). Diversos estudos demonstraram variação na expressão destas enzimas ao longo da deposição e degradação dos componentes da MEC (THERET et al., 1997, 1999; HEMMANN et al., 2007). Na fase inicial da injúria, as HSCs iniciam a expressão das MMPs-13 e 3, além do ativador de plasminogênio tipo uroquinase (uPA) e outros componentes do sistema de plasmina. Com a cronicidade da lesão hepática, as células expressam diferentes tipos de MMPs e TIMPS. (FRIEDMAN, 2008c; CONSOLO et al., 2009). Em roedores, apenas um tipo de colagenase intersticial foi identificada, a MMP-13, sendo, portanto, equivalente a MMP-1 encontrada em humanos (RODERFELD, HERMMANN; ROEB, 2007). A figura 12 demonstra a dinâmica da ativação das MMPs e TIMPs envolvidas na fibrogênese e fibrólise hepáticas.

$\mathrm{Na}$ fase inicial da injúria hepática, ocorre degradação da matriz extracelular normal presente no fígado para facilitar a proliferação de novas células hepáticas e a deposição da nova matriz recém-sintetizada.. Esta degradação inicial da MEC ocorre pelo pico das MMPs3 e -13, as quais também são responsáveis pela ativação das MMPs-2, -14 e -9 (Figura 12). A MMP-9 está mais associada à redução da atividade inflamatória nas doenças hepáticas crônicas do que propriamente à redução da fibrose. No entanto, possui participação na ativação da forma latente do TGF $\beta-1$, o qual estimula a produção de colágeno na fase inicial de ativação das células estreladas (HEMMANN et al., 2007).

Os níveis das TIMPs-1 e -2 aumentam gradativamente no decorrer desta primeira fase, principalmente TIMP-1, a maior responsável pela inibição da MMP-13. O aumento na expressão da TIMP-1 acarreta no acúmulo de tecido cicatricial no tecido hepático, que caracteriza a fase de fibrogênese. A produção das TIMPs também é de responsabilidade das células estreladas (ARTHUR, 2000). No entanto, na fase inicial também ocorre liberação pelas células de Kupffer e hepatócitos (HEMMANN et al., 2007). Na fase de degradação da MEC ou fibrólise ao final do processo, o nível da TIMP-1 declina, permitindo a degradação do colágeno pelas MMPs. Além disso, a TIMP-1 inibe a morte celular programada (apoptose) das células estreladas, sendo considerada então, a principal molécula envolvida na fibrose tecidual. O aumento na atividade de degradação do colágeno é o maior mecanismo na 
resolução da fibrose hepática. Nesse processo, a expressão das TIMPs diminui rapidamente, enquanto as colagenases continuam sendo expressas (IIMURO; BRENNER, 2008).

De maneira geral, observa-se que as MMP-2/MMP-14 e MMP-9 apresentam importante função fibrogênica nas fases iniciais de injúria hepática. $\mathrm{Na}$ fase tardia ou de fibrólise, as MMP-2 e -14 podem exercer suas atividades proteolíticas em gelatinas e colágenos intersticiais após redução dos níveis de TIMP-1 (HEMMANN et al., 2007). Foi demonstrando que a citocina TNF- $\alpha$ estimula a expressão das MMPs e TIMPs pelas células estreladas hepáticas, comprovando que os componentes inflamatórios são cruciais para a degradação das MEC. Por outro lado, demonstrou-se que o TGF $\beta$-1 induz apenas a expressão de TIMPs, corroborando sua ação pró-fibrogênica (CONSOLO et al., 2009). Adicionalmente TIMP-1 também é regulada drasticamente por outras citocinas inflamatórias, tais como IL-1b, IL-6, IL-11 (RODERFELD, HERMMANN; ROEB, 2007).

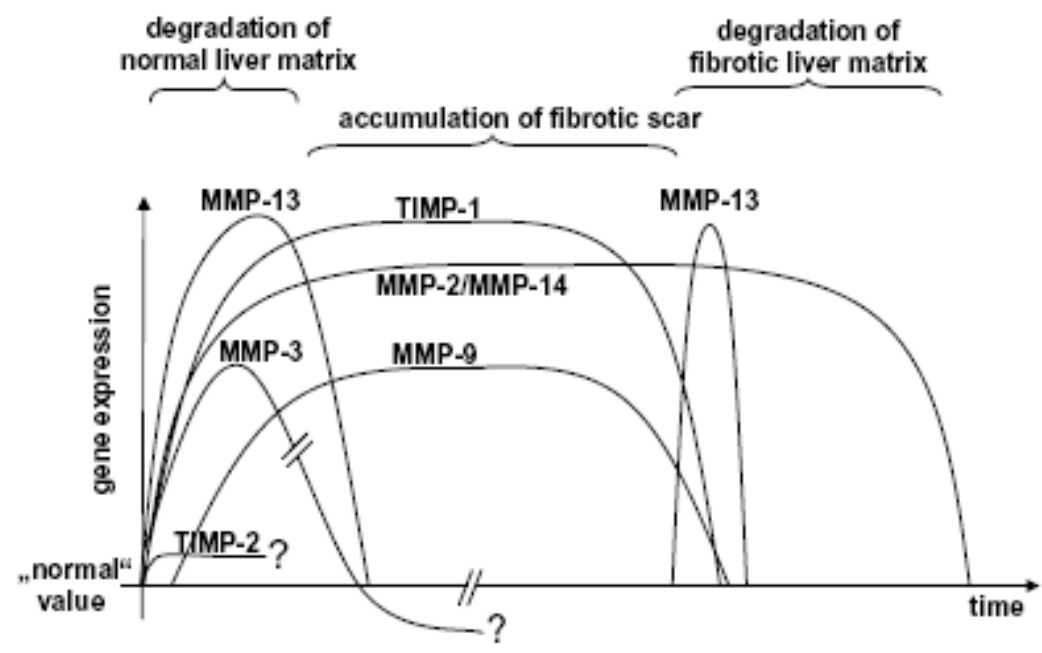

Fonte: (HEMMANN et al., 2007)

Figura 12 - Expressão gênica temporal das metaloproteinases (MMPs) e seus inibidores teciduais (TIMPs) na fibrogênese e fibrólise hepáticas. Na degradação da matriz extracelular normal, ocorre um pico na expressão das MMP-13 e MMP-3, degradando o colágeno intersticial e induzindo a ativação de outras MMPs. O acúmulo do tecido cicatricial é marcado pelo aumento na expressão do TIMP-1, o qual inibi grande parte da atividade proteolítica das MMPs. Neste mesmo período, ocorre aumento das MMP-2/MMP-14, as quais permanecem elevadas até o final da resolução da MEC. Nesta etapa de redução da fibrose hepática, ocorre redução na expressão gênica do TIMP-1, permitindo a degradação da MEC pelas MMPs. Também ocorre um pico da MMP-13, a mais importante enzima relacionada com a degradação do colágeno intersticial, principalmente os tipos I e III 


\subsubsection{Sistema ativador plasminogênio - plasmina}

Os ativadores de plasminogênio (PAs) são proteases serinas bem caracterizadas que catalisam a conversão do plasminogênio em plasmina, formando o sistema PA-plasmina, o qual é importante no processo de proteólise da matriz extracelular. Sabe-se que as células estreladas são as principais responsáveis pela síntese dos componentes chaves do sistemda ativador de plaminogênio em plasmina (RODRÍGUEZ-FRAGOSO et al., 1999). A participação da plasmina na renovação da MEC está relacionada com sua própria ação proteolítica, além de seu efeito ativador sobre as MMPs, citocinas pró-fibrogênicas e TGF $\beta-1$ (ZHANG et al., 1999). O ativador de plasminogênio tipo tecidual (tPA) ou tipo uroquinase (uPA) são os principais ativadores de plasminogênio em mamíferos, os quais ativam a próenzima de plaminogênio em plasmina (HIGAZI et al., 2008).

\subsection{COMUNICAÇÃO INTERCELULAR E CONEXINAS}

As células presentes em organismos multicelulares possuem uma grande capacidade de se comunicarem por diferentes mecanismos que possibilitam a manutenção da homeostasia celular. Assim, através da comunicação extracelular, intracelular e intercelular, as células regulam e mantêm um fino e complexo controle de suas funções fisiológicas e metabólicas (VINKEN et al., 2008). A comunicação intercelular é mediada pelas junções comunicantes do tipo gap e estão presentes em quase todas as células de vertebrados, com exceção das células sanguíneas vermelhas, fibras musculares esqueléticas maduras, alguns neurônios, plaquetas e espermatozóides (MESNIL et al., 2005).

A primeira descrição das junções gap foi realizada por Loewenstein et al. (1965). Loewenstein e Kanno (1967) demonstraram a incapacidade de troca de íons entre células tumorais hepáticas de rato. No mesmo ano, Revel e Karnovsky apresentaram a estrutura hexagonal das subunidades presentes nas junções intercelulares da membrana plasmática de hepatócitos, e receberam a denominação de canais comunicantes do tipo gap. Alguns anos depois, Goodenough (1974) isolou e apresentou as duas proteínas presentes nas junções comunicantes de hepatócitos de camundongo, com pesos moleculares de 26 e $32 \mathrm{kDa}$, sendo denominadas de conexinas $(\mathrm{Cx})$. 
As junções comunicantes do tipo gap são regiões especializadas da membrana plasmática que formam canais justapostos entre duas células adjacentes (Figura 13A-C), individualmente compostos por uma estrutura básica denominada hemicanais ou conexons. Por sua vez, os conexons são formados por seis subunidades protéicas chamadas de conexinas que se distribuem hexagonalmente formando o poro central (GOODENOUGH et al., 1996).
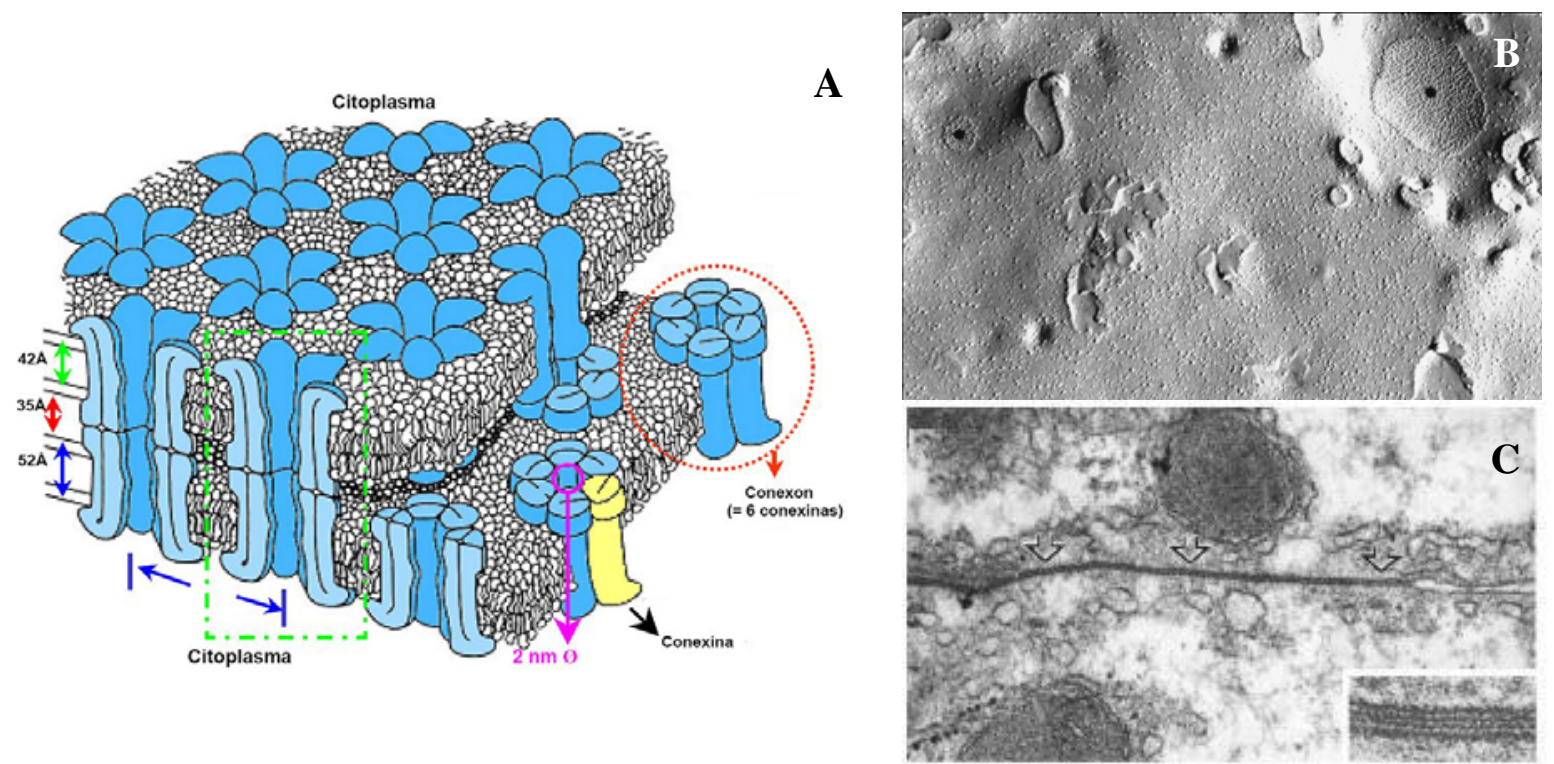

Fonte: (MAKOWSKI et al., 1977; KOJIMA et al., 2001a; SÁEZ et al., 2003)

Figura 13 - A) Modelo organizacional da placa juncional estabelecida a partir de estudos de microscopia eletrônica e de estudos de difração de raios X de junções gap no fígado de camundongos. Cada hemicanal ou conexon (circulo vermelho) é formado por seis subunidades de conexinas (representadas em amarelo/azul) delimitando um poro central e está estritamente associado a outro conexon na membrana adjacente. B) Microscopia eletrônica de varredura demonstrando as placas juncionais (*) na membrana de uma célula. C) Eletromicrografia demonstrando a junção comunicante do tipo gap (setas)

O cDNA que codifica as conexinas revela regiões de alta homologia e regiões com pequena ou nenhuma homologia, permitindo uma classificação segundo seus pesos moleculares. Sendo assim, a nomenclatura normalmente utilizada para a denominação das diferentes conexinas faz referência ao peso molecular da proteína (em $\mathrm{kDa}$ ), precedida da abreviação Cx (BEYER; PAUL; GOODENOUGH, 1987; YAMASAKI; NAUS, 1996). Quando existem mais de uma conexina com o mesmo peso molecular, estas proteínas recebem a adição de um número decimal, como ocorre, por exemplo, na diferenciação da 
Cx31 com a Cx31.1 (WILLECKE et al., 1991; HENNEMANN et al., 1992). Várias conexinas apresentam expressão tecido-específica, por outro lado, muitos tecidos apresentam expressão de diferentes conexinas, como apresentado no quadro 2 (YAMASAKI; NAUS, 1996).

\begin{tabular}{|c|c|}
\hline Conexina & Células \\
\hline Cx26 & $\begin{array}{l}\text { Hepatócitos, Células secretoras das glândulas endócrinas e } \\
\text { exócrinas, Determinados queratinócitos, Determinadas células } \\
\text { epiteliais }\end{array}$ \\
\hline Cx30 & Cérebro e Queratinócitos \\
\hline Cx30.3 & Células dos blastocistos; Determinados queratinócitos \\
\hline Cx31 & $\begin{array}{l}\text { Determinados queratinócitos; Células dos blastocistos; Células da } \\
\text { trofoectoderme placentária; Rins }\end{array}$ \\
\hline Cx32 & $\begin{array}{l}\text { Maioria dos epitélios; Hepatócitos; células secretoras das } \\
\text { glândulas exócrinas; epitélio folicular da tireóide; Rins; } \\
\text { Determinados neurônios; Oligodendrócitos; Células de Schwann }\end{array}$ \\
\hline Cx33 & Algumas células do testículo \\
\hline Cx36 & Neurônios \\
\hline Cx37 & $\begin{array}{l}\text { Determinadas células endoteliais; Determinados queratinócitos; } \\
\text { Células musculares cardíacas }\end{array}$ \\
\hline Cx40 & $\begin{array}{l}\text { Determinadas células endoteliais; Célula dos blastócitos; Células } \\
\text { do sistema de condução cardíaca; }\end{array}$ \\
\hline Cx43 & $\begin{array}{l}\text { Epitélio do cristalino e da córnea; Osteócitos; Astrócitos; } \\
\text { Leptomeninges; Leucócitos; Macrófagos; Células musculares } \\
\text { cardíacas; Trofoblastos; Células musculares lisas; Células } \\
\text { secretoras das glândulas endócrinas; células } \beta \text { pancreáticas; células } \\
\text { de Leydig; células de Sertoli; células tireoideanas; Determinados } \\
\text { queratinócitos; Blastócitos; Fibroblastos. }\end{array}$ \\
\hline Cx45 & $\begin{array}{l}\text { Células Musculares cardíacas; Células dos blastócitos; Células } \\
\text { epiteliais do pulmão, dos rins, do intestino; do cérebro; } \\
\text { Determinados queratinócitos; Osteócitos }\end{array}$ \\
\hline Cx46 & $\begin{array}{l}\text { Fibras do cristalino; Células musculares; Células de Schwann; } \\
\text { Células musculares cardíacas; Osteócitos }\end{array}$ \\
\hline Cx49 & Cristalino \\
\hline Cx50 & Fibras do cristalino e córnea \\
\hline Cx57 & $\begin{array}{l}\text { Coração, pulmão, Pele, Rins, Ovários, } \\
\text { Testículos, Intestino }\end{array}$ \\
\hline Cx60 & Teca interna e células cúmulos no ovário \\
\hline
\end{tabular}

Fonte: (YAMASAKI; NAUS, 1996)

Quadro 2 - Principais conexinas descritas e sua distribuição nos diferentes tipos celulares 
As conexinas podem interagir entre si, formando conexons homoméricos (formado por 6 conexinas iguais) ou heteroméricos (formados por 6 conexinas diferentes). Por sua vez, os conexons também podem interagir entre si, constituindo canais homotípicos (formado por conexons iguais) ou heterotípicos (formado por conexons diferentes) (Figura 14).

a

Connexin26 relative to the cell membrane

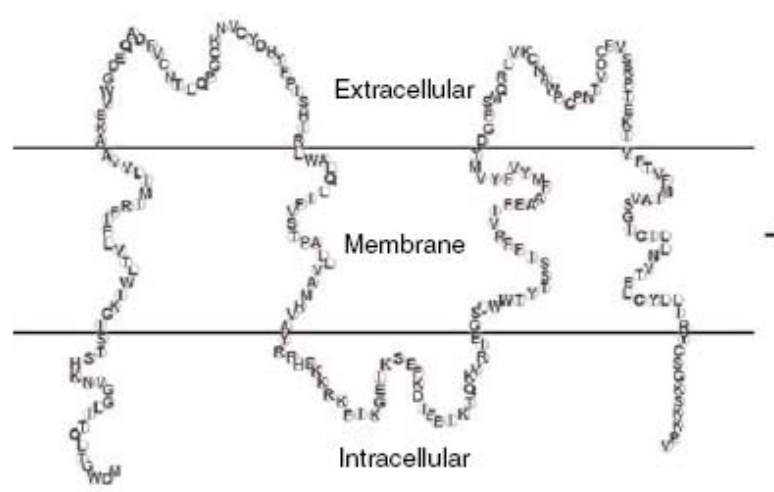

Connexin b

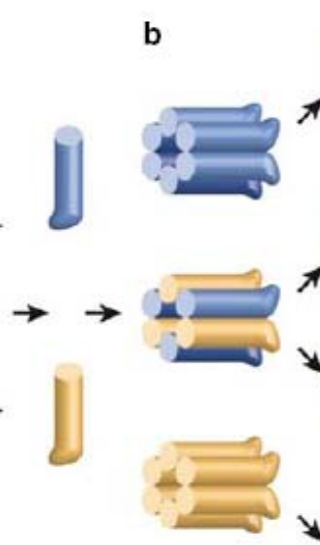

C

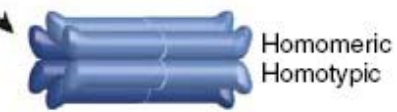

Gap junctions

Fonte: (MESE; RICHARD; WHITE, 2008)

Figura 14 - a) Representação estrutural da conexinas, demonstrando a presença de 4 domínios transmembrânicos, 2 alças extracelulares e 1 alça intracelular. b) Representação esquemática das possíveis organizações das conexinas para formar conexons homo e heteroméricos; e de conexons para formar canais homo e heterotípicos

A importância da determinação das conexinas constituintes de cada canal comunicante está relacionada com sua permeabilidade seletiva (Figura 15a e 15b). As junções gap possibilitam o livre trânsito de pequenas moléculas $(<1-2 \mathrm{kDa})$, metabólitos e mensageiros secundários, como $\mathrm{Na}^{+}, \mathrm{Ca}^{2+}$, AMP cíclico, inositol 1,4,5-trifosfato e outros (BRUZZONE; WHITE; PAUL, 1996; KING; BERTRAM, 2005). Sendo assim, as junções comunicantes do tipo gap desempenham um papel importante na regulação da homeostasia tecidual e em diferentes processos responsáveis pelo resgate desta homeostasia ou que são desencadeados 
em decorrência de danos a mesma, como, cicatrização e reparo tecidual, angiogênese, carcinogênese, controle da diferenciação e proliferação celular (YAMASAKI; NAUS, 1996; EVERT, 2002; CHANSON et al., 2005), dentre outros.
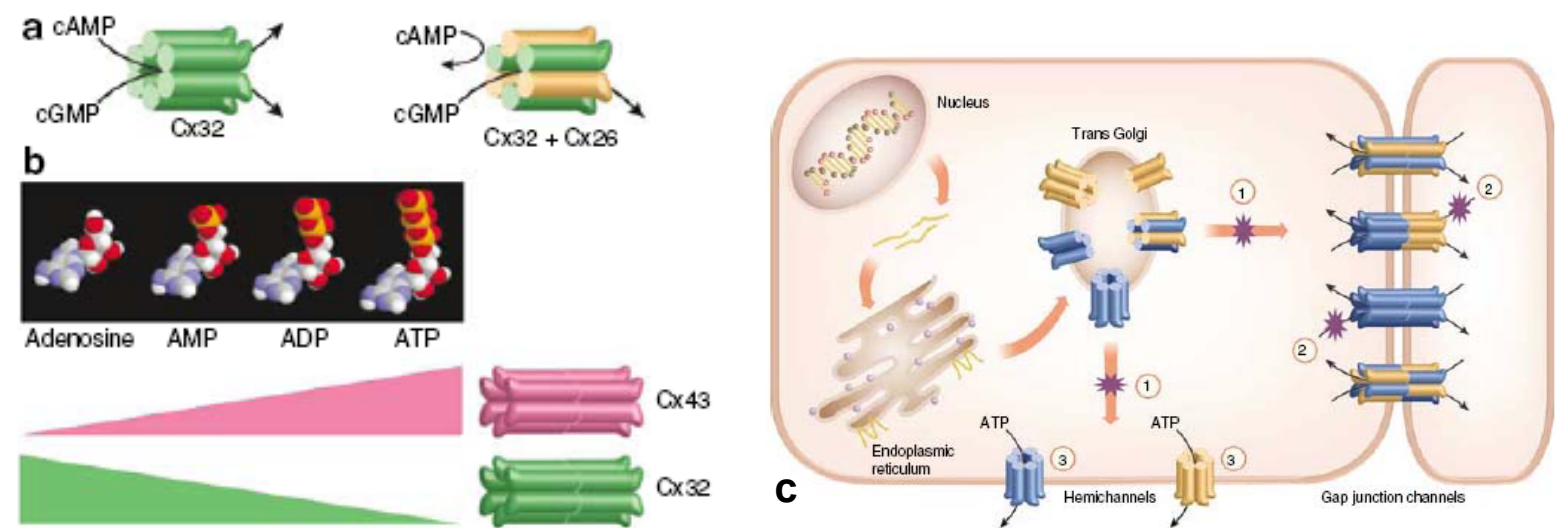

Fonte: (MESE; RICHARD; WHITE, 2008)

Figura 15 - Permeabilidade seletiva das junções gap formadas por diferentes conexinas. a) Canais formados por Cx32 são permeáveis para cAMP e cGMP (AMP e GMP cíclicos). No entanto, canais heterométricos formados por Cx32 e Cx26 apresentam redução na permeabilidade para o AMP cíclico. b) A molécula de adenosina apresenta maior permeabilidade em canais formados por $\mathrm{Cx} 32$, quando comparados aos canais formados por $\mathrm{Cx} 43$. No entanto, a adição de grupos fosfato extras à molécula de adenosina altera esta permeabilidade. c) Mutações nas conexinas podem alterar o seu transporte para a membrana (1), assim como a função comunicante dos canais (2)

Mutações patogênicas das conexinas podem afetar a formação e a funcionalidade dos canais comunicantes (Figura 15c) e estão relacionadas com diversas alterações e síndromes genéticas em animais e seres humanos (MESE; RICHARD; WHITE, 2008). No quadro 3 estão relacionadas as principais alterações genéticas das conexinas humanas e o fenótipo resultante em camundongos geneticamente modificados que sofreram a deleção dos dois genes alelos (camundongos knockout) para as conexinas. 


\begin{tabular}{|ccc|}
\hline Gene & Doença Humana & Fenótipo em Camundongo knockout \\
\hline Cx43 & $\begin{array}{c}\text { Síndrome da displasia } \\
\text { oculodentodigital (SDODD) }\end{array}$ & $\begin{array}{c}\text { Letalidade perinatal } \\
\text { (Dismorfogênese cardíaca) }\end{array}$ \\
\hline Cx46 & Catarata zonular pulverulenta 3 & Catarata nuclear zonular \\
\hline Cx37 & Predisposição à arteriosclerose & Esterilidade na fêmea \\
\hline Cx40 & Fibrilação atrial idiopática & Arritmia atrial \\
\hline Cx50 & Catarata zonular pulverulenta 1 & Catarata congênita, microftalmia \\
\hline Cx32 & Doença de Charcot- \\
& Marie-Tooth & Aumento da hepatocarcinogênese \\
\hline Cx26 & $\begin{array}{c}\text { Surdez sindrômica e não-sindrômica, } \\
\text { hiperqueratose palmo-plantar }\end{array}$ & Letalidade no 11 ${ }^{\text {o dia embrionário }}$ \\
\hline Cx31 & $\begin{array}{c}\text { Surdez sindrômica e não-sindrômica, } \\
\text { eritroqueratodermia variável (EQV) }\end{array}$ & Dismorfogênese transiente da placenta \\
\hline Cx30 & $\begin{array}{c}\text { Surdez não-sindrômica, Displasia } \\
\text { ectodérmica hidrótica }\end{array}$ & Audição insuficiente, ausência de \\
& alteração dérmicas \\
\hline
\end{tabular}

Fonte: (modificado de DOBROWOLSKI; WILLECKE, 2009)

Quadro 3 - Principais alterações genéticas relacionadas a mutações em genes que codificam diferentes conexinas em seres humanos, e o fenótipo destas mutações em camundongos knockouts

\subsection{CONEXINAS NO FÍGADO}

As conexinas 32 e 26 são as principais proteínas componentes das junções do tipo gap no fígado, localizadas na membrana plasmática dos hepatócitos (Figura 16), formando conexons homo ou heteroméricos (STUTENKEMPER et al., 1992; VINKEN et al., 2007). A Cx32 foi a primeira conexina a ser clonada, sendo dez vezes mais abundante no fígado de ratos e humanos do que a Cx26 (10:1), e ocupam cerca de 3\% da membrana plasmática (NICHOLSON et al., 1987; VINKEN et al., 2007). Em camundongos, esta proporção é de 2:1 (KOJIMA et al., 2001b). A expressão da Cx32 é uniformemente distribuída em todas as regiões do fígado, enquanto a Cx26 é preferencialmente expressa na região acinar periportal (KOJIMA et al., 1994). 


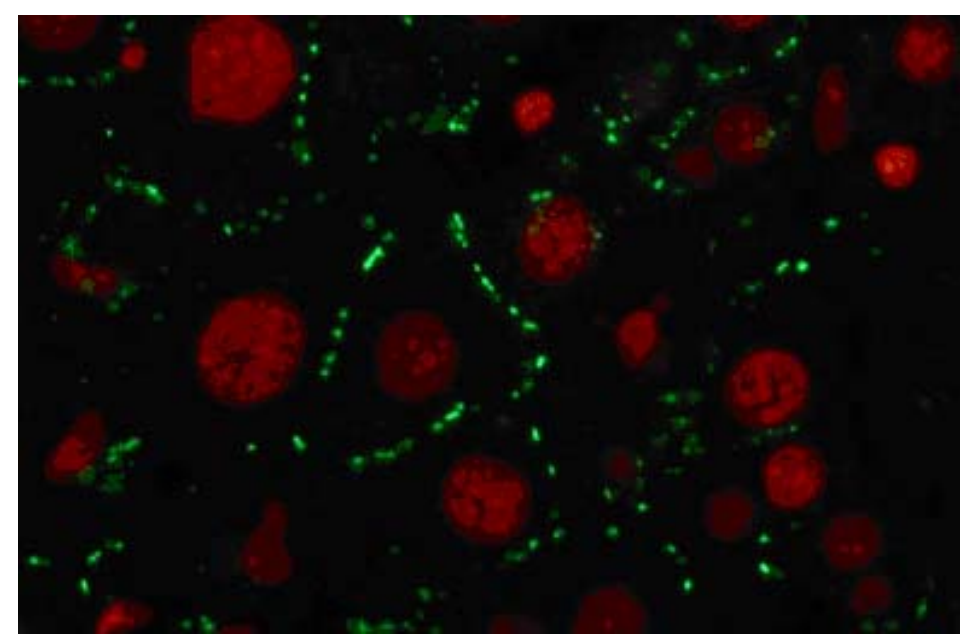

Figura 16 - Imunofluorescência demonstrando a presença da proteína Cx32 (pontos verdes) na membrana plasmática de hepatócitos. Reação de imunofluorescência amplificada pelo sistema TSA. Contra-coloração nuclear com iodeto de propídeo (vermelho). Fígado normal de camundongo, 400x. Autoria: Cogliati B

As células endoteliais das artérias e veias hepáticas expressam Cx37 e Cx40, enquanto a maioria das células não-parenquimatosas expressam Cx43 (VINKEN et al., 2007). O primeiro relato sobre a comunicação intercelular mediada pelas junções gap nas células estreladas hepáticas (HSC), antigamente conhecidas como células de Ito ou lipócitos, foi realizado por Greenwell et al. (1993). Anos mais tarde, Fisher et al. (2005) demonstraram que as HSCs quiescentes (ou seja, ainda armazenadoras de vitamina A em lipossomos) expressam Cx43 e uma pequena quantidade de Cx26. Quando estas células são ativadas em miofibroblastos, apresentam aumento na expressão da $\mathrm{Cx} 43$ com localização preferencial na superfície celular, e aumento na expressão de Cx26, porém localizada ao redor do núcleo.

González et al. (2002) demonstraram um aumento transitório da expressão de Cx43 no fígado de ratos submetidos a diferentes modelos colestáticos. Os autores sugeriram que este evento ocorreu por um possível aumento no número de células de Kupffer infiltradas nos espaços perissinusoidais. No entanto, apenas em 2007, Eugenín et al. determinaram que condições inflamatórias in vivo e in vitro induzem a expressão de Cx43 entre as células de Kupffer ativadas, estabelecendo uma comunicação intercelular funcional. Também foi demonstrado que os colangiócitos expressam $\mathrm{Cx} 43 \mathrm{em}$ modelos in vivo e in vitro (BODE et al., 2002), assim como as células ovais (ZHANG; THORGEIRSSON, 1994) e as células mesoteliais da cápsula de Glisson (VINKEN et al., 2007). 
A precisa determinação das conexinas e do funcionamento da comunicação intercelular nas células endoteliais sinusoidais (SEC) ainda necessitam de mais estudos. Alguns relatos ocasionais descrevem a expressão da Cx26 nas SECs, com baixíssima expressão de Cx43 ou Cx32 (FISHER et al., 2005; VINKEN et al., 2007). No quadro 4 está descrita a expressão das conexinas e as respectivas células hepáticas.

\begin{tabular}{|cc|}
\hline Células Hepáticas & Conexinas (Cx) \\
\hline Hepatócitos & 32 e 26 \\
Colangiócitos & 43 \\
Células estreladas (Ito) & 43 e 26 \\
Células de Kupffer & 43 \\
Células endoteliais sinusoidais & $26,43 / 32(?)$ \\
Células endoteliais de vasos e artérias & 37 e 40 \\
Células mesoteliais (cápsula de Glisson) & 43 \\
\hline
\end{tabular}

Fonte: (modificado de VINKEN et al., 2007)

Quadro 4 - Expressão das conexinas nos diferentes tipos celulares hepáticos

\subsection{CONEXINAS NAS DOENÇAS HEPÁTICAS CRÔNICAS}

A meia vida das conexinas 32, 26 e 43 é de, aproximadamente, 2 a 5 horas. Assim, a comunicação intercelular depende de muitos fatores de controle sobre a dinâmica de síntese e degradação destas proteínas, os quais podem ser comprometidos por disfunções hepáticas associadas a doenças crônicas, inflamatórias ou neoplásicas (NAKASHIMA et al., 2004).

Estudos realizados em fígados de pacientes com cirrose alcoólica demonstraram que a expressão da Cx32 diminuiu significativamente em relação aos fígados normais, apresentando ainda redução gradual concomitante ao progresso da doença (NAKASHIMA et al., 2004). Resultados semelhantes foram descritos por Yamaoka et al. (1995, 2000), onde também analisaram pacientes com hepatite viral crônica e carcinoma hepatocelular (HCC), demonstrando redução semelhante da Cx32. Dessa maneira, a comunicação intercelular através das junções gap apresenta-se alterada nas doenças hepáticas, agravando-se com a 
cronicidade. Outro aspecto relevante na distribuição desta conexina nas lesões hepáticas crônicas está relacionado ao fenômeno conhecido como internalização, fazendo com que a Cx32 apresente uma localização aberrante, geralmente citoplasmática. NAKASHIMA et al. (2004) demonstraram que $88 \%$ dos pacientes com cirrose, $67 \%$ com hepatite e $100 \%$ com HCC apresentaram internalização da Cx32, prejudicando sua função comunicante.

A Cx32 também apresentou redução em modelos experimentais de doenças hepáticas crônicas. Nakata et al. (1996) demonstraram que o fígado de ratos, submetidos à administração crônica de tetracloreto de carbono $\left(\mathrm{CCl}_{4}\right)$, apresentou redução de $37 \%$ na expressão de Cx32. Esta redução ainda prosseguiu com valores inferiores ao grupo controle durante um mês após o término da intoxicação, retornando ao normal após 60 dias da última aplicação. No entanto, os níveis do RNAm da Cx32 destes animais permaneceram constantes, o que os autores atribuíram a uma provável mudança pós-transcricional (causando diminuição da síntese protéica) ou a um transtorno nos controles pós-translacionais. Rodrigues et al. (2009) analisaram ratos com fibrose hepática induzida pela dimetilnitrosamina e observaram diminuição da expressão gênica da Cx32 e sua distribuição aberrante no citoplasma dos hepatócitos. No entanto, não houve diferença na expressão protéica, provavelmente devido a uma meia-vida mais longa das conexinas localizadas no citoplasma.

Yamaoka et al. (2000) sugerem que a diminuição da expressão da Cx32 em fígados portadores de doenças crônicas pode estar relacionada ao processo de regeneração, que normalmente ocorre em conjunto à injúria hepática (MANGNALL et al., 2003). Neste processo, ocorre decréscimo na expressão gênica da $\mathrm{Cx} 32$, provocando alterações no processo de reparação tecidual (NEVEU et al., 1995; FUJIMOTO, et al., 1997). Dagli et al. (2004) realizaram hepatectomia parcial em camundongos transgênicos, que expressam um mutante da Cx32 somente no fígado, e observaram retardo no pico de hepatócitos em fase $\mathrm{S}$ do ciclo celular. Os autores sugeriram que estes efeitos foram decorrentes da menor difusão de mensageiros secundários, o que ressalta a importância das junções comunicantes nos processos proliferativos no fígado.

Diversos estudos relacionados à carcinogênese também demonstraram redução das conexinas, indicando-as como genes supressores de tumores e de grande relevância nos eventos de transformação celular (TEMME et al., 1997; OMORI et al., 2001; MA et al., 2000, 2002; EVERT et al., 2002).

Estudos relacionados ao carcinoma hepatocelular humano revelaram diminuição na expressão das Cx32 e Cx43 e de seus respectivos mRNA, demonstrando o envolvimento destas proteínas na progressão neoplásica (MA et al., 2002). No entanto, a participação da 
Cx43 no fígado portador de doenças crônicas não foi estabelecida (YAMAOKA et al., 2000). Experimento de hepatocarcinogênese utilizando o carcinógeno dietilnitrosamina (DEN) em camundongos deficiente em $\mathrm{Cx} 43\left(\mathrm{Cx} 43^{+/}\right)$demonstrou não haver diferença na formação de neoplasias em relação aos animais selvagens (wild-type - $\mathrm{Cx} 43^{+/+}$) (GUERRA, 2003). No entanto, animais knockout ou deficientes em $\mathrm{Cx} 32\left(\mathrm{Cx} 32^{-/-}\right.$e $\left.\mathrm{Cx} 32^{\mathrm{Y} /-}\right)$, submetidos ao mesmo processo neoplásico, apresentaram aumento da susceptibilidade ao HCC (TEMME et al., 1997), sugerindo a significativa participação desta conexina na supressão tumoral.

Seguindo esta linha, Oloris et al. (2007) avaliaram o desenvolvimento de granulomas hepáticos, induzidos por Schistosoma mansoni, em camundongos deficientes em Cx43. Estes animais apresentaram maior deposição de fibras colágenas ao redor dos granulomas em relação aos animais wild-type $\left(\mathrm{Cx} 43^{+/+}\right)$. Estes resultados demonstraram a participação da Cx43 no controle do processo fibrótico, uma vez que os camundongos deficientes em Cx43 apresentaram maior deposição de colágeno no fígado mediante injúria celular.

\subsection{CONEXINAS E CÉLULAS ESTRELADAS HEPÁTICAS}

As células estreladas hepáticas (HSC), também conhecidas como células de Ito ou lipócitos, vêm sendo estudadas há mais de duas décadas e apresentam uma importante participação na fisiopatogênese da fibrose nas doenças hepáticas crônicas. Quando ativadas em miofibroblastos, estas células são as principais responsáveis pela produção e degradação de componentes da matriz extracelular (MEC) hepática localizada nas regiões perissinusoidais ou nos septos fibrosos (FRIEDMAN, 2008b). Como mencionado anteriormente, as HSCs ativadas expressam quantidade significativa de Cx43 e são capazes de estabelecerem uma eficiente comunicação apenas entre si (FISHER et al., 2005). Os fibroblastos portais também podem se diferenciar em miofibroblastos e estão envolvidos no estabelecimento da fibrose periportal (GUYOT et al., 2006). No entanto, inexistem estudos relacionados à comunicação intercelular do tipo gap em fibroblastos portais.

Uyama et al. (2003), avaliando a influência da comunicação intercelular na fibrose hepática, isolaram e trataram células estreladas de ratos com drogas inibidoras das junções comunicantes do tipo gap. Os autores demonstraram que as células tratadas com carbenoloxona, um potente inibidor das junções gap e usado no tratamento de úlceras gástricas, apresentaram inibição do processo de ativação em miofibroblastos. Ainda, esta 
droga inibiu a síntese de DNA das células ativadas e promoveu uma menor expressão gênica do colágeno tipo I. Estes resultados indicaram a importante participação da comunicação intercelular no controle da homeostasia e metabolismo das células estreladas hepáticas.

Lim, Maubach e Zhuo (2009) avaliaram a expressão da Cx43 em células estreladas submetidas a diferentes tratamentos. Primeiramente, os autores trataram as células com TGF $\beta$-1, uma citocina com importante ação pró-fibrogênica, e observaram diminuição na expressão gênica da $\mathrm{Cx} 43$, com aumento em sua fosforilação e conseqüente redução da comunicação intercelular. No mesmo trabalho, utilizando a técnica de interferência por RNA para o gene da $\mathrm{Cx} 43$, os autores perceberam que a menor expressão de $\mathrm{Cx} 43$ ocasionou redução na proliferação celular. Assim, este estudo demonstrou que a expressão da Cx43 nas HSCs pode ser modulada pelos níveis de TGF $\beta-1$ e que a expressão da Cx43 interfere diretamente na proliferação desta células.

Os estudos aparentemente têm demonstrado a importância da Cx43 em uma das células mais importantes no desenvolvimento da fibrose hepática. Como demonstrado acima, a redução da sua expressão reduziu a proliferação e ativação das células estreladas e, por conseqüência, a deposição de colágeno. Como será apresentado a seguir, já foram realizados muitos avanços em relação à função das junções comunicantes do tipo gap em processos de reparação tecidual e fibrogênese em outros órgãos ou tecidos.

\subsection{EXPRESSÃO DE CONEXINAS EM FIBROBLASTOS DÉRMICOS NA CICATRIZAÇÃO E REPARAÇÃO TECIDUAL}

A expressão e distribuição das conexinas podem variar de acordo com os estágios de maturação e reparação tecidual da epiderme (MAN et al., 2007). A reparação tecidual é um evento complexo e altamente ordenado, onde coexistem inúmeros processos fisiológicos e representa um processo onde a proliferação celular ocorre para restaurar a arquitetura tecidual normal com tecido conjuntivo (DAGLI; HERNANDEZ-BLAZQUEZ, 2007). Inicialmente, ocorre a indução de um processo inflamatório em resposta ao dano inicial, com remoção do tecido danificado ou morto. Ao término deste processo de "limpeza" da área lesada, inicia-se a proliferação e migração de células teciduais parenquimatosas e conjuntivas, estabelecendo uma barreira física sobre a lesão. Então, um tecido de aparência rósea, liso, granular é formado na superfície das feridas, conhecido como tecido de granulação. Este tecido 
caracteriza-se pela intensa angiogênese e proliferação de fibroblastos. Esses novos vasos permitem a passagem de proteínas e células vermelhas para dentro do espaço extravascular, tornando-o edemaciado. Depois, inicia-se a fase de remodelamento tecidual com a síntese e deposição de proteínas da matriz extracelular, principalmente colágeno. A fase posterior refere-se ao processo de restauração tecidual, com contração da ferida e aquisição de resistência (KUMAR et al., 2005).

$\mathrm{Na}$ pele normal, os fibroblastos são quiescentes e apresentam-se distribuídos esparsamente na MEC, porém modificações estruturais e bioquímicas ocorrem nestes fibroblastos durante a reparação tecidual. Primeiramente, estas células migram para o sítio da injúria, começam a se multiplicar e iniciam a produção de elementos da matriz extracelular, principalmente colágeno. Assim é formado o tecido de granulação com a deposição de colágeno tipo III, e outras moléculas, permitindo a formação da neoderme. Nesta fase, o citoesqueleto dos fibroblastos é composto por finos microfilamentos (MOYER; EHRLICH, 2003). No entanto, Varga, Brenner e Phan (2005) demonstraram que, após duas semanas de cicatrização em roedores, os fibroblastos diferenciam-se em miofibroblastos e iniciam a produção de fibras contrácteis, dando início ao processo de compactação e contração tecidual. Nesta etapa, o citoesqueleto dos miofibroblastos é composto por fibras de estresse agregados aos microfilamentos, juntamente com a expressão da alfa-actina de músculo liso ( $\alpha$-SMA) (MOYER; EHRLICH, 2003). Durante a transição da MEC provisória, o colágeno é remodelado mediante uma grande variedade de fatores de crescimento e citocinas, tais como: TGF- $\beta 1$, PDGF, EGF, FGF, IL-1 e TNF- $\alpha$. Sob a influência destes fatores, o excesso de colágeno tipo III produzido é substituído pelo tipo I, promovendo a resolução da cicatriz (VARGA; BRENNER; PHAN, 2005).

Todo este processo de remodelamento da matriz extracelular durante a cicatrização acontece devido a participação de diversas moléculas bioativas, como os fatores de crescimento e citocinas citados acima, além de metaloproteinases da matriz (MMP -1, -2, -3, $8,-9,-10,-13$ e -14) e seus inibidores (TIMP-1, -2 e -3) (MANUEL; GAWRONSKAKOZAK, 2006). Na reparação tecidual é necessário que ocorra síntese e deposição de matriz extracelular, as quais são realizadas pelos miofibroblastos. E os próprios miofibroblastos, juntamente com os queratinócitos, neutrófilos e macrófagos, são responsáveis pela liberação de moléculas que realizam a degradação e organização desta matriz recém-formada. Após o término das funções de remodelamento tecidual, os miofibroblastos entram em apoptose, o que exigi um sistema eficiente de comunicação intercelular para que não ocorram distúrbios no local (MOYER; EHRLICH, 2003). 
A adesão e comunicação celular são componentes essenciais na diferenciação e remodelação tecidual (KO et al., 2000). Os fibroblastos e as células endoteliais apresentam abundante expressão de Cx43 (EHRLICH; DIEZ, 2003).

Moyer e Ehrlich (2003) demonstraram que fibroblastos dermais humanos, tratados com hialurano (HÁ), apresentaram aumento da densidade de Cx43 na membrana plasmática e maior capacidade de comunicação intercelular funcional. O HA é um componente estrutural do tecido conjuntivo, assim como um mediador de diversas funções celulares, além de estar envolvido diretamente na modulação da comunicação intercelular via junções gap (NAGY et al., 1996). Ainda, o HA está relacionado com a organização das fibrilas de colágeno recémsintetizadas pelos fibroblastos presente no tecido de granulação (IOCONO et al., 1998). Sendo assim, um processo de comunicação mais eficiente consegue promover uma melhor organização das fibrilas de colágeno recém-depositadas na ferida tecidual, levando a uma cicatrização bem sucedida esteticamente, neste caso, estimulado pela ação do HA.

Kretz et al. (2003) avaliaram o processo de cicatrização tecidual na cauda de animais deficientes em Cx43 e demonstraram o fechamento precoce da ferida cutânea, o qual foi relacionado à maior proliferação e mobilização dos queratinócitos durante a reparação tecidual. Até o momento sabia-se da importância da $\mathrm{Cx} 43$ no processo de reparação tecidual, porém seus mecanismos permaneciam desconhecidos.

$\mathrm{Na}$ tentativa de elucidar estes mecanismos, foram realizados diversos modelos de cicatrização e reparação tecidual em animais de laboratório tratados com uma terapia antisense (AS) para $\mathrm{Cx} 43$. Esta terapia baseia-se em um gel de uso tópico, composto por oligonucleotídeos que inibem, no local da aplicação, a tradução da molécula alvo por complementariedade de ligação à molécula de RNA mensageiro, neste caso, da Cx43 (KREUZER; MASSEY, 2002). Um dos primeiros trabalhos foi realizado por Qiu et al. (2003), onde os autores demonstraram que a aplicação desta terapia promove a inibição local da Cx43 na ferida cutânea, ocasionando o fechamento precoce da lesão, com significativa redução na deposição do tecido de granulação e conseqüente redução da cicatriz e de sua distorção. Posteriormente, Coutinho et al. (2005) avaliaram a recuperação de lesões ocasionadas por queimaduras e tratadas com esta mesma terapia AS. Da mesma maneira, os autores observaram maior proliferação das células epiteliais, com fechamento precoce da ferida e menor quantidade de tecido cicatricial nos animais tratados com a terapia AS (Figura 17). Estes resultados indicaram uma importante participação da $\mathrm{Cx} 43$ e, consequentemente, da comunicação intercelular, no controle e ativação das funções celulares dos fibroblastos 
dermais, podendo inclusive ser utilizada como alvo terapêutico em certos distúrbios da cicatrização ou outras terapias teciduais.

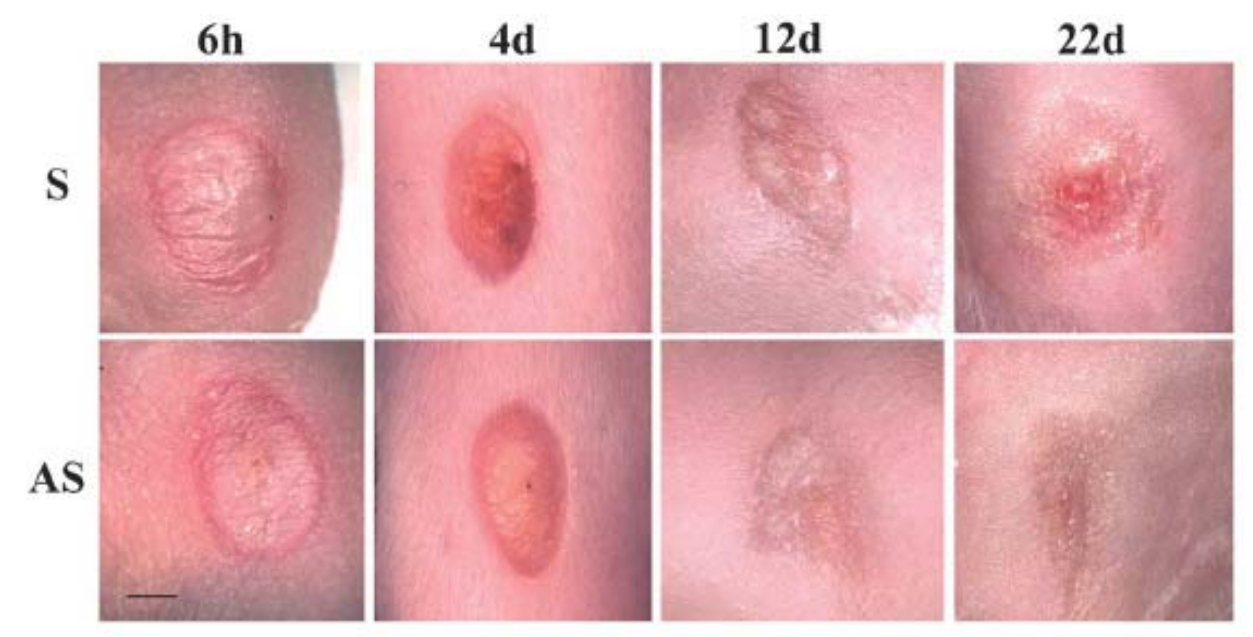

Fonte: (COUTINHO et al., 2005)

Figura 17 - Modelo de cicatrização após lesão térmica em camundongos, tratados com terapia antisense (AS) para Cx43. Observe que os animais tratados apresentam uma cicatrização cutânea mais eficiente, com maior contração e remodelamento da matriz extracelular

Seguindo a mesma linha de pesquisa, Mori et al. (2006) avaliaram animais com feridas cutâneas tratadas topicamente com esta terapia antisense para $\mathrm{Cx} 43$. Os autores demonstraram aceleração na reparação tecidual, aumento na proliferação de queratinócitos, aumento na migração de fibroblastos na ferida e in vitro, assim como aumento na deposição de matriz colágena. Os autores também observaram decréscimo na infiltração de neutrófilos e redução do recrutamento de macrófagos, proporcionando uma significativa melhora na reparação tecidual. Resultados semelhantes foram observados em fibroblastos dermais tratados com drogas inibidoras da funcionalidade das junções comunicantes, aumentando sua taxa de migração celular (WRIGHT et al., 2009). Dessa maneira, uma menor expressão de conexina 43 na ferida cutânea pode interferir na cicatrização da pele, neste caso com resultados benéficos devido a maior quantidade de fibroblastos no local, e maior deposição de colágeno, conferindo o fechamento precoce da lesão.

Considerando os resultados relacionados à diminuição da expressão de $\mathrm{Cx} 43$ ou da funcionalidade da comunicação intercelular em diversos modelos animais, alguns autores relataram a participação destes mecanismos nas principais doenças humanas relacionadas a 
problemas de cicatrização cutânea, como nas cicatrizes hipertróficas e queloídes (LU et al., 2007) ou nas feridas de pacientes diabéticos (ABDULLAH et al., 1999; BAJPAI et al., 2009).

Lu et al. (2007) demonstraram que fibroblastos provenientes de cicatrizes quelóides ou hipertróficas apresentaram quantidade muito menor de $\mathrm{Cx} 43$ em relação a fibroblastos oriundos de pele normal. Estes resultados indicaram a importância da comunicação intercelular no controle do balanço entre a proliferação e apoptose dos fibroblastos na pele, assim como no controle da produção de matriz extracelular. Por outro lado, pacientes diabéticos apresentaram um grande problema relacionado à dificuldade de cicatrização de feridas cutâneas. As chamadas úlceras diabéticas são caracterizadas pelo atraso na contração da ferida, menor migração de fibroblastos, deposição de matriz extracelular e síntese de colágeno (BAJPAI et al., 2009). Assim, Abdullah et al. (1999) avaliaram fibroblastos provenientes de pacientes diabéticos e constataram uma menor funcionalidade da comunicação intercelular, porém as quantidades de $\mathrm{Cx} 43$ não foram modificadas. Ratos diabéticos induzidos experimentalmente apresentam expressão anormal das conexinas dérmicas e epidérmicas. Após lesão tecidual, estes animais apresentaram retardo na reepitelização das feridas e expressão anormal da Cx43 na epiderme das bordas da ferida (WANG et al., 2006).

Segundo Dagli e Hernandez-Blazquez (2007), a mudança na expressão das conexinas é a chave para os eventos de reparação tecidual. Durante sua progressão, os fibroblastos sofrem numerosas alterações fenotípicas, incluindo alterações em seu citoesqueleto, transdiferenciação em miofibroblastos e, finalmente, apoptose. Sendo assim, acredita-se que a sincronização de todos estes eventos fenotípicos dos fibroblastos presentes durante a reparação tecidual necessite de um eficiente sistema de comunicação intercelular, mediado por diversos fatores de crescimento e citocinas (MOYER; EHRLICH, 2003).

Ainda, os resultados apresentados e relacionados ao funcionamento dos fibroblastos e miofibroblastos demonstraram a importante participação da comunicação intercelular e, principalmente da conexina 43, na reparação tecidual cutânea. Este fato deve-se ao aumento na deposição de colágeno e matriz extracelular no local da injúria, ocasionando o fechamento precoce da ferida cutânea. No entanto, este mesmo mecanismo poderia ocorrer em outros órgãos? Seria igualmente benéfico? 


\subsection{EXPRESSÃO DE CONEXINAS EM FIBROBLASTOS NÃO-DÉRMICOS E OUTRAS CÉLULAS PRODUTORAS DE COLÁGENO}

Os fibroblastos cardíacos, além da manutenção da matriz extracelular no coração, secretam diversos fatores de crescimento e citocinas que modulam a atividade de fibroblastos e cardiomiócitos adjacentes. Após o infarto do miocárdio, estes fibroblastos são modificados em miofibroblastos e são responsáveis pela cicatrização do tecido afetado. A comunicação intercelular pode ocorrer entre os mio/fibroblastos, assim como entre estas células e o cardiomiócitos. O distúrbio nos mecanismos de comunicação entre estas células pode afetar algumas funções dos miofibroblastos, como contração da cicatriz e formação do colágeno (CHILTON; GILES; SMITH, 2007).

Fibroblastos cardíacos isolados de camundongos expressam Cx43 e Cx45, e apresentam importante participação no remodelamento tecidual pós-infarto, assim como na propagação de estímulos elétricos pela discreta comunicação intercelular com os cardiomiócitos. Experimento realizado em camundongos deficientes em $\mathrm{Cx} 43\left(\mathrm{Cx} 43^{+/}\right)$ demonstrou que os fibroblastos cardíacos apresentaram maior proliferação celular in vitro quando comparado aos fibroblastos normais. Por outro lado, fibroblastos com super-expressão de Cx43 apresentaram redução na proliferação celular. Estes resultados demonstraram uma relação inversamente proporcional entre a expressão de Cx43 e a proliferação celular, comprovando sua participação na manutenção da homeostasia e funcionalidade dos fibroblastos cardíacos (ZHANG et al., 2008). No entanto, aparentemente estes resultados são célula-específicos, pois nem todos os tipos celulares se comportam da mesma maneira.

Asazuma-Nakamura et al. (2009) demonstraram que, além da ação anti-proliferativa, a expressão da Cx43 está diretamente relacionada com a diferenciação dos fibroblastos cardíacos em miofibroblastos. Os autores isolaram fibroblastos murinos e trataram com terapia antisense para $\mathrm{Cx} 43$, observando inibição na expressão de $\alpha$-SMA, marcador da diferenciação celular em miofibroblastos, com provável participação da sinalização via TGF $\beta$-1. Estes resultados indicaram que a expressão da $\mathrm{Cx} 43$ regula a diferenciação dos fibroblastos cardíacos e, conseqüentemente, pode influenciar no processo de cicatrização e reparação tecidual no coração. Nakano et al. (2008) observaram resultados semelhantes em córneas tratadas com terapias anti-Cx43 e submetidas à injúria celular, onde os miofibroblastos corneanos sofreram inibição da diferenciação endotelial-mesenquimal e redução do seu número. Os autores demonstraram aceleração no processo de reparação 
tecidual pelo aumento na proliferação das células do endotélio corneano, como descrito na cicatrização dérmica.

A ativação e proliferação dos fibroblastos pulmonares formando agregados focais são eventos importantes no estabelecimento da fibrose pulmonar idiopática (FPI), levando à excessiva deposição de componente da matriz extracelular. Estudos com fibroblastos pulmonares derivados de pacientes portadores de FPI apresentaram menor expressão gênica da Cx43, associada à menor capacidade funcional de comunicação intercelular avaliada por citometria de fluxo (TROVATO-SALINARO et al., 2006). Estes resultados demonstraram que o distúrbio da comunicação intercelular pode favorecer a proliferação desordenada dos fibroblastos pulmonares, favorecendo a síntese de matriz extracelular. Resultados semelhantes foram descritos em paciente portadores de cicatrizes quelóides ou hipertróficas (LU et al., 2007).

Nos tendões, os fibroblastos são conhecidos como tenócitos e apresentam expressão das conexinas 32 e 43. Os tenócitos são responsáveis pela síntese, deposição e remoção dos componentes da MEC, principalmente após lesões ou ruptura nos tendões. Waggett, Benjamin e Ralphs (2006) isolaram tenócitos de galinhas e trataram com drogas inibidoras da formação das junções gap ou com terapia antisense para as conexinas 43 e 32 . Neste trabalho, os autores cultivaram as células primárias em matrizes especiais que permitia a aplicação de forças tensoras, estimulando a produção de colágeno. Após tratamento para bloqueio geral das junções gap, os tenócitos em descanso ou submetidos à tensão mecânica apresentaram redução na produção de colágeno. No entanto, ao analisarem a inibição de conexinas específicas, os autores encontraram resultados distintos para cada molécula. A inibição da Cx32 ocasionou aumento da produção de colágeno nas células em descanso ou tensionadas. Em contrapartida, a redução na expressão de Cx43 promoveu aumento na produção de colágeno pelos tenócitos apenas após tensão mecânica. Estes resultados indicaram uma importante participação da $\mathrm{Cx} 43$ como um potencial inibidor da produção de colágeno após injúria no tendão. Estes resultados são semelhantes aos apresentados em outros órgãos e tecidos, os quais também apresentaram maior deposição de colágeno durante o processo de cicatrização tecidual em resposta à redução na expressão da $\mathrm{Cx} 43$.

A comunicação intercelular via junções gap estão envolvidas em diversas funções metabólicas no tecido ósseo e possuem especial importância na sinalização celular durante o desenvolvimento, diferenciação embrionária e formação do esqueleto (SANCHES et al., 2009). As principais conexinas presentes no tecido ósseo são a $\mathrm{Cx} 43$ (presente em condrócitos, osteoblastos, osteócitos e osteoclastos), Cx45 e Cx46 (presentes apenas nos 
osteoblastos) (STAINS; CIVITELLI, 2005). Experimentos realizados in vivo e in vitro demonstraram um atraso no processo do desenvolvimento ósseo em camundongos deficientes em $\mathrm{Cx} 43$, sendo que os osteoblastos $\mathrm{Cx} 43^{-/-}$apresentaram menor deposição de colágeno tipo I in vitro (LECANDA, 2000). Estes mesmos resultados foram corroborados em um recente trabalho, onde se observou menor deposição de colágeno durante o desenvolvimento ósseo

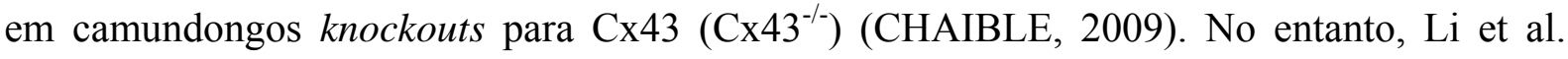
(2006) demonstraram que não houve alteração na expressão gênica de colágeno tipo I em uma linhagem de células osteoblásticas humanas (hFOB), após transfecção com Cx43 antisense, indicando que esta conexina não apresenta função crítica na regulação do colágeno durante a diferenciação osteoblástica desta linhagem celular.

A arteriosclerose é uma doença crônica imuno-mediada e umas das principais causas de morte na população adulta. É um processo multifatorial, inicialmente caracterizado pelo acúmulo de macrófagos e linfócito $\mathrm{T}$ contendo lipídeos na região da íntima subendotelial de vasos arteriais. Na seqüência, ocorrem lesões compostas por células espumosas, proliferação de células musculares lisas (SMC) e deposição de matriz extracelular, formando os arteromas (LUSIS, 2000). Todo este processo exige um complexo mecanismo de comunicação intercelular mediado por conexinas para coordenar a regulação entre as células sanguíneas e as células presentes na parede dos vasos arteriais (KWAK et al., 2003). Células endoteliais expressam Cx37, Cx30 e Cx43, enquanto as SMCs vasculares expressam Cx43 (YEH et al., 1998). Kwak et al. (2003) mostraram que camundongos deficientes em Cx43 apresentaram diminuição no desenvolvimento de lesões da arteriosclerose, com redução no número de células inflamatórias associadas ao arteroma. No entanto, estes mesmos animais apresentaram maior quantidade de SMCs na lesão, e consequentemente, maior deposição de colágeno intersticial (produzido pelas SMCs). Além de apresentarem aumento na espessura da cápsula fibrosa sobre a lesão. Assim, os autores deduziram que uma lesão com menor conteúdo lipídico e mais fibrosa torna-se mais estável e com menor probabilidade de rompimento, o que significa menor risco de infarto agudo do miocárdio, entre outras complicações associadas.

Entretanto, contradizendo o estudo anterior, Rama et al. (2006) avaliaram os efeitos da citocina TGF $\beta$-1 em células musculares lisas (SMCs) proveniente da aorta humana. Os autores observaram que esta citocina promove aumento na expressão da $\mathrm{Cx} 43$ nestas células, assim como na funcionalidade dos canais comunicantes. Ainda, estas células apresentaram mudanças em sua morfologia, aumento na expressão de marcadores de ativação e na contratilidade celular e maior síntese de colágenos tipo I e III, independentemente da proliferação celular. Ou seja, este experimento demonstrou que células com maior expressão 
de conexina 43 apresentam maior síntese de colágeno, apesar de ser contraditório em relação ao seu estado de ativação. As SMCs normalmente são consideradas como sintetizadoras de MEC quando perdem seu fenótipo contrátil, ao contrário do que aconteceu neste trabalho.

Todos os trabalhos apresentados nesta seção demonstraram a influência da comunicação intercelular em processos de cicatrização, reparação tecidual ou deposição de matriz extracelular em diversos tecidos e órgãos. Diante dos diferentes resultados obtidos em cada tipo celular, são observados mecanismos célula-específicos em relação ao controle da síntese e degradação da MEC. Ou seja, o mecanismo predominante em um determinado tipo celular pode não ser válido para outros. De maneira geral, dependendo da aplicação clínica, a modulação na comunicação intercelular traz um efeito benéfico para o indivíduo, seja pela maior ou menor deposição de colágeno.

\subsection{CONEXINAS E PROLIFERAÇÃO CELULAR}

A proliferação celular é um processo importante na reprodução, crescimento e renovação das células e ocorre em diversas situações durante a vida embrionária, fetal e adulta de um indivíduo. Em muitos casos, a proliferação ocorre em reposta ao aumento da morte celular, como em situações que envolvem dano tecidual, ou em resposta a estímulos hormonais ou fatores de crescimento. Diversos estudos demonstraram uma relação inversamente proporcional entre a comunicação intercelular e a proliferação celular em tumores, resultando na importante função das conexinas e junções gap na inibição do crescimento celular anormal (LOEWENSTEIN; KANNO, 1966; LOEWENSTEIN; ROSE, 1992; MESNIL, 2005). Sendo assim, foi estabelecido o conceito de que as junções gap são importantes para a transmissão de sinais regulatórios positivos ou negativos para as células adjacentes, controlando assim o crescimento celular. Ou seja, na ausência da comunicação as células tumorais não recebem os sinais intercelulares para parada de ciclo ou morte celular, por exemplo (TROSKO; RUCH, 1998).

Além de diversos estudos relacionados aos processos tumorais, muitos autores avaliaram a capacidade de comunicação intercelular e sua redução em processos patológicos não tumorais. De maneira geral, observou-se o mesmo comportamento apresentado pelas neoplasias (DAGLI; HERNANDEZ-BLAZQUEZ, 2007) e apresentados nos itens acima. No entanto, segundo revisão realizada por Kardami et al. (2007), a correlação inversa entre 
comunicação intercelular via junções gap e proliferação celular nem sempre se mostra fidedigna em todos os tipos celulares. Por exemplo, a ausência de Cx43 aumentou a proliferação celular em células semelhantes a fibroblastos (MARTYN et al., 1997), enquanto ao mesmo tempo ocasionou redução na proliferação de astrócitos (DERMIETZEL et al., 2000). Nesse sentido, percebe-se que a influência das conexinas na modulação da proliferação celular pode variar de acordo com o contexto, como por exemplo, processos tumorais e nãotumorais. Apesar de exaustivamente estudada em diversas células e tecidos, a correlação da expressão de conexinas e a proliferação celular ainda não está bem estabelecida nas células hepáticas ou nas linhagens celulares derivadas de hepatócitos.

Estudos em camundongos tratados com drogas não-genotóxicas demonstraram redução na expressão de Cx32 no tecido hepático (NEVEU et al., 1995; NAKATA et al., 1996), e conseqüente aumento na proliferação celular (MALLY; CHIPMAN, 2002). Adicionalmente, animais knockout para Cx32 apresentaram maior susceptibilidade ao desenvolvimento do hepatocarcinoma (TEMME et al., 1997), assim como demonstrado em outros estudos relacionados à hepatocarcinogênese (MA et al., 2000, 2002; OMORI et al., 2001; EVERT et al., 2002). Ao contrário do esperado, foi demonstrada menor proliferação dos hepatócitos em camundongos knockout (TEMME et al., 2000) e transgênicos (DAGLI et al., 2004) para Cx32 após hepatectomia parcial. Estes dados indicaram as diferentes influências da comunicação intercelular de acordo com o processo patológico instaurado no tecido hepático.

No entanto, alterações na proliferação celular também foram observadas em relação às outras células presentes no fígado. Camundongos deficientes em $\mathrm{Cx} 43$ infestados por Schistosoma mansoni apresentaram redução na proliferação das células formadoras dos granulomas hepáticos em relação aos animais heterozigotos (OLORIS et al., 2007). Quando estes animais foram submetidos ao modelo de colestase pela ligação do ducto biliar, Teixeira et al. (2007) observaram menor proliferação das células endoteliais e, consequentemente, menor formação de vasos. Estes resultados indicaram que a deficiência da conexina 43 ou o comprometimento das células que normalmente expressam esta proteína, de alguma forma, estão interferindo no processo de hiperplasia celular, seja de hepatócitos ou das células nãoparenquimatosas.

Como mencionado anteriormente, os hepatócitos expressam as conexinas 32 e 26 , enquanto as demais células não-parenquimais expressam, principalmente, Cx43 (VINKEN et al., 2007). No entanto, algumas linhagens celulares derivadas de hepatócitos e cultivadas in vitro realizam sua comunicação intercelular via Cx43, ao invés das Cx32 e Cx26 (NEVEU et 
al., 1995), como por exemplo, a linhagem HTC, oriunda do hepatocarcinoma de rato. Utilizando esta linhagem celular, Ionta et al. (2009) induziram o aumento da expressão de Cx43 nestas células por transfecção de cDNA e observaram redução em sua proliferação. Estudo realizado na linhagem celular $\mathrm{MH}_{1} \mathrm{C}_{1}$, derivada de hepatoma de rato, avaliou a diminuição e aumento na expressão de Cx32 sobre a proliferação celular. Neste trabalho foi demonstrado que houve uma relação inversamente proporcional entre a expressão de Cx32 e a proliferação celular (EDWARDS et al., 2008). Outro estudo demonstrou que fucoxantina, carotenóide presente em algumas frutas e vegetais, possui ação anti-proliferativa em células hepáticas tumorais (linhagem Sk-HEP-1) devido aumento na expressão das conexinas 32 e 43, e conseqüente aumento na comunicação intercelular funcional (LIU et al., 2009). Como demonstrado em diversas células tumorais, a redução da comunicação intercelular também resulta em maior proliferação em células tumorais hepáticas. No entanto, o mesmo não ocorre na regeneração hepática após hepatectomia parcial (TEMME et al., 2000; DAGLI et al., 2004). Os mecanismos pelos quais as conexinas controlam o ciclo celular ainda precisam ser melhores elucidados, principalmente em relação à Cx32.

\subsection{CONEXINAS E APOPTOSE}

O estudo da influência das conexinas no processo apoptótico é relativamente recente. Atualmente sabe-se que as conexinas podem afetar o processo de morte celular por vários mecanismos envolvendo as junções comunicantes do tipo gap, os hemicanais e as conexinas. As junções gap podem contribuir para a troca direta de sinais de morte e sobrevivência entre as células por quatro diferentes mecanismos: pela entrada de sinais de morte ou perda dos sinais de sobrevivência; pela sinalização de mensageiros de morte ou sobrevida; pela transdução de sinais transmembrânicos mediados pelos hemicanais e por afetar a funcionalidade da mitocôndria (Figura 18) (DECROCK et al., 2009). 


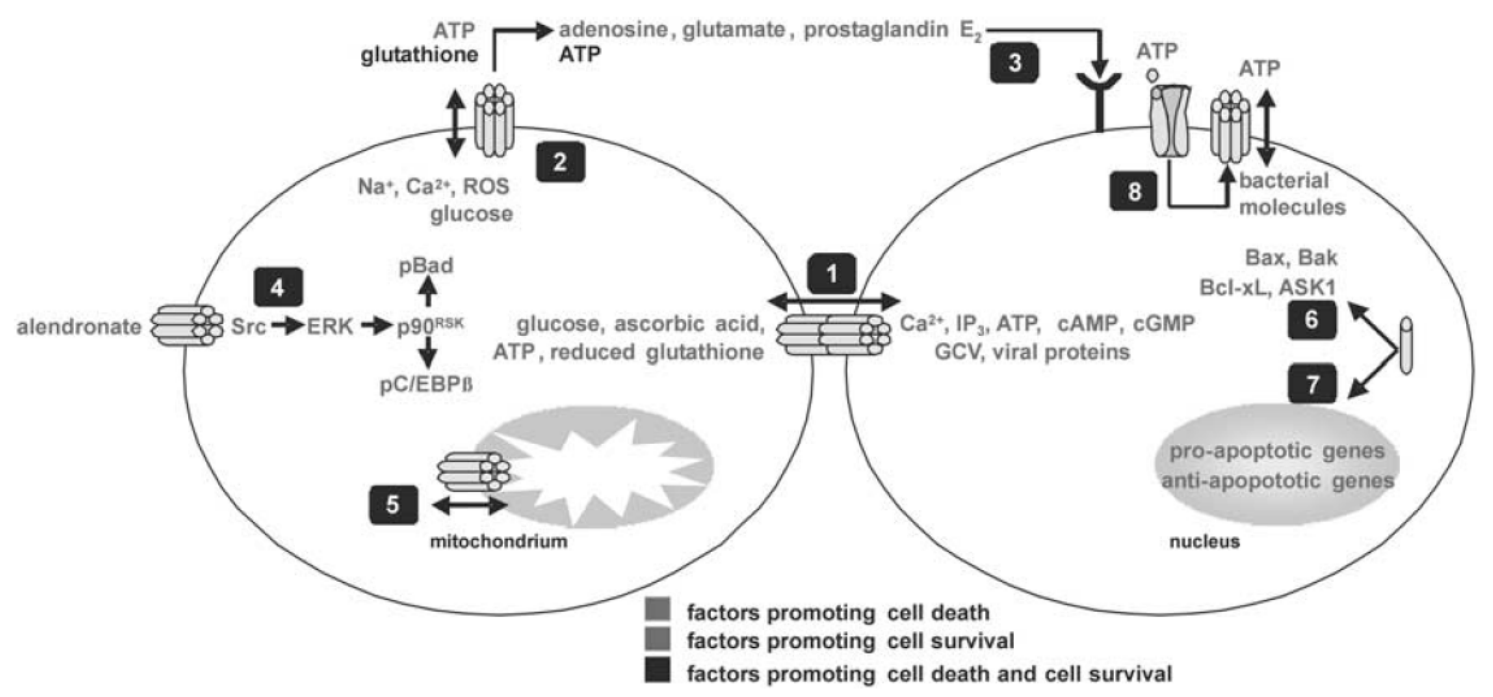

Fonte: (DECROCK et al., 2009)

Figura 18 - Desenho esquemático da sinalização das conexinas no processo de apoptose

Aparentemente, as fases iniciais da apoptose requerem comunicação intercelular pelas junções do tipo gap. Entretanto, com a progressão do processo da morte, a comunicação por estas junções declina drasticamente, acarretando em ausência de ligação entre os corpúsculos apoptóticos. A redução da comunicação pelas gap coincide com as alterações morfológicas que ocorrem durante a apoptose, resultando na remoção das junções gap da membrana plasmática (DECROCK et al., 2009).

Algumas evidências demonstraram a correlação entre as junções comunicantes do tipo gap e o processo apoptótico. Theiss et al. (2007) submeteram células epiteliais do cristalino de bovino e fibroblastos de camundongo a diferentes agentes indutores de apoptose. Os autores notificaram um decréscimo nas junções comunicantes do tipo gap associado à degradação da conexina 43 mediada pela caspase 3. Hwang et al. (2008) incubaram a linhagem F344 de células epiteliais hepáticas de rato com índole-3-carbonol, um fitoquímico encontrado em vegetais crucíferos e, posteriormente, trataram as mesmas culturas com $\mathrm{H}_{2} \mathrm{O}_{2}$, um inibidor da comunicação intercelular pelas junções do tipo gap. O fitoquímico preveniu a ação do $\mathrm{H}_{2} \mathrm{O}_{2}$ sob a comunicação intercelular, evitando a fosforilação da $\mathrm{Cx} 43$ pela inativação da via PKB/Akt. Esta via de sinalização modula a comunicação pelas junções do tipo gap, além de mecanismos que regulam a proliferação, diferenciação e apoptose.

A exposição aguda ao cadmio acarreta em morte celular por apoptose e necrose no fígado. Jeong, Habeebu e Klaassen (2000) estudaram os efeitos apoptóticos e necróticos da 
administração de cadmio no fígado de camundongos. O tratamento reduziu a comunicação pelas junções gap e a expressão das conexinas 26 e 32 no tecido hepático. Os autores relataram que os danos à homeostasia tecidual, provocados pela redução na comunicação intercelular, podem ser responsáveis por desencadear o processo apoptótico.

Tanaka e Grossman (2001) avaliaram a indução de apoptose em diferentes linhagens de tumor de bexiga, onde ocorreu o restabelecimento da expressão da Cx26 e a administração de cisplatina. As linhagens que sofreram o aumento na expressão da Cx26, independente do tratamento com a cisplatina, apresentaram aumento na apoptose devido a redução na expressão de genes pró-apoptóticos da família do Bcl-2. O aumento da expressão da conexina 26 potencializou o efeito da cisplatina, quando os dois tratamentos foram administrados juntos. Em estudo com linhagens de tumor de próstata, o mesmo grupo observou resultados semelhantes após o aumento da expressão da Cx26 e tratamento com doxorubicina (TANAKA; GROSSMAN, 2001).

Kanczuga-Koda et al. (2005) estudaram a relação entre a Cx26 e os genes da família Bcl-2 em pacientes com câncer coloretal e observaram uma relação positiva entre a Cx26 e o pró-apoptóico Bax, bem como entre o anti-apoptótico Bcl-xL. Os autores acreditam que estes resultados sugerem que a Cx26 em células malignas pode estar envolvida no controle do processo apoptótico. Sulkowski et al. (2006) demonstraram que o sistema de crescimento ligado à insulina pode estar envolvido na regulação da apoptose e, provavelmente, na expressão da conexina neste tipo de câncer.

O envolvimento das conexinas no controle da apoptose é observado também em tecidos normais. A redução da expressão da conexina 26 induz apoptose em epitélio mamário de camundongas prenhes (BRY et al., 2004), no epitélio auricular (COHEN-SALMON et al., 2002), em epitélio seminífero de rato (LEE et al., 2006). A hiperexpressão da Cx43 conferiu resistência a diferentes linhagens celulares: aumentou a resistência à apoptose mediada por $\mathrm{H}_{2} \mathrm{O}_{2}$ em linhagem de glioma (GIARDINA et al., 2007); preveniu a apoptose em linhagem de células epitelial humana submetida a estresse oxidativo (HUTNIK et al., 2008) e a perda desta conexina acarretou no aumento da apoptose em astrócitos de camundongo deficiente para a conexina 43 (NAKASE et al., 2004).

A influência das junções gap e/ou das conexinas foram analisadas no tecido hepático e muitos estudos mostraram que a hipo ou hiper expressão ou a sua localização aberrante promovem o aumento da apoptose, entretanto, ainda de maneira pouco elucidada. Ott et al. (2006) estudaram a incidência de apoptose no tecido hepático em camundongos knockout para as conexinas 26 e 32, os quais apresentaram aumento significativo em comparação aos 
animais selvagens (wild-type). Marx-Stoelting et al. (2008) submeteram camundongos knockout para as conexinas 26 e 32 ao carcinógeno hepático N-nitrosodietilamina e observaram significativo aumento de apoptose por $\mathrm{mm}^{2}$ de área de fígado. Entretanto, este resultado apenas foi expressivo nos camundongos knockout para Cx32.

Outras alterações metabólicas que envolvem a indução da apoptose como a deficiência aguda de colina, apresentam alterações nas junções comunicantes do tipo gap e/ou nas conexinas. Albright et al. (2001) estudaram células epiteliais de fígado de rato adaptadas à baixa concentração de colina. Estas células adquirem a capacidade de resistir a apoptose. Os estudos mostraram que esta resistência pode estar relacionada à retenção da conexina 43 no complexo de golgi e redução das junções gap. Ao contrário dos outros estudos, Sai et al. (2001) observaram efeito inverso em linhagem de células epiteliais do fígado de ratos transfectados com v-myc (WB-MYC). As células após tratamento com pentaclorofenol, um promotor de hepatocarcinogênese murina, apresentaram redução nas junções comunicantes do tipo gap e inibição da apoptose. A ocorrência de apoptose no tecido cirrótico tem sido descrita, entretanto, os mecanismos permanecem obscuros (KREMER et al., 2009) e a influência das conexinas na apoptose dos hepatócitos envolvidos no processo cirrótico é pouco conhecida. 


\section{OBJETIVOS}

\subsection{OBJETIVOS GERAIS}

Avaliar os efeitos da deficiência das conexinas 43 ou 32 no desenvolvimento da fibrose hepática, induzida pelo tetracloreto de carbono, em camundongos.

\subsection{OBJETIVOS ESPECÍFICOS}

3.2.1 Avaliar a importância da $\mathrm{Cx} 43$ ou Cx32 no desenvolvimento das lesões necroinflamatórias e na função bioquímica hepática após indução da fibrose.

3.2.2 Avaliar a importância da Cx43 ou Cx32 na proliferação celular e/ou apoptose dos hepatócitos após indução da fibrose.

3.2.3 Avaliar a participação da $\mathrm{Cx} 43$ ou Cx32 no processo de fibrogênese hepática induzido pelo tetracloreto de carbono.

3.2.4 Avaliar os efeitos da deficiência de Cx32 ou Cx43 na expressão gênica das principais proteínas envolvidas nos mecanismos de síntese e degradação da matriz extracelular.

3.2.5 Analisar a expressão gênica e protéica das conexinas na fibrose hepática, assim como a capacidade de comunicação intercelular dos hepatócitos. 


\section{MATERIAIS E MÉTODOS}

\subsection{ANIMAIS GENETICAMENTE MODIFICADOS}

\subsubsection{Camundongos deficientes em $\mathrm{Cx} 43\left(\mathrm{Cx}_{4}{ }^{+/-}\right)$}

Os camundongos heterozigotos em $\mathrm{Cx} 43$ foram originalmente estabelecidos por Reaume et al. (1995) e adquiridos do Laboratório Jackson (Paris) pela International Agency for Research on Cancer (IARC), Lyon, França. Estes animais foram gentilmente doados pelo Dr. Hiroshi Yamasaki ao Departamento de Patologia da Faculdade de Medicina Veterinária e Zootecnia da Universidade de São Paulo (FMVZ-USP), em cujo biotério se encontram atualmente. O background genético original destes camundongos era proveniente da linhagem C57BL/6, a qual foi cruzada com camundongos CD1 para gerar camundongos heterozigotos $\left(\mathrm{Cx} 43^{+/-}\right)$deficientes em um dos alelos do gene da $\mathrm{Cx} 43$, e com background genético da linhagem CD1. Como os camundongos knockout para $\mathrm{Cx} 43\left(\mathrm{Cx} 43^{-/-}\right)$morrem ao nascer devido à mal formação cardíaca (REAUME et al., 1995), neste trabalho foram utilizados os camundongos deficientes em $\left(\mathrm{Cx} 43^{+/-}\right)$e selvagens (wild-type; $\left.\mathrm{Cx} 43^{+/+}\right)$.

Os animais permaneceram em caixas de policarbonato, em sala com fotoperíodo de 12 horas de claro e 12 horas de escuro, sob condições controladas de temperatura de $\left(22 \pm 2^{\circ} \mathrm{C}\right)$ e umidade relativa do ar (45-60\%.). Os animais receberam água (filtrada, $\mathrm{pH} \pm 7.0$ ) e ração (Nuvilab CR1, Nuvital Nutrientes Ltda, Brasil) ad libitum por todo o período experimental.

\subsubsection{Camundongos Knockout para $\mathrm{Cx} 32\left(\mathrm{C}_{3} 32^{-/-}\right)$}

Os camundongos deficientes em Cx32 (+/-) foram obtidos através da técnica de recombinação homóloga (NELLES et al., 1996). Estes foram doados pelo Dr. Klaus Willecke da International Agency for Research on Cancer (IARC), Lyon, França, e posteriormente adquiridos pelo Departamento de Patologia da Faculdade de Medicina Veterinária e Zootecnia da Universidade de São Paulo (FMVZ-USP). Para obtenção dos animais, fêmeas Cx32 
(heterozigoto) foram acasaladas com machos $\mathrm{Cx} 32^{\mathrm{Y} /+}$ (wild-type), obtendo camundongos machos $\mathrm{Cx} 32^{\mathrm{Y} /+}$ (wild-type) e $\mathrm{Cx} 32^{\mathrm{Y} /-}$ (knockout) e fêmeas $\mathrm{C} \times 32^{+/+}$(wild-type) e $\mathrm{Cx} 32^{+/-}$ (heterozigoto), identificados por genotipagem. Para a obtenção de animais knockout para a $\mathrm{Cx} 32\left(\mathrm{C} \times 32^{-/}\right)$, foram acasalados animais $\mathrm{Cx} 32^{+/-} \operatorname{com~} \mathrm{Cx} 32^{\mathrm{Y} /-}$.

Os animais permaneceram em caixas de policarbonato, em sala com fotoperíodo de 12 horas de claro e 12 horas de escuro, sob condições controladas de temperatura $\left(22 \pm 2^{\circ} \mathrm{C}\right)$ e umidade relativa do ar (45-60\%.). Os animais receberam água (filtrada, $\mathrm{pH} \pm 7.0$ ) e ração (Nuvilab CR1, Nuvital Nutrientes Ltda, Brasil) ad libitum por todo o período experimental.

\subsection{CERTIFICADO DE BIOSSEGURANÇA E NORMAS PARA A MANUTENÇÃO E TRABALHOS COM ANIMAIS GENETICAMENTE MODIFICADOS}

O biotério do Departamento de Patologia da FMVZ - USP, bem como o Laboratório de Oncologia Experimental, possuem extensão do certificado de biossegurança da FMVZUSP (CQB no. 100/99), de acordo com as informações da Comissão Interna de Biossegurança (CIBio), com base na instrução normativa da CTNBio $\mathrm{n}^{\circ}$. 12, publicada no Diário Oficial da União $n^{\circ}$. 100-E, de 28 de maio de 1998, Seção 1, páginas 10-12. Os animais estão alojados em sala isolada na área de criação do Biotério da FMVZ - USP, que foi especialmente preparada para recebê-los. Para tanto, foram vedadas todas as possíveis passagens de insetos e de camundongos, encontrando-se os animais em caixas com filtros apropriados. Há cartazes indicativos da presença deles nos locais em que são manipulados.

\subsection{GENOTIPAGEM}

Para a identificação do genótipo dos animais utilizados neste experimento, um fragmento de $0,5 \mathrm{~cm}$ da cauda de cada exemplar foi digerido em tampão de extração (acrescido de proteinase $\mathrm{K}$ ), durante 2 horas em banho-maria à $65^{\circ} \mathrm{C}$ para a extração do DNA. Após a digestão, foi adicionado tampão de lise, homogeneizado e as amostras foram centrifugadas durante 20 minutos $\left(15.000 \mathrm{rpm}\right.$ e a $\left.4^{\circ} \mathrm{C}\right)$. Cerca de $200 \mu \mathrm{L}$ da fase aquosa foi 
transferido para um novo tubo, sendo adicionado $400 \mu \mathrm{L}$ de etanol absoluto e $20 \mu \mathrm{L}$ de acetato de sódio $3 \mathrm{M}(\mathrm{pH}$ 5.2) a fim de precipitar o DNA. Após centrifugação por 10 minutos e $5.000 \mathrm{rpm}\left(4^{\circ} \mathrm{C}\right)$, o DNA foi lavado com etanol $70 \%$ e dissolvido em $200 \mu \mathrm{l}$ de TE (Tris/EDTA). Após a quantificação no biofotômetro, o DNA de cada camundongo foi analisado por PCR com primers para os genes: Cx32 (KO-WT-NEO) 5'CCATAAGTCAGGTGTAAAGGAGG3';

5'ATCATGCGAAACCGATCCTCATCC3' e Cx43 senso 5'CCCCACTCTCACCTATGTCTCC3' e anti-senso 5'ACTTTTGCCGCCTAGCTATCCC3';

NEO senso 5'GGCCACAGTCGATGAATCCAG3' e anti-senso 5'TATCCATCATGGCTGATGCAA3' (YAMAKAGE et al., 1998). A reação da polimerase em cadeia (PCR) para a Cx43 foi realizada durante 1 ciclo, na condição de $94^{\circ} \mathrm{C}$ por 2 minutos, 35 ciclos à $94^{\circ} \mathrm{C}$ por $30 \mathrm{~s}, 55^{\circ} \mathrm{C}$ por 1 minuto, $72^{\circ} \mathrm{C}$ por 4 minutos, 1 ciclo à $72^{\circ} \mathrm{C}$ por 4 minutos e 1 ciclo à $4^{\circ} \mathrm{C}$ por 60 minutos. Para a Cx32, o PCR foi realizado durante 40 ciclos por 15 segundos a $95^{\circ} \mathrm{C}$ e $60^{\circ} \mathrm{C}$ por 1 minuto.

\subsection{PROTOCOLO EXPERIMENTAL}

Camundongos fêmeas, com oito semanas de idade e pesando $22 \pm 4 \mathrm{~g}$, foram submetidos ao modelo de fibrose hepática induzida pelo tetracloreto de carbono $\mathrm{CCl}_{4}$ (Vertec). Os animais deficientes em Cx43 e wild-type ( $\mathrm{n}=10 /$ genótipo) e knockout para Cx32 e wild-type ( $\mathrm{n}=10 /$ genótipo) receberam 3 doses semanais de $\mathrm{CCl}_{4} 10 \%$, diluído em óleo de milho, intraperitonialmente (i.p.), durante 2 meses. Resumidamente, a dose inicial de $\mathrm{CCl}_{4}$ foi $0,25 \mathrm{mg} / \mathrm{kg}$, sendo aumentada 0,25 mg por semana, até a dose final de 1,25 mg/kg (Quadro 5) (modificado de OZDOGAN et al., 2005). Como grupo controle de cada genótipo, o mesmo número de animais recebeu apenas o óleo de milho, i.p. Os camundongos foram anestesiados por overdose anestésica e secção da artéria aorta abdominal ao final do período experimental. Os materiais foram colhidos conforme o item 4.5. 


\begin{tabular}{|cc|}
\hline Semana & Dosagem (mg/kg) \\
\hline $1^{\mathrm{a}}$ & 0,25 \\
\hline $2^{\mathrm{a}}$ & 0,50 \\
\hline $3^{\mathrm{a}}$ & 0,75 \\
\hline $4^{\mathrm{a}}$ & 1,00 \\
\hline $5^{\mathrm{a}}$ a $8^{\mathrm{a}}$ & 1,25 \\
\hline
\end{tabular}

Fonte: (modificado de OZDOGAN et al., 2005)

Quadro 5 - Protocolo experimental de indução do modelo de fibrose hepática pelo tetracloreto de carbono $\left(\mathrm{CCl}_{4}\right)$, i.p., diluído em óleo de milho (10\%), três vezes por semana, durante 2 meses

\subsection{BIOMETRIA E ANÁLISE ANÁTOMOPATOLÓGICA}

Após eutanásia, todos os animais foram pesados (PV) e foram colhidos o fígado, baço, rins, pulmões, coração, intestino e sangue. Após a retirada das vísceras, os animais foram novamente pesados (PC). O fígado de cada animal foi fotografado e examinado macroscopicamente. Foi mensurado o peso do fígado (PF) e calculados os índices

hepatossomático $\left[\mathrm{IHS}=\left(\frac{P V}{P F} * 100\right)\right]$ e hepatocorporal $\left[\mathrm{IHC}=\left(\frac{P C}{P F} * 100\right)\right]$. Posteriormente, fragmentados do fígado foram cortados e fixados em solução de metacarn $(60 \%$ metanol, 30\% clorofórmio e 10\% ácido acético). Após 12 horas de fixação, os fragmentos foram processados e incluídos em parafina. Foram obtidos cortes de $5 \mu \mathrm{m}$ em micrótomo, sendo corados pelas técnicas de hematoxilina-eosina (TILLMANN et al., 1999) para avaliação histopatológica e contagem de corpúsculos apoptóticos sob fluorescência; e picrossírius para a evidenciação e morfometria das fibras colágenas (JUNQUEIRA; BIGNOLAS; BRETANI, 1979). A avaliação histopatológica foi realizada de acordo com os critérios clássicos estabelecidos por Knodell et al. (1981) e modificados por Ishak et al. (1995), onde as lesões foram classificadas segundo sua atividade necro-inflamatória (escores entre 0 e 18) e estadiamento da fibrose (escores entre 1 e 6). Nos quadros 6 e 7 estão descritos os critérios adotados para cada classificação, assim como a pontuação relacionada a cada variável. Para as análises da expressão protéica e gênica, amostras dos tecidos foram colhidas em nitrogênio líquido e armazenadas em freezer $-80^{\circ} \mathrm{C}$. 


\section{Necrose em Saca-Bocados}

Escore

Ausente

0

Suave (focal / poucas regiões portais)

Suave a Moderado (focal / diversas regiões portais)

Moderado (contínuo ao redor de $<50 \%$ das regiões portais ou sinusoidais)

Severo (contínuo ao redor de $>50 \%$ das regiões portais ou sinusoidais)

\section{Necrose}

Escore

Ausente

0

Necrose focal

Necrose em Zona 3 (poucas regiões)

Necrose em Zona 3 (diversas regiões)

Necrose em Zona 3 e ocasionalmente na ponte v. porta - v. terminal hepática

Necrose em Zona 3 e múltiplos locais na ponte v. porta - v. terminal hepática

Necrose multiacinar

Necrose lítica focal / apoptose / inflamação focal*

Ausente

0

1 foco ou menos por campo (objetiva de 10x)

1

2 a 4 focos por campo (objetiva de 10x)

5 a 10 focos por campo (objetiva de 10x)

Mais de 10 focos por campo (objetiva de 10x)

Inflamação portal

Ausente

0

Suave (poucas regiões portais)

Moderado (diversas regiões portais)

Acentuado (todas a regiões portais)

Severo (todas as regiões portais)

Fonte: (modificado de ISHAK et al., 1995)

Quadro 6 - Critérios histopatológicos para graduação de hepatites crônicas. *Não inclui infiltrado inflamatório sinusoidal difuso 


\begin{tabular}{|c|c|}
\hline Alterações estruturais / Fibrose / Cirrose & Escore \\
\hline Sem fibrose & 0 \\
\hline $\begin{array}{l}\text { Expansão da fibrose em algumas regiões portais, com ou sem pequenos septos } \\
\text { fibrosos }\end{array}$ & 1 \\
\hline $\begin{array}{l}\text { Expansão da fibrose em diversas regiões portais, com ou sem pequenos septos } \\
\text { fibrosos }\end{array}$ & 2 \\
\hline $\begin{array}{l}\text { Expansão da fibrose em diversas regiões portais, com ocasional formação de pontes } \\
\text { entre os espaços portais }\end{array}$ & 3 \\
\hline $\begin{array}{l}\text { Expansão da fibrose nas regiões portais, com marcante formação de pontes entre os } \\
\text { espaços portais ou entre a v. porta e v. terminal hepática }\end{array}$ & 4 \\
\hline $\begin{array}{l}\text { Marcante formação de pontes entre os espaços portais e entre a v. porta e v. terminal } \\
\text { hepática, com formação ocasional de nódulos (cirrose incompleta) }\end{array}$ & 5 \\
\hline Cirrose & 6 \\
\hline
\end{tabular}

Fonte: (modificado de ISHAK et al., 1995)

Quadro 7 - Critérios histopatológicos para estadiamento da fibrose nas hepatites crônicas

\subsection{QUANTIFICAÇÃO DO COLÁGENO}

Para avaliação do processo fibrogênico hepático, a quantificação do colágeno depositado nos espaços perivasculares foi realizada em cortes histológicos corados apenas com picrossírius (JUNQUEIRA et al., 1979) e analisados sob microscopia de luz (Nikon E800). As áreas das fibras colágenas coradas foram quantificadas automaticamente em sistema de análise de imagens computadorizado (Image Pro-Plus 4.5). Os resultados foram expressos em porcentagem de área ocupada pelo colágeno em relação ao campo total. Esta porcentagem é equivalente à proporção volumétrica de colágeno presente no fígado (WEIBEL, 1989). 


\subsection{MICROSCOPIA ELETRÔNICA DE TRANSMISSÃO}

Fragmentos de fígado dos animais deficientes em Cx43 foram fixados em solução de glutaraldeído $2,5 \%$, preparado em tampão fosfato $0.1 \mathrm{M}$ (pH 7.4). Depois, as amostras foram pós-fixadas em tetróxido de ósmio $\left(\mathrm{OsO}_{4}\right)$ 2\% durante 2 horas e contrastadas em solução saturada de acetato de uranila. Seguiu-se com a desidratação alcoólica gradual e lavagem com óxido de propileno para posterior inclusão em resina araldite. Foram obtidos cortes semi-finos corados com azul de toluidina para identificação das regiões de interesse. Depois, foram realizados os cortes ultra-finos na telas adequadas para a visualização no microscópio eletrônico de transmissão JEOL.

\subsection{MICROSCOPIA ELETRÔNICA DE VARREDURA}

Fragmentos do fígado foram fixados em solução de Karnowisky modificada, utilizando fragmentos intactos para avaliação da superfície hepática. Todas as amostras foram lavadas em PBS e impregnadas com ácido tânico 1\% durante 2 horas. Após, procedeu-se a fixação em tetróxido de ósmio $1 \%$, desidratação em série crescente de álcool etílico, ponto crítico, montagem em stubs e metalização com ouro. Todas as observações e fotografias foram realizadas em microscópio eletrônico de varredura (LEO, 435VP, 20kV).

\subsection{ANÁLISE BIOQUÍMICA DA FUNÇÃO HEPÁTICA}

O sangue dos animais foi colhido por punção cardíaca ou através da veia cava caudal, para avaliação da função bioquímica hepática. $\mathrm{O}$ material foi centrifugado durante $10 \mathrm{~min}$, $4.000 \mathrm{rpm}$ e a $4^{\circ} \mathrm{C}$ para separação do soro, o qual foi armazenado em freezer $-80^{\circ} \mathrm{C}$ até o momento da análise. Foram dosados os seguintes parâmetros bioquímicos: aspartato aminotranferase (AST, U/l), alanina aminotransferase (ALT, U/1), gama-glutamiltranferase (GGT, U/l), fosfatase alcalina (FA, U/l), proteínas total (g/dl), albumina (g/dl) e bilirrubina 
total (mg/dl). Os slides com cada teste foram processados e analisados no equipamento Vet Test 8008 (QBC Analyzer, IDEXX Laboratories Ltd, Chalfont St Peter, UK).

\subsection{IMUNOFLUORESCÊNCIA PARA CONEXINAS E COLÁGENO TIPO I}

Lâminas histológicas dos tecidos obtidos dos camundongos deficientes em $\mathrm{Cx} 43$ ou Cx32 foram submetidas aos procedimentos convencionais de desparafinização e diafanização. Cortes de $5 \mu \mathrm{m}$ foram desmascarados em solução de Tris-EDTA (pH 9,0), durante 20 minutos em microondas. Para a imunomarcação do colágeno tipo I, os cortes foram submetidos à digestão enzimática com pepsina $0,4 \%$ (Sigma), diluída em ácido acético $0.5 \mathrm{~N}$, durante 30 minutos e em estufa à $37^{\circ} \mathrm{C}$. Após, os cortes foram submetidos ao bloqueio da peroxidase em solução de $\mathrm{H}_{2} \mathrm{O}_{2} 5 \%$, diluído em metanol, durante 30 minutos. Após lavagens, o bloqueio antigênico das lâminas foi realizado em TNB, durante 15 minutos. Em seguida, os cortes foram lavados e incubados em câmera úmida, overnight e a $4^{\circ} \mathrm{C}$, com anticorpos policlonais anti-Cx32, Cx43, Cx26 (Zymed Laboratories, San Francisco, CA 94080, 1:500) ou anticolágeno tipo I (Rockland, USA, 1:50). Posteriormente, as lâminas foram incubadas com anticorpo secundário biotinilado (Dako, Carpinteria, CA, USA, 1:500) durante 30 minutos, em câmera úmida. Seguiu-se a conjugação com o complexo estreptavidina (1:100) durante 30 minutos, sendo amplificada pelo sistema TSA (Tyramide Signal Amplification, New Life Science Products, Boston, MA, EUA). Por fim, as lâminas foram incubadas com Iodeto de Propídeo (1:1000) para possibilitar a visualização nuclear. As lâminas foram montadas com Vectashield para evitar o esgotamento da fluorescência (Vector Laboratories, Inc, Burlingame, CA, USA) e vedadas com esmalte.

\subsection{IMUNO-HISTOQUÍMICA PARA PCNA}

Foram realizadas reações de imuno-histoquímica para a detecção de hepatócitos em proliferação pelo antígeno nuclear de proliferação celular (PCNA). Os cortes histológicos foram desmascarados em tampão de ácido bórico 0,2 $\mathrm{M}(\mathrm{pH} 7,2)$, durante 12 minutos em microondas. Após, os cortes foram submetidos ao bloqueio da peroxidase em solução de $\mathrm{H}_{2} \mathrm{O}_{2}$ 
5\%, diluído em metanol, durante 30 minutos. Após lavagens, o bloqueio antigênico das lâminas foi realizado em solução de leite desnatado a $5 \%$, durante 15 minutos e à $37^{\circ} \mathrm{C}$. Em seguida, os cortes foram lavados e incubados em câmera úmida, overnight e a $4^{\circ} \mathrm{C}$, com anticorpo monoclonal anti-PCNA (Dako, 1:100). Posteriormente, as lâminas foram incubadas com anticorpo secundário biotinilado universal, durante 30 minutos, seguidas da incubação com o complexo estreptavidina-peroxidase kit LSAB+System-HRP (Dako, Carpinteria, CA, USA), durante 30 minutos. As células positivas foram evidenciadas após a coloração com diaminobenzidina (DAB + Chromogen, Dako Carpinteria, CA, USA). As lâminas com cortes de intestino foram utilizadas como controle positivo da reação de imuno-histoquímica para verificação dos anticorpos testados. Também foram realizados controles negativos de todas as reações, utilizando IgG correspondentes ao anticorpo testado. Foi mensurado a quantidade de hepatócitos positivos para PCNA por $\mathrm{mm}^{2}$ de tecido hepático.

\subsection{AVALIAÇÃO FUNCIONAL DA COMUNICAÇÃO INTERCELULAR PELA TÉCNICA DE TRANSFERÊNCIA DE LUCIFER YELLOW (CUT-END) IN SITU}

Esta técnica consiste na aplicação de uma mistura de corantes florescentes com propriedades de difusão opostas sobre uma incisão no tecido hepático. Um dos corantes utilizados foi o lucifer yellow, que devido ao seu baixo peso molecular $(<1-2 \mathrm{kDa})$ se difunde passivamente no tecido através das junções do tipo gap. $\mathrm{O}$ outro corante, a rodamina, que possui um peso molecular superior a $10 \mathrm{kDa}$, não passa pelas junções, permanecendo apenas nas células lesadas pela incisão, servindo como um marcador da lesão realizada. Assim, após a eutanásia dos animais deficientes em conexina 32, foi colhido rapidamente um fragmento do fígado destes animais, onde foram realizadas quatro incisões $(7-8 \mathrm{~mm})$ sobre sua superfície. Imediatamente após as incisões, uma solução de corantes $(0,5 \%$ lucifer yellow e 0,5\% rodamina dextran) foi gotejada sobre os cortes e os fragmentos de tecido foram incubados durante 5 minutos. Depois, as amostras foram lavadas em solução salina, fixadas em formol tamponado $(3,7 \%)$ overnight, e posteriormente incluídas em parafina. Os cortes histológicos foram desparanifizados e analisados em microscopia de fluorescência (Nikon E-800). Foram mensurados a área de difusão do corante lucifer yellow no tecido hepático, assim como o comprimento do corte realizado no tecido. Assim, foi possível estabelecer a distância percorrida pelo corante através das junções do tipo gap. 


\subsection{EXTRAÇÃO DE PROTEÍNAS E QUANTIFICAÇÃO}

Para a estimação das conexinas no fígado de camundongos deficientes em Cx43 ou Cx32, foi realizada a extração e quantificação de proteínas para posterior realização da técnica de western blot. Assim, a proteína total foi extraída de, aproximadamente, $40 \mathrm{mg}$ de tecido hepático congelado. Sob refrigeração, as amostras foram incubadas em $400 \mu 1$ de solução de 2x sample buffer (SDS 4\%; Tris- $\mathrm{HCl} 120 \mathrm{mM} \mathrm{pH=6,8;} \mathrm{Glicerol} \mathrm{20 \% ;} \mathrm{H}_{2} \mathrm{O}$ destilada autoclavada) e trituradas com macerador de tecido durante 6 segundos. Depois, foi adicionado igual volume da solução working solution (2x Sample Buffer; DTT 100 mM; PMSF 1 mM; $\mathrm{H}_{2} \mathrm{O}$ destilada autoclavada) e as amostras foram centrifugadas a $13000 \mathrm{rpm}$, durante $15 \mathrm{~min}$ e $4^{\circ} \mathrm{C}$. O sobrenadante foi recolhido e a concentração de proteínas foi determinada em biofotômetro (Eppendorf, Hamburg, Germany).

\subsection{WESTERN BLOT}

Para a quantificação das conexinas no fígado de camundongos deficientes em Cx43 ou $\mathrm{Cx} 32$, as proteínas totais extraídas do tecido foram submetidas à corrida eletroforética em gel de poliacrilamida (12\% em SDS). Após, as proteínas foram transferidas durante 7 minutos (IBlot, Invitrogen) para membranas de difluoreto de polivinilideno (PDVF) ou nitrocelulose. O bloqueio de reações inespecíficas nas membranas foi realizado com solução de skin milk 5\%, diluído em TTBS, durante 2 horas em temperatura ambiente e sob leve agitação. Para a marcação das conexinas, foi utilizado anticorpo policlonal anti-Cx32, Cx26 e Cx43 (Zymed, 1:200 em TTBS contendo $5 \%$ de skin milk). As membranas foram incubadas à $4^{\circ} \mathrm{C}$, overnight, sob leve agitação. Após lavagens, as membranas foram incubadas com anticorpos secundários de cabra anti-coelho, conjugados com peroxidase (SantaCruz, 1:1000 em TTBS contendo 5\% de skin milk). A ligação foi revelada com uma solução contendo diaminobenzidina (Sigma), sulfato de níquel e peróxido de hidrogênio. A membrana foi escaneada e incubada novamente com o anticorpo monoclonal anti- $\beta$-actina (Sigma, 1:500 em TTBS contendo 5\% de skin milk), utilizada como controle endógeno tecidual para garantir que todas as amostras corridas no gel de poliacrilamida possuiam a mesma quantidade inicial de proteína. 


\subsection{EXTRAÇÃO DE RNA}

Extração de RNA do tecido hepático foi realizada com o kit para extração de RNA RNAspin Mini RNA Isolation Kit (GE). Cerca de $30 \mathrm{mg}$ de tecido hepático foi adicionado em $350 \mu \mathrm{L}$ da solução de lise RA1 do kit, acrescido de 3,5 $\mu \mathrm{L}$ de ß-mercaptoetanol, sendo macerado com a ajuda de um pistilo autoclavado e RNAse-free. A partir deste momento a mistura foi transferida para colunas de extração, seguindo o protocolo determinado pelo fabricante do kit de extração. O processo consistiu basicamente em colocar as células em pequenas colunas de extração (adaptáveis a um eppendorff de 1,5 mL), estas reteram o RNA enquanto o mesmo foi lavado e purificado com uma seqüência de reagentes. Na etapa final o reagente promoveu a liberação do RNA da coluna, o qual foi mantido em freezer $-80^{\circ} \mathrm{C}$ até o momento do uso.

\subsection{QUANTIFICAÇÃO E DETERMINAÇÃO DA INTEGRIDADE DO RNA TOTAL}

Uma alíquota de $10 \mu \mathrm{L}$ foi retirada para quantificação e verificação da integridade do RNA. O restante foi armazenado imediatamente em freezer $-80^{\circ} \mathrm{C}$ até sua utilização. A análise qualitativa foi realizada submetendo-se as amostras a eletroforese em gel de agarose 1,5\% diluída em TAE $1 \mathrm{X}$ (48,4g de Tris base; 20mL de EDTA 0,5M, pH 8,0; 1L,4mL de Ácido Acético; $\mathrm{H}_{2} \mathrm{O}$ MilliQ autoclavada q.s.p. $1000 \mathrm{~mL}$ ), 60V, por 1,5 hora. Após a eletroforese, o gel foi corado em solução de brometo de etídio $\left(0,5 \mathrm{mg} / \mathrm{mL}\right.$ em $\mathrm{H}_{2} \mathrm{O}$ destilada) para a visualização das bandas $28 \mathrm{~S}$ e $18 \mathrm{~S}$ em luz UV. A correta identificação destas bandas indica a qualidade do RNA. A quantificação foi realizada em biofotômetro (Eppendorf, Hamburg, Germany) a 260/280 nm. Amostras num range de 1,7 até 2,0 $\mathrm{ng} / \mu \mathrm{L}$ indicaram baixa contaminação do RNA, sendo consideradas de boa qualidade para a transcrição reversa. 


\subsection{TRANSCRIÇÃO REVERSA}

Para eliminar quaisquer resquícios de DNA, o RNA total foi tratado com DNAse I. Foi utilizados $1 \mu \mathrm{l}$ de DNAse I para tratar $4 \mu \mathrm{g} / \mu \mathrm{l}$ de RNAtotal. Os eppendorfs foram mantidos a temperatura ambiente por 15 minutos, sendo adicionado $1 \mu 1$ de EDTA $(25 \mathrm{mM})$ para bloquear a ação da enzima e aquecidos por 10 minutos a $65^{\circ} \mathrm{C}$ em banho seco seguido de resfriamento em banho de gelo. As amostras receberam $1 \mu \mathrm{L}$ de Oligo DT; $1 \mu \mathrm{L}$ de dNTPs (mix 10mM$2,5 \mathrm{mM}$ de cada $\mathrm{dNTP}$ ) e posteriormente foram incubadas a $65^{\circ} \mathrm{C}$ por 5 minutos e resfriadas em gelo. Ainda no gelo foram adicionados a cada tudo $4 \mu \mathrm{L}$ do buffer $5 \mathrm{X}$ (superscript II); 2 $\mu 1$ de DTT $1 \mathrm{M} ; 1 \mu \mathrm{L}$ de RNAse OUT incubando-se por 2 minutos a $42^{\circ} \mathrm{C}$ e resfriadas no gelo. Foi acrescido $1 \mu \mathrm{Lda}$ enzima de transcrição reversa superscript II, permanecendo em incubação a $42^{\circ} \mathrm{C}$, por 50 minutos e em seguida por $70^{\circ} \mathrm{C}$ por 15 minutos e resfriados no gelo. Em seguida foi acrescido $1 \mu \mathrm{L}$ da enzima RNAse $H$ (para eliminação de resíduos de RNA da amostra de cDNA), permanecendo por 20 minutos a $37^{\circ} \mathrm{C}$. O cDNA foi armazenado a $-20^{\circ} \mathrm{C}$ até o momento da amplificação do cDNA. Todos os reagentes foram fornecidos pela Invitrogen Life Technologies.

\subsection{QUANTIFICAÇÃO DA EXPRESSÃO GÊNICA POR PCR EM TEMPO REAL}

A análise por PCR em tempo real foi realizada em sistema de detecção ABI PrismÒ 7000 (Applied Biosystems, Foster City, CA) o qual contém uma câmera CCD acoplada que captura a fluorescência emitida e analisa os dados utilizando um programa de detecção. Para avaliação da expressão foram colocados em tubos apropriados (Optical Tubes Applied Biosystems) $5 \mu \mathrm{L}$ de cada produto de PCR (cerca de 10ng de RNA total), tampão A TaqMan $1 \mathrm{X}, \mathrm{MgCl}_{2}$ 5,5 mM, $200 \mathrm{nM}$ de dATP/dCTP/dGTP, 400vM dUTP, $200 \mathrm{nM}$ dos primers (senso e antisenso), $100 \mathrm{nM}$ das probes TaqMan, 0,01U/mL de AmpErase e $0.025 \mathrm{U} / \mu 1 \mathrm{da}$ DNA polimerase AmpliTaq Gold em um volume total de $50 \mu \mathrm{L}$. Após s completa mistura dos reagentes cada tubo foi fechado com tampas MicroAmp Optical (Applied Biosystems). Todas as reações foram corridas em duplicata. As condições de amplificação utilizadas para quase todos os genes foram: 2 minutos a $50^{\circ} \mathrm{C}, 10$ minutos à $95^{\circ} \mathrm{C}$; seguidos de 50 ciclos a $90^{\circ} \mathrm{C}$ por 
15 segundos para desnaturação da fita de cDNA e a $60^{\circ} \mathrm{C}$ por 1 minuto para sua extensão. Para análise da MMP-13, foram utilizados os seguintes parêmetros: 2 minutos a $50^{\circ} \mathrm{C}, 10$ minutos à $95^{\circ} \mathrm{C}$; seguidos de 50 ciclos a $90^{\circ} \mathrm{C}$ por 15 segundos. A interpretação dos resultados foi realizada conforme descrito pelo método comparativo de Livak e Schmittgen (2001) onde a expressão relativa dos genes corresponde a $2^{-\Delta \Delta \mathrm{Ct}}$.

\subsection{ASSAYS (PRIMERS)}

Todos os assays (primers) foram adquiridos da empresa Applied Biosystems, e seus respectivos IDs estão descritos no quadro 8.

\begin{tabular}{|c|c|}
\hline GENES & ASSAY ID \\
\hline Cx32 & Mm01700207_m1 \\
\hline Cx26 & Mm00433643_s1 \\
\hline Cx43 & Mm00439105_m1 \\
\hline TGFß-1 & Mm00441724_m1 \\
\hline MMP-2 & Mm00439508_m1 \\
\hline MMP-13 & Mm00439491_m1 \\
\hline uPa & Mm00447054_m1 \\
\hline TIMP-1 & Mm00441818_m1 \\
\hline Colágeno tipo I & Mm00801666_g1 \\
\hline$\alpha$-Actina do Músculo Liso & Mm00725412_s1 \\
\hline 18S (Controle endógeno) & $4352930 \mathrm{E}$ \\
\hline
\end{tabular}

Quadro 8 - Assays da empresa Applied Biosystems utilizados para análise da expressão gênica por PCR em tempo real 


\subsection{ANÁLISE ESTATÍSTICA}

Todos os dados foram expressos em valores de média e desvio padrão. Para a comparação das médias dos parâmetros quantificados foi utilizada a análise de variância seguida da aplicação do teste $t$-Student, adotando nível de significância de $5 \%(p<0,05)$. Para a análise de médias relativas (\%) foi utilizado o teste ANOVA, com $p<0,05$ (Prisma 3.0). 


\section{Animais Deficientes}

\section{em Cx43}

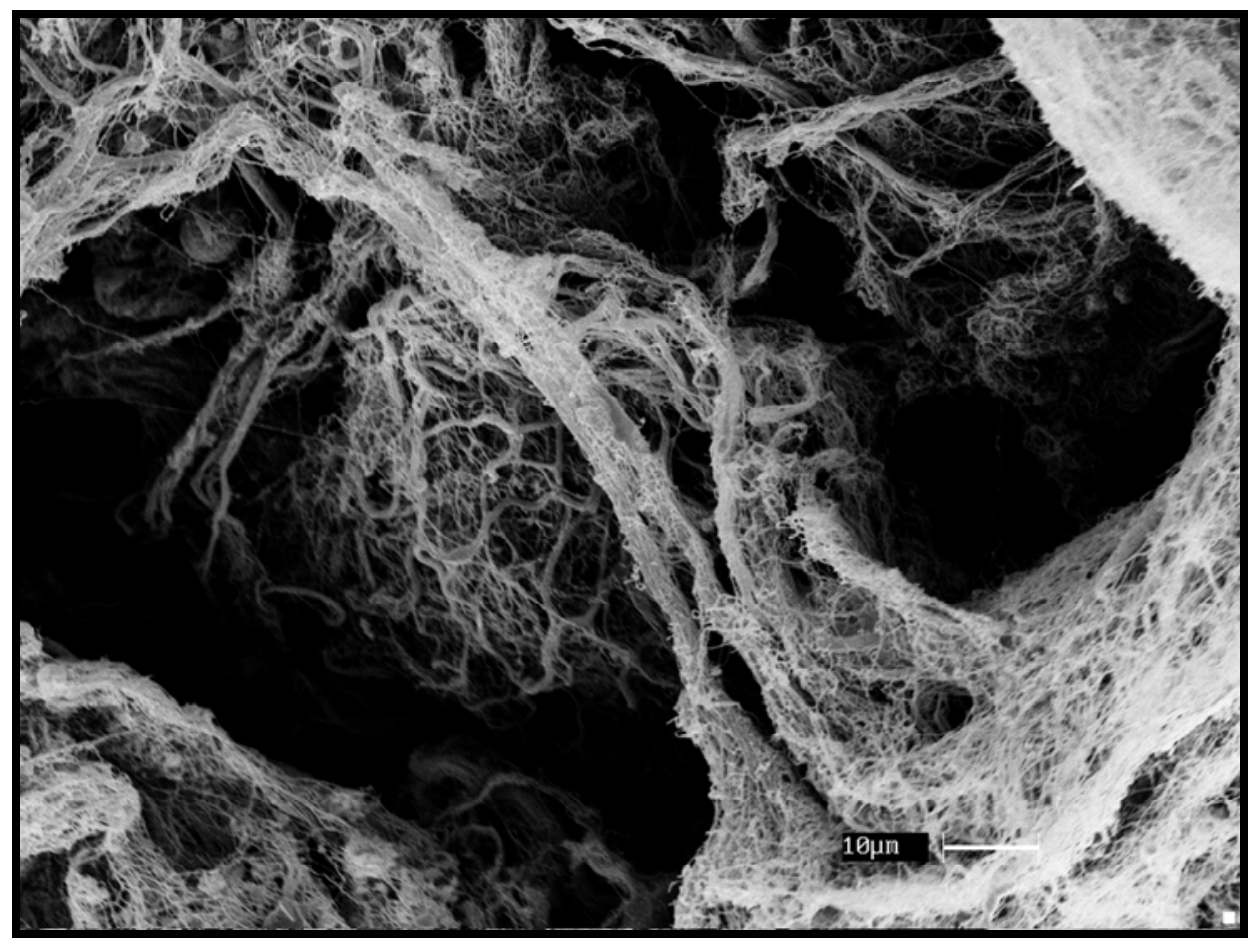




\section{$5 \quad$ RESULTADOS}

\subsection{DEFICIÊNCIA DE Cx43 AUMENTA FIBROSE HEPÁTICA}

Inicialmente foram analisados os parâmetros biométricos que compararam o peso do fígado (PF) e os índices hepáticos relacionados ao peso vivo (IHS) e corpóreo (IHC) dos animais submetidos ao modelo de fibrose hepática. Os dados obtidos demonstraram que não houve diferença estatística entre os animais deficientes em $\mathrm{Cx} 43\left(\mathrm{Cx} 43^{+/-}\right)$e os animais wildtype (WT) em todos os parâmetros biométricos analisados (Figura 19).

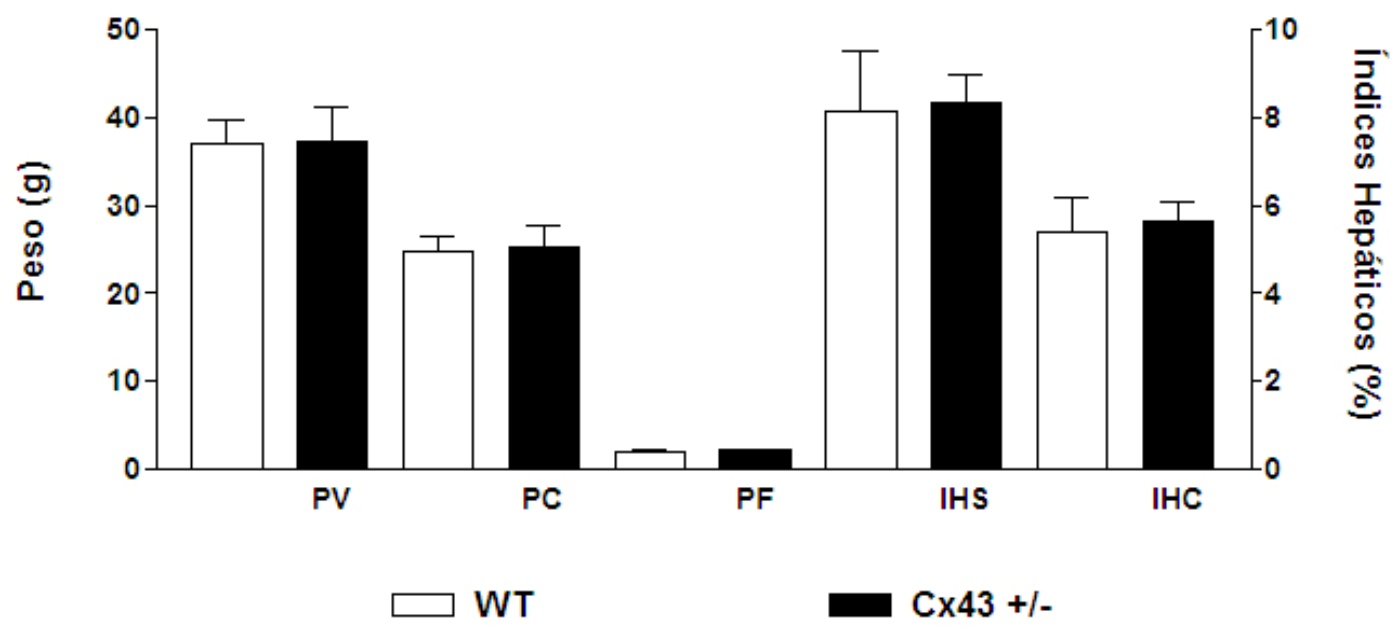

Figura 19 - Principais parâmetros biométricos obtidos após a eutanásia dos camundongos wild-type (WT) e deficientes em $\mathrm{Cx} 43\left(\mathrm{Cx} 43^{+/-}\right)$submetidos ao modelo de fibrose hepática pelo $\mathrm{CCl}_{4}(\mathrm{n}=10$ /genótipo). Não houve diferença estatística em nenhum dos parâmetros. PV: Peso Vivo; PC: Peso Corporal; PF: Peso do Fígado; IHS: Índice Hepatossomático; IHC: Índice Hepatocorporal

No entanto, na análise macroscópica observou-se que o fígado dos animais $\mathrm{Cx} 43^{+/}$ fibróticos apresentaram um processo de micronodulação superficial mais acentuado, com comprometimento dos bordos e retração da cápsula hepática mais grave (Figura 20A e B). Estes resultados também foram observados na microscopia eletrônica de varredura (Figura 20C-E), evidenciando uma maior nodulação na superfície hepática nos animais $\mathrm{Cx} 43^{+/-} \mathrm{em}$ relação aos animais WT (Figura 20E). 

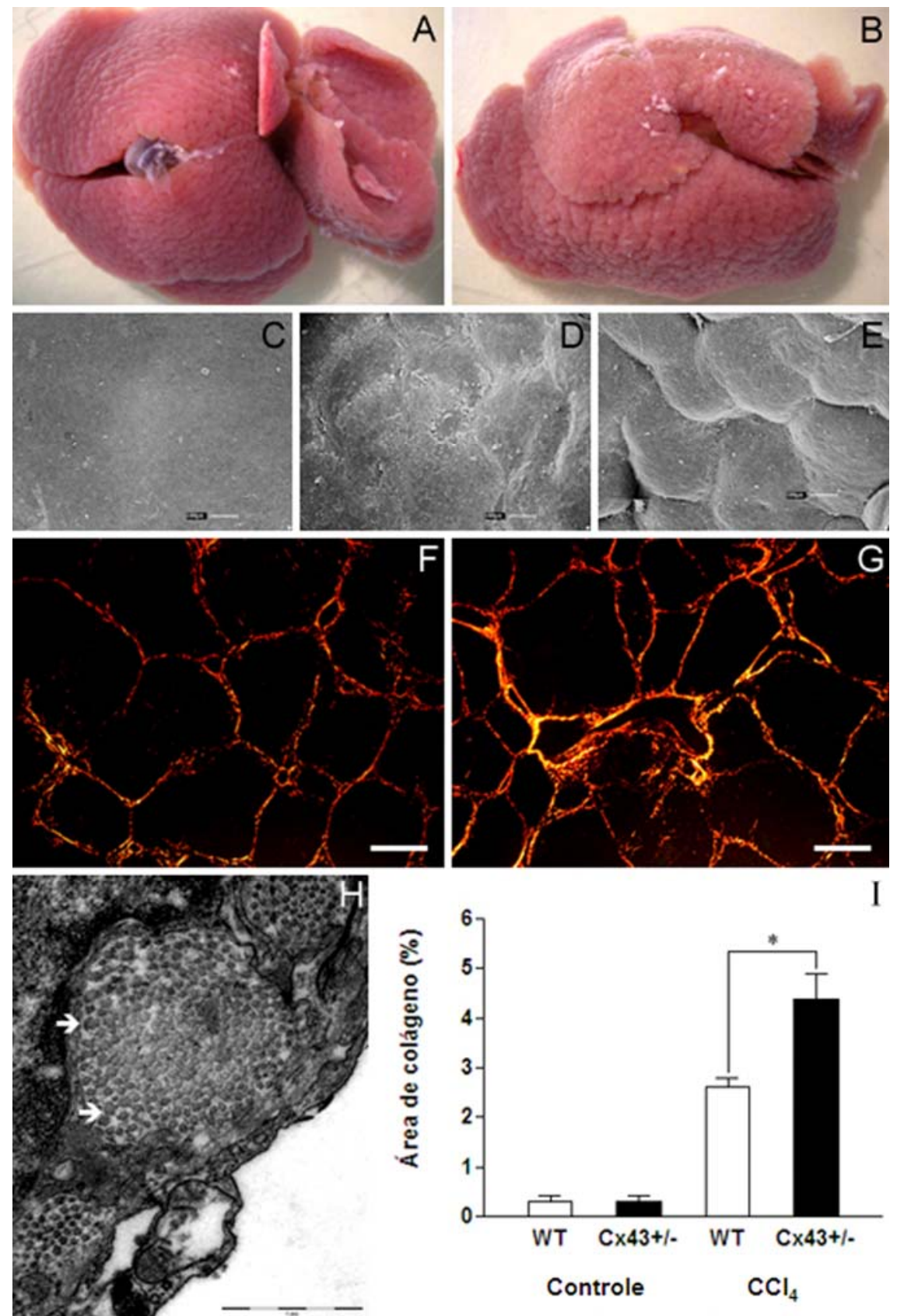

Figura 20 - Análise da fibrose hepática nos animais deficientes em $\mathrm{Cx} 43$. Os animais $\mathrm{Cx} 43^{+/-}$ apresentaram intensificação no processo de micronodulação da superfície hepática, com comprometimento dos bordos e retração da cápsula hepática. (A) Animal WT fibrótico. (B) Animal $\mathrm{Cx} 43^{+/-}$fibrótico. Microscopia eletrônica de varredura da superfície hepática. (C) Animal controle. (D) Animal WT fibrótico. (E) Animal $\mathrm{Cx}_{43}{ }^{+/-}$fibrótico. Barra de escala $=100 \mu \mathrm{m}$. Os animais deficientes em $\mathrm{Cx} 43$ apresentaram maior deposição de colágeno no fígado, com maior densidade dos feixes fibrosos. (F) Animal WT fibrótico. (G) Animal $\mathrm{Cx} 43^{+/-}$fibrótico. Barra de escala $=50 \mu \mathrm{m} .(\mathrm{H})$ Análise ultra-estrutural do fígado fibrótico de animais $\mathrm{Cx} 43^{+/-}$ mostrou fibrilas colágenas espessadas e com morfologia irregular (setas). Barra de escala $=1 \mu \mathrm{m}$. (I) Gráfico demonstrando que os animais $\mathrm{Cx} 43^{+/-}$apresentaram aumento na área ocupada pelo colágeno no parênquima hepático. $(*)$ diferença estatística significante $(p=0,000)$ 
A análise histológica comparativa das lâminas coradas pela técnica de picrossírius, segundo os critérios modificados por Ishak et al. (1995), não demonstraram diferença significativa no estadiamento do grau da fibrose hepática entre os genótipos. No entanto, apesar de não haver diferença no grau da fibrose segundo este critério, identificou-se um aumento visual na proporção volumétrica ocupada pelo colágeno no tecido hepático dos animais deficientes em $\mathrm{Cx} 43$. Sendo assim, quando as fibras colágenas identificadas por esta coloração foram quantificadas automaticamente em programa de análise de imagens, pode-se comprovar que a fibrose hepática foi mais intensa nos animais $\mathrm{Cx} 43^{+/-}$(Figura 20F e G). A morfometria demonstrou aumento de $66,8 \%$ na área ocupada pelo colágeno no parênquima hepático dos animais $\mathrm{Cx} 43^{+/-}$em comparação com os animais WT fibróticos (Figura 20I). A intensificação da fibrose hepática também foi observada após a imunomarcação das fibras colágenas tipo I (Figura 21B), corroborando os dados da morfometria pelo picrossírius.

$\mathrm{Na}$ microscopia eletrônica de transmissão, foi observada grande quantidade de fibrilas colágenas depositadas ao redor de células não-parenquimatosas e nos espaços perissinusoidais em ambos os genótipos. Em corte transversal, os animais $\mathrm{Cx} 43^{+/-}$fibróticos apresentaram fibrilas colágenas espessadas e com morfologia irregular (Figura 20H). Estas alterações não foram observadas nos animais WT com fibrose hepática.
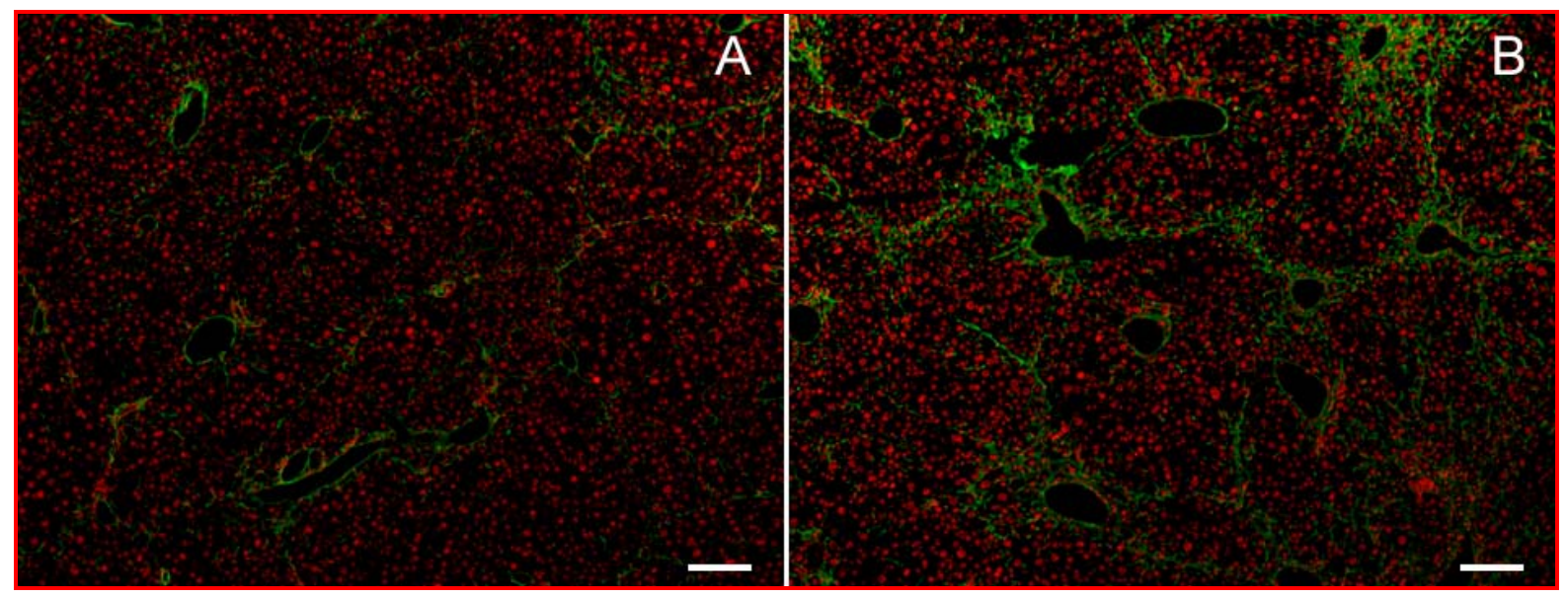

Figura 21 - Imunofluorescência para colágeno tipo I. A) Animal WT; B) Animal Cx43 ${ }^{+/-}$. Os animais deficientes em conexina 43 apresentaram maior quantidade de colágeno tipo I, corroborando os dados da morfometria do picrossírius $(n=10 /$ genótipo $)$. Barra de escala $=50 \mu \mathrm{m}$ 


\subsection{DEFICIÊNCIA DE CX43 ATENUA A INJÚRIA HEPATOCELULAR}

As alterações morfológicas causadas pelo $\mathrm{CCl}_{4}$ nos animais de ambos os genótipos (Figura 22A e C) foram visualizadas nas lâminas coradas por hematoxilina-eosina e avaliadas segundo a classificação de Ishak et al. (1995). Os animais $\mathrm{Cx} 43^{+/-}$apresentaram redução de $23 \%$ na atividade necro-inflamatória, indicando menor intensidade e freqüência das lesões hepáticas (Figura 22A-C). As amostras do soro dos animais, obtidas após a centrifugação das amostras sanguíneas colhidas no momento da eutanásia, foram submetidas a diversas dosagens bioquímicas relacionadas aos parâmetros indicadores da função hepática. Os animais fibróticos $\mathrm{Cx} 43^{+/-}$apresentaram redução de $26 \%$ na concentração sérica de AST e redução de 31\% na concentração sérica de ALT em relação aos animais fibróticos WT. Os valores séricos dos animais fibróticos também foram superiores aos dos animais controles. Os demais parâmetros bioquímicos, como albumina, proteína total, fosfatase alcalina e bilirrubina total não apresentaram diferença entre os genótipos (Tabela 2). A proliferação dos hepatócitos foi quantificada pela contagem de células PCNA-positivas por $\mathrm{mm}^{2}$ de tecido hepático. Os resultados demonstraram menor proliferação celular dos hepatócitos nos animais fibróticos $\mathrm{Cx} 43^{+/-}$, com redução de $71,8 \%$ em relação aos animais WT (Figura 22D).

Tabela 2 - Parâmetros da função bioquímica hepática em animais controles e animais deficientes em Cx43 e WT fibróticos (n = 10/genótipo) - São Paulo - 2008.

\begin{tabular}{ccccc}
\hline Parâmetros & $\begin{array}{c}\text { Animais } \\
\text { Controles }\end{array}$ & $\begin{array}{c}\text { Animais WT } \\
\text { Fibróticos }\end{array}$ & $\begin{array}{c}\text { Animais Cx43 } \\
\text { Fibróticos }\end{array}$ & p-value \\
\hline FA (U/L) & $102,8 \pm 7,9$ & $118 \pm 47,3$ & $109,5 \pm 22,3$ & 0,703 \\
AST (U/L) & $92,3 \pm 6,4$ & $174,8 \pm 10,9$ & $129,5 \pm 10,6$ & $0,000^{*}$ \\
ALT (U/L) & $48,3 \pm 4,5$ & $101,6 \pm 24,7$ & $69,8 \pm 14,4$ & $0,026^{*}$ \\
Albumina (g/dl) & $1,1 \pm 0,3$ & $1,4 \pm 0,2$ & $1,4 \pm 0,2$ & 0,724 \\
Proteína total (g/dl) & $5,1 \pm 0,2$ & $5 \pm 0,3$ & $5,1 \pm 0,1$ & 0,406 \\
Bilirrubina total (mg/dl) & $0,1 \pm 0,1$ & $0,1 \pm 0,04$ & $0,1 \pm 0,05$ & 0,659 \\
\hline
\end{tabular}

(*) diferença estatística significante

FA (fosfatase alcalina); AST (aspartato aminotransferase); ALT (alanina aminotransferase) 

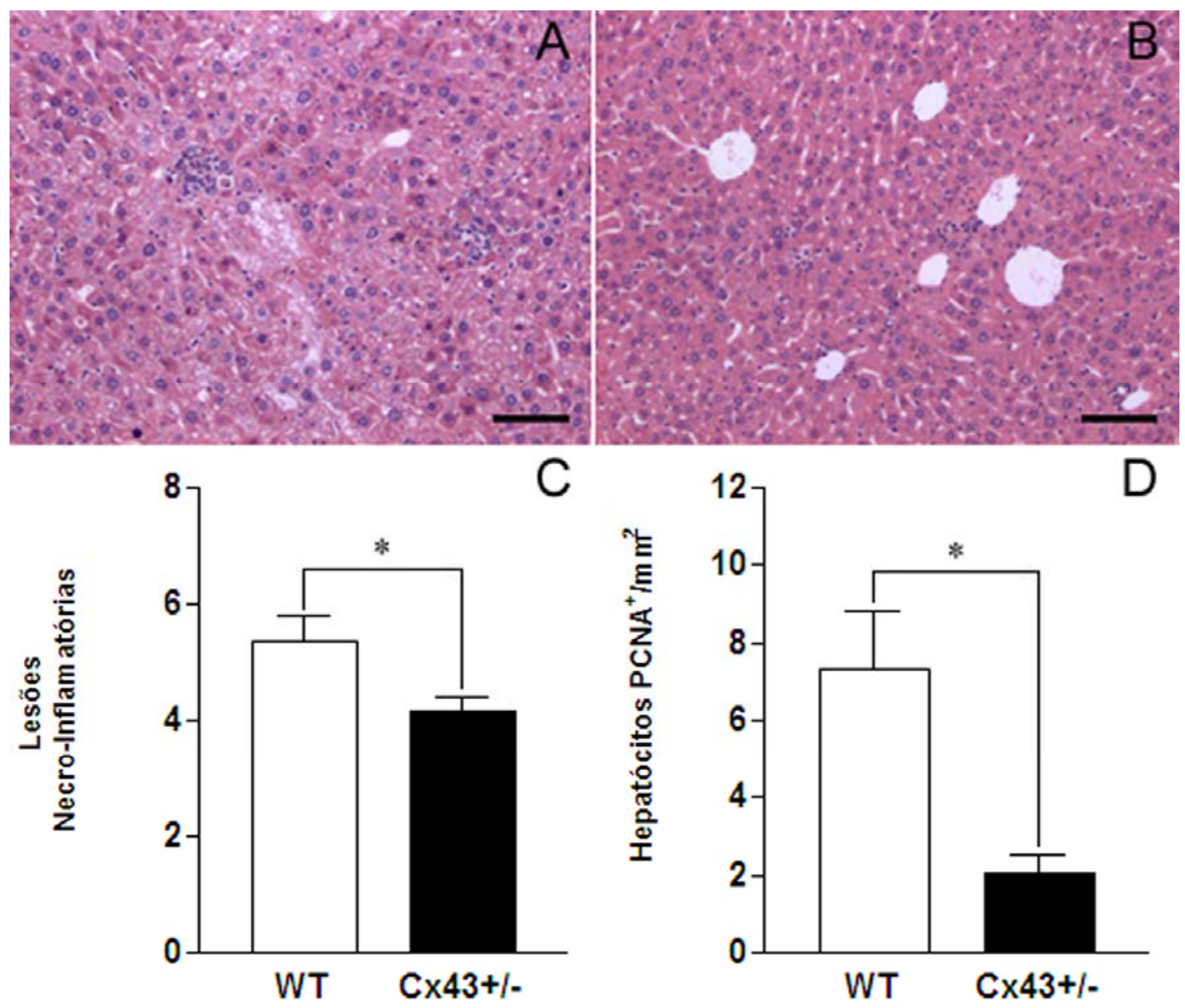

$\mathrm{CCl}_{4}$

$\mathrm{CCl}_{4}$

Figura 22 - As alterações histopatológicas causadas pelo $\mathrm{CCl}_{4}$ nos animais de ambos os genótipos $(\mathrm{n}=10 /$ genótipo $)$ foram observadas em lâminas coradas por hematoxilina-eosina. Os animais $\mathrm{Cx}_{4} 3^{+/-}$apresentaram menos lesões hepatocelulares e infiltrado inflamatório no parênquima hepático. (A) Animal WT fibrótico. (B) Animal $\mathrm{Cx} 43^{+/-}$fibrótico. Barra de escala $=20 \mu \mathrm{m}$. (C) Gráfico com as alterações histopatológicas no tecido hepático, classificadas segundo Ishak et al. (1995), demonstrando que os animais $\mathrm{Cx} 43^{+/-}$apresentaram menos lesões necro-inflamatórias. (*) diferença estatística significante $(p=0,030)$. (D) Gráfico demonstra o índice de proliferação celular dos hepatócitos nos animais fibróticos de ambos os genótipos. Os resultados demonstraram menor proliferação hepatocelular nos animais $\mathrm{Cx} 43^{+/-}$fibróticos em comparação aos animais WT. (*) diferença estatística significante $(p=0,021)$ 


\subsection{APENAS A Cx43 É ALTERADA NA FIBROSE HEPÁTICA MURINA}

As conexinas 43, 32 e 26 foram avaliadas por imuno-histoquímica, western blot e PCR em tempo real para determinar sua participação na fibrose hepática. A técnica de imunohistoquímica foi utilizada para identificar a localização celular das conexinas, as quais podem estar presentes na membrana plasmática ou no citoplasma/núcleo. A localização fora da membrana celular indica que a conexina está sendo produzida, mas não está formando os canais comunicantes. O western blot indica se há comprometimento na concentração da proteína de interesse e o PCR em tempo real identifica alterações em sua expressão gênica. Os dois métodos correlacionam-se pelo fato de uma hiperexpressão não corresponder necessariamente a uma alta concentração de proteínas, pois esta pode ser degradada no citoplasma. Conseqüentemente, a alta concentração de proteína não indica hiperexpressão gênica, pois esta pode estar armazenada no citoplasma ou ainda não ter sido degradada (SILVA, 2008).

A imuno-histoquímica (Figura 23A e B) demonstrou que a maioria das células positivas para $\mathrm{Cx} 43$ estava localizada nos espaços perissinusoidais. No entanto, observou-se que grande parte da imunoreatividade da Cx43 estava aberrantemente presente no citoplasma das células perissinusoidais dos animais fibróticos (Figura 23B). Na análise morfométrica, os animais fibróticos WT e $\mathrm{Cx} 43^{+/-}$apresentaram aumento na área $\mathrm{Cx} 43$-positiva em comparação com os respectivos animais controles (Figura 23C). O western blot para Cx43 (Figura 23D) corroborou os resultados demonstrados pela imuno-histoquímica. Houve diferença na expressão gênica da $\mathrm{Cx} 43$ apenas entre os genótipos (WT vs. $\mathrm{Cx} 43^{+/}$) dos animais fibróticos e controles (Figura 23E).

A reação de imuno-histoquímica para Cx32 demonstrou um padrão normal de distribuição no tecido hepático, em sua maioria localizada na membrana dos hepatócitos (Figura 24A e B). Nos animais fibróticos, de ambos os genótipos, foram observadas proteínas com localização aberrante, as quais se distribuíam no citoplasma ou no núcleo de alguns hepatócitos (Figura 24B - setas). A Cx26 apresentou padrão similar de marcação (Figura 25A e B), porém em menor proporção em relação à Cx32. As expressões gênicas, analisadas por PCR em tempo real (Figuras 24C e 25C), e protéica, analisada por western blot (Figuras 24D e 25D), não apresentaram diferenças entre os animais controles e fibróticos. 

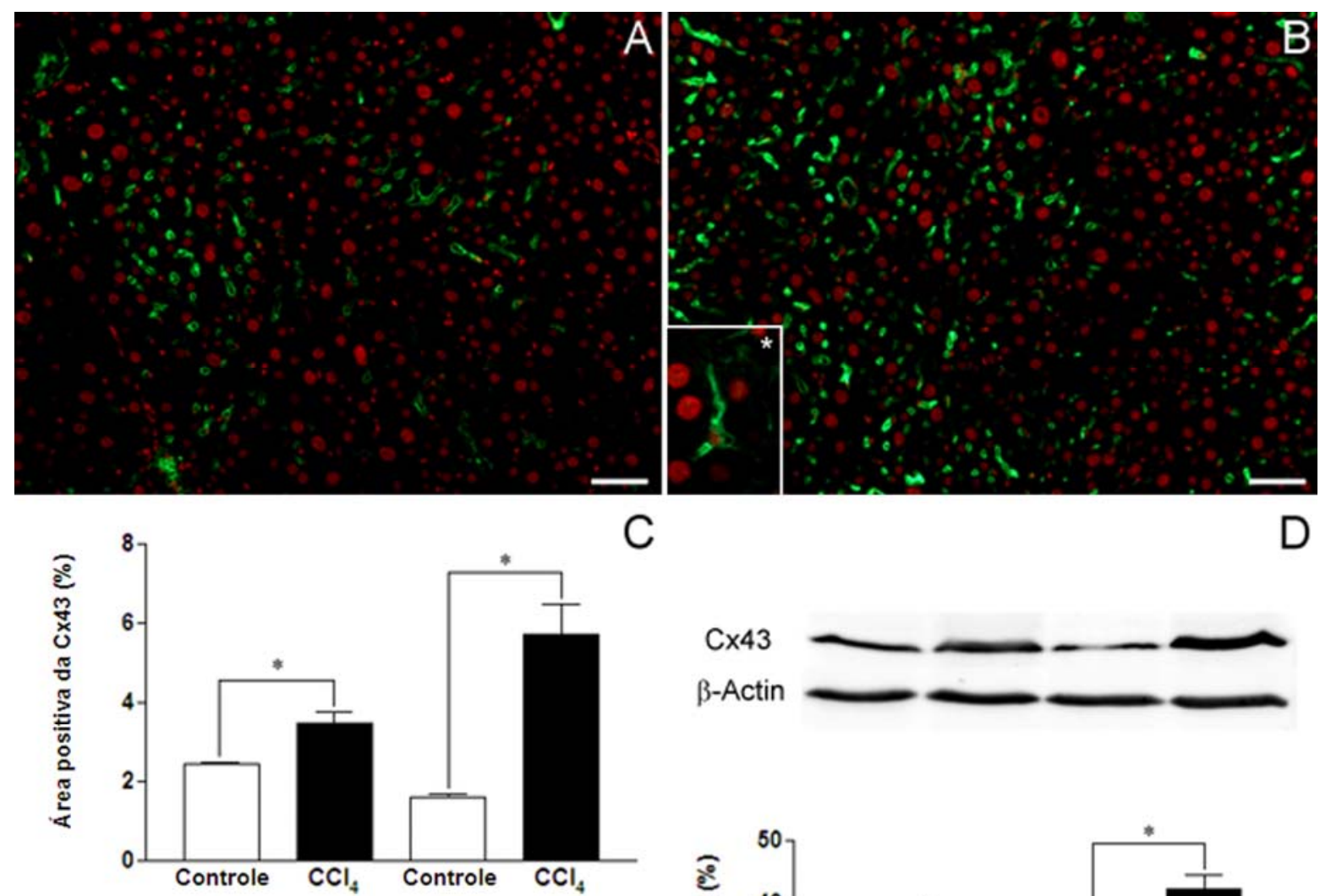

C

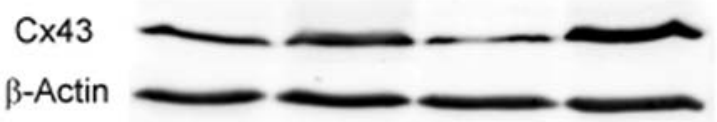

Wild-Type

$\mathrm{C} \times 43+1-$
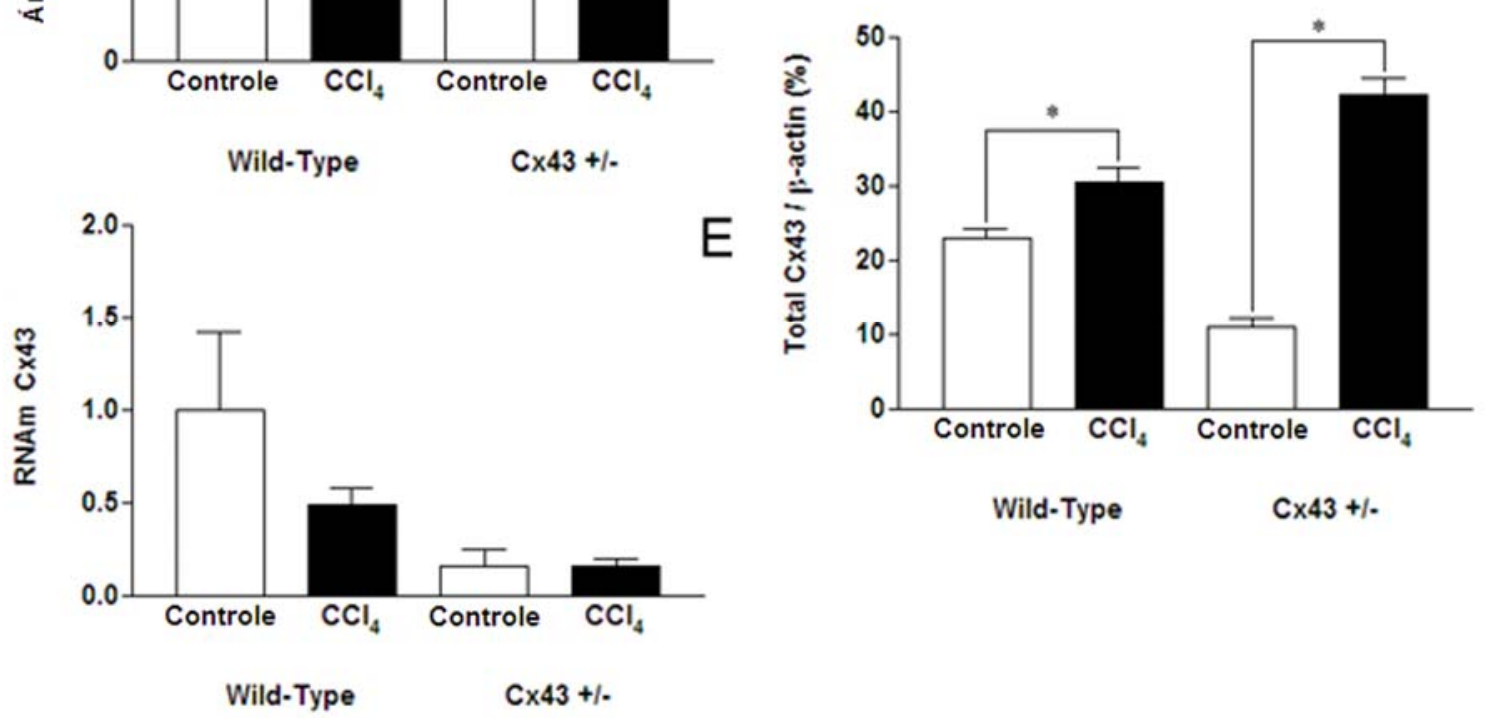

Wild-Type

C $\times 43+1$ -

Figura 23 - Análise das expressões gênica e protéica da $\mathrm{Cx} 43$ em fígado de animais controles e animais fibróticos $\left(\mathrm{CCl}_{4}\right)$ em ambos os genótipos (WT; $\mathrm{Cx} 43^{+/-}, \mathrm{n}=6 /$ genótipo). Os animais $\mathrm{Cx} 43^{+/-}$fibróticos apresentaram maior reatividade da $\mathrm{Cx} 43$ nos espaços perissinusoidais, correspondente à localização das células que normalmente expressam esta conexina. (A) Animal controle. (B) Animal fibrótico. (*) Localização aberrante da $\mathrm{Cx} 43$ no citoplasma de células não-parenquimais. Barra de escala $=20 \mu \mathrm{m}$. (C) Análise morfométrica mostrou o aumento da área de imunomarcação da $\mathrm{Cx} 43$ em animais WT e $\mathrm{Cx} 43^{+/-}$fibróticos quando comparados aos animais controles. (*) diferença estatística significante $(p<0,05)$. (D) Gráfico representa a densitometria relativa da $\mathrm{Cx} 43$ entre os animais controles e fibróticos. $\left(^{*}\right)$ diferença estatística significante $(p<0,05)$. (E) Gráfico demonstra que não existiu diferença significativa na expressão gênica relativa da $C x 43$ entre os animais controles e fibróticos $(p>0,05)$ 

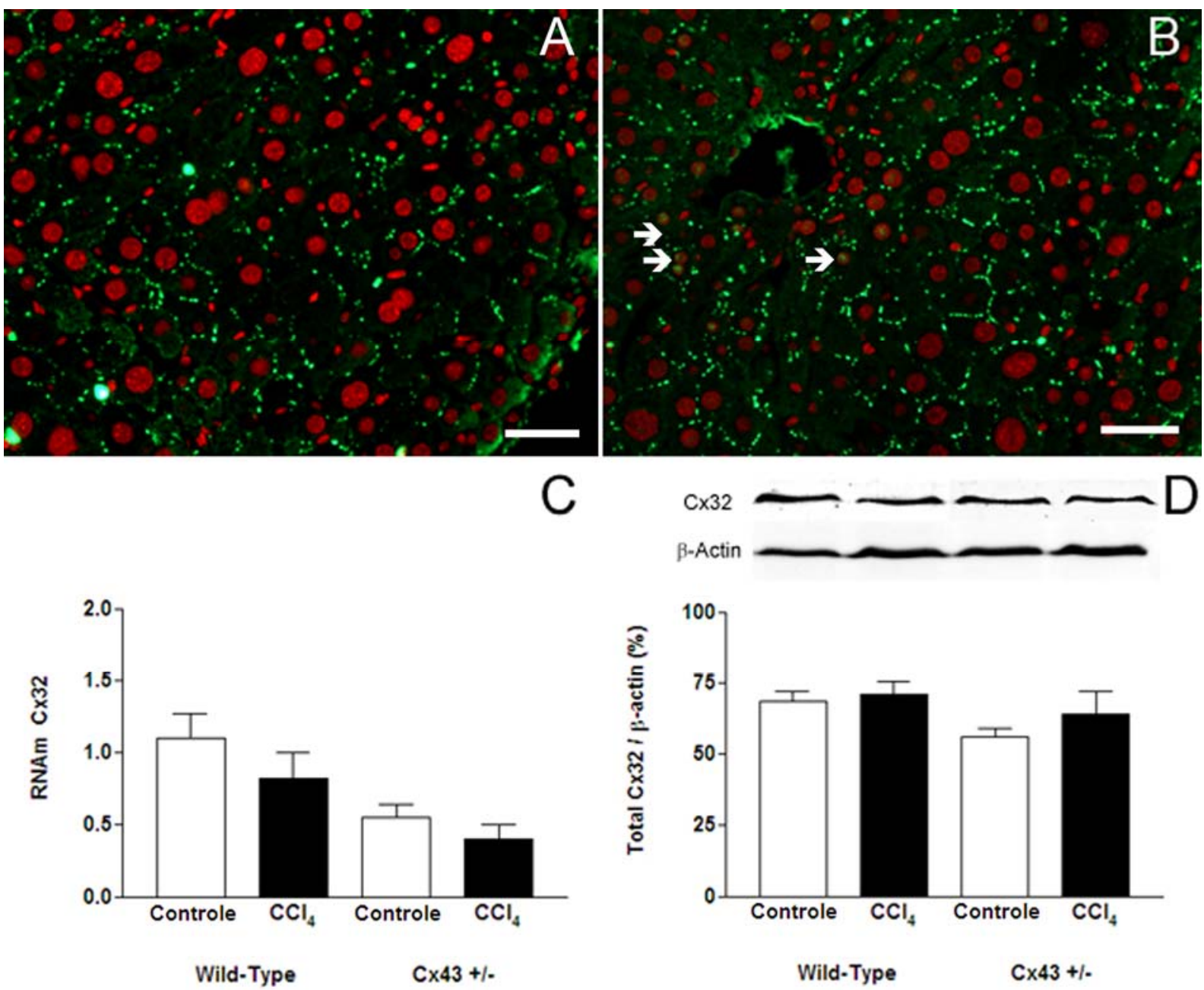

Figura 24 - Análise das expressões gênica e protéica da Cx32 em fígado de animais controles e animais fibróticos $\left(\mathrm{CCl}_{4}\right)$ em ambos os genótipos (WT; $\mathrm{Cx} 43^{+/-}, \mathrm{n}=6 /$ genótipo). A reação imuno-histoquímica para $\mathrm{Cx} 32$ mostrou um padrão normal de distribuição no tecido hepático, com algumas proteínas aberrantemente localizadas no citoplasma ou núcleo de alguns hepatócitos nos animais fibróticos (setas). Não existiu diferença significativa no padrão de marcação entre os animais controles e fibróticos. (A) Animal controle. (B) Animal fibrótico. Barra de escala $=20 \mu \mathrm{m}$. (C) Gráfico demonstra que não existiu diferença significativa na análise da expressão gênica relativa da Cx32 entre os animais controles e fibróticos $(p>0,05)$. (D) Gráfico demonstra que não existiu diferença significativa na análise da densitometria relativa da Cx32 entre os animais controles e fibróticos $(p>0,05)$ 

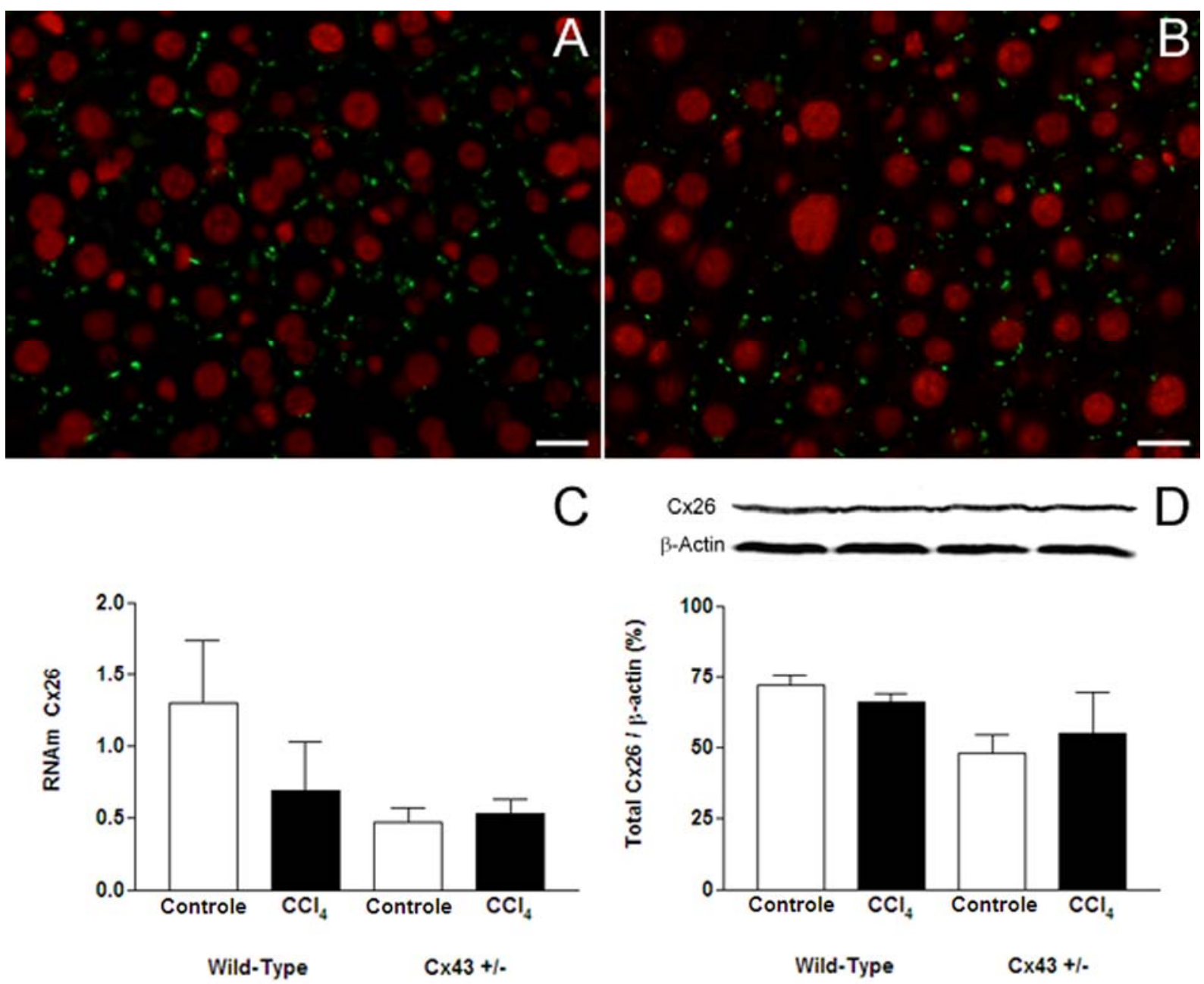

Figura 25 - Análise das expressões gênica e protéica da Cx26 em fígado de animais controles e animais fibróticos $\left(\mathrm{CCl}_{4}\right)$ em ambos os genótipos (WT; $\mathrm{Cx} 43^{+/-}, \mathrm{n}=6 /$ genótipo). A reação imuno-histoquímica para Cx26 mostrou um padrão normal de distribuição no tecido hepático. Não existiu diferença significativa no padrão de marcação entre os animais controles e fibróticos. (A) Animal controle. (B) Animal fibrótico. Barra de escala $=10 \mu \mathrm{m}$. (C) Não existiu diferença significativa na análise da expressão gênica relativa da Cx26 entre os animais controles e fibróticos $(p>0,05)$. (D) Não existiu diferença significativa na análise da densitometria relativa da Cx26 entre os animais controles e fibróticos $(p>0,05)$ 


\subsection{DEFICIÊNCIA DE Cx43 ALTERA OS MECANISMOS MOLECULARES RELACIONADOS À FIBROGÊNESE E FIBRÓLISE DA MEC HEPÁTICA}

Foi realizada análise da expressão dos principais genes envolvidos na deposição de colágeno no tecido hepático, assim como os genes envolvidos na degradação e remoção da matriz extracelular no fígado fibrótico (Figura 26A-G).

Inicialmente, foi analisada a expressão da proteína de citoesqueleto alfa-actina de músculo liso ( $\alpha$-SMA), marcador da ativação das células estreladas hepáticas, além de outras células envolvidas na fibrogênese, em miofibroblastos. Esta análise demonstrou que os animais fibróticos apresentaram aumento na expressão gênica de $\alpha$-SMA em relação aos animais controles, indicando a ativação das células produtoras de colágeno. No entanto, não foi observada diferença estatística entre os genótipos (WT vs. $\mathrm{Cx} 43^{+/}$) dos animais fibróticos (Figura 26A).

A análise transcricional do gene do colágeno tipo I demonstrou um expressivo aumento em sua expressão (> 10 vezes) no animais fibróticos em relação aos animais controles. No entanto, a expressão deste gene foi menor nos animais $\mathrm{Cx} 43^{+/}$fibróticos em relação aos animais WT fibróticos (Figura 26B). A expressão gênica do TGFß-1 (Figura 26C), principal fator pró-fibrogênico, apresentou comportamento semelhante em relação seu gene alvo (colágeno tipo I).

A expressão gênica das metaloproteinases 2 e 13 (MMPs-2 e -13), assim como do inibidor tecidual de metaloproteinases 1 (TIMP-1) foi maior nos animais fibróticos em relação aos animais controles (Figura 26D-F). No entanto, os animais Cx $43^{+/-}$fibróticos apresentaram menor expressão desses genes quando comparado aos animais WT fibróticos (Figura 26). Importante atenção para a expressão gênica de TIMP-1, que apresentou expressivo aumento em relação aos animais controles (> 10 vezes) (Figura 26D). A análise transcricional do ativador de plaminogênio tipo uroquinase (uPA) apresentou-se aumentado nos animais fibróticos, porém não revelou diferença entre os genótipos dos animais fibróticos (Figura 26G). Analisando os animais controle, foi observada diferença entre os genótipos WT e $\mathrm{Cx} 43^{+/-}$apenas em relação aos genes da MMP-2, uPA e $\alpha$-SMA. 

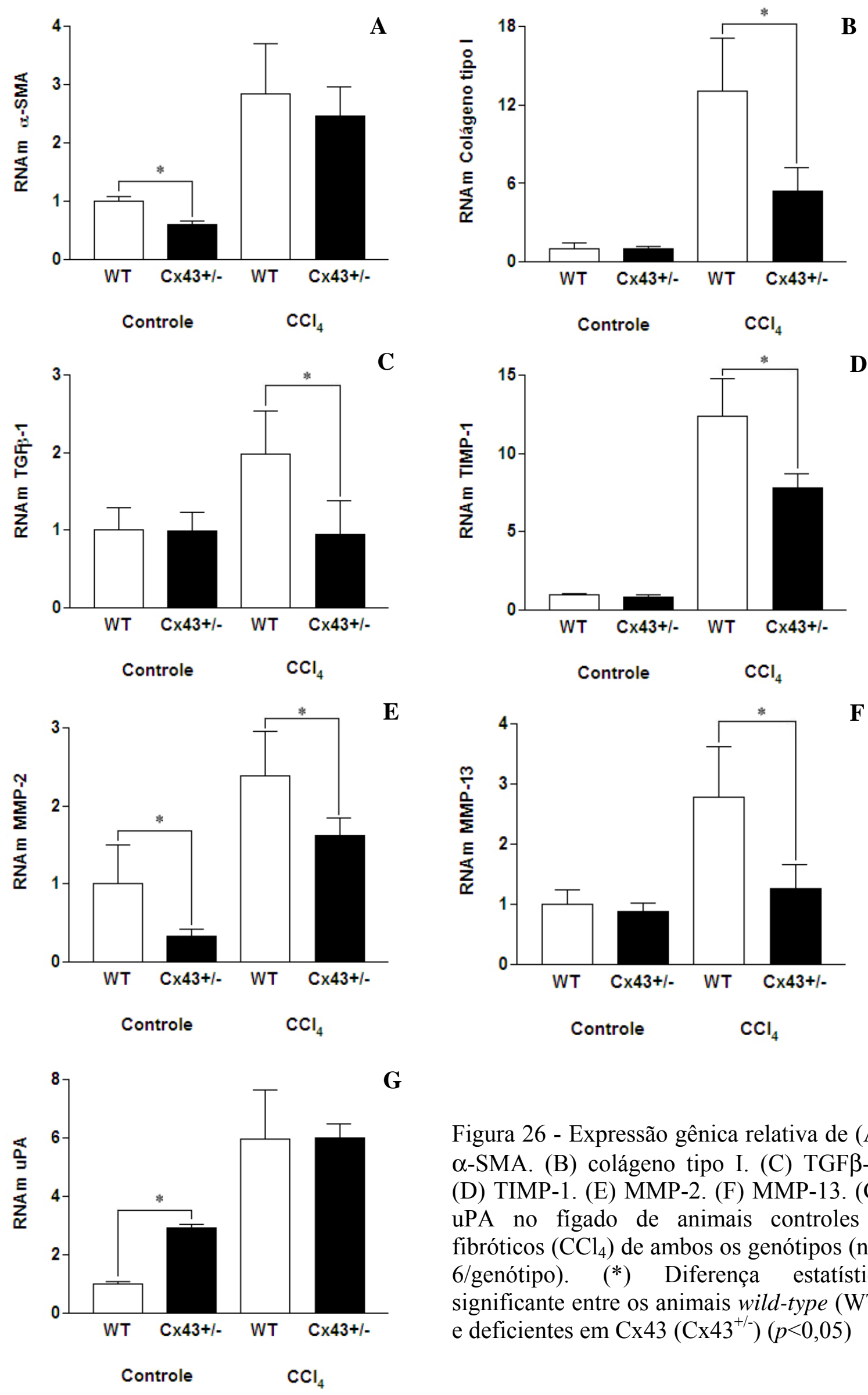

Figura 26 - Expressão gênica relativa de (A) $\alpha$-SMA. (B) colágeno tipo I. (C) TGF $\beta-1$. (D) TIMP-1. (E) MMP-2. (F) MMP-13. (G) uPA no fígado de animais controles e fibróticos $\left(\mathrm{CCl}_{4}\right)$ de ambos os genótipos $(\mathrm{n}=$ 6/genótipo). (*) Diferença estatística significante entre os animais wild-type (WT) e deficientes em $\mathrm{Cx} 43\left(\mathrm{Cx} 43^{+/}\right)(p<0,05)$ 
Animais Knockout

$$
\text { para Cx32 }
$$

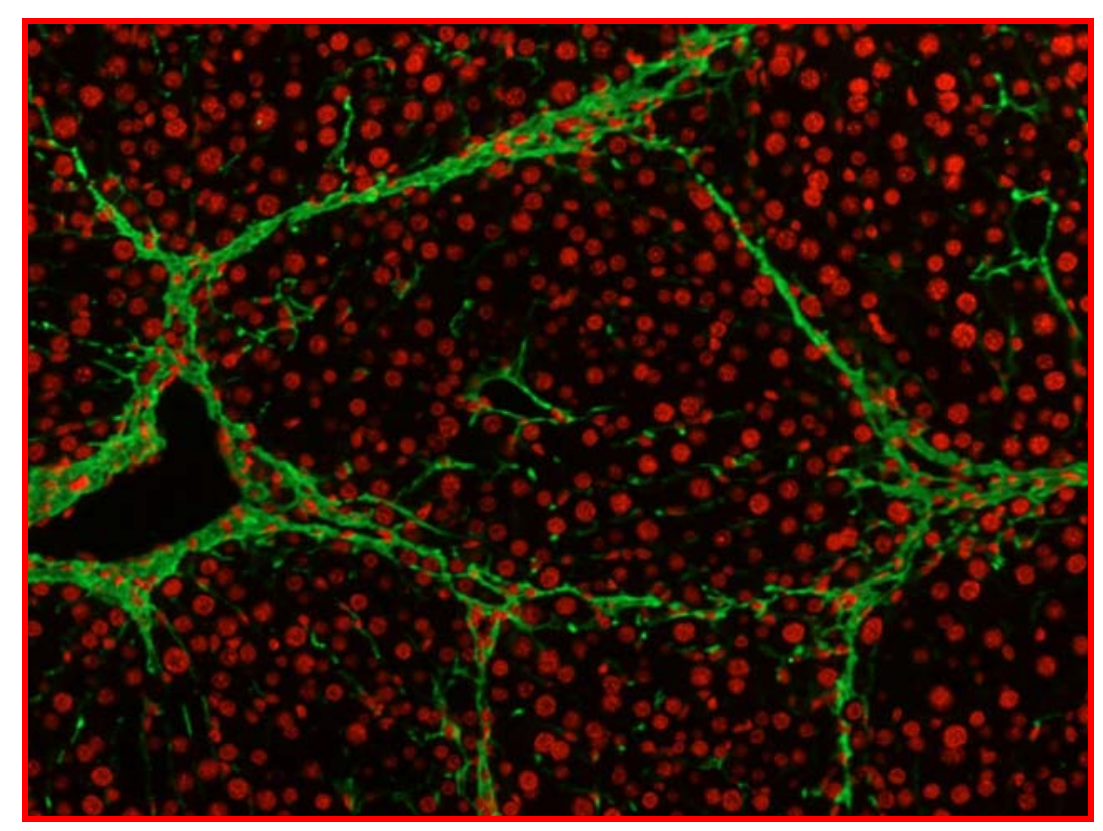




\subsection{AUSÊNCIA DE Cx32 AUMENTA DEPOSIÇÃO DE COLÁGENO}

A análise comparativa dos parâmetros biométricos, tais como peso do fígado e os índices hepáticos relacionados ao peso vivo e corpóreo, não demonstrou diferença estatística entre os diferentes genótipos dos animais fibróticos (Figura 27).

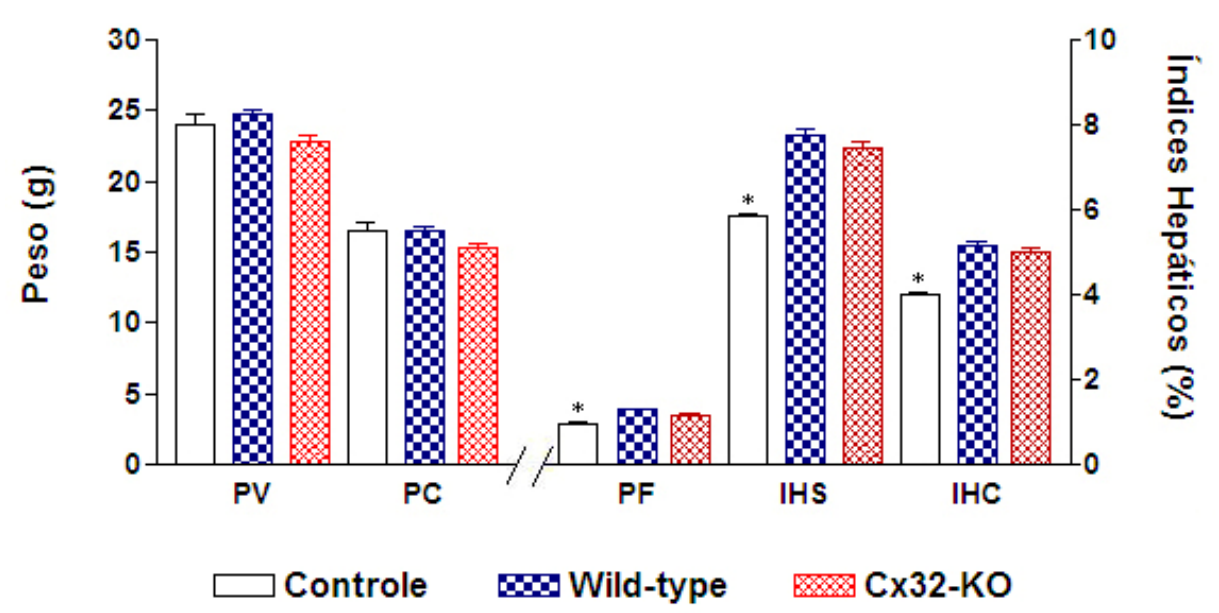

Figura 27 - Parâmetros biométricos obtidos após a eutanásia dos camundongos Wild-type (WT) e knockout (Cx32-KO) submetidos ao modelo de fibrose hepática pelo $\mathrm{CCl}_{4}(\mathrm{n}=10$ /genótipo). PV: Peso Vivo; PC: Peso Corporal; PF: Peso do Fígado; IHS: Índice Hepatossomático; IHC: Índice Hepatocorporal

Em relação aos aspectos macroscópicos, os animais fibróticos de ambos os genótipos apresentaram um processo de micronodulação superficial, com comprometimento de bordos e retração da cápsula hepática. No entanto, não foram observadas diferenças no padrão morfológicos das lesões hepáticas entre os genótipos dos animais com fibrose hepática (Figura 28A-F). As lâminas coradas pela técnica de picrossírius e analisadas segundo os critérios modificados por Ishak et al. (1995), não demonstraram diferença significante no estadiamento do grau da fibrose hepática entre os genótipos (Figura 29A). No entanto, após a morfometria das fibras colágenas coradas pelo picrossírius, observou-se que os animais knockout (Cx32-KO) apresentaram aumento de 23,7\% na proporção volumétrica de colágeno no tecido hepático em relação aos animais WT fibróticos (Figura 29B-D). A reação de imunofluorescência para o colágeno tipo I (Figura 30A e B) também demonstrou que, apesar do mesmo estadiamento da fibrose, os animais Cx32-KO apresentaram maior densidade de colágeno nas pontes fibrosas entre e ao redor dos espaços vasculares (Figura 30B). Os animais 
Cx32-KO fibróticos apresentaram maior expressão gênica do colágeno tipo I em relação aos animais WT fibróticos, no entanto, não houve diferença na expressão gênica da MMP-2 entre os genótipos (Figura 31).

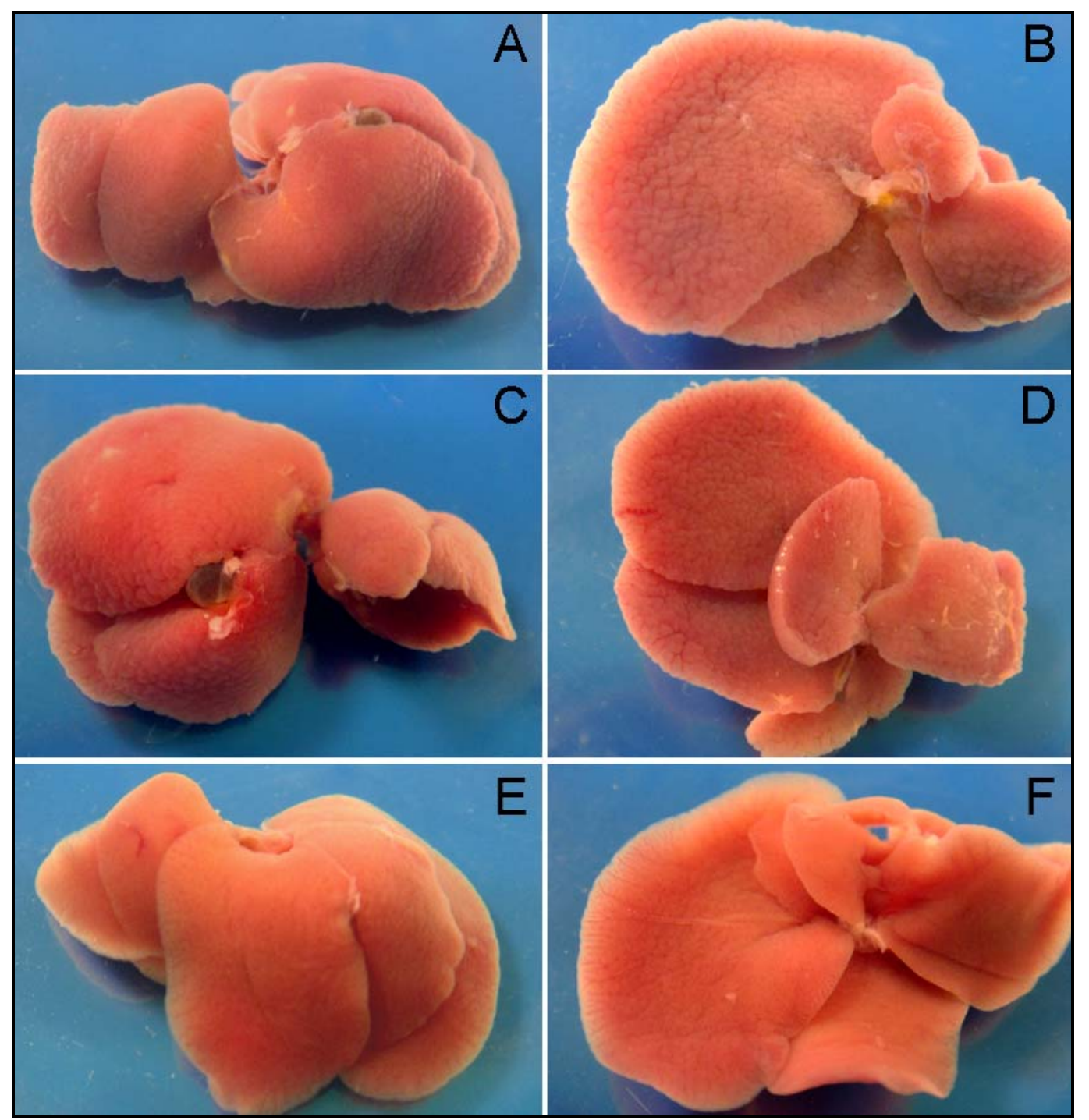

Figura 28 - Fotomacrografias do fígado de animais WT e knockouts para Cx32 (n = 10/genótipo), submetidos ao modelo de fibrose hepática pelo $\mathrm{CCl}_{4}$. (A-B) Animais WT fibróticos; (B-C) Animais Cx32-KO fibróticos; (E-F) Animais controles. Em relação aos aspectos macroscópicos, os animais fibróticos de ambos os genótipos apresentaram um processo de micronodulação superficial, com comprometimento de bordos e retração da cápsula hepática, diferentemente dos animais controles. No entanto, não foi possível identificar diferenças no padrão morfológico das lesões hepáticas entre os diferentes genótipos dos animais fibróticos 

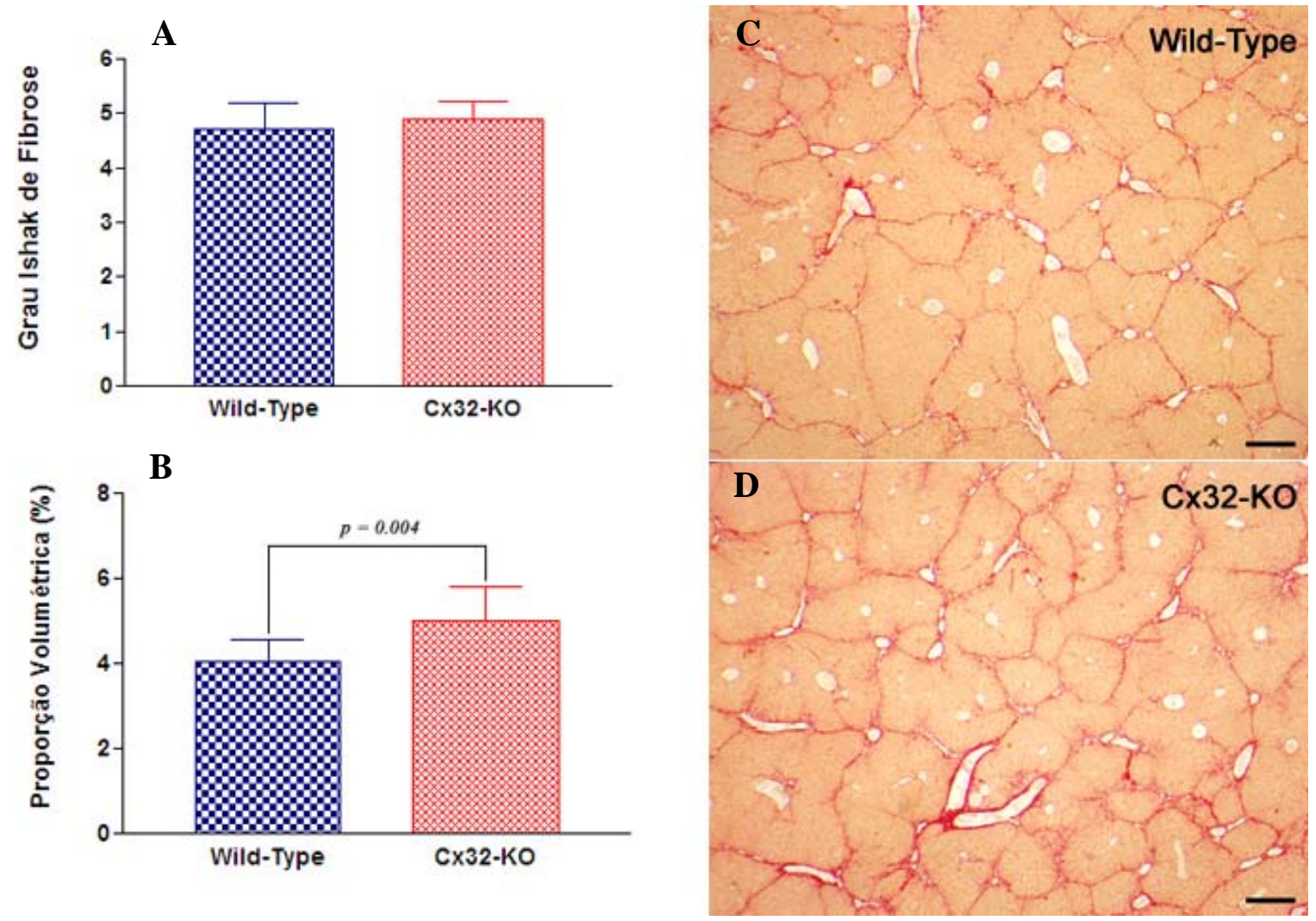

Figura 29 - (A) Estadiamento do tecido hepático dos camundongos submetidos ao modelo de fibrose hepática, classificado segundo os critérios modificados por Ishak et al. (1995). (B) Proporção volumétrica da área ocupada pelo colágeno no parênquima hepático no diferentes genótipos, analisado pela morfometria das fibras coradas em vermelho na coloração de picrossírius. Houve diferença estatística entre os genótipos dos animais fibróticos $(p=0,004)$. (C) Fotomicrografias demonstrando as pontes de colágeno entre os espaços vasculares no fígado dos camundongos wildtype submetidos ao modelo de fibrose pelo $\mathrm{CCl}_{4}$ e (D) $\mathrm{Cx} 32-\mathrm{KO}$, que apresentaram uma maior densidade volumétrica dos septos fibrosos. $n=10$ /genótipo. Barra de escala $=150 \mu \mathrm{m}$ 


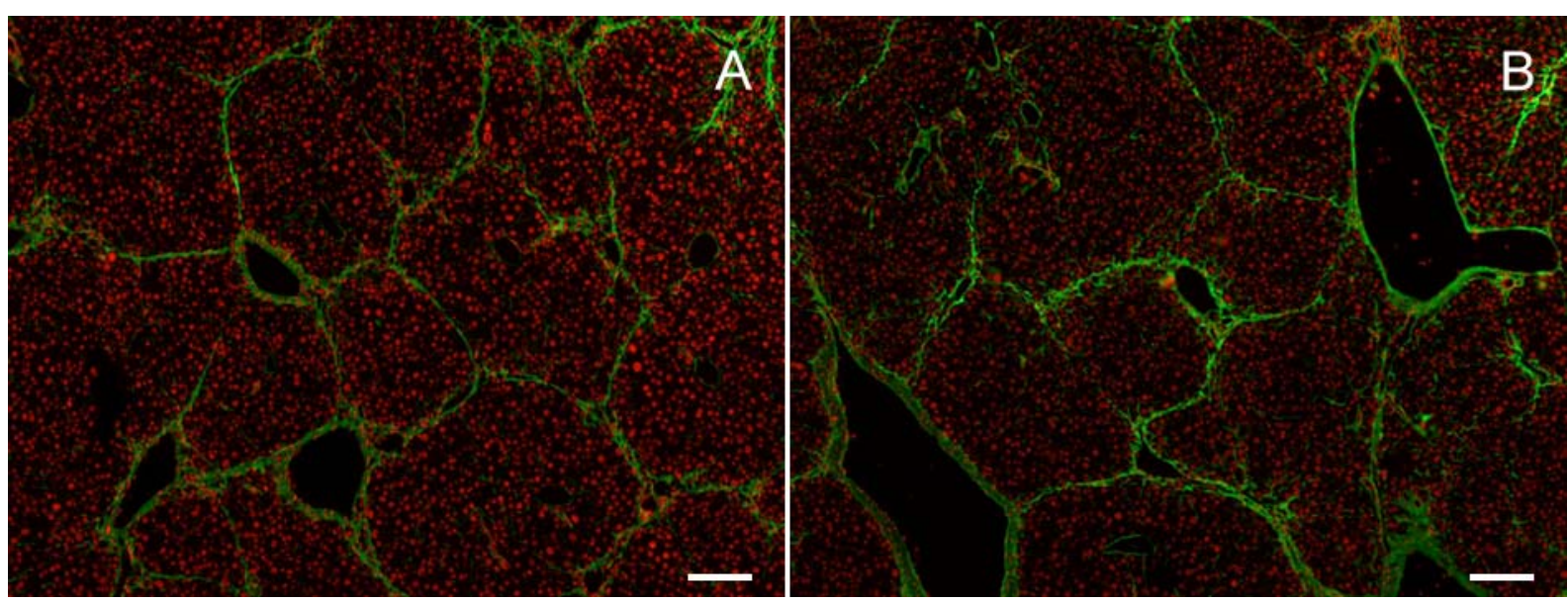

Figura 30 - Imunofluorescência para colágeno tipo I no tecido hepático fibrótico de camundongos WT e KO-Cx32 ( $\mathrm{n}=10 /$ genótipo). (A) Animal wild-type. Podese observar a presença de septos fibrosos no tecido hepático, formando pontes entre os espaços vasculares, culminando na delimitação de nódulos hepáticos bem definidos. (B) Animal Cx32-KO. Apresentou as mesmas características dos animais wild-type, porém os septos fibrosos são mais denso, com maior deposição de colágeno tipo I. Barra de escala $=50 \mu \mathrm{m}$. Contra-coloração nuclear com iodeto de propídeo

Colágeno tipo I

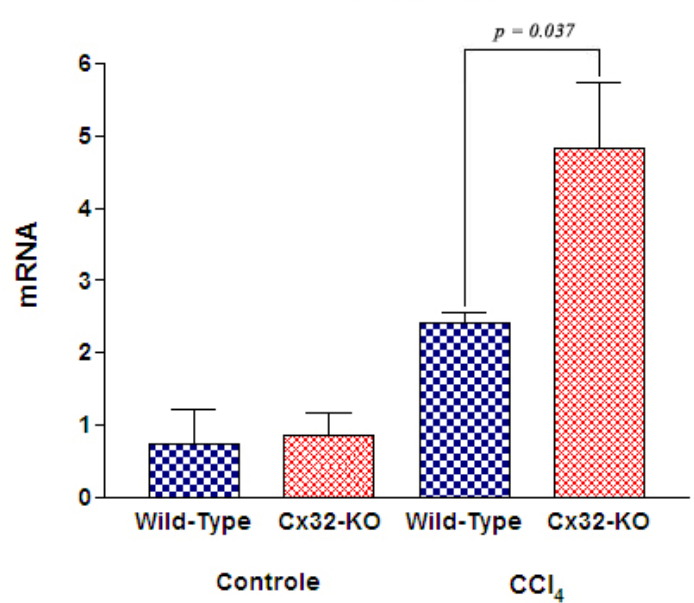

MMP - 2

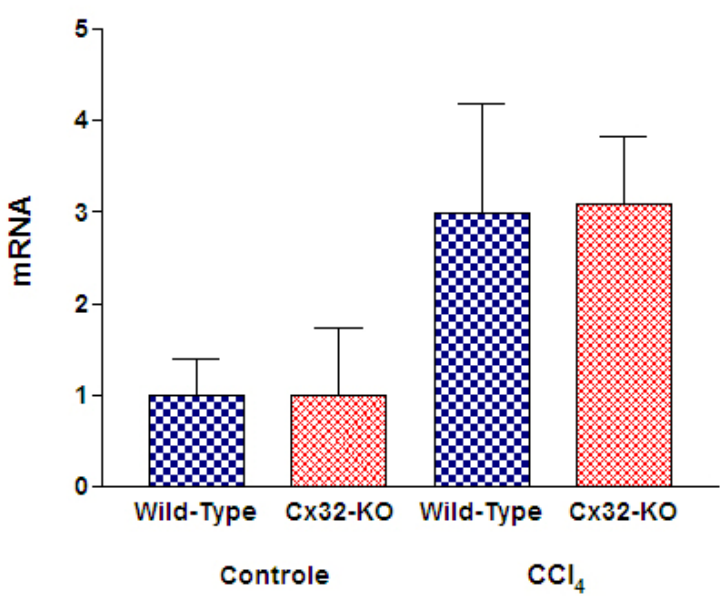

Figura 31 - Expressão gênica relativa do colágeno tipo I e da metaloproteinase 2 (MMP-2) no fígado de animais controle e fibróticos de ambos os genótipos $(\mathrm{n}=6 /$ genótipo $)$. Diferença estatística significante $(p=0,037)$. A MMP-2 não apresentou diferença estatística entre os diferentes genótipos $(p>0,05)$ 


\subsection{AUSÊNCIA DE Cx32 EXACERBA INJÚRIA HEPÁTICA E ALTERA BALANÇO ENTRE PROLIFERAÇÃO CELULAR E APOPTOSE}

Segundo os critérios de atividade necro-inflamatória estabelecidos por Knodell et al. (1981) e modificados por Ishak et al. (1995), o índice de atividade histológica demonstrou que os animais knockout para Cx32 apresentaram aumento significativo de 20,4\% na atividade histológica tecidual em relação aos animais WT, indicando maior número de lesões hepáticas em resposta à injúria crônica pelo $\mathrm{CCl}_{4}$ (Figuras 32 e 33). Conseqüentemente, estes animais apresentaram elevação nos níveis séricos das enzimas hepáticas AST, ALT e fosfatase alcalina. Os animais knockout fibróticos apresentaram aumento de 33,2\% na concentração sérica de AST, aumento de 19,2\% na concentração sérica de ALT e aumento de 13,7\% na concentração sérica da fosfatase alcalina em relação aos animais WT fibróticos. Os demais parâmetros, como albumina, proteína total e bilirrubina total não apresentaram diferença entre os genótipos (Tabela 3).
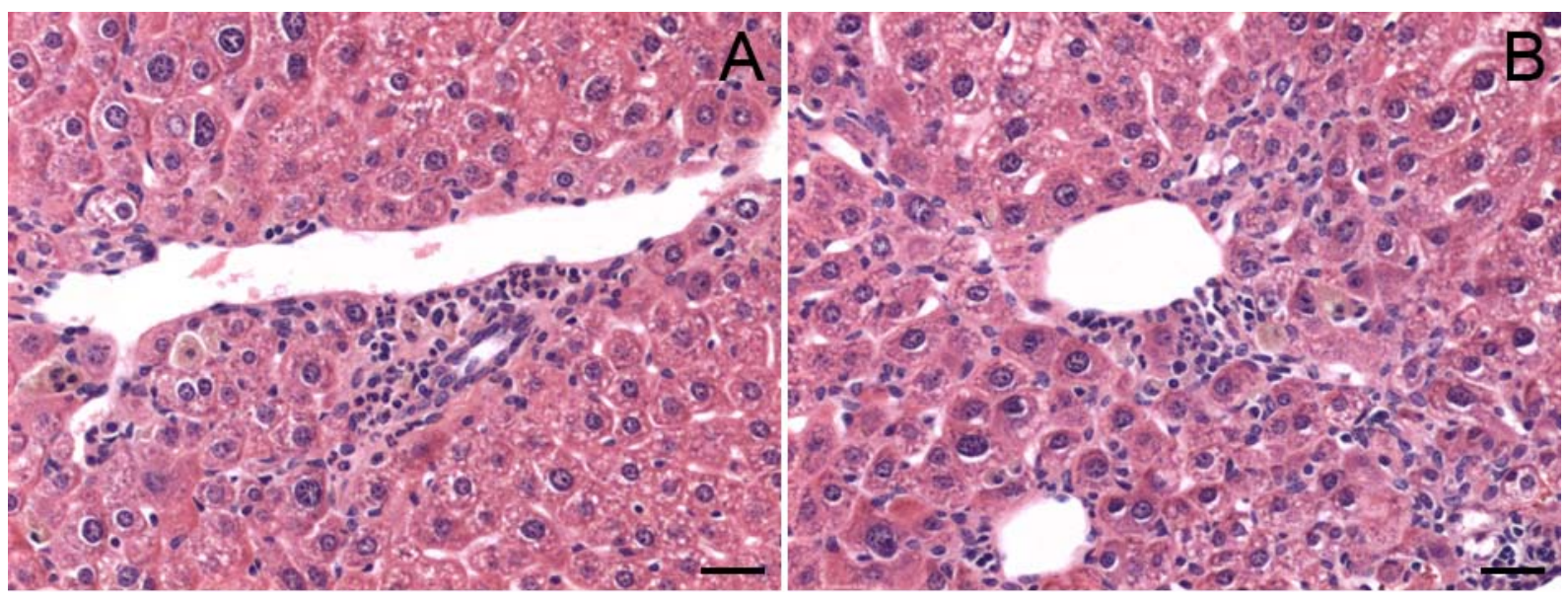

Figura 32 - Fotomicrografias do tecido hepático dos camundongos submetidos ao modelo de fibrose hepática ( $n=10$ /genótipo). Detalhes do infiltrado perivascular e necrose em saca-bocados, mostrando atividade moderada nos animais WT (A) e intensa nos animais Cx32-KO (B). HE. Barra de escala $=20 \mu \mathrm{m}$ 


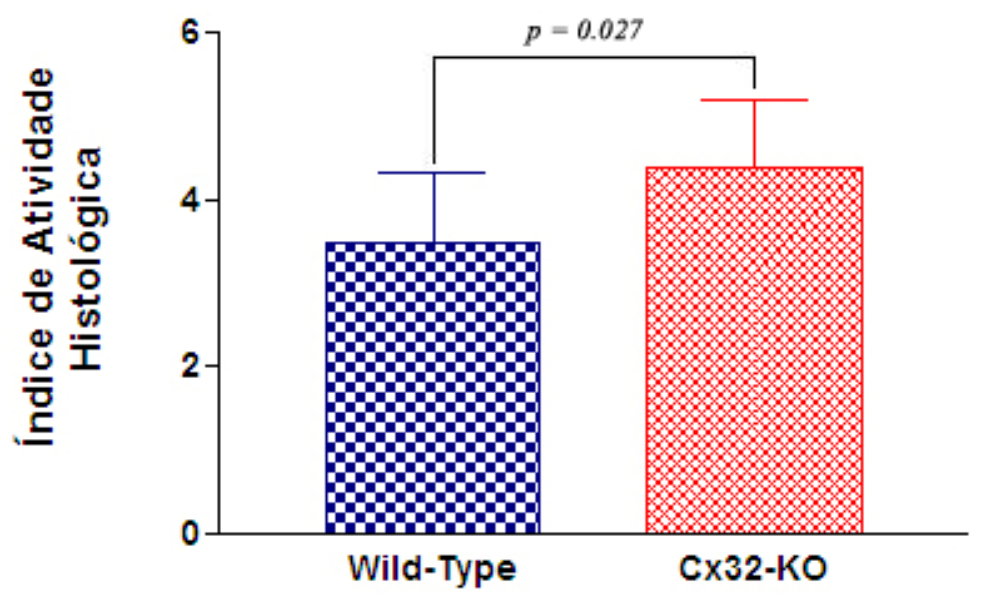

Figura 33 - Índice de atividade histológica do tecido hepático dos camundongos submetidos ao modelo de fibrose hepática ( $\mathrm{n}=10 /$ genótipo), demonstrando a atividade necro-inflamatória tecidual classificada segundo os critérios de Ishak et al. (1995) $(p=0,027)$

Tabela 3 - Parâmetros da função bioquímica hepática em animais controles e animais knockouts para Cx32 e WT fibróticos (n=10/genótipo) - São Paulo - 2009.

\begin{tabular}{ccccc}
\hline Parâmetros & $\begin{array}{c}\text { Animais } \\
\text { Controles }\end{array}$ & $\begin{array}{c}\text { Animais WT } \\
\text { Fibróticos }\end{array}$ & $\begin{array}{c}\text { Animais } \\
\text { Cx32-KO } \\
\text { Fibróticos }\end{array}$ & p-value \\
\hline FA (U/L) & $102,7 \pm 7,8$ & $83,6 \pm 4,2$ & $96,8 \pm 11,6$ & $0,016^{*}$ \\
AST (U/L) & $72,6 \pm 2,5$ & $87,8 \pm 10,9$ & $117,1 \pm 19,7$ & $0,004^{*}$ \\
ALT (U/L) & $48,3 \pm 4,5$ & $55,4 \pm 4,3$ & $68,5 \pm 5,4$ & $0,000^{*}$ \\
Albumina (g/dl) & $1,2 \pm 0,3$ & $1,4 \pm 0,1$ & $1,4 \pm 0,1$ & 0,949 \\
Proteína total (g/dl) & $5,1 \pm 0,2$ & $5,4 \pm 0,2$ & $5,3 \pm 0,2$ & 0,658 \\
Bilirrubina total (mg/dl) & $0,1 \pm 0,03$ & $0,1 \pm 0,03$ & $0,1 \pm 0,04$ & 0,989 \\
\hline
\end{tabular}

* Significância em relação ao WT fibrótico

FA (fosfatase alcalina); AST (aspartato aminotransferase); ALT (alanina aminotransferase). 
A proliferação dos hepatócitos foi analisada pela reação imuno-histoquímica para o antígeno nuclear de proliferação celular (PCNA), sendo quantificado o número de células positivas por $\mathrm{mm}^{2}$ de tecido hepático. Os resultados demonstraram menor proliferação celular dos hepatócitos no animais Cx32-KO fibróticos, com redução de 47,5\% em relação aos animais WT fibróticos (Figura 34). Da mesma forma, a presença de corpúsculos apoptóticos foi analisada nas lâminas coradas em HE e visualizadas sob microscopia de fluorescência. Esta metodologia baseia-se na propriedade da eosina, presente nos corpúsculos apoptóticos, fluorescer quando exposta à luz ultravioleta (Figura 35), sendo útil para identificar as fases finais da apoptose (WOOD; SARMA; ARCHER, 1999). Após a quantificação, foi demonstrado que os animais knockouts fibróticos apresentaram aumento de 40,3\% na quantidade de corpúsculos apoptóticos no tecido hepático (Figura 36), representando assim, uma maior taxa de apoptose quando comparado com os animais wild-type fibróticos.

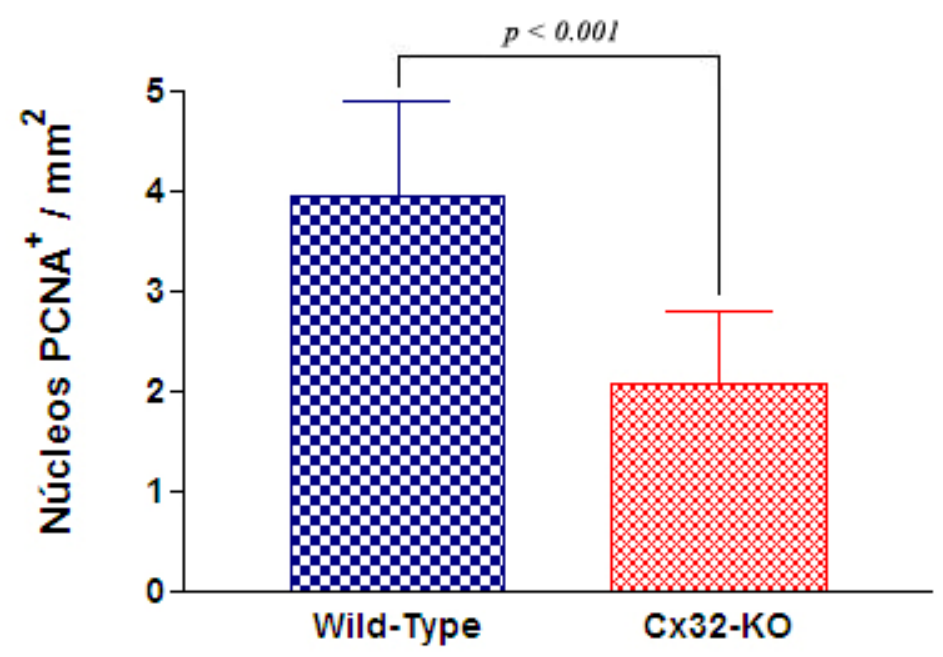

Figura 34 - Índice de proliferação celular dos hepatócitos $/ \mathrm{mm}^{2}$ de tecido hepáticos nos animais WT e Cx32-KO submetidos ao modelo de fibrose hepática ( $\mathrm{n}=$ $10 /$ genótipo $)(p<0,001)$ 


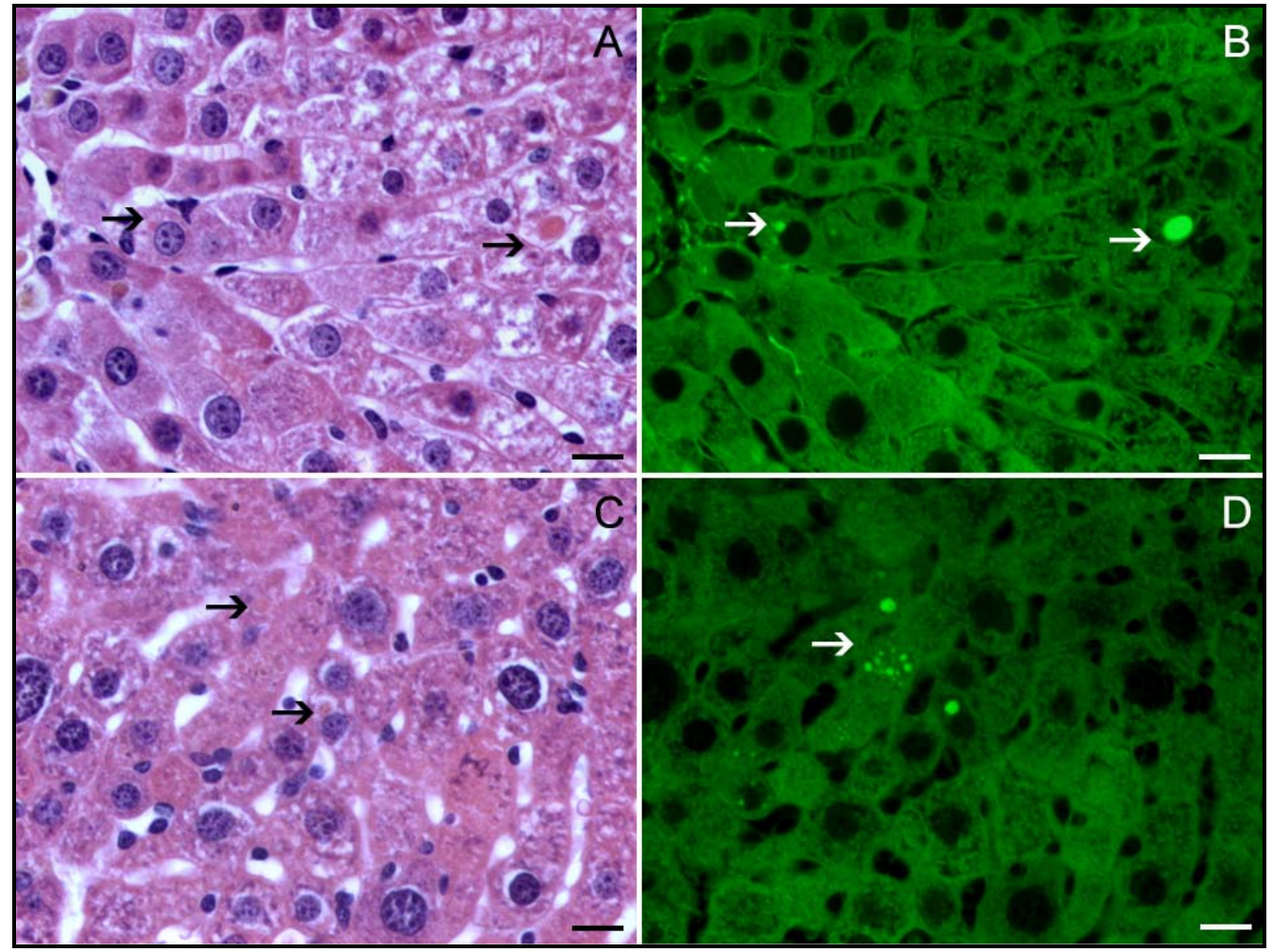

Figura 35 - Fotomicrografias do tecido hepático corado em HE e visualizado em microscopia de luz convencional (A-C) ou sob fluorescência (C-D). As fotos A e B representam o mesmo campo histológico de um animal WT, enquanto as fotos $\mathrm{C}$ e $\mathrm{D}$ representam um animal knockout para Cx32. Observe a maior quantidade de corpúsculos apoptóticos fluorescendo no tecido $(n=10 /$ genótipo). Barra de escala $=5 \mu \mathrm{m}$

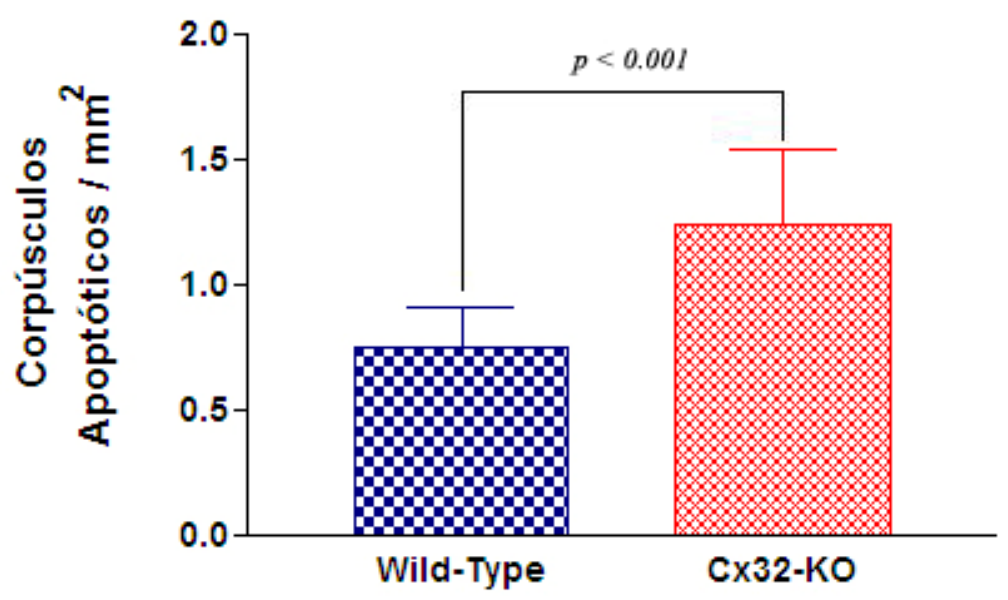

Figura 36 - Quantificação dos corpúsculos apoptóticos por $\mathrm{mm}^{2}$ no tecido hepático de animais WT e Cx32-KO ( $n=10 /$ genótipo) $(p<0,001)$ 


\subsection{AUSÊNCIA DE Cx32 REDUZ A COMUNICAÇÃO INTERCELULAR PELAS JUNÇÕES DO TIPO GAP}

As reações de imuno-histoquímica para as conexinas demonstraram que os animais wild-type controles apresentaram um padrão normal de imunomarcação das Cx32 e 26 no tecido hepático, com distribuição homogênea e membranosa (Figura 37A e D). No entanto, os animais wild-type fibróticos apresentaram marcação imuno-histoquímica irregular e reduzida das Cx32 e 26 no tecido hepático (Figura 37B e E). Os animais Cx32-KO fibróticos praticamente não apresentam reação tecidual das conexinas 32 e 26 (Figura 37C e F), assim como os animais $\mathrm{Cx} 32-\mathrm{KO}$ controle (dados não mostrados). Diferentemente dos animais heterozigotos para $\mathrm{Cx} 43$, estes animais aparentemente não apresentaram envolvimento da Cx43 no processo de fibrose hepática, uma vez que não foi possível observar diferença entre os genótipos (dados não mostrados).

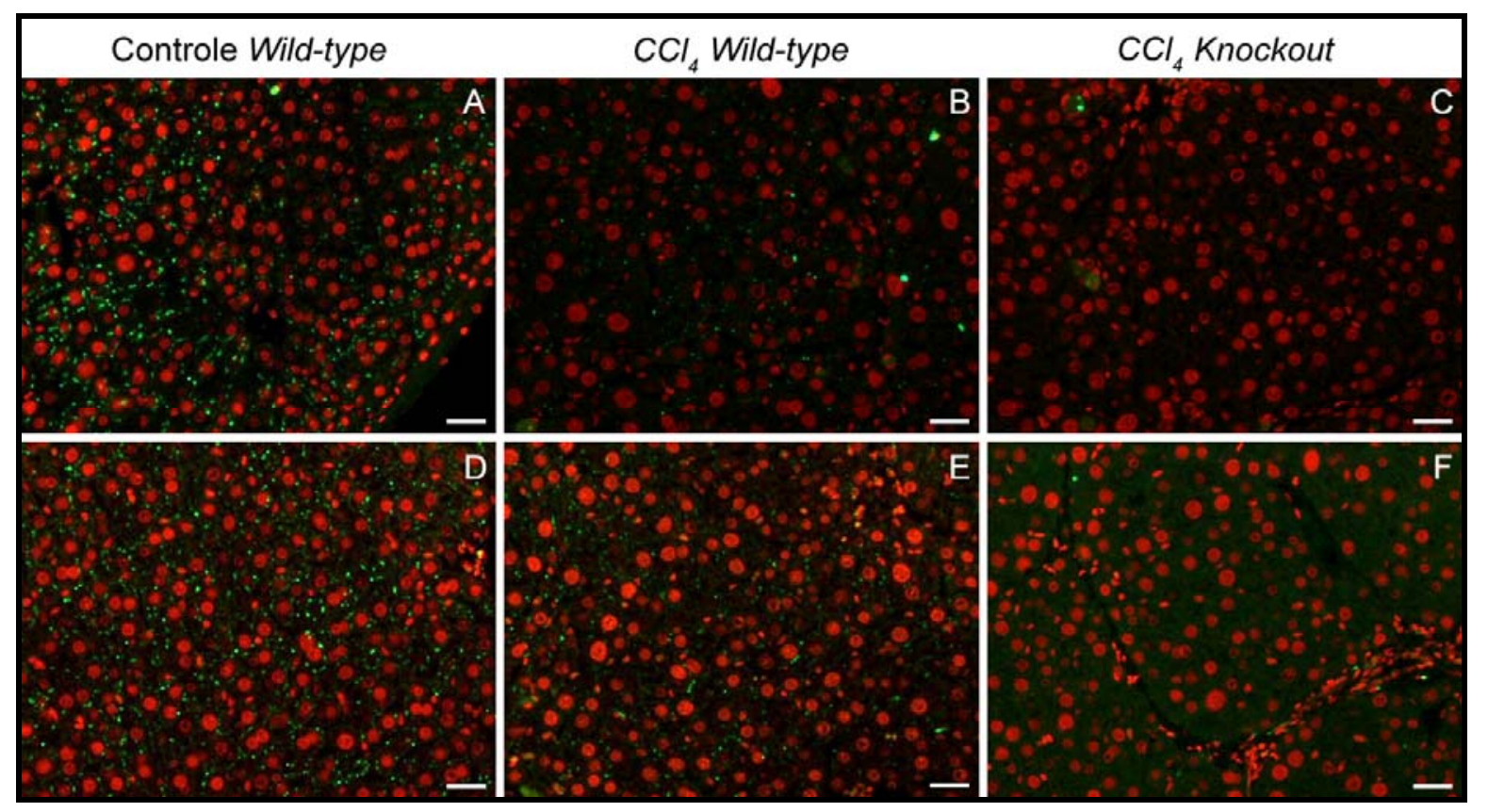

Figura 37 - Imunofluorescência para as conexinas 32 e 26. (A a C) Imunofluorescência para Cx32; (D a F) Imunofluorescência para Cx26 ( $=10$ /genótipo). Barras de escala = $20 \mu \mathrm{m}$. Contra-coloração nuclear com Iodeto de Propídeo 
As reações de western blot demonstraram que a expressão protéica de conexina 43 não apresentou variação entre os genótipos ou entre os grupos. Nos grupos de animais controles e fibróticos, os animais Cx32-KO não apresentaram expressão da conexina 32 e apresentaram acentuada redução da expressão protéica da Cx26 (Figura 38). A análise por PCR em tempo real demonstrou diferença estatística apenas na expressão gênica das conexinas 32 e 26 entre os animais WT e Cx32-KO. Assim como no western blot, não houve diferença estatística na expressão gênica da Cx43 entre os diferentes genótipos (Figura 39).
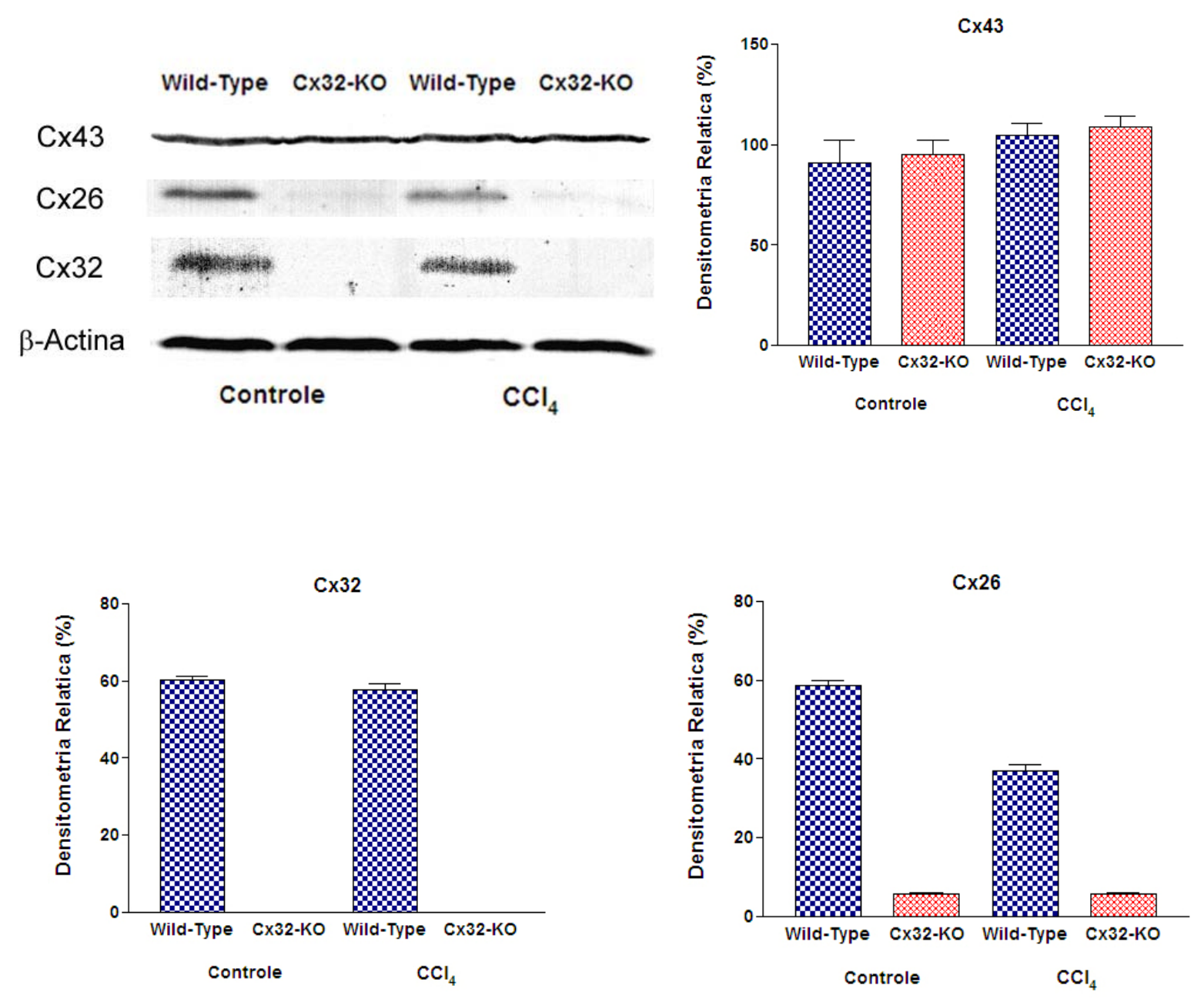

Figura 38 - Western blot e gráficos representando a densitometria da expressão protéica das conexinas 43, 26 e 32 em relação à expressão da $\beta$-actina. A expressão de $\beta$-actina apresentou uniformidade, indicando que havia a mesma quantidade inicial de proteínas em todas as amostras $(n=6 /$ genótipo $)$ 

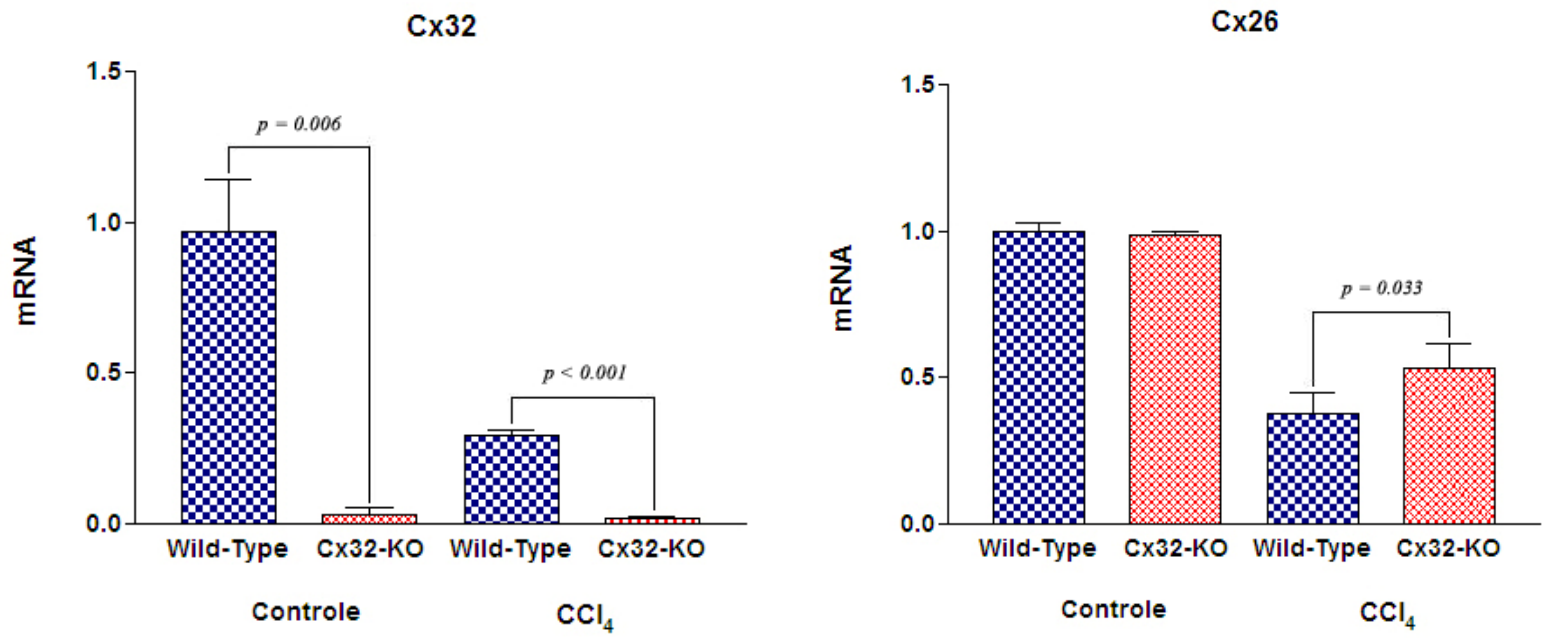

Cx43

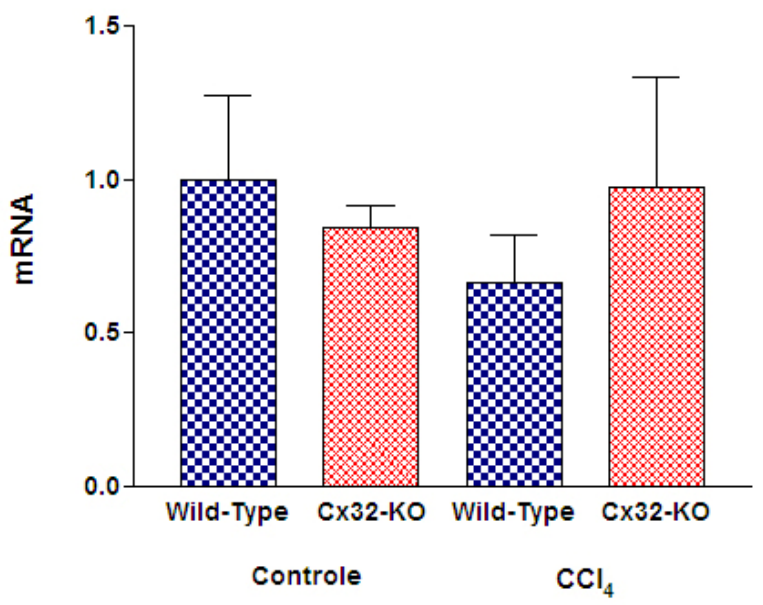

Figura 39 - Expressão gênica relativa das conexinas 43, 32 e 26 no fígado de animais controle e fibróticos de ambos os genótipos ( $\mathrm{n}=6 /$ genótipo). Assim como no western blot, não houve diferença estatística na expressão gênica da $\mathrm{Cx} 43$ entre os diferentes genótipos $(p<0,05)$

A avaliação funcional da comunicação intercelular pela técnica de incisão e transferência de lucifer yellow (cut-end) foi realizada no tecido hepático dos animais controles e fibróticos, em ambos os genótipos. Não houve diferença na difusão do corante entre os animais wild-type controles ou fibróticos. No entanto, os animais $\mathrm{Cx} 32-\mathrm{KO}$ fibróticos apresentaram menor área de difusão do corante no tecido hepático, com redução de 32,3\% em comparação aos camundongos wild-type fibróticos, indicando menor capacidade de comunicação por junções do tipo gap nestes animais (Figuras 40 e 41). 


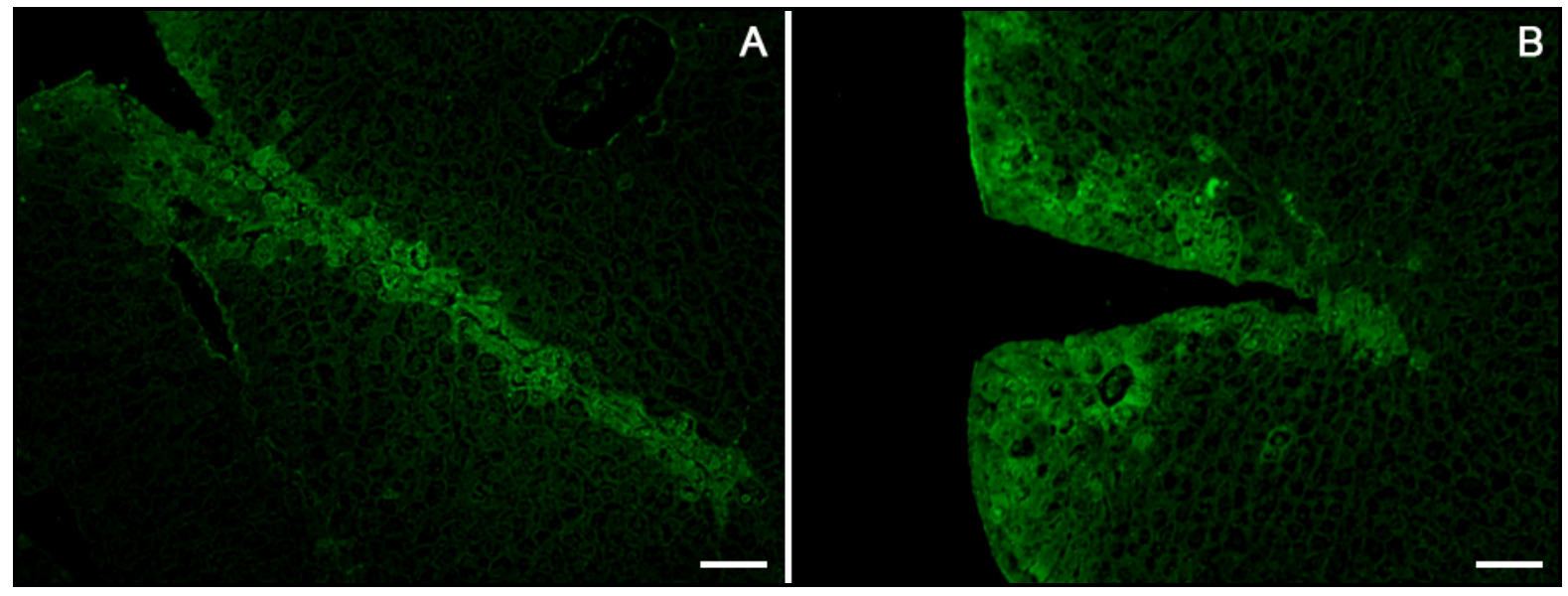

Figura 40 - Avaliação funcional da comunicação intercelular pela técnica de incisão e transferência de lucifer yellow (cut-end). (A) Tecido hepático de animal Cx32KO. Barra de escala $=50 \mu \mathrm{m}$. (B) Tecido hepático de animal WT. Barra de escala $=10 \mu \mathrm{m}$. Observe que os animais wild-type apresentaram uma maior área de difusão do corante LY ao redor do corte no tecido hepático $(\mathrm{n}=10 /$ genótipo $)$

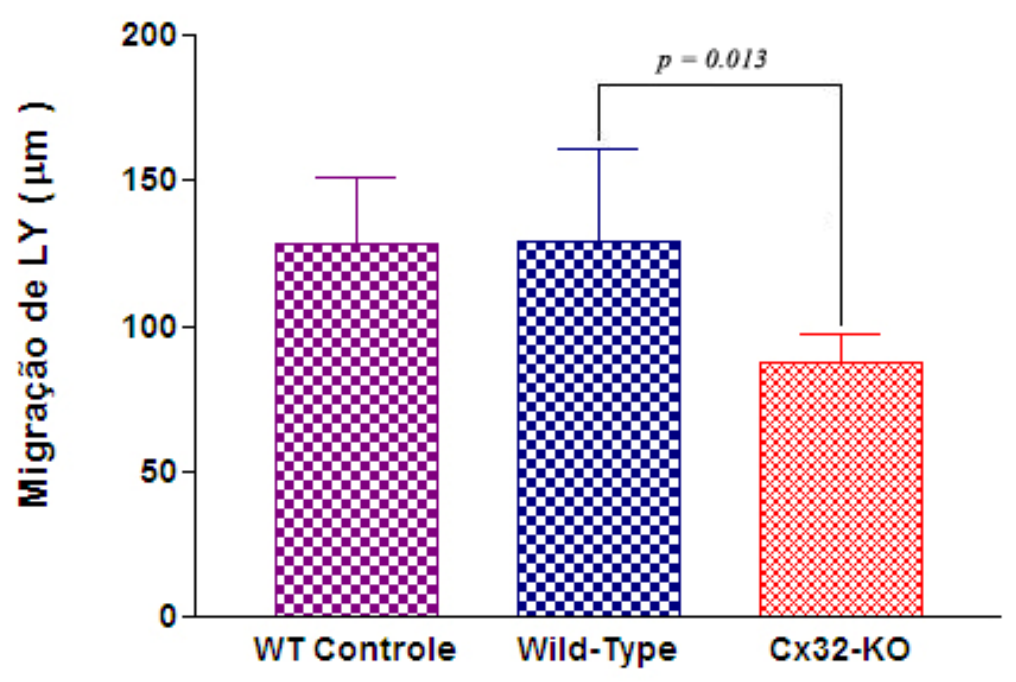

Figura 41 - Difusão do corante lucifer yellow no tecido hepático para avaliação funcional da comunicação intercelular ( $\mathrm{n}=10$ /genótipo). Os animais $\mathrm{Cx} 32-\mathrm{KO}$ fibróticos apresentaram redução de $32,3 \%$ na migração do corante $L Y$, representando uma menor funcionalidade das junções comunicantes do tipo gap nestes animais $(p=0,013)$ 


\section{DISCUSSÃO}

Pela primeira vez, a função das conexinas 43 ou 32 foi avaliada no microambiente da fibrose hepática em camundongos geneticamente modificados. Os resultados demonstraram que tanto os animais deficientes em $\mathrm{Cx} 43\left(\mathrm{Cx} 43^{+/}\right)$como os animais knockouts para $\mathrm{Cx} 32$ $\left(\mathrm{C} 32^{-/-}\right)$apresentaram exacerbação da fibrose hepática após indução da injúria crônica pelo tetracloreto de carbono. Entretanto, o aumento na deposição de colágeno no parênquima hepático, observado em cada modelo animal, foi aparentemente desencadeado por diferentes mecanismos. Os resultados obtidos neste trabalho demonstraram a importante participação das conexinas 43 ou 32 no controle da fibrose hepática e de outros mecanismos celulares. Por fim, compreender a função das conexinas no processo de fibrogênese pode revelar novas ferramentas no controle e tratamento da fibrose hepática.

A primeira análise realizada foi em relação aos parâmetros biométricos, onde foram comparados o peso do fígado e os índices hepáticos relacionados ao peso vivo e corpóreo dos animais deficientes em $\mathrm{Cx} 43$ ou 32. Os dados obtidos indicaram que não houve diferença entre os genótipos nos grupos dos animais controles ou fibróticos, em ambos o modelos animais. Por outro lado, os animais com fibrose apresentaram índices hepáticos elevados em relação aos animais controle, indicando um esperado aumento de peso do fígado pela deposição de colágeno. A análise dos aspectos macroscópicos demonstrou que o fígado fibrótico dos animais deficientes em $\mathrm{Cx} 43$ apresenta características mais acentuadas do que os animais wild-type (WT) com fibrose. Ou seja, estes animais apresentaram um processo de micronodulação superficial mais acentuado, com comprometimento dos bordos e retração da cápsula hepática mais grave. Estes achados também foram comprovados pela microscopia eletrônica de varredura, evidenciando uma maior nodulação na superfície hepática dos animais $\mathrm{Cx} 43^{+/-}$. Nos animais deficientes em $\mathrm{Cx} 32$, não foram observadas diferenças significativas no padrão macroscópico das lesões superficiais entre os diferentes genótipos dos animais fibróticos.

O estadiamento comparativo da fibrose foi realizado em lâminas coradas pela técnica de picrossírius e analisada segundo os critérios modificados por Ishak et al. (1995). Os resultados não demonstraram diferença significativa no estadiamento da fibrose hepática entre os genótipos no grupo dos animais fibróticos, em ambos os modelos animais. No entanto, esta avaliação é qualitativa e leva em consideração apenas o padrão de distribuição do colágeno no parênquima hepático. Apesar de não haver diferença no grau de fibrose entre os genótipos, foi 
possível observar uma diferença visual na proporção volumétrica ocupada pelo colágeno no tecido hepático dos animais deficientes em Cx43 ou Cx32 fibróticos. Sendo assim, foi utilizado um método semi-quantitativo para estimar o volume ocupado pelo colágeno a partir da mensuração de sua área em microscopia de luz, baseado no princípio de Delesse. M.A. Delesse foi um geologista francês que, em 1842, constatou que a fração volumétrica de minerais poderia ser estimada através da área média na superfície de rochas. Fundamentado em provas matemáticas, este princípio corrobora com a hipótese de que a área média de diversas regiões é um método confiável de estimação do volume de estruturas em secções histológicas (WEIBEL, 1989). Dessa maneira, nossa percepção visual foi comprovada pela morfometria das fibras colágenas coradas pelo picrossírius, onde se detectou aumento de $66,8 \%$ na proporção volumétrica de colágeno nos animais $\mathrm{Cx} 43^{+/-}$e aumento de $23,7 \%$ nos animais $\mathrm{Cx} 32^{-/-}$. Este aumento na proporção volumétrica também foi observado após a imunomarcação das fibras colágenas tipo I, demonstrando maior densidade do colágeno nas pontes fibrosas entre e ao redor dos espaços vasculares. Estes dados demonstraram que os animais deficientes em $\mathrm{Cx} 43$ ou 32 apresentaram maior quantidade de matriz extracelular no fígado durante o processo fibrogênico induzido pelo $\mathrm{CCl}_{4}$.

Outros trabalhos apresentaram resultados interessantes em relação à influência da expressão das conexinas no processo fibrogênico, com resultados semelhantes aos demonstrados neste modelo de fibrose hepática. Os fibroblastos apresentam abundante expressão de Cx43 (EHRLICH; DIEZ, 2003) e possuem expressão diferencial na epiderme durante o desenvolvimento, reparação e doenças teciduais (MAHER et al., 2005). Kretz et al. (2003) demonstraram que camundongos deficientes em conexina 43 apresentam fechamento precoce da ferida cutânea. Por sua vez, Mori et al. (2006) mostraram que camundongos tratados topicamente com terapia antisense para $\mathrm{Cx} 43$ apresentam aceleração na reparação tecidual, aumento na proliferação de queratinócitos e migração de fibroblastos na ferida, assim como aumento na deposição de matriz colágena. Estes autores também observaram decréscimo na infiltração de neutrófilos e redução do recrutamento de macrófagos, proporcionando uma significativa melhora na reparação tecidual devido à diminuição da expressão da conexina 43 .

Lu et al. (2007) demonstraram que fibroblastos provenientes de cicatrizes quelóides ou hipertróficas apresentaram quantidade muito menor de $\mathrm{Cx} 43$ em relação a fibroblastos oriundos de pele normal. Abdullah et al. (1999) avaliaram fibroblastos de pacientes diabéticos e constataram uma menor funcionalidade da comunicação intercelular, corroborando com a maior dificuldade de cicatrização presente em indivíduos diabéticos. Oloris et al. (2007) 
avaliaram o desenvolvimento de granulomas hepáticos, induzidos por Schistosoma mansoni, em camundongos deficientes em $\mathrm{Cx} 43$. Os autores demonstraram maior deposição de fibras colágenas ao redor dos granulomas hepáticos nos animais $\mathrm{Cx} 43^{+/}$. Estes estudos demonstraram que a expressão da conexina 43 está diretamente envolvida nos mecanismos de reparação tecidual e deposição de colágeno, independentemente do tecido analisado, como na pele ou no próprio fígado.

Em relação à expressão de $\mathrm{Cx} 32$, apenas um trabalho realizado com tenócitos in vitro (fibroblastos presentes nos tendões) demonstrou que a diminuição de Cx32 por terapia antisense ocasiona aumento na deposição de colágeno, independentemente do estímulo mecânico (WAGGETT; BENJAMIN; RALPHS, 2006). No fígado, as células responsáveis pela síntese de colágeno não expressam $\mathrm{Cx} 32$, mas sofrem influências de fatores de crescimento e citocinas liberadas pelos hepatócitos, por exemplo, que expressam esta conexina. Sendo assim, os resultados aqui apresentados sugerem a presença de mecanismos diferentes na ativação da fibrogênese hepática entre os animais deficientes em Cx43 ou 32.

A análise por microscopia eletrônica de transmissão possibilitou a observação de intensa deposição de fibras colágenas, dispostas em diversas direções, ao redor de células com características morfológicas de miofibroblastos no tecido hepático de animais fibróticos. Analisando criteriosamente as fibras de colágeno em cortes transversais, foi possível observar fibras mais espessas e com morfologia irregular nos animais deficientes em $\mathrm{Cx} 43$. Estes achados foram semelhantes aos descritos por Carbone et al. (2006), onde os autores avaliaram a morfologia ultra-estrutural das fibras colágenas presentes na região da decídua em camundongos. Nesta região, foram descritas fibras colágenas irregulares e espessas, ocasionadas pela agregação lateral de outros tipos de colágenos a uma fibrila central. Da mesma forma, as fibrilas presentes na fibrose hepática apresentaram esta característica, a qual pode estar relacionada a um processo adaptativo da matriz extracelular ao novo ambiente bioquímico e estrutural hepático. Ou ainda pode ser resultante da diminuição da comunicação intercelular das células produtoras de colágeno no fígado, que expressam $\mathrm{Cx} 43$ quando ativadas.

Devido aos resultados obtidos em relação à fibrose hepática, foram avaliados os principais genes envolvidos na produção e degradação da matriz extracelular, na expectativa de elucidar quais mecanismos estão ativados ou suprimidos nos animais deficientes em Cx43 ou 32, que levaram ao aumento da fibrose hepática observado neste modelo experimental.

Resumidamente, no processo de fibrogênese o estroma deve ser remodelado por meio de lise da antiga matriz extracelular e síntese de uma nova matriz (MANGNALL et al., 2003). 
Esta lise ocorre mediante ativação das metaloproteinases (MMP), as quais são reguladas por inibidores teciduais das metaloproteinases (TIMPs), sendo que o desequilíbrio entre estes mecanismos produz uma excessiva deposição de colágeno nas doenças hepáticas crônicas (PROSSER; YEN; WU, 2006). As células estreladas hepáticas, quando ativadas em miofibroblastos, são as principais células envolvidas na deposição de colágeno, sendo também responsáveis pela produção de diversas citocinas e fatores de crescimento que regulam positiva ou negativamente a fibrogênese hepática (FRIEDMAN, 2008a). Os miofibroblastos expressam a proteína de citoesqueleto alfa-actina de músculo liso ( $\alpha$-SMA), sendo considerada um marcador de sua atividade e, conseqüentemente, de sua capacidade proliferativa e pró-fibrogênica (NOVO et al., 2009). Durante a fibrogênese, as células estreladas ativadas são estimuladas pelo potente fator pró-fibrogênico TGF $\beta$-1, produzindo colágenos tipo I e III, além de outros componentes da MEC (LI; FRIEDMAN, 2003; FRIEDMAN, 2008b).

Os resultados apresentados pela análise da expressão gênica foram muito interessantes e sugerem os possíveis mecanismos presentes nos animais deficientes em conexina 43. Os animais com fibrose hepática de ambos os genótipos apresentaram aumento na expressão gênica de $\alpha$-SMA em relação aos animais controle, indicando que as células estreladas foram ativadas em miofibroblastos e, conseqüentemente, produziram colágeno. No entanto, quando os genótipos fibróticos foram comparados entre si, não foram observadas diferenças entre a expressão gênica da $\alpha$-SMA. Este resultado sugere que a diminuição da Cx43 não exerce um efeito importante no processo de ativação das HSCs em miofibroblastos. A análise transcricional do colágeno tipo I demonstrou grande aumento em sua expressão no animais com fibrose hepática em relação aos animais controles, como esperado. No entanto, a expressão deste gene foi menor nos animais $\mathrm{Cx} 43^{+/-}$fibróticos em relação aos animais WT fibróticos. A expressão gênica do TGF $\beta-1$, principal fator pró-fibrogênico, apresentou comportamento semelhante em relação ao seu gene alvo. Estes resultados da expressão gênica contradizem todos os aspectos macro e microscópicos observados no tecido fibrótico dos animais deficientes em $\mathrm{Cx} 43$. Por outro lado, a análise dos genes responsáveis pela degradação da matriz extracelular auxiliou na compreensão dos mecanismos de fibrogênese presente nestes animais, pois estes genes também apresentaram redução em sua expressão.

A expressão gênica das metaloproteinases 2 e 13 (MMPs-2 e -13), assim como do inibidor tecidual de metaloproteinases 1 (TIMP-1) foi maior nos animais fibróticos em relação aos animais controles. No entanto, os animais $\mathrm{Cx} 43^{+/-}$fibróticos apresentaram menor 
expressão desses genes quando comparados aos animais WT fibróticos. A MMP-13 é considerada a principal colagenase presente em roedores e é responsável, principalmente, pela degradação dos colágenos intersticiais tipo I e III. A MMP-2, além de capacidade proteolítica em gelatinas e colágeno IV, também degrada colágeno tipo I (VARGAS; BRENNER; PHAN, 2005). Sendo assim, é possível inferir que os animais deficientes em Cx43 apresentaram maior quantidade de colágeno no tecido hepático devido à menor capacidade de degradação do colágeno depositado pela ação proteolítica das metaloproteinases.

A expressão de TIMP-1 está elevada nos animais fibróticos de ambos os genótipos quando comparado com seus respectivos controles, indicando que a fibrose está em seu período ativo e com grande inibição das MMPs. No entanto, mais uma vez os animais $\mathrm{Cx} 43^{+/-}$ fibróticos apresentaram menor expressão de TIMP-1 em relação aos animais WT fibróticos. As células estreladas são as principais responsáveis pela produção das MMPs e TIMPs, além do colágeno tipo I e TGF $\beta$-1 (FRIEDMAN, 2008c). Sendo assim, é possível sugerir que a deficiência da Cx43 esteja afetando a capacidade funcional das HSCs ativadas em miofibroblastos, apesar de não ter afetado o processo de ativação celular. No entanto, são necessárias análises complementares da expressão protéica e atividade enzimática destas moléculas para definir melhor o padrão de alteração funcional.

Diferentemente dos animais deficientes em Cx43, os animais deficientes em Cx32 fibróticos apresentaram maior expressão gênica do colágeno tipo I em relação aos animais WT, corroborando os dados da morfometria e imunofluorescência do colágeno tipo I. Adicionalmente, não houve diferença na expressão gênica da MMP-2, indicando a presença de um mecanismo diferente na ativação da fibrogênese hepática nestes animais. Sendo assim, foram realizadas outras análises relacionadas à mensuração da atividade inflamatória tecidual e da função bioquímica hepática, além da capacidade de proliferação e apoptose nos hepatócitos.

Os efeitos tóxicos do tetracloreto de carbono $\left(\mathrm{CCl}_{4}\right)$ estão relacionados com sua biotransformação catalisada pela monoxigenase dependente do citocromo P-450, mais especificamente CYP2E1. Evidências comprovam que os danos hepáticos são mediados por processos de biotransformação de moléculas no retículo endoplasmático e mitocôndrias dos hepatócitos, oxidação de macromoléculas celulares por radicais livres e peroxidação lipídica Estes processos levam à perda das funções celulares e conseqüente morte dos hepatócitos afetados, promovendo diversas alterações bioquímicas e histológicas associadas à inflamação, necrose, fibrose e regeneração tecidual (VARGAS; BRENNER; PHAN, 2005). 
A análise histopatológica foi realizada segundo os critérios de atividade necroinflamatória modificados por Ishak et al. (1995). Nos animais deficientes em Cx43 fibróticos, foi observado aumento de $23 \%$ no índice de atividade histológica, indicando maior atividade das lesões necro-inflamatórias. Os animais deficientes em Cx32 também apresentaram aumento no índice de atividade histológica, sendo 20,4\% superior aos animais WT fibróticos. Corroborando a análise histopatológica, a função bioquímica hepática desses animais também apresentou alterações significativas. Nos animais $\mathrm{Cx} 43^{+/-}$fibróticos, houve aumento significativo nas enzimas hepáticas AST e ALT em relação aos animais WT fibróticos. Os animais $\mathrm{Cx} 32^{-/-}$fibróticos apresentaram aumento das enzimas hepáticas AST, ALT e fosfatase alcalina. De maneira geral, as enzimas aspartato aminotransferase (AST) e alanina aminotransferase (ALT) podem ser consideradas como indicadoras de danos hepáticos e o aumento de suas atividades enzimáticas séricas está relacionado à morte celular e extensão da lesão (SCHEFFER; GONZÁLEZ, 2005). Ou seja, a deficiência das Cx43 ou 32 afetou a homeostasia das células parenquimatosas, provocando maior atividade necro-inflamatória.

A conexina 32 é a principal proteína componente das junções do tipo gap no fígado e está localizada na membrana plasmática dos hepatócitos (STUTENKEMPER et al., 1992). Dessa maneira, possui grande importância na manutenção da homeostasia dos hepatócitos e sua deficiência pode acarretar sérios danos em suas funções básicas, como proliferação celular e apoptose. Diversos estudos demonstraram uma relação inversamente proporcional entre a comunicação intercelular e a proliferação celular em tumores (LOEWENSTEIN; KANNO, 1966; MESNIL, 2005). No entanto, esta correlação nem sempre se mostra fidedigna em todos os tipos celulares (KARDAMI et al., 2007) ou nos diferentes processos patológicos (DAGLI; HERNANDEZ-BLAZQUEZ, 2007). Alguns estudos realizados em animais com deficiência de Cx32 demonstraram maior susceptibilidade destes animais ao desenvolvimento de tumores hepáticos (TEMME et al., 1997; MA et al., 2000, 2002; OMORI et al., 2001; EVERT et al., 2002). No entanto, estes mesmos animais submetidos ao modelo da hepatectomia parcial apresentaram menor proliferação celular dos hepatócitos (TEMME et al., 2000). Resultados inversos aos identificados em neoplasias também foram descritos em animais deficientes em Cx43, com menor proliferação das células formadoras de granulomas hepáticos ou das células endoteliais no fígado submetido à colestase (OLORIS et al., 2007; TEIXEIRA et al., 2007).

Considerando todos os resultados controversos da literatura, foi realizada análise da proliferação dos hepatócitos pela marcação positiva para o antígeno nuclear de proliferação celular (PCNA). Foi observado que os animais deficientes em Cx32 apresentaram redução de $47,5 \%$ no número de hepatócitos em proliferação por $\mathrm{mm}^{2}$ de tecido hepático. Este resultado 
indica que a ausência da Cx32 influencia direta e negativamente na capacidade proliferativa dos hepatócitos, como demonstrando em processos não neoplásicos no fígado (TEMME et al., 1995; DAGLI et al., 2004). Interessantemente, a proliferação celular dos hepatócitos também foi menor nos animais deficientes em $\mathrm{Cx} 43$. Os animais $\mathrm{Cx} 43^{+/-}$fibróticos apresentaram redução de $71,8 \%$ no número de hepatócitos em proliferação por $\mathrm{mm}^{2}$ de tecido hepático. Nestes animais, a redução da proliferação dos hepatócitos pode estar relacionada à menor liberação e atuação do fator de crescimento dos hepatócitos (HGF). O HGF está presente agregado em moléculas da MEC, sendo liberado apenas quando ocorre degradação da matriz pelas MMPs. Como os animais $\mathrm{Cx} 43^{+/-}$fibróticos apresentaram menor degradação da matriz, conseqüentemente há uma menor liberação do HGF. Outra hipótese seria a excessiva deposição de colágeno e capilarização dos sinusóides, dificultado a passagem e absorção de substâncias hepatotróficas e nutrientes. No entanto, o envolvimento destes mecanismos ainda precisar ser elucidado e comprovado.

Complementarmente, a mensuração da apoptose dos hepatócitos foi analisada nos animais deficientes em Cx32 pela contagem dos corpúsculos apoptóticos nas lâminas coradas em HE e visualizadas sob microscopia de fluorescência. Esta metodologia baseia-se na propriedade da eosina, presente nos corpúsculos apoptóticos, fluorescer quando exposta a luz ultravioleta, sendo útil para identificar as fases finais da apoptose (WOOD; SARMA; ARCHER, 1999). Após a quantificação, foi demonstrado que os animais Cx32/- fibróticos apresentaram aumento de 40,3\% na quantidade de corpúsculos apoptóticos por $\mathrm{mm}^{2}$ de tecido hepático, representando uma maior taxa de apoptose quando comparado com os animais WT fibróticos. Estes resultados foram semelhantes ao descritos na literatura. Animais knockout para as conexinas 32 e 26 apresentaram aumento na incidência da apoptose em relação aos animais WT (OTT et al., 2006). Marx-Stoelting et al. (2008) submeteram camundongos knockout para as conexinas 26 ou 32 ao carcinógeno hepático N-Nitrosodietilamina e observaram aumento de apoptose apenas nos animais deficientes em Cx32. Analisando todos os resultados conjuntamente, percebe-se que os animais $\mathrm{C} \times 32^{-/-}$submetidos ao modelo de fibrose hepática pelo $\mathrm{CCl}_{4}$ apresentam redução no índice de proliferação celular e aumento da apoptose dos hepatócitos, assim como maior atividade necro-inflamatória no tecido hepático. Estas características podem ser responsáveis pela maior deposição de colágeno no fígado destes animais, representando um mecanismo de ativação da fibrogênese em resposta à injúria hepática, sem interferência da expressão gênica.

Como última análise, foi verificado o padrão de expressão das conexinas 32, 26 e 43 na fibrose hepática em ambos os modelos animais. Nos animais $\mathrm{Cx} 43^{+/-}$, as expressões 
protéica e gênica das Cx32 e Cx26 não apresentaram diferença entre os animais controles e fibróticos de ambos os genótipos, sugerindo que não existe uma significativa modulação destas proteínas no modelo de fibrose hepática. Em relação à expressão da $\mathrm{Cx} 43$, foi demonstrado que os animais $\mathrm{Cx} 43^{+/-}$controles apresentam redução de $45 \%$ em sua expressão quando comparados aos animais WT controles, resultado óbvio e já esperado, uma vez que os camundongos sofreram a remoção de um dos genes alelos, apresentando em seu genótipo metade da expressão dessa proteína. Os animais $\mathrm{Cx} 43^{+/-}$fibróticos apresentaram aumento das células Cx43-positivas nos espaços perissinusoidais quando comparados aos animais WT fibróticos. Porém, a maior parte da imunoreatividade observada ocorreu no citoplasma das células perissinusoidais, indicando a localização aberrante da $\mathrm{Cx} 43$. A regulação das junções do tipo gap pode ocorre nos níveis transcricional, translacional e pós-translacional, sendo ainda necessário o transporte correto para a membrana, formando placas funcionais (YAMASAKI; NAUS, 1996). González et al. (2002) comprovaram que o aumento transitório da expressão de conexina 43 no fígado de ratos submetidos a diferentes modelos colestáticos ocorre devido ao aumento do número de células de Kupffer infiltradas nos espaços perissinusoidais. Estas células expressam conexina 43 quando estão ativadas, assim como as células estreladas hepáticas (FISCHER et al., 2005; EUGENÍN et al., 2007). Assim, estes resultados indicam que, apesar da maior quantidade de $\mathrm{Cx} 43$ no fígado fibrótico, a formação de junções comunicantes funcionais pode estar comprometida devido à localização aberrante desta proteína. Este aumento na expressão de $\mathrm{Cx} 43$ pode estar relacionado à proliferação de células estreladas ou de Kupffer nos espaços perissinusoidais.

No modelo dos animais $\mathrm{Cx} 32^{-/-}$, os resultados relacionados com a expressão das conexinas estavam dentro do esperado (TEMME et al., 1997). Os animais knockout apresentaram expressão nula da $\mathrm{Cx} 32$, tanto nos animais controle como nos animais fibróticos em todas as técnicas analisadas: imunofluorescência, western blot e PCR em tempo real. Normalmente, os animais knockout para Cx32 também apresentam uma expressão consideravelmente reduzida de Cx26, provavelmente devido à co-localização destas proteínas na membrana dos hepatócitos (TEMME et al., 1997). Da mesma forma, os animais knockout controles e fibróticos apresentaram diminuição da expressão de Cx26 pelas técnicas de imunofluorescência e western blot. Porém os resultados da expressão gênica por PCR em tempo real foram contraditórios nos animais knockout, provavelmente devido a uma mudança pós-transcricional que causa diminuição da síntese protéica, ou a um transtorno nos controles pós-translacionais. 
Analisando apenas as diferenças entre os animais dos grupos controle e fibrótico do mesmo genótipo, foi possível observar redução nas conexinas 32 e 26 devido ao desenvolvimento da fibrose hepática induzida pelo $\mathrm{CCl}_{4}$. Muitos autores descrevem a redução das Cx32 e 26 nas doenças hepáticas crônicas em humanos (YAMAOKA et al., 1995, 2000; NAKASHIMA et al., 2004) e em modelos experimentais (NAKATA et al., 1996; RODRIGUES et al., 2009). Diferentemente dos animais deficientes em Cx43, os animais knockout para Cx32 não apresentaram participação da $\mathrm{Cx} 43$ no processo de fibrogênese desses animais. Assim, todas as técnicas aqui demonstradas não apresentaram diferenças significantes na expressão gênica ou protéica da conexina 43.

A avaliação funcional da comunicação intercelular pela técnica de incisão e transferência de lucifer yellow (cut-end) demonstrou que os animais Cx32/- apresentaram redução de $32,3 \%$ na taxa de migração do corante pelo tecido hepático em comparação com os animais WT, indicando redução na funcionalidade dos canais comunicantes devido ausência da $\mathrm{Cx} 32$ e redução da $\mathrm{Cx} 26$. No entanto, entre os animais controles e fibróticos do mesmo genótipo não houve alteração na funcionalidade dos canais, sugerindo ausência de distúrbio de comunicação intercelular devido o processo da doença hepática crônica, apesar da redução na expressão gênica das conexinas. Apesar de serem encontrados na literatura alguns estudos sobre a expressão das conexinas nas doenças hepáticas crônicas, nenhum trabalho avaliou a funcionalidade dos canais comunicantes.

Os resultados obtidos neste estudo permitiram a elaboração de algumas propostas de possíveis modos de ação exercidos pela deficiência das conexinas 43 ou 32 no desenvolvimento da fibrose hepática. Estes mecanismos sugeridos podem ser visualizados nas figuras 42 e 43. 


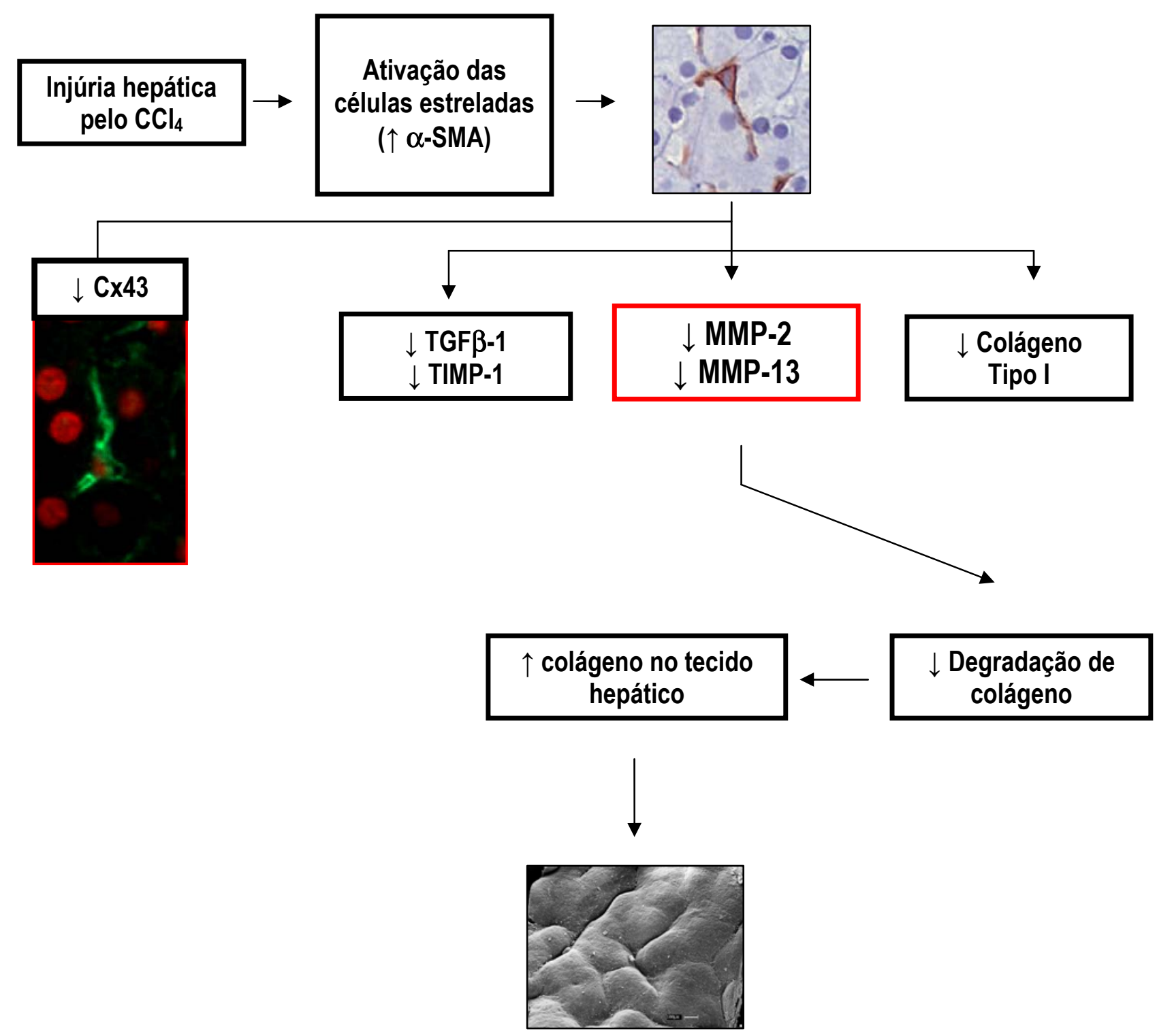

Figura 42 - Proposta de modo de ação exercido pela deficiência da Cx43 na fibrogênese hepática em camundongos submetidos ao modelo de fibrose pelo tetracloreto de carbono. Após injúria celular pelo $\mathrm{CCl}_{4}$, ocorre ativação das células estreladas hepáticas em miofibroblastos, os quais expressam $\alpha$-SMA. Não há diferença na ativação celular entre os genótipos dos animais fibróticos, no entanto, a deficiência de $\mathrm{Cx} 43$ promove menor funcionalidade das HSCs devido redução na expressão gênica de MMP-2, MMP-13, TIMP-1, TGFb-1 e colágeno tipo I. Dessa maneira, com especial importância na redução da degradação da MEC pelas MMPs, ocorre acúmulo de colágeno no tecido hepático, visualizado em todas as técnicas macro e microscópicas descritas nos resultados deste trabalho 

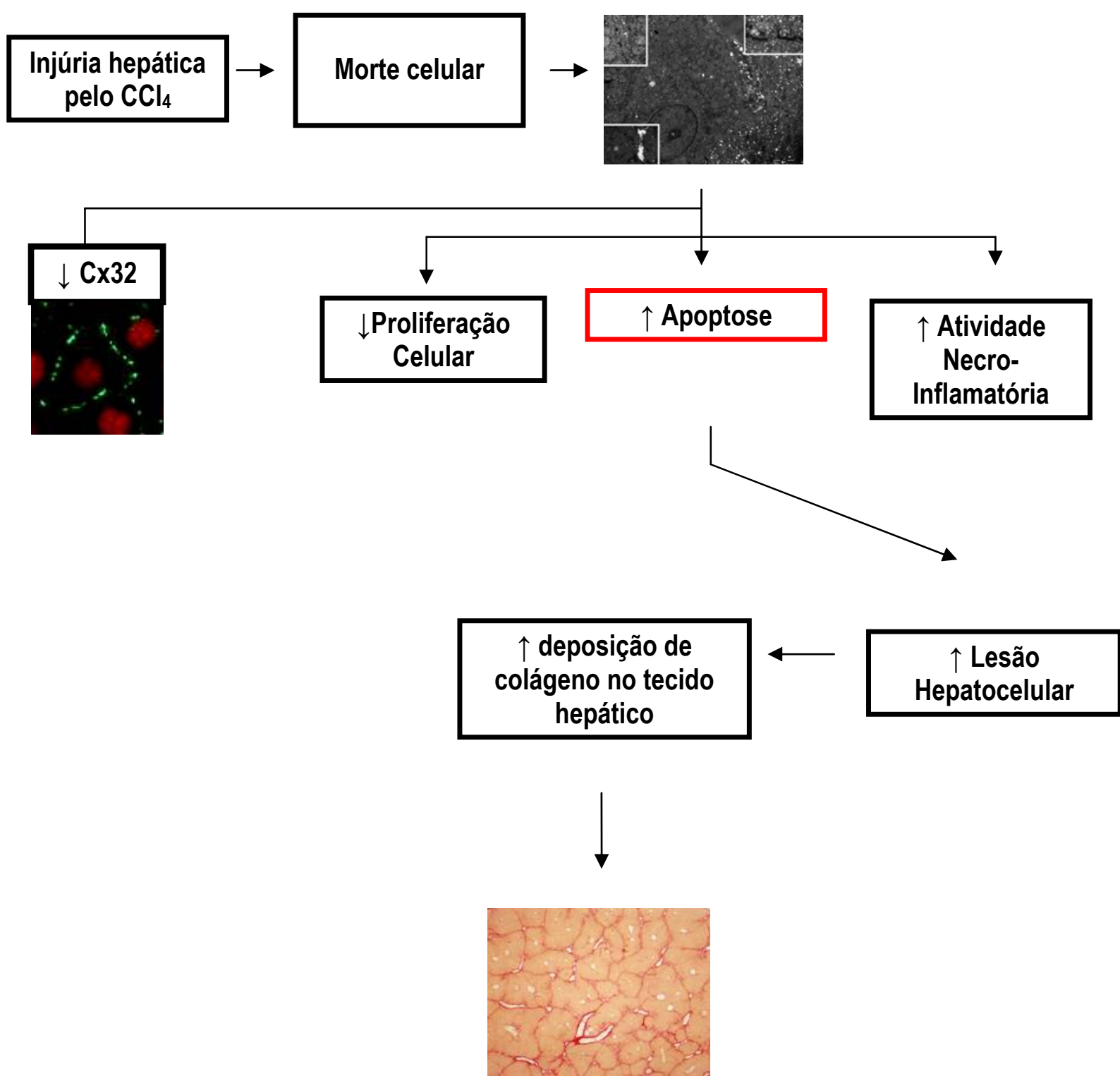

Figura 43 - Proposta de modo de ação exercido pela deficiência da Cx32 na fibrogênese hepática em camundongos submetidos ao modelo de fibrose pelo tetracloreto de carbono. Após injúria celular pelo $\mathrm{CCl}_{4}$, ocorre morte celular e aumento da atividade necro-inflamatória tecidual. Com a redução na expressão de Cx32, os hepatócitos apresentam redução na proliferação celular e aumento da taxa de apoptose. Assim, o maior grau de lesões necro-inflamatórias, aliado a um desequilíbrio entre as taxas de proliferação celular e apoptose, promove uma maior deposição de colágeno em resposta ao aumento das lesões hepatocelulares 
Baseando-se em todos os resultados obtidos, pode-se inferir que os animais deficientes em Cx43 apresentaram uma maior quantidade de colágeno no fígado devido sua menor capacidade de degradação da MEC. E não pela maior produção e deposição de colágeno. $\mathrm{Na}$ verdade, observou-se que todas as moléculas produzidas pelas HSCs ativadas em miofibroblastos apresentaram-se diminuídas. Estes dados podem indicam que, mesmo não havendo alterações no processo de ativação celular, as células estreladas apresentaram diminuição em sua funcionalidade (Figura 42). Por sua vez, o modelo de fibrose hepática nos animais deficientes em Cx32 demonstrou que as alterações morfológicas e funcionais estão relacionadas de maneira direta com os hepatócitos, que são as células que expressam conexina 32 no fígado. Assim, o maior grau de lesões necro-inflamatórias, aliado a um desequilíbrio entre as taxas de proliferação celular e apoptose, promove uma maior deposição de colágeno em resposta à injúria celular mais acentuada (Figura 43).

Estes resultados sugerem uma importante participação das conexinas 43 e 32 no processo de fibrogênese hepática, aparentemente ocasionada por diferentes mecanismos. Neste contexto, estas proteínas tornam-se potenciais moléculas-alvo no desenvolvimento de terapias anti-fibróticas. Como por exemplo, a aplicação de terapias gênicas poderia auxiliar na modulação positiva destas conexinas, melhorando a comunicação intercelular nas células alvo e, talvez, auxiliando na redução do colágeno no fígado fibrótico. 


\section{CONCLUSÕES}

7.1 As Cx43 ou Cx32 exercem influências opostas na atividade das lesões necroinflamatórias após injúria hepática crônica pelo $\mathrm{CCl}_{4}$, com alteração correspondente na função bioquímica.

7.2 A Cx32 apresenta participação direta no controle da proliferação e apoptose dos hepatócitos, após lesão crônica por $\mathrm{CCl}_{4}$, por vias não elucidadas.

7.3 A Cx43 influencia indiretamente a proliferação dos hepatócitos após lesão crônica por $\mathrm{CCl}_{4}$, por mecanismos ainda desconhecidos.

7.4 A Cx32 atua indiretamente na fibrose hepática, a qual apenas reflete um ambiente com maior atividade inflamatória associada ao desequilíbrio entre proliferação e apoptose dos hepatócitos.

7.5 A Cx43 influencia diretamente na fibrose hepática, provavelmente alterando a função das células responsáveis pela degradação da matriz extracelular.

7.6 A fibrose hepática não influencia a expressão das conexinas ou a capacidade de comunicação intercelular no fígado, com exceção da localização aberrante da Cx43 no citoplasma de células perissinusoidais presentes nos animais deficientes em $\mathrm{Cx} 43$. 


\section{REFERÊNCIAS}

ABDULLAH, K. M.; LUTHRA, G.; BILSKI, J. J.; ABDULLAH, S. A.; REYNOLDS, L. P.; REDMER, D. A.; GRAZUL-BILSKA, A. T. Cell-to-cell communication and expression of gap junctional proteins in human diabetic and nondiabetic skin fibroblasts: effects of basic fibroblast growth factor. Endocrine, v. 10, n. 1, p. 35-41, 1999.

ALBRIGHT, C. D.; KUO, J.; JEONG, S. cAMP enhances Cx43 gap junction formation and function and reverses choline deficiency apoptosis. Experimental and Molecular Pathology, v. 71, n. 1, p. 34-39, 2001.

ARTHUR, M. J. Fibrogenesis II: Metalloproteinases and their inhibitors in liver fibrosis. American Journal of Physiology: Gastrointestinal and Liver Physiology, v. 279, n. 2, p. G245-249, 2000.

ASAZUMA-NAKAMURA, Y.; DAI, P.; HARADA, Y.; JIANG, Y.; HAMAOKA, K.; TAKAMATSU, T. Cx43 contributes to TGF-beta signaling to regulate differentiation of cardiac fibroblasts into myofibroblasts. Experimental Cell Research, v. 315, n. 7, p. 11901199, 2009.

BAJPAI, S.; SHUKLA, V. K.; TRIPATHI, K.; SRIKRISHNA, S.; SINGH, R. K. Targeting connexin 43 in diabetic wound healing: future perspectives. Journal of Postgraduate Medicine, v. 55, n. 2, p. 143-149, 2009.

BATALLER, R.; BRENNER, D. A. Hepatic stellate cells as a target for the treatment of liver fibrosis. Seminars in Liver Disease, v. 21, p. 437-451, 2001.

BEDOSSA, P.; PARADIS, V. Liver extracellular matrix in health and disease. Journal of Pathology, v. 200, n. 4, p. 504-515, 2003.

BEYER, E. C.; PAUL, D. L.; GOODENOUGH, D. A. Connexin43: a protein from rat heart homologous to a gap junction protein from liver. The Journal of Cell Biology, v. 105, p. 2621-2629, 1987.

BODE, H. P.; WANG, L.; CASSIO, D.; LEITE, M. F.; ST-PIERRE, M. V.; HIRATA, K.; OKAZAKI, K.; SEARS, M. L.; MEDA, P.; NATHANSON, M. H.; DUFOUR, J. F. Expression and regulation of gap junctions in rat cholangiocytes. Hepatology, v. 36, n. 3, p. 631-640, 2002. 
BOISCLAIR, J.; DORÉ, M.; BEAUCHAMP, L.; CHOUINARD, L.; GIRARD, C. Characterization of the inflammatory infiltrate in canine chronic hepatitis. Veterinary Pathology, v. 38, n. 6, p. 628-635, 2001.

BRUZZONE, R.; WHITE, T. W.; PAUL, D. L. Connections with connexins: the molecular basis of direct intercellular signaling. European Journal of Biochemistry, v. 238, n. 1, p. 127, 1996.

BRY, C.; MAASS, K.; MIYOSHI, K.; WILLECKE, K.; OTT, T.; ROBINSON, G. W.; HENNIGHAUSEN, L. Loss of connexin 26 in mammary epithelium during early but not during late pregnancy results in unscheduled apoptosis and impaired development.

Developmental Biology, v. 15, n. 267, p. 418-429, 2004.

CARBONE, K.; PINTO, N. M. P.; ABRAHAMSOHN, P. A.; ZORN, T. M. T. Arrangement and fine structure of collagen fibrils in the decidualized mouse endometrium. Microscopy Research and Technique, v. 69, p. 36-45, 2006.

CHAIBLE, L. M. Efeitos da deleção do gene Cx43 sobre o desenvolvimento fetal de camundongos de diferentes backgrounds genéticos: ênfase na osteogênese. 2008. 105 f. Dissertação (Mestrado em Ciências) - Faculdade de Medicina Veterinária e Zootecnia, Universidade de São Paulo, São Paulo, 2009.

CHANSON, M.; DEROUETTE, J. P.; ROTH, I.; FOGLIA, B.; SCERRI, I.; DUDEZ, T.; KWAK, B. R. Gap junctional communication in tissue inflammation and repair. Biochimica et Biophysica Acta, v. 1711, n. 2, p. 197-207, 2005.

CHARLES, J. A.; CULLEN, J. M.; VAN DEN INGH, T. S. G. A. M.; WINKLE, T. V.; DESMET, V. J. Morphological classification of neoplastic disorders of the canine and feline liver. In: Standards for clinical and histological diagnosis of canine and feline liver diseases. Philadelphia: WSAVA Liver Standardization Group, WB Saunders Co, 2006. p. 117-124.

CHEVILLE, N. F. Inflamation and Healing - Healing and Chronic Inflamation. In: Introduction to veterinary pathology, ed. EUA: Iowa State University Press. 1999. Pt 2, p. 136-138.

CHILTON, L.; GILES, W. R.; SMITH, G. L. Evidence of intercellular coupling between cocultured adult rabbit ventricular myocytes and myofibroblasts. The Journal of Physiology, v. 583, p. 225-236, 2007. 
COHEN-SALMON, M.; OTT, T.; MICHEL, V.; HARDELIN, J. P.; PERFETTINI, I.; EYBALIN, M.; WU, T.; MARCUS, D. C.; WANGEMANN, P.; WILLECKE, K.; PETIT, C. Targeted ablation of connexin26 in the inner ear epithelial gap junction network causes hearing impairment and cell death. Current Biology, v. 9, n. 12, p. 1106-1111, 2002.

CONSOLO, M.; AMOROSO, A.; SPANDIDOS, D. A.; MAZZARINO, M. C. Matrix metalloproteinases and their inhibitors as markers of inflammation and fibrosis in chronic liver disease. International Journal of Molecular Medicine, v. 24, n. 2, p. 143-152, 2009.

COUTINHO, P.; QIU, C.; FRANK, S.; WANG, C. M.; BROWN, T.; GREEN, C. R.; BECKER, D. L. Limiting burn extension by transient inhibition of Connexin 43 expression at the site of injury. British Journal of Plastic Surgery. v. 58, p. 658-67, 2005.

CRAWFORD, J. M. O fígado e o trato biliar. In: COTRAN, R. S.; KUMAR, V.; COLLINS, T. Patologia estrutural e functional. 6. ed. Rio de Janeiro: Guanabara Koogan, 2000. p. 759-808.

CULLEN, J. M.; MACLACHLAN, N. J. Liver, biliary system, and exocrine pancreas. In: MCGAVIN, M. D.; CARLTON, W. W.; ZACHARY, J. F. (Ed.). Thompson's special veterinary pathology. 3rd ed. St. Louis, MO: Mosby, 2001. p. 81-124.

CULLEN, J. M. Summary of the World Small Animal Veterinary Association standardization committee guide to classification of liver disease in dogs and cats. The Veterinary Clinics of North America: Small Animal Practice, v. 39, n. 3, p. 395-418, 2009.

DAGLI, M. L. Z.; YAMASAKI, H.; KRUTOVSKIKH, V.; OMORI, Y. Delayed liver regeneration and increased susceptibility to chemical hepatocarcinogenesis in transgenic mice expressing a dominant-negative mutant of connexin32 only in the liver. Carcinogenesis, v. 25, n. 4, p. 483-492, 2004.

DECROCK, E.; VINKEN, M.; DE VUYST, E.; KRYSKO, D. V.; D'HERDE, K.; VANHAECKE, T.; VANDENABEELE, P.; ROGIERS, V.; LEYBAERT, L. Connexinrelated signaling in cell death: to live or let die? Cell Death \& Differentiation, v. 16, n. 4, p. 524-36, 2009.

DE LEEUW, A. M.; MCCARTHY, S. P.; GEERTS, A.; KNOOK, D. L. Purified rat liver fatstoring cells in culture divide and contain collagen. Hepatology, v. 4, p. 392-403, 1984.

DERMIETZEL, R.; GAO, Y.; SCEMES, E.; VIEIRA, D.; URBAN, M.; KREMER, M.; BENNETT, M. V.; SPRAY, D. C. Connexin43 null mice reveal that astrocytes express multiple connexins. Brain Research: Brain Research Reviews, v. 32, p. 45-56, 2000. 
DI BONZO, V. L.; NOVO, E.; CANNITO, S.; BUSLETTA, C.; PATERNOSTRO, C.; POVERO, D.; PAROLA, M. Angiogenesis and liver fibrogenesis. Histology and Histopathology, v. 24, n. 10, p. 1323-1341, 2009.

DILL-MACKY, E. Chronic hepatitis in dogs. In: DIMSKI, D. S. The veterinary clinics of north america: small animal practice. Philadelphia: Saunders, 1995, v. 25, n. 2, p. 387-398.

DOBROWOLSKI, R.; WILLECKE, K. Connexin-caused genetic diseases and corresponding mouse models. Antioxidantes \& Redox Signaling, v. 11, n. 2, p. 283-295, 2009.

EDWARDS, G. O.; JONDHALE, S.; CHEN, T.; CHIPMAN, J. K. A quantitative inverse relationship between connexin 32 expression and cell proliferation in a rat hepatoma cell line. Toxicology, v. 253, n. 1-3, p. 46-52, 2008.

EHRLICH, H. P.; DIEZ, T. Role for Gap Junctional Intercellular Communications in Wound Repair. Wound Repair and Regeneration, v. 11, p. 481-489, 2003.

EUGENÍN, E. A.; GONZÁLEZ, H. E.; SÁNCHEZ, H. A.; BRAÑES, M. C.; SÁEZ, J. C. Inflammatory conditions induce gap junctional communication between rat Kupffer cells both in vivo and in vitro. Cell Immunology, v. 247, n. 2, p. 103-110, 2007.

EVERT, M.; OTT, T.; TEMME, A.; WILLECKE, K.; DOMBROWSKI, F. Morfology and morphometric investigation of hepatocellular preneoplastic lesions and neoplasms in connexin32-deficient mice. Carcinogenesis, v. 23, n. 5, p. 697-703, 2002.

FAVIER, R. P. Idiopathic hepatitis and cirrhosis in dogs. The Veterinary Clinics of North America: Small Animal Practice, v. 39, n. 3, p. 481-488, 2009.

FERNÁNDEZ, M.; SEMELA, D.; BRUIX, J.; COLLE, I.; PINZANI, M.; BOSCH, J. Angiogenesis in liver disease. Journal of Hepatology, v. 50, n. 3, p. 604-620, 2009.

FISCHER, R.; REINEHR, R.; LU, T. P.; SCHÖNICKE, A.; WARSKULAT, U.; DIENES, H. P.; HÄUSSINGER, D. Intercellular communication via gap junctions in activated rat hepatic stellate cells. Gastroenterology, v. 128, n. 2, p. 433-448, 2005.

FORBES, S. J.; RUSSO, F. P.; REY, V.; BURRA, P.; RUGGE, M.; WRIGHT, N. A.; ALISON, M. R. A significant proportion of myofibroblasts are of bone marrow origin in human liver fibrosis. Gastroenterology, v. 126, n. 4, p. 955-963, 2004. 
FRIEDMAN, S. L.; ROLL, F. J. Isolation and culture of hepatic lipocytes, Kupffer cells, and sinusoidal endothelial cells by density gradient centrifugation with Stractan. Analytical Biochemistry, v. 161, p. 201-218, 1987.

FRIEDMAN, S. L.; ROCKEY, D. C.; MCGUIRE, R. F.; MAHER, J. J.; BOYLES, J. K.; YAMASAKI, G. Isolated hepatic lipocytes and Kupffer cells from normal human liver: morphological and functional characteristics in primary culture. Hepatology, v. 15, p. 234243, 1992.

FRIEDMAN, S. L. Molecular regulation of hepatic fibrosis, an integrated cellular response to tissue injury. Journal of Biological Chemistry, v. 275, p. 2247-2250, 2000.

FRIEDMAN, S. L. Liver fibrosis-from bench to bedside. Journal of Hepatology, v. 38, p. 38-53, 2003.

FRIEDMAN, S. L. Mechanisms of hepatic fibrogenesis. Gastroenterology, v. 134, p. 16551669, 2008a.

FRIEDMAN, S. L. Hepatic stellate cells: protean, multifunctional, and enigmatic cells of the liver. Physiological Reviews, v. 88, n. 1, p. 125-172, 2008 b.

FRIEDMAN, S. L. Hepatic fibrosis -- overview. Toxicology, v. 254, n. 3, p. 120-129, 2008c.

FUJIMOTO, K.; NAGAFUCHI, A.; TSUKITA, S.; KURAOKA, A.; OHOKUMA, A.; SHIBATA, Y. Dynamics of connexins, E-cadherin and alpha-caterin on cell membranes during gap-junction formation. Journal of Cell Science, v. 110, p. 311-322, 1997.

GACA, M. D.; ZHOU, X.; ISSA, R.; KIRIELLA, K.; IREDALE, J. P.; BENYON, R. C. Basement membrane-likematrix inhibits proliferation and collagen synthesis by activated rat hepatic stellate cells: evidence formatrix-dependent deactivation of stellate cells. Matrix Biology, v. 22, p. 229-239, 2003.

GAYOTTO, L. C. C.; ALVES, V. A. F. Patologia das hepatites crônicas. In: GAYOTTO, L. C. C.; ALVES, V. A. F. Doenças do fígado e vias biliares. Rio de Janeiro: Atheneu, 2001. p. 553-564.

GAYOTTO, L. C. C. Lesões histológicas fundamentais. In: GAYOTTO, L. C. C.; ALVES, V. A. F. Doenças do fígado e vias biliares. Rio de Janeiro: Atheneu, 2001. p. 549-552. 
GIARDINA, S. F.; MIKAMI, M.; GOUBAEVA, F.; YANG, J. Connexin 43 confers resistance to hydrogen peroxide-mediated apoptosis. Biochemical Biophysical Research Communications, v. 26, n. 362(3), p. 747-52, 2007.

GONZÁlEZ, H. E.; EUGENÍN, E. A.; GARCÉS, G.; SOLIS, N.; PIZARRO, M.; ACCATINO, L.; SÁEZ, J. C. Regulation of hepatic connexins in cholestasis: possible involvement of Kupffer cells and inflammatory mediators. American Journal of Physiology: Gastrointestinal and Liver Physiology, v. 6, n. 282, p. 991-1001, 2002.

GOODENOUGH, D. A. Bulk isolation of mouse hepatocyte gap junctions. Characterization of the principal protein, connexin. Journal of Cell Biology, v. 61, p. 557-563, 1974.

GOODENOUGH, D. A.; GOLIGER, J. A.; PAUL, D. L. Connexins, connexons and intercellular communication. Annual Reviews on Biochemistry, v. 65, p. 475-502, 1996.

GRESSNER, A. M.; WEISKIRCHEN, R. Modern pathogenetic concepts of liver fibrosis suggest stellate cells and TGF-beta as major players and therapeutic targets. Journal of Cellular and Molecular Medicine, v. 1, n. 10, p. 76-99, 2006

GRESSNER, O. A.; GRESSNER, A. M. Connective tissue growth factor: a fibrogenic master switch in fibrotic liver diseases. Liver International, v. 28, n. 8, p. 1065-1079, 2008.

GREENWEL, P.; RUBIN, J.; SCHWARTZ, M.; HERTZBERG, E. L.; ROJKIND, M. Liver fat-storing cell clones obtained from a CCl4-cirrhotic rat are heterogeneous with regard to proliferation, expression of extracellular matrix components, interleukin-6, and connexin 43 . Laboratory Investigation, v. 69, p. 210-216, 1993.

GUERRA, J. L. Hepatocarcinogênese em camundongos portadores de deleção em um dos alelos da conexina $43\left(\mathrm{Cx}_{43}{ }^{+/}\right)$: estudos histomorfométricos. 2003. $86 \mathrm{f}$. Tese (Livre Docência) - Faculdade de Medicina Veterinária e Zootecnia, Universidade de São Paulo, São Paulo, 2003.

GUYOT, C.; LEPREUX, S.; COMBE, C.; DOUDNIKOFF, E.; BIOULAC-SAGE, P. ; BALABAUD, C. ; DESMOULIERE, A. Hepatic fibrosis and cirrhosis: The (myo)fibroblastic cell subpopulations involved. The International Journal of Biochemistry and Cell Biology, v. 38, n. 2, p. 135-151.

HAN, Y. P. Matrix metalloproteinases, the pros and cons, in liver fibrosis. Journal of Gastroenterology and Hepatology, v. 21, p. S88-91, 2006. Supplementum 3. 
HENNEMANN, H.; DAHL, E.; WHITE, J. B.; SCHWARZ, H. J.; LALLEY, P. A.; CHANG, S.; NICHOLSON, B. J.; WILLECKE, K. Two gap junction genes, connexin 31.1 and 30.3, are closely linked on mouse chromosome 4 and preferentially expressed in skin. The Journal of Biological Chemistry, v. 267, n. 24, p. 17225-17233, 1992.

HEMMANN, S.; GRAF, J.; RODERFELD, M.; ROEB, E. Expression of MMPs and TIMPs in liver fibrosis - a systematic review with special emphasis on anti-fibrotic strategies.

Journal of Hepatology, v. 46, n. 5, p. 955-975, 2007.

HIGAZI, A. A.; EL-HAJ, M.; MELHEM, A.; HORANI, A.; PAPPO, O.; ALVAREZ, C. E.; MUHANNA, N.; FRIEDMAN, S. L.; SAFADI, R. Immunomodulatory effects of plasminogen activators on hepatic fibrogenesis. Clinical \& Experimental Immunology, v. 152, n. 1, p. 163-173, 2008.

HOFFMANN, G. Copper-associated liver diseases. The Veterinary Clinics of North America: Small Animal Practice, v. 39, n. 3, p. 489-511, 2009.

HUTNIK, C. M.; POCRNICH, C. E.; LIU, H.; LAIRD, D. W.; SHAO, Q. The protective effect of functional connexin43 channels on a human epithelial cell line exposed to oxidative stress. Investigative Ophthalmology \& Visual Science, v. 49, n. 2, p. 800-806, 2008.

HWANG, J. W.; JUNG, J. W.; LEE, Y. S.; KANG, K. S. Indole-3-carbinol prevents $\mathrm{H}(2) \mathrm{O}(2)$-induced inhibition of gap junctional intercellular communication by inactivation of PKB/Akt. The Journal of Veterinary Medical Science, v. 70, n. 10, p. 1057-1063, 2008.

IIMURO, Y.; BRENNER, D. A. Matrix metalloproteinase gene delivery for liver fibrosis. Pharmaceutical Research, v. 25, n. 2, p. 249-258, 2008.

IOCONO, J. A.; KRUMMEL, T. M.; KEEFER, K. A.; ALLISON, G. M.; PAUL, H. Repeated additions of hyaluronan alters granulation tissue deposition in sponge implants in mice. Wound Repair and Regeneration, v. 6, p. 442-448, 1998.

IONTA, M.; FERREIRA, R. A.; PFISTER, S. C.; MACHADO-SANTELLI, G. M. Exogenous $\mathrm{Cx} 43$ expression decrease cell proliferation rate in rat hepatocarcinoma cells independently of functional gap junction. Cancer Cell International, v. 13, n. 9, p. 22, 2009.

IREDALE, J. P. Tissue inhibitors of metalloproteinases in liver fibrosis. The International Journal of Biochemistry and Cell Biology, v. 29, n. 1, p. 43-54, 1997. 
IREDALE, J. P.; BENYON, R. C.; PICKERING, J.; MCCULLEN, M.; NORTHROP, M.; PAWLEY, S.; HOVELL, C.; ARTHUR, M. J. Mechanisms of spontaneous resolution of rat liver fibrosis. Hepatic stellate cell apoptosis and reduced hepatic expression of metalloproteinase inhibitors. The Journal of Clinical Investigation, v. 102, p. 538-549, 1998.

IREDALE, J. P. Hepatic stellate cell behavior during resolution of liver injury. Seminars in Liver Disease, v. 21, p. 427-436, 2001.

IREDALE, J. P. Models of liver fibrosis: exploring the dynamic nature of inflammation and repair in a solid organ. The Journal of Clinical Investigation, v. 117, n. 3, p. 539-548, 2007.

ISHAK, K.; BAPTISTA, A.; BIANCHI, L.; CALLEA, F.; DE GROOTE, J.; GUDAT, F.; DENK, H.; DESMET, V.; KORB, G.; MACSWEEN, R. N.; PHILLIPS, M. J.;

PORTMANNL, B. G.; PAULSEN, H.; SCHEUER, P. J.; SCHMID, M.; THALER, H.

Histological grading and staging of chronic hepatitis. Journal of Hepatology. v. 22, n. 6. p. 696-699, 1995.

ISMAIL, M. H.; PINZANI, M. Reversal of liver fibrosis. Saudi Journal of Gastroenterology, v. 15, n. 1, p. 72-79, 2009.

JEONG, S. H.; HABEEBU, S. S.; KLAASSEN, C. D. Cadmium decreases gap junctional intercellular communication in mouse liver. Toxicological Sciences. v. 57, n. 1, p. 156-166, 2000 .

JUNQUEIRA, L. C.; BIGNOLAS, G.; BRENTANI, R. R. Picrosirius staining plus polarization microscopy, a specific method for collagen detection in tissue sections. The Histochemical Journal, v. 11, p. 447-455, 1979.

JUNQUEIRA, L. C.; CARNEIRO, J. Histologia básica. 10. ed. Rio de Janeiro: Guanabara Koogan, 2004.

KANCZUGA-KODA, L.; SULKOWSKI, S.; KODA, M.; SKRZYDLEWSKA, E.; SULKOWSKA, M. Connexin 26 correlates with Bcl-xL and Bax proteins expression in colorectal cancer. World Journal of Gastroenterology, v. 11, n. 10 , p. 1544-1548, 2005.

KARDAMI, E.; DANG, X.; IACOBAS, D. A.; NICKEL, B. E.; JEYARAMAN, M.; SRISAKULDEE, W.; MAKAZAN, J.; TANGUY, S.; SPRAY, D. C. The role of connexins in controlling cell growth and gene expression. Progress in Biophysics and Molecular Biology, v. 94, v. 1-2, p. 245-264, 2007. 
KING, T. J.; BERTRAM, J. S. Connexins as targets for cancer chemoprevention and chemotherapy. Biochimica et Biophysica Acta, v. 1719, n. 1-2, p. 146-160, 2005.

KISSELEVA, T.; UCHINAMI, H.; FEIRT, N.; QUINTANA-BUSTAMANTE, O.; SEGOVIA, J. C.; SCHWABE, R. F.; BRENNER, D. A. Bone marrow-derived fibrocytes participate in pathogenesis of liver fibrosis. Journal of Hepatology, v. 45, n. 3, p. 429-438, 2006.

KNODELL, R. G.; ISHAK, K. G.; BLACK, W. C.; CHEN, T. S.; CRAIG, R.; KAPLOWITZ, N.; KIERNAN, T. W.; WOLLMAN, J. Formulation and application of a numerical scoring system for assessing histological activity in asymptomatic chronic active hepatitis.

Hepatology, v. 1, n. 5, p. 431-435, 1981.

KO, K.; ARORA, P.; LEE, W.; MCCULLOCH, C. Biochemical and functional characterization of intercellular adhesion and gap junctions in fibroblasts. American Journal of Physiology: Cell Physiology, v. 279, p. 147-157, 2000.

KOJIMA, T.; SAWADA, N.; ZHONG, Y.; OYAMADA, M.; MORI, M. Sequential changes in intercellular junctions between hepatocytes during the course of acute liver injury and restoration after thioacetamide treatment. Virchows Archives, v. 425, p. 407-412, 1994.

KOJIMA, T.; FORT, A.; TAO, M.; YAMAMOTO, M.; SPRAY, D. C. Gap junction expression and cell proliferation in differentiating cultures of $\mathrm{Cx} 43 \mathrm{KO}$ mouse hepatocytes. American Journal of Physiology: Gastrointestinal and Liver Physiology, v. 281, n. 4, p. G1004-1013, 2001a.

KOJIMA, T.; KOKAI, Y.; CHIBA, H.; YAMAMOTO, M.; MOCHIZUKI, Y.; SAWADA, N. $\mathrm{Cx} 32$ but not $\mathrm{Cx} 26$ is associated with tight junctions in primary cultures of rat hepatocytes. Experimental Cell Research, v. 263, p. 193-201, $2001 \mathrm{~b}$.

KREMER, A. E.; RUST, C.; EICHHORN, P.; BEUERS, U.; HOLDENRIEDER, S. Immunemediated liver diseases: programmed cell death ligands and circulating apoptotic markers.

Expert Review of Molecular Diagnostics. v. 9, n. 2, p. 139-156, 2009.

KRETZ, M.; EUWENS, C.; HOMBACH, S.; ECKARDT, D.; TEUBNER, B.; TRAUB, O.; WILLECKE, K.; OTT, T. Altered connexin expression and wound healing in the epidermis of connexin-deficient mice. Journal of Cell Science, v. 116, p. 3443-3452, 2003.

KREUZER, H.; MASSEY, A. Engenharia genética e biotecnologia. 2. ed. Porto Alegre: Artmed, 2002. 389 p. 
KUMAR, V.; ABBAS, A. K.; FAUSTO, N.; PERKINS, J. A.; ROBBINS, S. L.; COTRAN, R.S. Patologia - bases patológicas das doenças. 7. ed. Rio de Janeiro: Elsevier, 2005.

KWAK, B. R.; VEILLARD, N.; PELLI, G.; MULHAUPT, F.; JAMES, R. W.; CHANSON, M.; MACH, F. Reduced connexin43 expression inhibits atherosclerotic lesion formation in low-density lipoprotein receptor-deficient mice. Circulation, v. 107, n. 7, p. 1033-1039, 2003.

LEASK, A.; ABRAHAM, D. J. All in the CCN family: essential matricellular signaling modulators emerge from the bunker. Journal of Cell Science, v. 119, p. 4803- 4810, 2006.

LECANDA, F.; WARLOW, P. M.; SHEIKH, S.; FURLAN, F.; STEINBERG, T. H.; CIVITELLI, R. Connexin43 deficiency causes delayed ossification, craniofacial abnormalities, and osteoblast dysfunction. The Journal of Cell Biology, v. 151, n. 4, p. 931944, 2000.

LEE, N. P.; LEUNG, K. W.; WO, J. Y.; TAM, P. C.; YEUNG, W. S.; LUK, J. M. Blockage of testicular connexins induced apoptosis in rat seminiferous epithelium. Apoptosis, v. 11, n. 7, p. 1215-1229, 2006.

LEFTON, H. B.; ROSA, A.; COHEN, M. Diagnosis and epidemiology of cirrhosis. The Medical Clinics of the North America, v. 93, n. 4, p. 787-799, 2009.

LI, D.; FRIEDMAN, S. L. Molecular mechanisms os stellate cell activation and extracellular remodeling. In: OKAZAKI, I.; NINOMIYA, Y.; FRIEDMAN, S. L.; TANIKAWA, K. Extracellular matrix and the liver: approach to gene therapy. Flórida: Academic Press, 2003. p. 155-178.

LI, Z.; ZHOU, Z.; SAUNDERS, M. M.; DONAHUE, H. J. Modulation of connexin43 alters expression of osteoblastic differentiation markers. American Journal of Physiology: Cell Physiology, v. 290, n. 4. p. C1248-1255, 2006.

LIDA, H. V.; SILVA, T. J.; SILVA, A. S.; SILVA, L. F.; ALVES, V. A. F. Cirrose hepática: aspectos morfológicos relacionados às suas possíveis complicações. Um estudo centrado em necropsias. Jornal Brasileiro de Patologia Médica e Laboratorial, v. 41, n. 1, p. 29-36, 2005.

LIM, Y. S.; KIM, W. R. The global impact of hepatic fibrosis and end-stage liver disease.

Clinics in Liver Disease, v. 12, n. 4, p. 733-746, 2008. 
LIM, M. C.; MAUBACH, G.; ZHUO, L. TGF-beta1 down-regulates connexin 43 expression and gap junction intercellular communication in rat hepatic stellate cells. European Journal of Cell Biology, v. 88, n. 12, p. 719-730, 2009.

LIU, X.; HU, H.; YIN, J. Q. Therapeutic strategies against TGF-beta signaling pathway in hepatic fibrosis. Liver International, v. 26, n. 1, p. 8-22, 2006.

LIU, C. L.; HUANG, Y. S.; HOSOKAWA, M.; MIYASHITA, K.; HU, M. L. Inhibition of proliferation of a hepatoma cell line by fucoxanthin in relation to cell cycle arrest and enhanced gap junctional intercellular communication. Chemico-Biological Interactions, v. 182, n. 2-3, p. 165-172, 2009.

LIVAK, K. J.; SCHMITTGEN, T. D. Analysis of relative gene expression data using realtime quantitative PCR and the 2(-Delta Delta C(T)) Method. Methods, v. 25, n. 4, p. $402-$ 408, 2001.

LOEWENSTEIN, W. R.; KANNO, Y. Intercellular communication and the control of tissue growth: lack of communication between cancer cells. Nature, v. 209, n. 5029, p. 1248-1249, 1966.

LOEWENSTEIN, W. R.; ROSE, B. The cell-cell channel in the control of growth. Seminars in Cell Biology, v. 3, n. 1, p. 59-79, 1992.

LU, F.; GAO, J.; OGAWA, R.; HYAKUSOKU, H. Variations in gap junctional intercellular communication and connexin expression in fibroblasts derived from keloid and hypertrophic scars. Plastic and Reconstructive Surgery, v. 119, n. 3, p. 844-851, 2007.

LUSIS, A. J. Atherosclerosis. Nature, v. 407, p. 233-241, 2000.

MA, X. D.; SUI, Y. F.; WANG, W. L. Expression of gap junction genes connexin 32, connexin 43 and their proteins in hepatocellular carcinoma and normal liver tissues. World Journal of Gastroenterology, v. 6, n. 1, p. 66-69, 2000.

MA, X. D.; MA, X.; SUI, Y. F.; WANG, W. L. Expression of gap junction genes connexin 32, connexin $43 \mathrm{mRNAs}$ and proteins, and their role in hepatocarcinogenesis. World Journal of Gastroenterology, v. 8, n. 1, p. 64-68, 2002. 
MAHER, A. C.; THOMAS, T.; RILEY, J. L.; VEITCH, G.; SHAO, Q.; LAIRD, D. W. Rat Epidermal Keratinocytes as an Organotypic Model for Examining the Role of Cx 43 and Cx 26 in Skin Differentiation. Cell Communication and Adhesion, v. 12, p. 219-230, 2005.

MAKOWSKI, L.; CASPAR, D. L.; PHILLIPS, W. C.; GOODENOUGH, D. A. Gap junction structures. II. Analysis of the x-ray diffraction data. The Journal of Cell Biology, v. 74, n. 2, p. 629-645, 1977.

MAN, Y. K.; TROLOVE, C.; TATTERSALL, D.; THOMAS, A. C.; PAPAKONSTANTINOPOULOU, A.; PATEL, D.; SCOTT, C.; CHONG, J.; JAGGER, D. J.; O'TOOLE, E. A.; NAVSARIA, H.; CURTIS, M. A.; KELSELL, D. P. A deafness-associated mutant human connexin 26 improves the epithelial barrier in vitro. Journal of Membrane Biology, v. 218, n. 1-3, p. 29-37, 2007.

MANGNALL, D.; BIRD, N. C.; MAJEED, A. W. The molecular physiology of liver regeneration after partial hepatectomy. Liver international, v. 3, p. 123-138, 2003.

MANUEL, J. A.; GAWRONSKA-KOZAK, B. Matrix Metalloproteinase 9 (MMP - 9) is Upregulated During Scarless Wound Healing in Athymic Nude Mice. Matrix Biology, v. 25, n. 4, p. 505-514, 2006.

MARTYN, K. D.; KURATA, W. E.; WARN-CRAMER, B. J.; BURT, J. M.; TENBROEK, E.; LAU, A. F. Immortalized connexin43 knockout cell lines display a subset of biological properties associated with the transformed phenotype. Cell Growth \& Differentiation, v. 8, p. 1015-1027, 1997.

MARX-STOELTING, P.; MAHR, J.; KNORPP, T.; SCHREIBER, S.; TEMPLIN, M. F.; OTT, T.; BUCHMANN, A.; SCHWARZ, M. Tumor promotion in liver of mice with a conditional Cx26 knockout. Toxicology Sciences, v. 103, n. 2, p. 260-267, 2008.

MEŞE, G.; RICHARD, G.; WHITE, T. W. Gap junctions: basic structure and function. Journal of Investigative Dermatology, v. 127, n. 1, p. 2516-2524, 2007.

MESNIL, M.; CRESPIN, S.; AVANZO, J. L.; ZAIDAN-DAGLI, M. L. Defective gap junctional intercellular communication in the carcinogenic process. Biochimica et Biophysica Acta, v. 1-2, n. 1719, p. 125-145, 2005.

MOREIRA, R. K. Hepatic stellate cells and liver fibrosis. Archives of Pathology \& Laboratory Medicine, v. 131, n. 11, p. 1728-1734, 2007. 
MORI, R.; POWER, K. T.; WANG, C. M.; MARTIN, P.; BECKER, D. L. Acute downregulation of connexin 43 at wound sites leads to a reduce inflammatory response, enhanced keratinocyte proliferation and wound fibroblast migration. Journal of Cell Science, v. 119, p 5193-5203, 2006.

MOYER, K. E.; EHRLICH, H. P. Modulation of human fibroblast gap junction intercellular communication by hyaluronan. Journal of Cellular Physiology, v. 196, n. 1, p. 165-70, 2003.

MURPHY, F. R.; ISSA, R.; ZHOU, X.; RATNARAJAH, S.; NAGASE, H.; ARTHUR, M. J.; BENYON, C.; IREDALE, J. P. Inhibition of apoptosis of activated hepatic stellate cells by tissue inhibitor of metalloproteinase-1 is mediated via effects on matrix metalloproteinase inhibition: implications for reversibility of liver fibrosis. The Journal of Biological Chemistry, v. 13, n. 277, p. 11069-11076, 2002.

NABESHIMA, K.; INOUE, T.; SHIMAO, Y.; SAMESHIMA, T. Advances in matrix metalloproteinases (MMPs), membrane-type MMPs, and a Disintegrin and metallproteinase and their roles in cellular interaction and migration. In: OKAZAKI, I.; NINOMIYA, Y.; FRIEDMAN, S. L.; TANIKAWA, K. Extracellular matrix and the liver: approach to gene therapy. Flórida: Academic Press, 2003. p. 251-275.

NAGASE, H.; VISSE, R.; MURPHY, G. Structure and function of matrix metalloproteinases and TIMPs. Cardiovascular Research, v. 69, n. 3, p. 562-573, 2006.

NAGY, J. I.; HOSSAIN, M. Z.; LYNN, B. D.; CURPEN, G. E.; YANG, S.; TURLEY, E. A. Increased connexin-43 and gap junctional communication correlate with altered phenotypic characteristics of cells overexpressing the receptor for hyaluronic acid-mediated motility. Cell Growth \& Differentiation, v. 7, p. 745-751, 1996.

NAKANO, Y.; OYAMADA, M.; DAI, P.; NAKAGAMI, T.; KINOSHITA, S.;

TAKAMATSU, T. Connexin43 knockdown accelerates wound healing but inhibits mesenchymal transition after corneal endothelial injury in vivo. Investigative

Ophthalmology \& Visual Science, v. 49, n. 1, p. 93-104, 2008.

NAKASE, T.; SÖHL, G.; THEIS, M.; WILLECKE, K.; NAUS, C. C. Increased apoptosis and inflammation after focal brain ischemia in mice lacking connexin43 in astrocytes. American Journal of Pathology, v. 164, n. 6, p. 2067-2075, 2004.

NAKASHIMA, Y.; ONO, T.; YAMANOI, A.; EL-ASSAL, O. N.; KOHNO, H.; NAGASUE, $\mathrm{N}$. Expression of gap junction protein connexin32 in chronic hepatitis, liver cirrhosis, and hepatocellular carcinoma. Journal of Gastroenterology, v. 39, p. 763-768, 2004. 
NAKATA, Y.; IWAI, M.; KIMURA, S.; SHIMAZU, T. Prolonged decrease in hepatic connexin 32 in chronic liver injury induced by carbon tetrachloride in rats. Journal of Hepatology, v. 25, n. 4, p. 529-537, 1996.

NELLES, E.; BUETZLER, C.; JUNG, D.; TEMME, A.; GABRIEL, H. D.; DAHL, U.; TRAUB, O.; STUEMPEL, F.; JUNGERMANN, K.; ZIELASEK, J.; TOYKA, K. V.; DEMIETZEL, R. Defective propagation of signals generated by sympathetic nerve stimulation in the liver of connexin32-deficient mice. Proceedings of the National Academy of Sciences, v. 93, p. 9565-9570, 1996.

NEVEU, M. J.; SATTLER, C. A.; SATTLER, G. L.; HULLY, J. R.; HERTZBERG, E. L.; PAUL, D. L.; NICHOLSON, B. J.; PITOT, H. C. Differences in the expression of connexin genes in rat hepatomas in vivo and in vitro. Molecular Carcinogenesis, v. 11, n. 3, p. 145154, 1994.

NEVEU, M. J.; HULLY, J. R.; BABCOCK, K. L.; VAUGHAN, J.; HERTZBERG, E. L.; NICHOLSON, B. J.; PAUL, D. L.; PITOT, H. C. Proliferation-associated differences in the spatial and temporal expression of gap-junction genes in rat liver. Hepatology, v. 22, p. 202212, 1995.

NICHOLSON, B.; DERMIETZEL, R.; TEPLOW, D.; TRAUB, O.; WILLECKE, K.; REVEL, J. P. Two homologous protein components of hepatic gap junctions. Nature, v. 329, p. 732-734, 1987.

NOVO, E.; DI BONZO, L. V.; CANNITO, S.; COLOMBATTO, S.; PAROLA, M. Hepatic myofibroblasts: a heterogeneous population of multifunctional cells in liver fibrogenesis. The International Journal of Biochemistry and Cell Biology, v. 11, n. 41, p. 2089-2093.

OZDOGAN, M.; ERSOY, E.; DUNDAR, K.; ALBAYRAK, L.; DEVAY, S.; GUNDOGDU, $\mathrm{H}$. Beneficial effect of hyperbaric oxygenation on liver regeneration in cirrhosis. Journal of Surgical Research, v. 129, n. 2, p. 260-264, 2005.

OLORIS, S. C.; MESNIL, M.; REIS, V. N; SAKAI, M.; MATSUZAKI, P.; FONSECA EDE, S.; DA SILVA, T. C.; AVANZO, J. L.; SINHORINI, I. L.; GUERRA, J. L.; COSTA-PINTO, F. A.; MAIORKA, P. C.; DAGLI, M. L. Hepatic granulomas induced by Schistosoma mansoni in mice deficient for connexin 43 present lower cell proliferation and higher collagen content. Life Sciences, v. 80, n. 13, p. 1228-1235, 2007.

OMORI, Y.; DAGLI, M. L. Z.; YAMAKAGE, K.; YAMASAKI, H. Involvement of gap junctions in tumor suppression: analysis of genetically-manipulated mice. Mutation

Research, v. 477, p. 191-196, 2001. 
OKAZAKI, I.; YONEZAWA, T.; WATANABE, T.; MAYNE, R.; NINOMIYA, Y. New insights into the extracellular matrix. In: OKAZAKI, I.; NINOMIYA, Y.; FRIEDMAN, S. L.; TANIKAWA, K. Extracellular matrix and the liver: approach to gene therapy. Flórida: Academic Press, 2003. p. 3-23.

OTT, T.; JOKWITZ, M.; LENHARD, D.; ROMUALDI, A.; DOMBROWSKI, F.; ITTRICH, C.; SCHWARZ, M.; WILLECKE, K. Ablation of gap junctional communication in hepatocytes of transgenic mice does not lead to disrupted cellular homeostasis or increased spontaneous tumourigenesis. European Journal of Cell Biology, v. 85, n. 8, p. 717-728, 2006.

PARADIS, V.; PERLEMUTER, G.; BONVOUST, F.; DARGERE, D.; PARFAIT, B.; VIDAUD, M.; CONTI, M.; HUET, S.; BA, N.; BUFFET, C.; BEDOSSA, P. High glucose and hyperinsulinemia stimulate connective tissue growth factor expression: a potential mechanism involved in progression to fibrosis in nonalcoholic steatohepatitis. Hepatology, v. 34, p. 738-744, 2001.

PARSONS, C. J.; TAKASHIMA, M.; RIPPE, R. A. Molecular mechanisms of hepatic fibrogenesis. Journal of Gastroenterology and Hepatology, v. 22, p. S79-S84, 2007. Supplementum 1.

PROSSER, C. C.; YEN, R. D.; WU, J. Molecular therapy for hepatic injury and fibrosis: where are we? World Journal of Gastroenterology, v. 12, n. 4, p. 509-515, 2006.

QIU, C.; COUTINHO, P.; FRANK, S.; FRANKE, S.; LAW, L.; MARTIN, P.; GREEN, C. R.; BECKER, D. L. Targeting Connexin 43 Expression Accelerates the Rate of Wound Repair. Current Biology, v. 13, p. 1697-1703, 2003.

RACHFAL, A. W.; BRIGSTOCK, D. R. Connective tissue growth factor (CTGF/CCN2) in hepatic fibrosis. Hepatology Research, v. 26, p. 1-9, 2003.

RAMA, A.; MATSUSHITA, T.; CHAROLIDI, N.; ROTHERY, S.; DUPONT, E.; SEVERS, N. J. Up-regulation of connexin43 correlates with increased synthetic activity and enhanced contractile differentiation in TGF-beta-treated human aortic smooth muscle cells. European Journal of Cell Biology, v. 85, n. 5, p. 375-386, 2006.

REAUME, A. G.; DE SOUSA, P. A.; KULKARNI, S.; LANGILLE, B. L.; ZHU, D.; DAVIES, T. C.; JUNEJA, S. C.; KIDDER, G. M.; ROSSANT, J. Cardiac malformation in neonatal mice lacking connexin 43. Science, v. 267, p. 1831-1834, 1995. 
REVEL, J. P.; KARNOVSKY, M. J. Hexagonal array of subunits in intercellular junctions of the mouse heart and liver. The Journal of Cell Biology, v. 33, n. 3, p. C7-C12, 1967.

RODERFELD, M.; HEMMANN, S.; ROEB, E. Mechanisms of fibrinolysis in chronic liver injury (with special emphasis on MMPs and TIMPs). Zeitschrift für Gastroenterologie, v. 45, n. 1, p. 25-33, 2007.

RODRIGUES, A.; DAGLI, M. L. Z.; AVANZO, J. L.; MORAES, H. P.; MACKOWIAK, I. I.; HERNANDEZ-BLAZQUEZ, F. J. Expression and distribution of connexin 32 in rat liver with experimentally induced fibrosis. Pesquisa Veterinária Brasileira, v. 29, p. 353-357, 2009.

RODRÍGUEZ-FRAGOSO, L.; ALVAREZ, R.; REYES-ESPARZA, J. A.; GARCÉS, M. E. Acetaldehyde increases the activity and gene expression of urokinase type plasminogen activator in a hepatic stellate cell line. Toxicology, v. 137, n. 1, p. 1-11, 1999.

SÁEZ, J. C.; BERTHOUD, V. M.; BRANES, M. C.; MARTINEZ, A. D.; BEYER, E. C. Plasma membrane channels formed by connexins: their regulation and functions.

Physiological Reviews, v .83, n. 4, p. 1359-1400, 2003.

SAI, K.; KANG, K. S.; HIROSE, A.; HASEGAWA, R.; TROSKO, J. E.; INOUE, T.; Inhibition of apoptosis by pentachlorophenol in v-myc-transfected rat liver epithelial cells: relation to down-regulation of gap junctional intercellular communication. Cancer Letters, v. 173, n. 2, p. 163-174, 2001.

SAILE, B.; MATTHES, N.; KNITTEL, T.; RAMADORI, G. Transforming growth factor beta and tumor necrosis factor alpha inhibit both apoptosis and proliferation of activated rat hepatic stellate cells. Hepatology, v. 30, n. 1, p. 196-202, 1999.

SANCHES, D. S.; PIRES, C. G.; FUKUMASU, H.; COGLIATI, B.; MATSUZAKI, P.; CHAIBLE, L. M.; TORRES, L. N. ; FERRIGNO, C. R. ; DAGLI, M. L. Z. Expression of connexins in normal and neoplastic canine bone tissue. Veterinary Pathology, v. 46, n. 5, p. 846-859, 2009.

SANTOS, J. A. Tubo digestivo. In: Patologia especial dos animais domésticos (mamíferos e aves). 2. ed. Rio de Janeiro: Guanabara Koogan, 1986. p. 445-473.

SCHEFFER, J. F. S.; GONZÁLEZ, F. H. D. 2006. Enzimologia Clínica em Medicina Veterinária. Disponível em: $<$ http://www6.ufrgs.br/bioquimica/index.htm>. Acesso em: 8 out. 2008. 
SCHUPPAN, D.; RUEHL, M.; SOMASUNDARAM, R.; HAN, E. G. Matrix as modulator of hepatic fibrinogenesis. Seminars in Liver Disease, v. 21, p. 351-372, 2001.

SCHUPPAN, D.; AFDHAL, N. H. Liver cirrhosis. Lancet, v. 371, p. 838-851, 2008.

SEVELIUS, E. Diagnosis and prognosis of chronic hepatitis and cirrhosis in dogs. Journal of Small Animal Practice, v. 33, p. 521-528, 1995.

SILVA, L. C. Hepatite crônica - conceitos. In: GAYOTTO, L. C. C.; ALVES, V. A. F. Doenças do fígado e vias biliares. Rio de Janeiro: Atheneu, 2001. p. 549-552.

SILVA, T. C. Efeitos anti-neoplásicos da raiz de Pfaffia paniculata (Ginseng brasileiro) no modelo de hepatocarcinogênese murina e em cultura de células de hepatocarcinoma humano. 2008. 178 f. Tese (Doutorado em Ciências) - Faculdade de Medicina Veterinária e Zootecnia, Universidade de São Paulo, São Paulo, 2008.

TAKAHARA, T.; YATA, Y.; ZHANG, L. P.; WATANABE, A. Gene expresión of matriz metalloproteinases in acute and chronic liver injuries. In: OKAZAKI, I.; NINOMIYA, Y.; FRIEDMAN, S. L.; TANIKAWA, K. Extracellular matrix and the liver: approach to gene therapy. Flórida: Academic Press, 2003. p. 333-346.

STAINS, J. P.; CIVITELLI, R. Gap junctions in skeletal development and function. Biochimica et Biophysica Acta, v. 1719, n. 1-2, p. 69-81, 2005.

STUTENKEMPER, R.; GEISSE, S.; SCHWARZ, H. J.; LOOK, J.; TRAUB, O.; NICHOLSON, B. J.; WILLECKE, K. The hepatocyte-specific phenotype of murine liver correlates with high expression of connexin 32 and connexin 26 but very low expression of connexin 43. Experimental Cell Research, v. 201, p. 43-54, 1992.

SULKOWSKI, S.; KANCZUGA-KODA, L.; KODA, M.; WINCEWICZ, A.;

SULKOWSKA, M. Insulin-like growth factor-I receptor correlates with connexin 26 and BclxL expression in human colorectal cancer. Annals of the New York Academy of Sciences, v. 1090, p. 265-75, 2006.

TANAKA, M.; GROSSMAN, H. B. Connexin 26 gene therapy of human bladder cancer: induction of growth suppression, apoptosis, and synergy with Cisplatin. Human Gene Therapy, v. 12, n. 18, p. 2225-2236, 2001. 
TEIXEIRA, T. F.; SILVA, T. C.; FUKUMASU, H.; LIMA, C. E.; DAGLI, M. L. Z.; GUERRA, J. L. Histological alteration in the livers of $\mathrm{Cx} 43$-deficient mice submitted to a cholestasis model. Life Sciences, v. 81, n. 5, p. 380-384, 2007.

TEMME, A.; BUCHMANN, A.; GABRIEL, H. D.; NELLES, E.; SCHWARZ, M.; WILLECKE, K. High incidence of spontaneous and chemically induced liver tumors in mice deficient for connexin32. Current Biology, v, 7, n. 9, p. 713-716, 1997.

TEMME, A.; OTT, T.; DOMBROWSKI, F.; WILLECKE, K. The extent of synchronous initiation and termination of DNA synthesis in regenerating mouse liver is dependent on connexin32 expressing gap junctions. Journal of Hepatology, v. 32, n. 4, p. 627-635, 2000.

TEWDT, D. C. Cirrhosis: a consequence of chronic liver disease. Veterinary Clinics of North America: Small Animal Practice, v. 15, p. 151-175, 1985.

THEISS, C.; MAZUR, A.; MELLER, K.; MANNHERZ, H. G. Changes in gap junction organization and decreased coupling during induced apoptosis in lens epithelial and NIH-3T3 cells. Experimental Cell Research, v. 313, p. 38-52, 2007.

THERET, N.; MUSSO, O.; L'HELGOUALC'H, A.; CLEMENT, B. Activation of matrix metalloproteinase-2 from hepatic stellate cells requires interactions with hepatocytes.

American Journal of Pathology, v. 150, p. 51-58, 1987.

TILLMANN, T.; KAMINO, K.; DASENBROCK, C.; KOHLER, M.; MORAWIETZ, G.; CAMPO, E.; CARDESA, A.; TOMATIS, L.; MOHR, U. Quality control of three methods for lung tumorigenesis studies. Experimental and Toxicologic Pathology, v. 51, n. 1, p. 99-104, 1999.

TROSKO, J. E.; RUCH, R. J. Cell-cell communication in carcinogenesis. Frontiers in Biosciences, v. 153, p. d208-d236, 1998.

TROVATO-SALINARO, A.; TROVATO-SALINARO, E.; FAILLA, M.; MASTRUZZO, C.; TOMASELLI, V.; GILI, E.; CRIMI, N.; CONDORELLI, D. F.; VANCHERI, C. Altered intercellular communication in lung fibroblast cultures from patients with idiopathic pulmonary fibrosis. Respiratory Research, v. 27, n. 7, p. 122, 2006.

UENO, T.; SATA, M.; TANIKAWA, K. Cells responsible for extracellular matrix production in the liver. In: OKAZAKI, I.; NINOMIYA, Y.; FRIEDMAN, S. L.; TANIKAWA, K. Extracellular matrix and the liver: approach to gene therapy. Flórida: Academic Press, 2003. p. 89-103. 
UYAMA, N.; SHIMAHARA, Y.; OKUYAMA, H.; KAWADA, N.; KAMO, S.; IKEDA, K.; YAMAOKA, Y. Carbenoxolone inhibits DNA synthesis and collagen gene expression in rat hepatic stellate cells in culture. Journal of Hepatology, v. 39, n. 5, p. 749-755, 2003.

VARGAS, J.; BRENNER, D. A.; PHAN, S. H. Fibrosis research: methods and protocols. New Jersey: Humana Press, 2005. 392 p.

VINKEN, M.; HENKENS, T.; DE ROP, E.; FRACZEK, J.; VANHAECKE, T.; ROGIERS. V. Biology and pathobiology of gap junctional channels in hepatocytes. Hepatology, v. 47, n. 3, p. 1077-1088, 2008.

YAMAOKA, K.; NOUCHI, T.; TAZAWA, J.; HIRANUMA, S.; MARUMO, F.; SATO, C. Expression of gap junction protein connexin 32 and E-cadherin in human hepatocellular carcinoma. Journal of Hepatology, v. 22, p. 536-539, 1995.

YAMAOKA, K.; NOUCHI, T.; KOHASHI, T.; MARUMO, F.; SATO, C. Expression of gap junction protein connexin 32 in chronic liver disease. Liver, v. 20, p. 104-107, 2000.

YAMASAKI, H.; NAUS, C. Role of connexin genes in growth control. Carcinogenesis, v. 17, n. 6, p. 1199-1213, 1996.

YEH, H. I.; DUPONT, E.; ROTHERY, S.; COPPEN, S. R.; SEVERS, N. J. Individual gap junction plaques contain multiple connexins in arterial endothelium. Circulation Research, v. 83, p. 1248-1263, 1998.

ZAIDAN-DAGLI, M. L.; HERNANDEZ-BLAZQUEZ, F. J. Roles of Gap junctions and connexins in non-neoplastic pathological processes in which cell proliferation is involved. Journal of Membrane Biology, v. 218, p. 79-91, 2007.

ZEISBERG, M.; HANAI, J.; SUGIMOTO, H.; MAMMOTO, T.; CHARYTAN, D.; STRUTZ, F.; KALLURI, R. BMP-7 counteracts TGF-beta1-induced epithelial-tomesenchymal transition and reverses chronic renal injury. Nature Medice, v. 9, n. 7, p. 964968,2003

ZEISBERG, M.; YANG, C.; MARTINO, M.; DUNCAN, M. B.; RIEDER, F.; TANJORE, H.; KALLURI, R. Fibroblasts derive from hepatocytes in liver fibrosis via epithelial to mesenchymal transition. The Journal of Biological Chemistry, v. 282, n. 32, p. 23337 23347, 2007. 
ZHANG, M.; THORGEIRSSON, S. S. Modulation of connexins during differentiation of oval cells into hepatocytes. Experimental Cell Research, v. 213, p. 37-42, 1994.

ZHANG, L. P.; TAKAHARA, T.; YATA, Y.; FURUI, K.; JIN, B.; KAWADA, N.;

WATANABE, A. Increased expression of plasminogen activator and plasminogen activator inhibitor during liver fibrogenesis of rats: role of stellate cells. Journal of Hepatology, v. 31, n. 4, p. 703-711, 1999.

ZHANG, Y.; KANTER, E. M.; LAING, J. G.; APRHYS, C.; JOHNS, D. C.; KARDAMI, E.; YAMADA, K. A. Connexin43 expression levels influence intercellular coupling and cell proliferation of native murine cardiac fibroblasts. Cell Communication \& Adhesion, v. 15, n. 3, p. 289-303, 2008.

WATSON, P. J. Chronic hepatitis in dogs: a review of current understanding of the aetiology, progression, and treatment. The Veterinary Journal, v. 167, p. 228-241, 2004.

WEIBEL, E. R. Stereological methods: pratical methods for biological morphometry. Londres: Academic Press, 1989. 415 p.

WAGGETT, A. D.; BENJAMIN, B.; RALPHS, J. R. Connexin 32 and 43 gap junctions differentially modulate tenocyte response to cyclic mechanical load. European Journal of Cell Biology, v. 85, p. 1145-1154, 2006.

WANG, T. W.; WU, H. C.; HUANG, Y. C.; SUN, J. S.; LIN, F. H. The effect of selfdesigned bifunctional RGD-containing fusion protein on the behavior of human keratinocytes and dermal fibroblasts. Journal of Biomedical Materials Research part B: Applied Biomaterials, v. 79, n. 2, p. 379-387, 2006.

WILLECKE, K.; HENNEMANN, H.; DAHL, E.; JUNGBLUTH, S.; HEYNKES, R. The diversity of connexin genes encoding gap junctional proteins. European Journal of Biology, v. 56, n. 1, p. 1-7, 1991.

WOOD, G. A.; SARMA, D. S. R.; ARCHER, M. C. Resistance to the promotion of glutathione S-transferase 7-7-positive liver lesions in Copenhagen rats. Carcinogenesis, London, v. 20, n. 7, p. 1169-1175, 1999.

WRIGHT, C. S.; VAN STEENSEL, M. A.; HODGINS, M. B.; MARTIN, P. E. Connexin mimetic peptides improve cell migration rates of human epidermal keratinocytes and dermal fibroblasts in vitro. Wound Repair and Regeneration, v. 17, n. 2, p. 240-249, 2009. 
WYNN, T. A. Common and unique mechanisms regulate fibrosis in various fibroproliferative diseases. The Journal of Clinical Investigation, v. 117, n. 3, p. 524-529, 2007. 